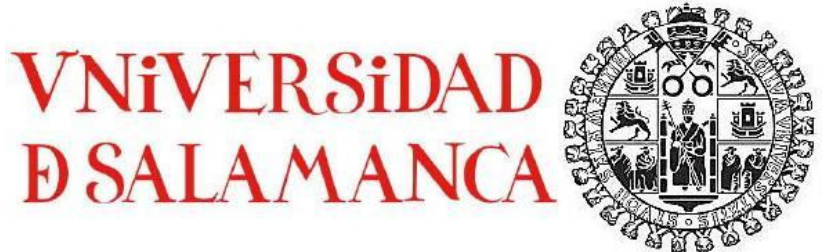

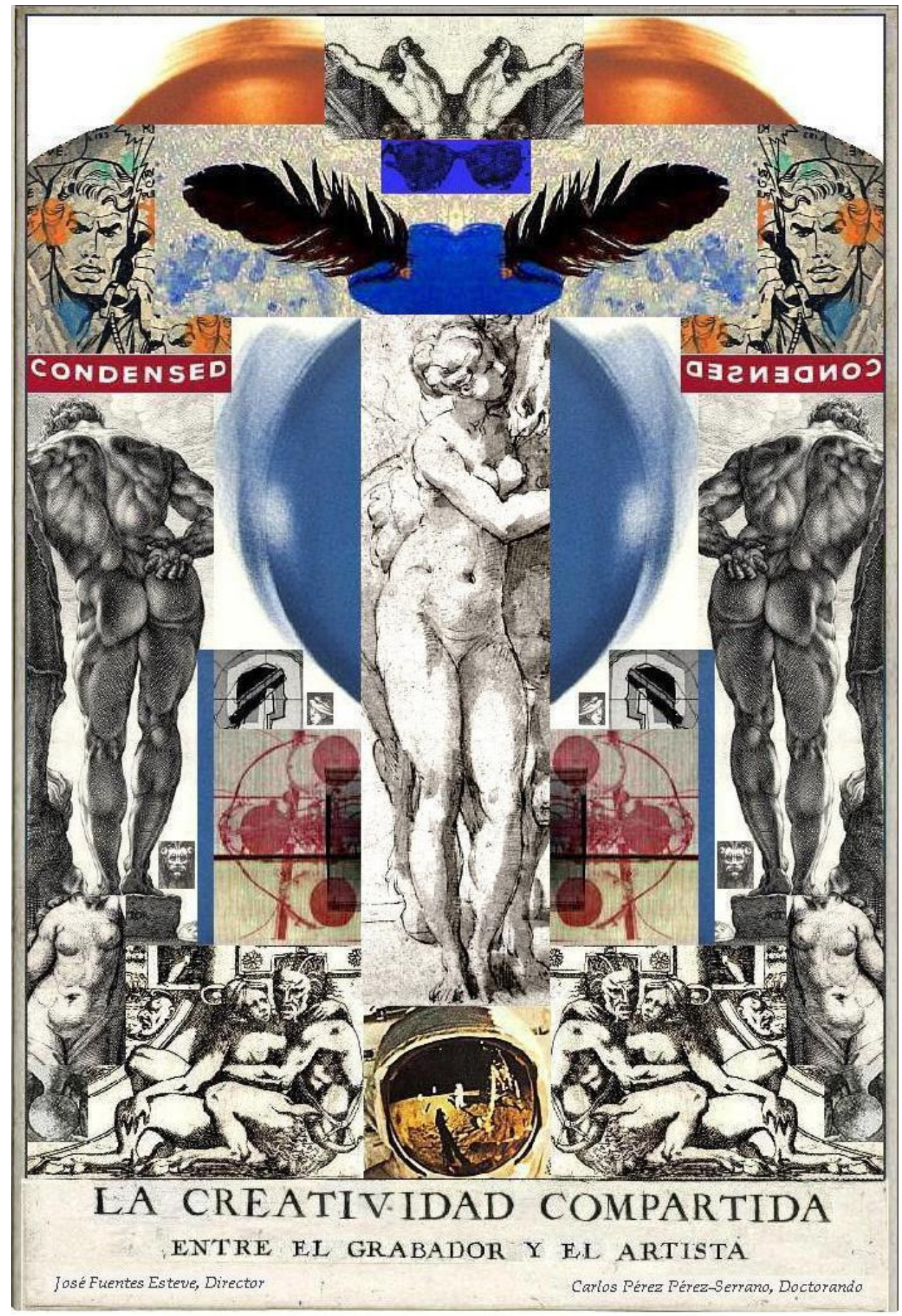

TESIS DOCTORAL

Facultad de Bellas Artes. Departamento de Historia del Arte / Bellas Artes. 
Tesis Doctoral

\section{LA CREATIVIDAD COMPARTIDA ENTRE EL GRABADOR Y EL ARTISTA}

\section{Carlos Enrique Pérez Pérez-Serrano}

Director: José Fuentes Esteve

Universidad de Salamanca. Facultad de Bellas Artes. Departamento de Historia del Arte / Bellas Artes.

Curso académico: 2010- 2011.

Salamanca, Junio de 2011. 


\section{Director de la Tesis Doctoral:}

\section{José Fuentes Esteve}

Catedrático de Dibujo de la Facultad de Bellas Artes. Universidad de Salamanca.

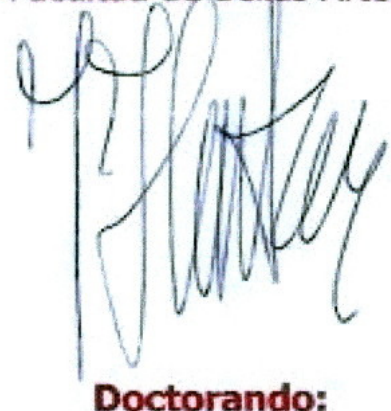

\section{Carlos Enrique Pérez Pérez-Serrano}

Licenciado en Historia del Arte por la Facultad de Geografía e Historia.

Universidad de Salamanea.

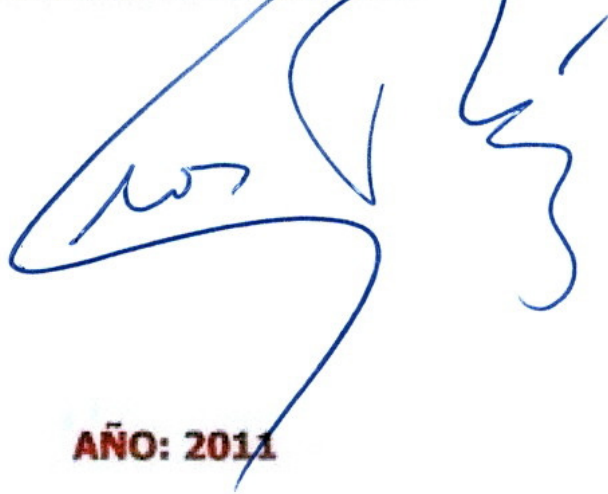




\section{Agradecimientos}

A Pepe Fuentes por ayudarme a ordenar las ideas y en muchos casos inspirarlas con sus conocimientos y su enorme experiencia. A Concha Sáez por su entusiasmo y la claridad contagiosa de sus actos y sus afectos. A Maria Reina Salas, la primera en Salamanca y en mi corazón de amigo. A Concha Jerez por su sabiduría y todos esos amaneceres sobre ruedas. A todos ellos, artistas y docentes, por su ejemplar profesionalidad y su cariño sincero.

Este trabajo está dedicado a Miguel Pedrazo, por darme todas sus horas y su alegría. 
ÍNDICE.

\section{I.- CATEGORÍAS Y GRADO DE COLABORACIÓN} ENTRE EL ARTISTA Y EL TÉCNICO GRABADOR

\section{II.- ESTUDIOS HISTÓRICOS.}

II-1: Categorización de los artistas y grabadores históricos.

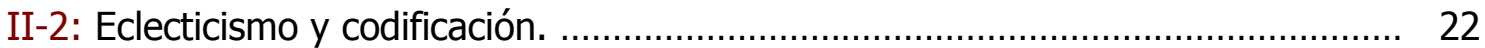

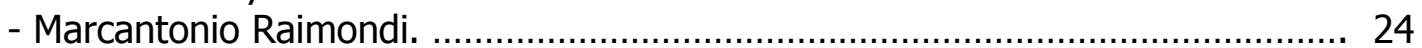

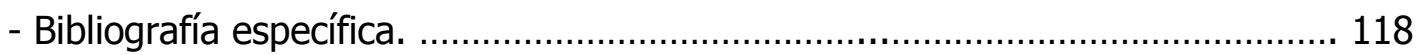

II-3: Una experiencia completa ................................................................... 120

- La Escuela de Grabado de Fontainebleau. .................................................... 122

- Bibliografía específica. .................................................................................. 231

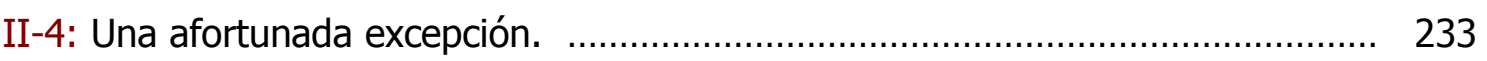

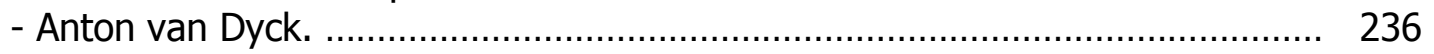

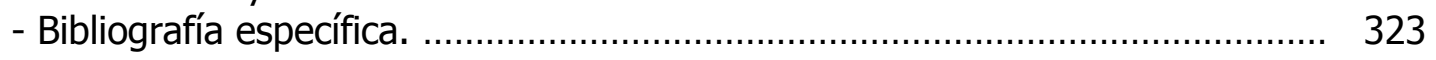

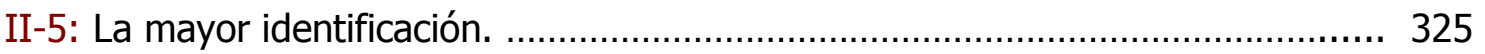

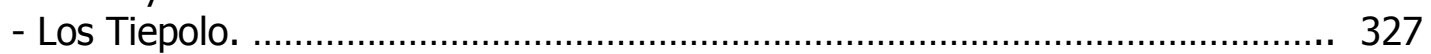

- Bibliografía específica. .................................................................... 382

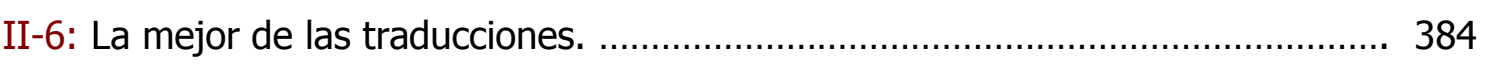

- John Constable, pintor y David Lucas, grabador. ..................................... 387

- Bibliografía específica. ............................................................................. 416

II-7: El cambio de mentalidad. ….................................................................. 418

- Estados Unidos (1960.1990). ............................................................ 421

- Bibliografía específica. ...................................................................... 492

\section{III.- ESTUDIOS DE LAS EXPERIENCIAS PROFESIONALES PROPIAS.}

III-1: Categorización de los artistas y de las obras creadas en colaboración. .......... 494

III-2: Colaboración Libre (Primer Supuesto). ................................................... 498

- Realización de seis grabados del artista Luís Gordillo. ................................. 501

- Bibliografía específica. ............................................................................... 513

- Realización de tres grabados del artista Pablo Márquez. .............................. 515

- Bibliografía específica. ............................................................................... 525 
III-3: Condicionamiento Superficial (Segundo Supuesto). ................................... 526

- Realización de dos grabados de la artista Elena Blasco.............................. 527

- Bibliografía específica. ............................................................................. 533

- Realización de diez grabados del artista Antón Lamazares.......................... 534

- Bibliografía específica. ............................................................................. 546

- Realización de un grabado del artista Bernardo Tejeda. .............................. 547

- Bibliografía específica. ............................................................................... 552

III-4: Condicionamientos Reelaborados (Tercer Supuesto). ................................... 553

- Realización de doce grabados del artista Ángel Haro. .................................... 554

- Bibliografía específica. ................................................................................. 559

- Realización de un grabado del artista Luís Moscardó. .................................... 560

- Bibliografía específica. ................................................................................... 566

- Realización de cuatro grabados del artista Bernardo Tejeda. ....................... 567

III-5: Colaboración Parcial (Cuarto Supuesto). ........................................................ 574

- Realización de dos grabados del artista César Galicia. .................................. 575

- Bibliografía específica. ........................................................................ 585

III-6: Técnicas y recursos empleados en los procesos de ejecución. ................... 586

\section{IV.- LA COLABORACIÓN CREATIVA EN EL ÁMBITO EDUCATIVO.}

IV-1: Claves de colaboración entre el grabador docente y el alumno. ..................... 592

IV-2: Análisis de los aspectos esenciales del proceso formativo. ............................. 596

IV-2.1: Asesoramiento en el planteamiento creativo de la idea................................596

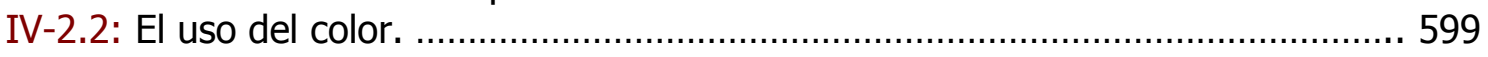

IV-3: Documentación formativa de los procesos técnicos. ....................................6 608

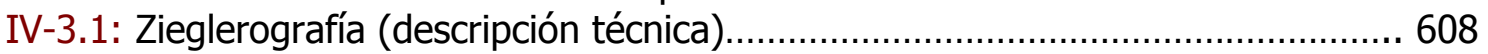

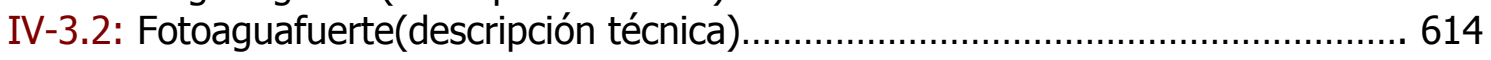

IV-4: Alteraciones a la Prueba de Estado: La Imagen Mixta. ................................ 622

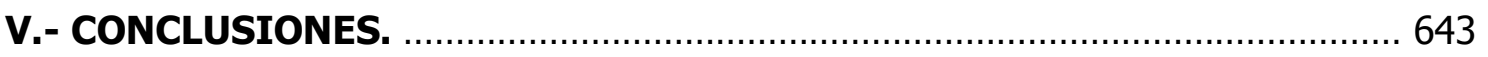

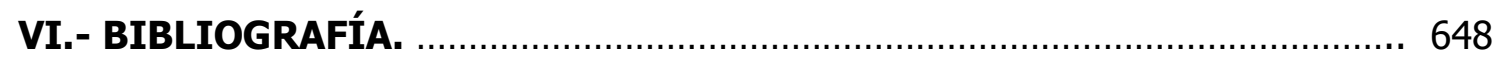




\section{INTRODUCCIÓN}

Desde su aparición en occidente, paralelo al de la imprenta, el grabado se ha movido como medio de expresión artística entre dos extremos. En uno de ellos se desarrollará como técnica reproductora de imágenes creadas previamente mediante otra técnica, pintura, escultura o dibujo, que gracias a la cualidad que el grabado tiene para multiplicar sus resultados en un número grande de ejemplares, servirá para difundirlas atendiendo a intereses comerciales, ideológicos o políticos. En el otro extremo nos encontramos con el grabado de pura creación, aquel en que un artista experto en las peculiaridades de estas técnicas e interesado por lo que las caracteriza y diferencia del resto de los medios de expresión plástica, hace uso de ellas para crear imágenes originales que ofrecen la posibilidad de poder ser seriadas.

La difusión mediante la estampa del Renacimiento inicia el uso del grabado reproductivo como vehículo de autores y logros artísticos que en la historia del arte no dejará de existir hasta que la aparición de la fotografía lo haga innecesario para ese fin. Autores conocedores del medio como Durero, Rembrandt o Goya, lo usarán como vehículo de expresión autónomo, planteando una obra creada por y para este medio en exclusiva e independiente de sus demás facetas creativas.

Pero el grabado precisa de un prolongado aprendizaje y unas infraestructuras técnicas especializadas y complejas que no han poseído la gran mayoría de los artistas que a lo largo de la historia han estado interesados en producir estampas. Es ahí donde se produce un hecho diferenciador entre el grabado y las demás artes. Los impulsos creativos de un artista no iniciado necesitan de la colaboración de un técnico grabador especializado para tomar forma.

La técnica del grabado ofrece una dificultad añadida al proceso de creación. Dibujo, pintura o escultura son técnicas inmediatas, de mayor o menor extensión temporal en su desarrollo, pero directas. La construcción del objeto artístico avanza linealmente de principio a fin y por muchas vacilaciones, correcciones o variaciones que se incluyan en ese camino, es la mano del artista la que inicia y ultima la obra sin alteraciones en el proceso que lleva desde la concepción a la planificación y finalmente a la ejecución de un trabajo de creación artística.

En el grabado no ocurre lo mismo, la creación de una estampa y la edición de una serie de ellas implica la construcción de matrices permanentes. Ya sean estas de madera, metal, o cualquier otro material susceptible de soportar la enorme presión que el tórculo ejerce en el proceso de impresión, ellas son el medio a través del cual transita la obra desde la cabeza hasta el papel.

La elaboración de las matrices o planchas de grabado es un proceso intermedio, no es el objetivo final del trabajo creativo, mediante su realización estamos creando un instrumento que es la principal vía de transmisión entre la idea y el resultado, un vehículo de transporte entre los pensamientos y las imágenes resueltas. Al gran número de técnicas tradicionales para conseguir todo tipo de resultados que la historia nos aporta, hay que añadir el trabajo experimental que el profesional del grabado desarrolla en su taller. 
Las peculiaridades que tienen los materiales con que se construyen las matrices y las de los útiles con que se trabajan, las reacciones de las sustancias químicas con que se atacan, las características de lacas y barnices con los que se protegen, forman un bloque de conocimientos de aspectos complejos que exige para su dominio un largo tiempo de aprendizaje y trabajo experimental.

Todo esto implica un traslado indirecto entre aquello que se idea y los resultados. La fuerza de la idea primera se tiene que mantener durante el proceso, tiene que sustentarse sobre un objeto fabricado, la matriz, que sometida a otras labores intermedias, entintado, limpieza y estampación, materializará aquello que se intuyó en un objeto concreto, la estampa. Imagen impresa sobre un soporte flexible que absorba tinta, generalmente papel.

La experiencia adquirida con la práctica profesional de estos procesos genera una forma de ver las cosas, de acometer las obras y una cierta previsión para anticipar los resultados. Se comprenderá así que salvo en el caso de los artistas grabadores, la creación de obra gráfica por parte de cualquier otro artista sin toda la experiencia necesaria específica del grabado, o sin ninguna en absoluto, exija forzosamente una colaboración interdisciplinar. De la calidad particular de cada uno de los colaboradores y del grado de identificación entre ambos, dependerá el valor de los resultados obtenidos.

Esta tesis doctoral pretende demostrar que cuando se aborda un trabajo de colaboración entre un artista y un técnico grabador para crear una estampa o una serie de ellas, se está produciendo una colaboración creativa única y que por lo tanto ese acto de creación es compartido entre ambos. Que la parte que le corresponde en el resultado al grabador es esencial y tan importante como la que le corresponde al artista y que esto es una realidad injustamente silenciada a lo largo de la historia, especialmente durante el último siglo en el mundo artístico y más en el español, por la ignorancia de la realidad del proceso de creación en grabado, motivos comerciales y una ideología trasnochada que solo consagra la imagen del artista-genio, sin valorar la realidad del trabajo y la responsabilidad de sus ejecutores.

Para fundamentar este razonamiento se proponen tres campos de estudio y análisis. El histórico, el derivado de mi experiencia personal como grabador profesional y asesor creativo en la edición de estampas y el de mi experiencia como docente universitario en el campo del grabado y la estampación.

Con estos estudios se pretenden establecer una serie de categorías o supuestos de colaboración creativa entre artista y grabador según el grado de implicación de cada uno de ellos en el acto de creación compartida de las obras o series gráficas.

En el análisis histórico se exponen los procesos de creatividad compartida entre artistas y grabadores en seis momentos especialmente interesantes de la historia del grabado y determinantes por su trascendencia inmediata y su influencia sobre el posterior desarrollo del medio. Marcantonio Raimondi y su escuela romana de grabadores, la escuela de grabadores de Fontainebleau, Antón van Dyck, Giambattista, Giandomenico y Lorenzo Tiepolo, John Constable y David Lucas y el periodo comprendido entre los años 1960 y 1990 en la creación de obra gráfica en Estados Unidos. 
Es de mi interés que en esta tesis lo visual se presente con la mayor importancia y para ello he recurrido a la búsqueda, selección y análisis de un número grande de imágenes significativas pertenecientes a cada periodo, a la elaboración de cuadros detallados que presenten las grafías y estilos de ejecución característicos de cada autor y en la medida de lo posible al rastreo de los bocetos y obras de otro origen de los que derivan las estampas, estableciendo comparaciones que permitan valorar resultados con un criterio más firme.

Aún en el caso del grabado meramente reproductivo la apreciación de los resultados merece una especial matización. Siempre hay algo que reseñar, la aplicación de los recursos técnicos correctos y el grado de sensibilidad al ponerse al servicio de una imagen y de una idea preexistentes, deben ser reconocidos y esto es algo que necesita de la explicación de los complejos procesos necesarios. Aunque sea en pequeña medida, la creatividad está también presente desde el momento en que el responsable de la existencia de cualquier estampa es un individuo formado para realizarla y no una máquina.

Para la elaboración del apartado que analiza las obras ejecutadas en colaboración entre mi persona y una serie de artistas en las últimas dos décadas, he procedido a la recopilación del material existente que da testimonio de los distintos procesos realizados. Estampas, bocetos y matrices han sido fotografiados y se han detallado fragmentos que ofrecen aspectos importantes de estos para definir con claridad sus planteamientos y el modo de actuar que condujo a los resultados concretos que se muestran. La narración de cada uno de los procesos pretende categorizar las experiencias vividas en cuatro principales supuestos de colaboración. Las experiencias particulares que se analizan en el desarrollo de este trabajo, proceden del conocimiento directo. Tanto como asistente y posteriormente socio de un taller de reconocido prestigio, el del grabador hispano argentino Oscar Manesi, como en mi propio taller de edición, grabado y estampación, he asistido a todos y cada uno de los procesos reseñados en primera persona.

El acceso directo a las estampas que ilustran este estudio y a muchas de las matrices que no fueron destruidas tras realizarse la edición, ha ayudado a que las descripciones sean todo lo pormenorizadas y exactas posible. Las cualidades visuales de una estampa, sutiles pero muy expresivas, son imposibles de reproducir con total fidelidad en fotografía. Aún siendo la bidimensionalidad en grabado su espacio natural, las cualidades especificas de color, textura y reflejo de la luz que las tintas impresas ofrecen sobre el papel tras la impresión son inigualables y su observación directa ayuda a reflejar con precisión el esfuerzo que fue necesario acometer para obtener los resultados que aquí se presentan, sobre todo en el caso de aquellos ejemplos cuya ejecución se aleja más en el tiempo.

Para el capítulo en el que se argumenta sobre la importancia del conocimiento de los precedentes históricos y de la experiencia adquirida en los años de práctica profesional para la docencia de los procesos del grabado dentro del marco del Espacio Europeo de Educación Superior, me he centrado en los contenidos de una de las asignaturas que imparto en la Facultad de Bellas Artes de la Universidad de Salamanca, "La imagen múltiple y procesos de la obra gráfica", elaborando un material de utilidad divulgativa y docente que analiza los procesos técnicos y los aspectos teóricos implicados en la enseñanza de esta asignatura concreta. 
Una selección de obras creadas por los alumnos de segundo ciclo que han cursado esta asignatura desde el año 2001 hasta nuestros días, ha sido fotografiada y analizada. He creado esquemas visuales para ilustrar las descripciones de procesos técnicos y aspectos teóricos imprescindibles para la ideación, ejecución y obtención de los mejores resultados, con el objetivo fundamental de que esos resultados alcanzaran el mayor de los niveles artísticos posibles en la carrera de los alumnos, creadores en formación.

No es ajena a los objetivos de esta tesis doctoral una reivindicación común entre los profesionales del grabado. Existe un relativo desconocimiento general sobre los procesos necesarios para la creación de una estampa. La confusión entre el trabajo que supone la realización de una obra gráfica original, seriada o no, y aquella que se reproduce de forma puramente mecánica, exige aclaraciones que este trabajo pretende dar. La apreciación de las imágenes y de las técnicas que las han hecho posibles es una intención que como profesional del medio y como admirador de la obra artística siempre tengo presente, transmitir y explicar esa intención también forma parte de mis objetivos al abordar este trabajo. 


\section{I: Categorías y Grado de Colaboración entre el Artista y el Técnico Grabador.}

Al analizar las relaciones que se establecen al producirse la colaboración entre un técnico grabador y un artista de otra disciplina ajena al mundo del grabado, he encontrado una significativa variedad de maneras de acometer el trabajo de creación en la obra gráfica. Estas circunstancias variables hicieron necesaria una estructuración que permitiera una análisis comparativo riguroso, orientado a demostrar la hipótesis que mi tesis plantea, es decir, a despejar las dudas sobre que es lo que ocurre cuando dos individuos, el artista y el técnico grabador, comparten la producción de una misma obra.

Al analizar los casos concretos que en esta tesis se presentan, llegué al convencimiento de que era imprescindible la creación de un esquema gráfico que abarcara todos los aspectos y variables presentes en el amplio número de casos estudiados y de este modo poner en claro mediante un análisis comparado, las distintas circunstancias en que se establecen las relaciones profesionales entre el artista y el técnico grabador.

Esta estructura resulta reveladora ya que ayuda a entender como la alteración de un solo factor de los contemplados, nos conduce a una forma significativamente distinta de relación y por lo tanto de colaboración creativa. En el desarrollo de los siguientes capítulos, analizaré cada uno de los casos elegidos y las implicaciones de los personajes esenciales de estos estudios: artistas y grabadores.

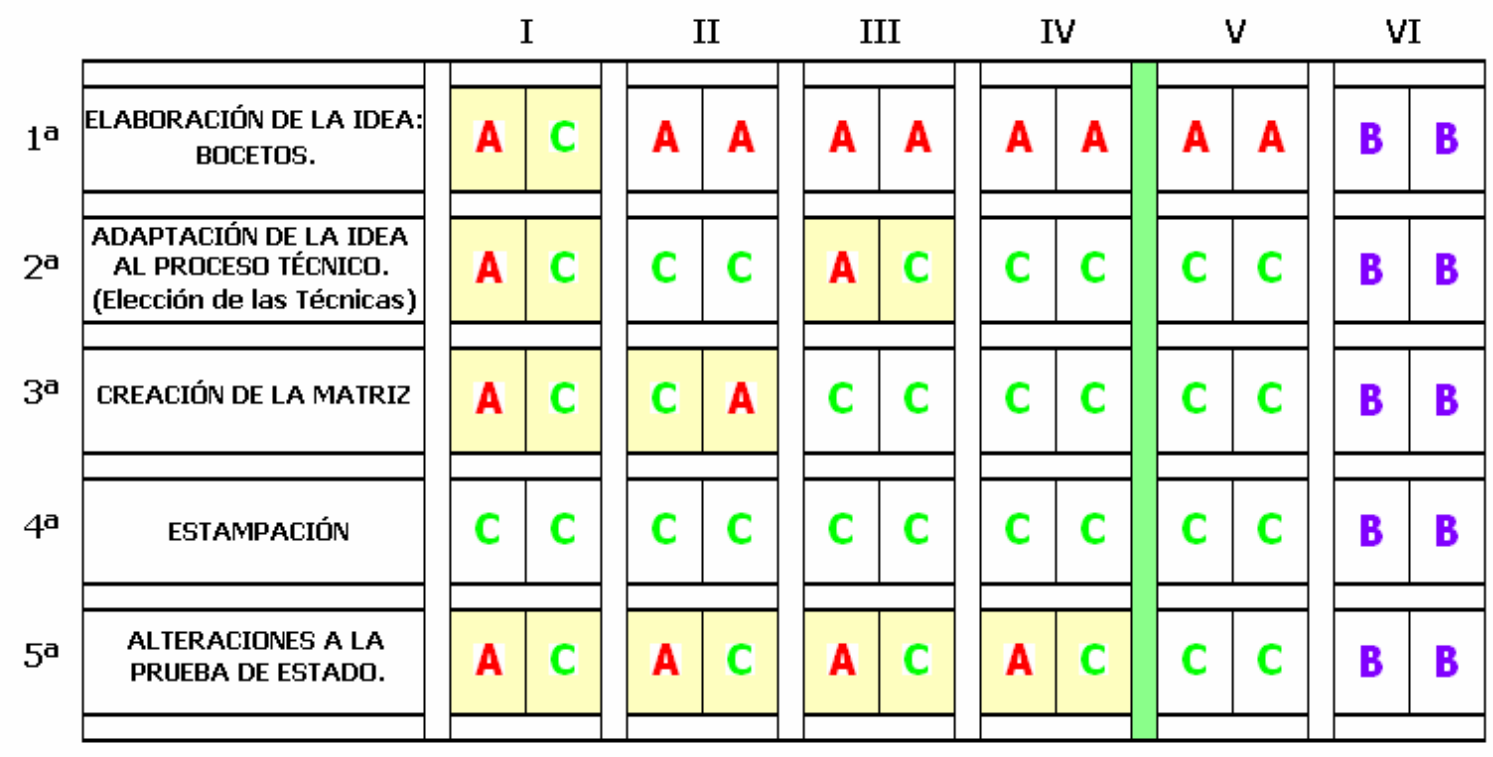

I.- Libre Colaboración

II.- Condicionamiento Superficial

A.- Artista

III.- Condicionamientos Reelaborados

B.- Artista Grabador

C.- Técnico Grabador

IV.- Colaboración Parcial

V.- Grabador Reproductor

VI.- Artista Grabador

Creatividad Compartida

CATEGORÍAS Y GRADO DE COLABORACIÓN EN LAS ETAPAS DE CREACIÓN DE LA IMAGEN GRABADA 
Los ejes del cuadro gráfico relacionan las seis categorías en que he dividido las formas de colaborar en la creación de una estampa, con las cinco etapas necesarias para hacerlo. Situando en las intersecciones las figuras del artista A y del técnico grabador C, observamos que su acción conjunta se sitúa de un modo u otro dependiendo de las circunstancias particulares de cada caso. En paralelo al cuadro en que se producen supuestos de creación compartida (I al IV), también contemplo los casos del grabado meramente reproductivo (V), y del creado por un individuo en solitario (VI), el artista grabador B, aunque en ambos circunstancias no se produzca colaboración creativa alguna.

-Fases esenciales en el desarrollo de una imagen en grabado: Son aquellas indispensables para la creación de una estampa susceptible de ser seriada.

$1^{\text {a) }}$ Elaboración de la idea: bocetos.

$2^{a}$ ) Adaptación de la idea al proceso técnico, (elección de las técnicas).

$3^{a}$ ) Creación de la matriz.

4a) Estampación.

5a) Alteraciones a la Prueba de Estado.

El análisis de cada uno de estos pasos nos dará la clave de su significado en el desarrollo de proceso creativo de la obra gráfica.

\section{1a) Elaboración de la idea: bocetos.}

En el proceso de creación de la imagen múltiple es necesario partir de una imagen preexistente, ya elaborada por completo en otra técnica o de una idea original a partir de la cual se elaboren los bocetos pertinentes. Tanto en uno como en otro caso, la naturaleza de esa obra o de esa idea ya abocetada dará lugar a una interpretación en clave gráfica para convertirla en otra obra capaz de ser seriada, multiplicada. La imagen ya existente tomada como punto de partida puede ser de variable complejidad, desde un edificio, una pintura de gran formato o una pieza escultórica, hasta un dibujo sencillo, una acuarela o un óleo de tamaño menor. Igual ocurre con los bocetos realizados a partir de una idea específica para ser trasladada a la condición de estampa múltiple, pueden ser muy analíticos y ultimados o muy esquemáticos. Las condiciones del objeto del que partimos serán de enorme importancia para el desarrollo posterior del proceso, puesto que determinarán las técnicas más adecuadas a utilizar.

\section{$2^{a}$ ) Adaptación de la idea al proceso técnico, (elección de las técnicas).}

Las decisiones que se tomen en esta fase serán de una importancia determinante en los resultados, ya que obligan a definir la naturaleza del código gráfico con que se representará la imagen que queremos convertir en matriz permanente. Que elementos, o que conjunto de ellos, serán los que conformen la imagen: los distintos tipos de línea, de mancha, de textura, etc. Si la obra se resolverá en clave de claroscuro o será el color su protagonista.... . Actuando en consecuencia con lo calibrado como más beneficioso para el resultado final, se elegirán las técnicas adecuadas. Acto éste progresivamente más complejo en el transcurso de la Historia del Grabado, desde el número limitado de técnicas en los orígenes hasta la gran variedad y complejidad de éstas y de los nuevos materiales que nos ofrece el grabado contemporáneo. 


\section{$\left.3^{a}\right)$ Creación de la matriz.}

Paso este esencial en el proceso de creación de la obra gráfica, ya que nos proporciona el vehículo físico que hará posible convertir lo preexistente o ideado en una imagen múltiple susceptible de ser repetida y seriada. Este punto del proceso es esencialmente técnico y por lo tanto condicionado a que su realización sea debida a alguien con un profundo conocimiento del medio. Como en algunos supuestos este conocimiento no es dominado por el artista, su relación con el técnico grabador produce diferentes circunstancias que se analizarán en los siguientes capítulos.

\section{4a) Estampación.}

Es este un proceso singular dentro del planteamiento general de una obra gráfica. Ejecutado generalmente por un especialista, el estampador, diferente al técnico grabador y al artista, su importancia es tal que de una buena matriz se obtendrán resultados mediocres debido a una estampación deficiente y por el contrario, un buen estampador puede conseguir grandes resultados de una matriz mal realizada. El técnico grabador ha de actuar como estampador óptimo al menos hasta la consecución de la prueba final, la B.A.T. (bonne à tirer), aquella que servirá de muestra para seriar la edición de grabado. En algunas ocasiones actuará él mismo como estampador y siempre como supervisor de las estampas obtenidas. Utilizando los diferentes recursos del proceso de estampación, sobreimpresiones, desplazamiento, encolados, etc., se pueden añadir a la estampa elementos gráficos que no estén presentes en la matriz permanente y estas decisiones han de ser tomadas o bien previamente, en el paso segundo en que se han elegido las técnicas adecuadas, o sobre la marcha si es que se está actuando con un grado de libertad suficiente como para variar en parte el boceto o la imagen previa del que la obra gráfica parte.

\section{5a) Alteraciones a la prueba de estado.}

Aquellas que han de llevar a la consecución total de los objetivos planteados inicialmente. Pueden ser de índole meramente técnica en el caso de que se haya partido de una imagen preexistente que se quiera llevar fielmente a la estampa o que tenga su origen en un boceto extremadamente analítico y ultimado. También puede ocurrir que las decisiones que sobre la prueba de estado se tomen sean de importancia estética en el resultado final, que conduzcan a la alteración de alguno de los pasos previos para conseguir unos resultados diferentes a los intuidos o previstos y que enriquezcan el trabajo realizado. El distinto grado de participación en estas decisiones, dará lugar a variables que también se contemplan en los análisis particulares de los capítulos siguientes.

-Supuestos de colaboración en la creación compartida de la obra gráfica: En el esquema gráfico creado, el eje horizontal está dividido en seis apartados que representan las diferentes formas de colaboración entre artista y técnico grabador. Cualquier de los supuestos analizados en los estudios particulares realizados para esta tesis encaja a la perfección en uno de ellos. 


\section{I) Libre Colaboración. \\ II) Condicionamiento Superficial. \\ III) Condicionamientos Reelaborados. \\ IV) Colaboración Parcial.}

\section{V) Grabador Reproductor. \\ VI) Artista Grabador.}

Las cuatro primeras categorías responden a la colaboración entre artista y técnico en una o más de las fases de creación de una obra. Cada una de ellas se ha planteado a partir de la síntesis de los numerosos ejemplos de relaciones y obras analizadas.

\section{I) Libre Colaboración.}

Aquella en que los dos profesionales, el artista y el técnico grabador, inician sin condicionamiento alguno el proceso de creación de una estampa o una serie de ellas, desde los planteamientos iniciales, las ideas, hasta las alteraciones finales de la prueba de estado. El interés profesional mutuo, basado en las capacidades de cada uno de los componentes del tandem artista-grabador, el conocimiento por parte del artista del medio gráfico en mayor o menor medida, o en muchas ocasiones la amistad personal, hacen que en esta categoría se comparta la responsabilidad en todas las fases de la creación, exceptuando la estampación de las matrices (aunque podríamos contemplar excepciones: por ejemplo, un grabado a dos planchas estampado entre un artista entrenado en la técnica y el grabador).

\section{II) Condicionamiento Superficial.}

Cuando las condiciones de libertad creativa y confianza mutua se ven ligeramente condicionadas por terceras personas, el editor generalmente, que impone alguna condición en el proceso creativo, por ejemplo el formato, sin inmiscuirse en el resto de las facetas creativas y técnicas del proyecto. La intención del agente externo que condiciona, ha de ser que de la colaboración entre artista y técnico se obtengan los resultados que la libertad total de actuación transmite a los resultados. Es entonces el proceso muy cercano al que se plantea en el supuesto primero de esta clasificación.

\section{III) Condicionamientos reelaborados.}

Con frecuencia en la colaboración entre grabador y artista se parte de imágenes que están ya elaboradas. Si a pesar de ello es voluntad del artista que la traducción al lenguaje específico del grabado origine un resultado distinto al de la imagen inicial, se plantearán una serie de alternativas y aspectos del proceso en los que la colaboración se impone como indispensable para obtener resultados valiosos. La alteración de aspectos presentes en el objeto artístico inicial en función de las posibilidades que las técnicas de grabado ofrecen darán como resultado estampas inspiradas por algo preexistente pero con características propias y únicas, por su cualidad de obra gráfica original seriada.

\section{IV) Colaboración Parcial.}

En el caso de que la imagen inicial de la que partimos está resulta en su totalidad, el 
grado de colaboración creativa se reduce considerablemente pero no queda excluido por completo. El aspecto de la ideación pertenece en exclusiva al artista, la elección de las técnicas idóneas, la creación de la matriz y la estampación, al técnico grabador. Pero durante el proceso el diálogo ha de ser una constante si queremos los mejores resultados y en la fase final, la de las alteraciones a la prueba de estado las decisiones, sin duda creativas, han de ser compartidas entre el autor de las obra y el conocedor de las técnicas.

Las dos últimas categorías no participan de ningún aspecto de colaboración creativa. Son enunciadas y están presentes en el cuadro, por su importancia dentro de la práctica de las artes gráficas y para hacer comprensible la actitud de artistas y grabadores presentes en esta tesis que desarrollaron parte de su obra, no ampliamente estudiada aquí pero si citada, en estos dos apartados.

\section{V) Grabador Reproductor.}

En esta categoría, partiendo de una imagen existente de un autor totalmente ajeno al proceso técnico (el artista que ha elaborado la idea en otro medio, escultura, pintura, fotografía, etc.), el técnico grabador es responsable en solitario de todos los demás pasos que implican la creación de la matriz y la estampa final resultante. Estamos en el caso del grabado reproductivo que a lo largo de la historia ha cumplido una importantísima función en la difusión de movimientos religiosos, políticos, artísticos y culturales y que desde la aparición de la fotografía ha perdido casi por completo su razón de ser. Su subsistencia en la actualidad responde generalmente a cuestiones mercantilistas.

\section{VI) Artista Grabador B.}

La obra desarrollada por un único individuo conocedor de los mecanismos técnicos y las posibilidades artísticas que el medio gráfico ofrece. En la Historia del Arte encontramos numerosos ejemplos de artistas en los que la obra gráfica se desarrolla de forma independiente a la de otras facetas creativas del mismo artista. Durero, Rembrandt, los Tiepolo o Picasso desarrollan obra gráfica en solitario, o en colaboración con otros técnicos en ocasiones, al margen de la faceta artística por la que fueron principalmente conocidos. Otros, como Benedetto Castiglione, ofrecen una mayor importancia en su trabajo como grabadores que en sus otras facetas artísticas y finalmente tenemos la obra de aquellos artistas, como Piranessi, que han desarrollado su creatividad mediante la gráfica.

En las intersecciones de los dos ejes que configuran el esquema gráfico de fases de creación y grados de colaboración, se encuentran según los casos, los dos elementos esenciales que están presentes en mis planteamientos sobre la creatividad compartida: el técnico grabador y el artista.

- El técnico grabador C: En este estudio se le define como experto en las técnicas propias del medio y en los aspectos esenciales de la creación artística. Conocedor de 
las capacidades y la imagen de los artistas con que se compromete a colaborar, creador el mismo y capaz de manejar la compleja infraestructura necesaria de que un taller de grabado contemporáneo está dotado. Todas estas características son de gran importancia en la práctica habitual de empresas colaborativas y aún más cuando el técnico grabador es además docente. El aspecto de los planteamientos temáticos y de la generación de ideas ha de ser estimulado por el en el aprendizaje del alumno, artista en formación.

-El artista A: Profesional que desarrolla su actividad creadora en cualquier rama de las artes y está interesado en producir su obra utilizando las técnicas propias del grabado. El desconocimiento parcial o completo de estas técnicas o la carencia de la infraestructura necesaria le conducen a entablar una relación de cooperación, con diversos grados de implicación, con un técnico o equipo de técnicos profesionales del grabado para la consecución de sus fines.

Artista A y técnico grabador $\mathbf{C}$, al confluir en una fase y categoría determinadas producen unos resultados enriquecidos por la colaboración. El análisis de todos los conjuntos de variables posibles a lo largo de los distintos casos y procesos nos va ha permitir demostrar lo esencial de esta tesis. La importancia del técnico grabador en el proceso técnico y en muchos casos también en el creativo de la obra gráfica. 


\section{II- Estudios Históricos.}

\section{II-1: Categorización de los artistas y grabadores históricos.}

Cada uno de los artistas, técnicos y escuelas analizadas en esta tesis doctoral, responden a unas características particulares que las significan en el campo de la colaboración creativa del grabado. En un espacio que iría desde la labor solitaria de un grabador o de un artista hábil en la gráfica, con el conocimiento de las técnicas necesarias para crear matrices permanentes y estamparlas según sus necesidades, hasta el trabajo en equipo de mecenas, editores, artistas, dibujantes, grabadores, y estampadores, hayamos diversas formas de colaboración en las que el grado de implicación de unos y otros varía sustancialmente. En muchas ocasiones un mismo equipo de artista y grabador acometen sus obras de diferente manera, pudiendo encajar en un apartado del cuadro en un trabajo y en otro en el siguiente. El grado de colaboración veremos que depende tanto del carácter de los individuos implicados como del periodo histórico al que pertenecen.

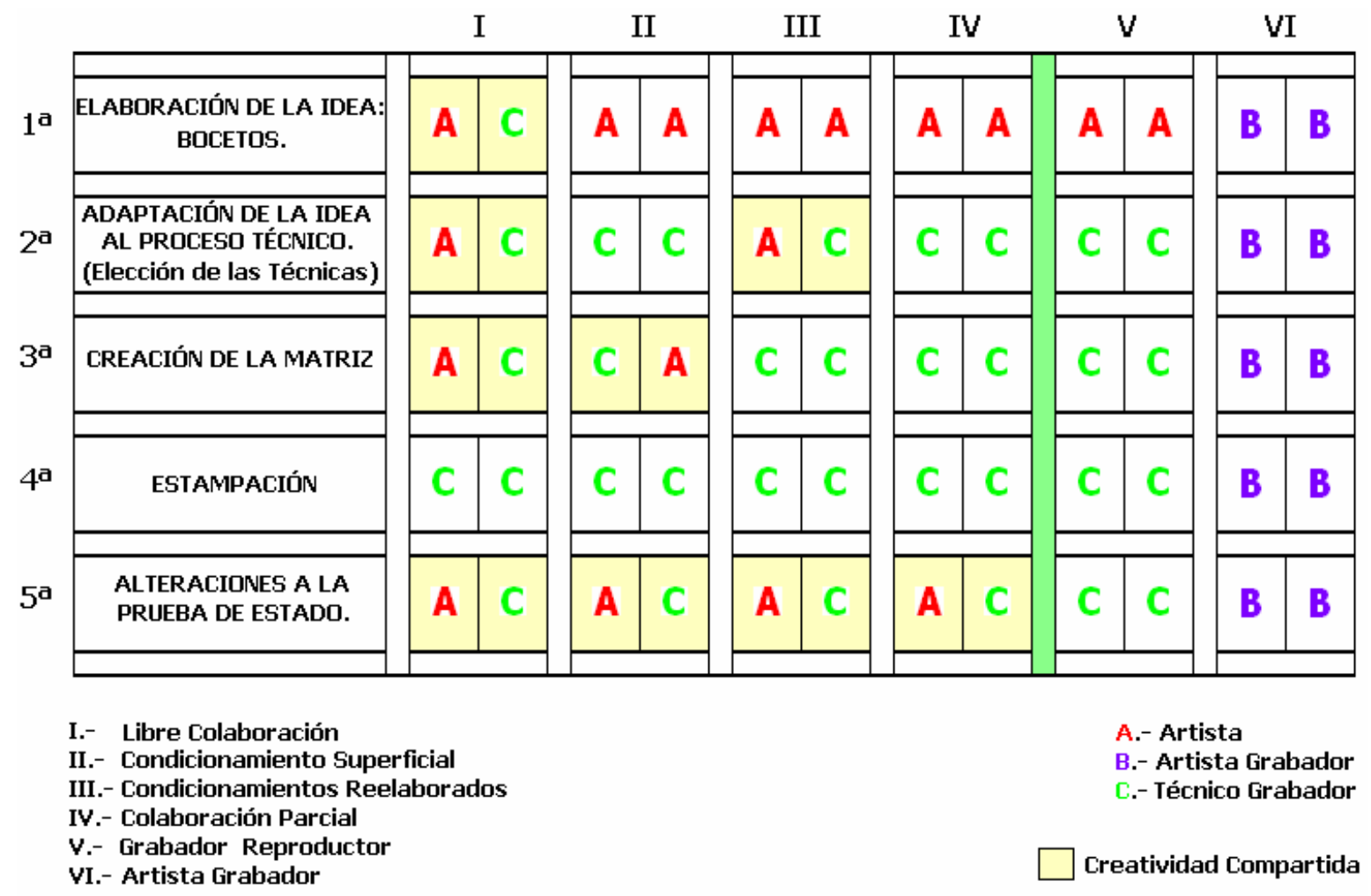

CATEGORÍAS Y GRADO DE COLABORACIÓN EN LAS ETAPAS DE CREACIÓN DE LA IMAGEN GRABADA

Marcantonio Raimondi, ha sido considerado generalmente como el artista reproductivo por antonomasia y en un número elevado de las obras que salieron de sus manos sin duda así fue. Las reproducciones exactas de xilografías de Durero en talla dulce o las interpretaciones de originales completos de grandes maestros cuando su carrera ya está consolidada, son obras de reproducción ejecutadas con maestría. En el caso de los Dureros de Raimondi vemos como un técnico grabador (C) reproduce 
la obra de un artista (A) que ideó el original, sin participar este último en absoluto en el resto de un proceso claramente enmarcado en la categoría $\mathbf{V}$ (grabador reproductor) del cuadro. En muchas de sus obras de pequeño formato basadas en dibujos ajenos, la situación es la misma, pero en otras la categorización será diferente. Para sus grandes proyectos de edición en compañía de artistas como Rafael o Bandinelli, la cercana colaboración entre ellos debió conducirles a tomar decisiones en grupo sobre el resultado final, es decir artistas (A) y técnico grabador (C) procedían a alterar la prueba de estado casi ultimada para dejarla lista a gusto de todos. Por lo tanto el proceso estaría inserto en la categoría IV (colaboración parcial).

El aspecto para mi más interesante de Raimondi, es el de la obra que le da el prestigio suficiente para establecerse en Roma como profesional y en la que procede como artista grabador (B), según mi opinión. Siguiendo un proceso que hoy calificaríamos como apropiacionismo, Raimondi mezcla progresivamente con más acierto: influencias de Durero, arquitecturas propias de la estampa nórdica, figuras influidas o copiadas de Giorgione, Miguel Ángel o Rafael y paisajes de Van Leyden, que unidos a su admiración por la estatuaria clásica y a su gusto por la arquitectura plenamente renacentista, darán lugar a una obra plenamente original que yo encuadraría en la categoría VI (artista grabador).

Fontainebleau. Esta escuela multinacional de grabadores nace para difundir el original manierismo de influencias mayoritariamente italianas que se produjo en la transformación arquitectónica y decorativa del palacio francés del mismo nombre.

Cuando los grabadores interpretan los originales y sus correspondientes bocetos de Rosso, Primaticcio o Penni (A), están trabajando claramente como técnicos grabadores (C) y su intención es reproducir en estampas las imágenes novedosas del palacio. La naturaleza misma de la obra, de carácter privado al servicio del rey, les impulsa a reproducir los logros allí conseguidos y así difundirlos. En origen, parece ser que las estampas creadas son ajenas a intereses comerciales y es improbable que los pintores de los originales controlaran los resultados. En estos momentos, los iniciales de la escuela, las obras formarían parte del grupo $\mathbf{V}$ (grabador reproductor). Esto es indudable en el caso de obras que reproducían originales de Rosso una vez desaparecido el artista.

Pero al avanzar en el tiempo y perfeccionarse los resultados, también encontramos obras creadas en colaboración entre artista y grabador. Cuando los pintores encargados de dirigir la escuela creada in situ, Primaticcio y después Penni, veían reproducida su obra, sin participar en la elección de las técnicas ni en la creación de la matriz y su estampación, sin duda tuvieron que opinar sobre las pruebas obtenidas. Nos encontramos entonces dentro de la categoría IV (colaboración parcial).

También encontramos otras obras creadas por artistas grabadores (B) como Antonio Fantucci, responsables en solitario de todos los pasos de creación en la mayor parte de sus estampas. Categoría VI (artista grabador).

En una escuela tan variada por su número de componentes y los orígenes de las estampas grabadas, cada personaje y obra exige un análisis específico de 
categorización y del grado de implicación de sus responsables que el estudio a ellos dedicado pretende esclarecer. Así encontraremos ejemplos de obras creadas en mayores grados de colaboración, como la III (condicionamientos reelaborados), entre los maestros impulsores de la escuela, Primaticcio y Penni y los grabadores de ella.

Antón van Dyck. En las ocasiones en que este autor actúa solo, casi siempre en estados intermedios de estampas de los que se realizaron un cierto número de copias (podríamos hablar de ediciones intermedias), tenemos que referirnos a su obra como propia de un artista grabador (B) responsable del proceso completo. Aunque físicamente no cabe duda de que no fuera el estampador, este no debió tomar ninguna decisión propia en el proceso de estampación dada la poca dificultad de este paso en el caso de aguafuertes sencillos y la experiencia de Van Dyck en el medio. En esta partida de su obra estamos en la categoría VI (artista grabador).

Para muchas de estas estampas, en las que ya ha trabajado en la creación parcial de la matriz, Van Dyck (A) colabora estrechamente en la continuación del proceso con sus grabadores de confianza (C). Partiendo de una idea propia, participa en la recreación del original realizando bocetos adaptados a las técnicas específicas del grabador elegido, aguafuerte, buril o ambas en muchos casos y planteando alteraciones sobre las pruebas de estado. $Y$ ahora encontramos una particularidad que afecta solo a dos obras del conjunto, los retratos de sus colaboradores Lucas Vorsterman y Paulus Pontius (C). Los dos posarán para él y sus retratos se convertirán en parte de este pequeño grupo de estampas extraordinarias. Posando para el original, están participando con su presencia y actitud en la elaboración de la idea. Como excepción, en estas dos obras hablamos de categoría I (libre colaboración).

Para el resto de sus obras en colaboración, aquellas creadas en vida del artista y en las que su implicación consiste en perfeccionar bocetos y elegir resultados finales, nos encontramos en la categoría III (condicionamientos reelaborados) y en el enorme corpus de obra gráfica realizada tras su muerte, en la $\mathbf{V}$ (grabador reproductor).

Los Tiepolo. Si tomamos como ejemplo la figura de Giambattista Tiepolo, vemos que al realizar su obra más íntima, Scherzi y Capricci, ajena al propósito de difundir en estampas la imagen de una obra creada para otro medio, actúa como un artista grabador(B), dentro de la categoría VI (artista grabador). Cuando su hijo Giandomenico graba sus series basadas en obra propia también actúa como tal (B) y en la misma categoría. Más cuando acomete la serie de cabezas según originales del padre, actúa como un grabador de interpretación, solo como técnico (C) al servicio de una imagen únicamente debida al espíritu creador de Giambattista (A), entrando este proceso en la categoría $\mathbf{V}$ (grabador reproductor).

Si Lorenzo o Giandomenico Tiepolo realizan un grabado basado en las obras al fresco en la que participaron directamente de la autoría, vista la forma de colaborar entre padre e hijos en este tipo de encargos, los resultados pertenecerían a la categoría I (libre colaboración).

Cierto es que en el caso de esta saga familiar nos movemos en el terreno difícil de acotar la autoría de cada uno de los tres componentes del grupo. En la obra realizada 
al fresco, Wurzburgo, Madrid, etc. , sabemos de la implicación directa de los hijos en el acto creativo, aunque no en que medida lo estuvieron. En la obra gráfica basada en lienzos de Giambattista (A), cuesta hablar de grabado reproductivo dado el grado de identificación entre artista y grabadores (C), la III (condicionamientos reelaborados) sería la categoría en la se mueven en este caso. Con una matización, la aportación estilística de cada uno de los hermanos es indudable. Las diferencias, dentro de un espíritu común resultan evidentes.

John Constable y David Lucas, son capaces de expresar en su trabajo común de creación gráfica, de modo inmejorable, las características propias de la pintura de Constable mediante una traducción en claves de claroscuro propias de la compleja técnica de grabado en que Lucas estaba especializado, la mezzotinta o manera negra.

Partiendo de obras de gran formato en algunos casos y de bocetos al óleo especialmente creados para la ocasión, Constable (A) elige la técnica que considera idónea y surte a Lucas (C) de los medios necesarios para llevar a cabo su labor de traducción. Las correcciones de pruebas de estado han llegado hasta nuestros días para documentar ampliamente el complejo proceso que llevó a unos resultados inmejorables. Categoría III (condicionamientos reelaborados).

Tras la desaparición de Constable, David Lucas volverá a grabar siguiendo sus originales en funciones claras de grabador reproductor dentro de la categoría $\mathbf{V}$ (grabador reproductor). En estas obras se ha suavizado u omitido el dramatismo propio del periodo en el que Constable supervisaba la creación de las mezzotintas. Como el éxito comercial no acompañó a la iniciativa editorial conjunta, al igual que le había ocurrido a Constable en el terreno pictórico, puede que Lucas suavizara las características que no agradaron al mercado británico. Ya fuera por este motivo o porque la ausencia del control de Constable, autor de las obras originales según las cuales siguió grabando Lucas, la realidad es que entre las obras pertenecientes a fechas anteriores a la muerte de Constable y las de fecha posterior a esta, las diferencias son muy grandes.

Estados Unidos (1960-1990). Este es el periodo histórico y el lugar en el que la reivindicación del grabado colaborativo y de la importancia de ejercer la creación de forma compartida se consolida definitivamente. En Estados Unidos, artistas, grabadores e instituciones fueron capaces de darle el giro necesario a la creación de obra gráfica para ponerla al mismo nivel que las demás disciplinas artísticas habían alcanzado tras la aparición de la fotografía y la revolución que las primeras vanguardias artísticas habían consagrado.

La colaboración en todos los aspectos creativos del proceso de la obra gráfica, envuelve a artistas de los dos movimientos principales del periodo, el expresionismo abstracto y el pop-art y a los técnicos que trabajaron en las fundaciones de más prestigio, como la ULAE, Tamarind, Tyler Graphics, etc. y en los innumerables talleres de menor envergadura de los Estados Unidos y Canadá. Refrendados los resultados por críticos, galerías, museos y universidades, se consolidó un mercado informado y respetuoso con esta forma de trabajar y de crear que nunca había estado reconocida del mismo modo ni desarrollada hasta sus límites. Los resultados en investigación 
sobre materiales, soportes, formatos o mezclas de distintas técnicas en una misma obra, consagran a este momento concreto, 1960-1990, como uno de los más fructíferos en la historia de la obra gráfica.

Por el grado de implicación entre los artistas (A) y los técnicos grabadores (C), las obras analizadas pertenecen fundamentalmente a las categorías I (libre colaboración), II (condicionamiento superficial) y III (condicionamientos reelaborados).

Comprobamos con estos análisis de los grados de colaboración entre los artistas y los correspondientes técnicos grabadores, que el nivel de integración entre ambos y la creatividad compartida desarrollada como consecuencia, se va incrementando con el transcurso de los tiempos. A mayor antigüedad cronológica parece corresponderle un menor grado de colaboración creativa y viceversa. La perdida del sentido testimonial y de difusión de imágenes e ideas que el grabado de reproducción tuvo desde sus orígenes hasta finales del siglo XIX, explicaría esta distribución temporal. El auge del grabado en el último tercio del siglo XX como medio autónomo de expresión artística, también lo hace. 


\section{II-2: Eclecticismo y codificación}

La obra del grabador italiano Marcantonio Raimondi pertenece a una tradición ya existente tanto en sus trabajos propios como en aquellos que en colaboración con artistas como Rafael o Julio Romano pretendían difundir sus logros artísticos con fines comerciales.

Ya a finales del siglo XV, artistas como Andrea Mantegna reproducen sus pinturas en grabados que pretenden difundirlas entre sus clientes potenciales y grabadores como el florentino Cristofano Robetta, graban composiciones inspiradas por Pollaiuolo o Filippino Lippi. La influencia del grabado del Norte de Europa, que en Raimondi es característica, ya se ha hecho sentir cuando el se inicia en la actividad profesional en autores que le precedían en el tiempo.

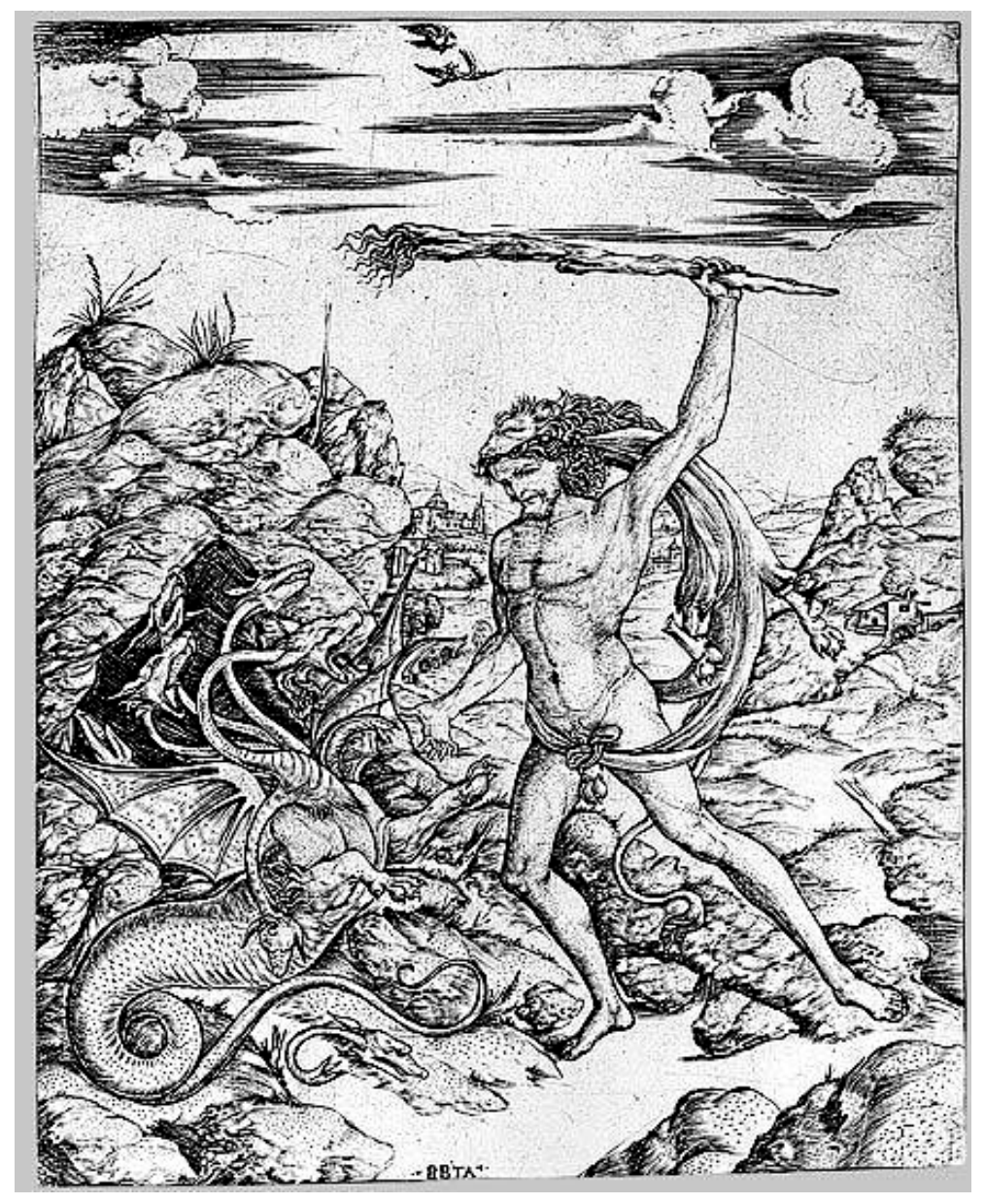

- Cristofano Robetta según Pollaiuolo, Hércules y la Hidra de Lerna. Buril. ca.1500.

Lo que conseguirá Raimondi, en su evolución como artista grabador, es desterrar una forma de grabar que imitaba el trazo de los útiles de dibujo sobre el papel al usar el buril sobre la plancha. Con el desarrollo de su método codificado de líneas paralelas, entrecruzadas y puntos que gradúan los pasajes tonales, profundiza en una concepción claroscurista de la imagen grabada, acercándola a los originales que interpreta en su monumentalidad y pictoricismo. 


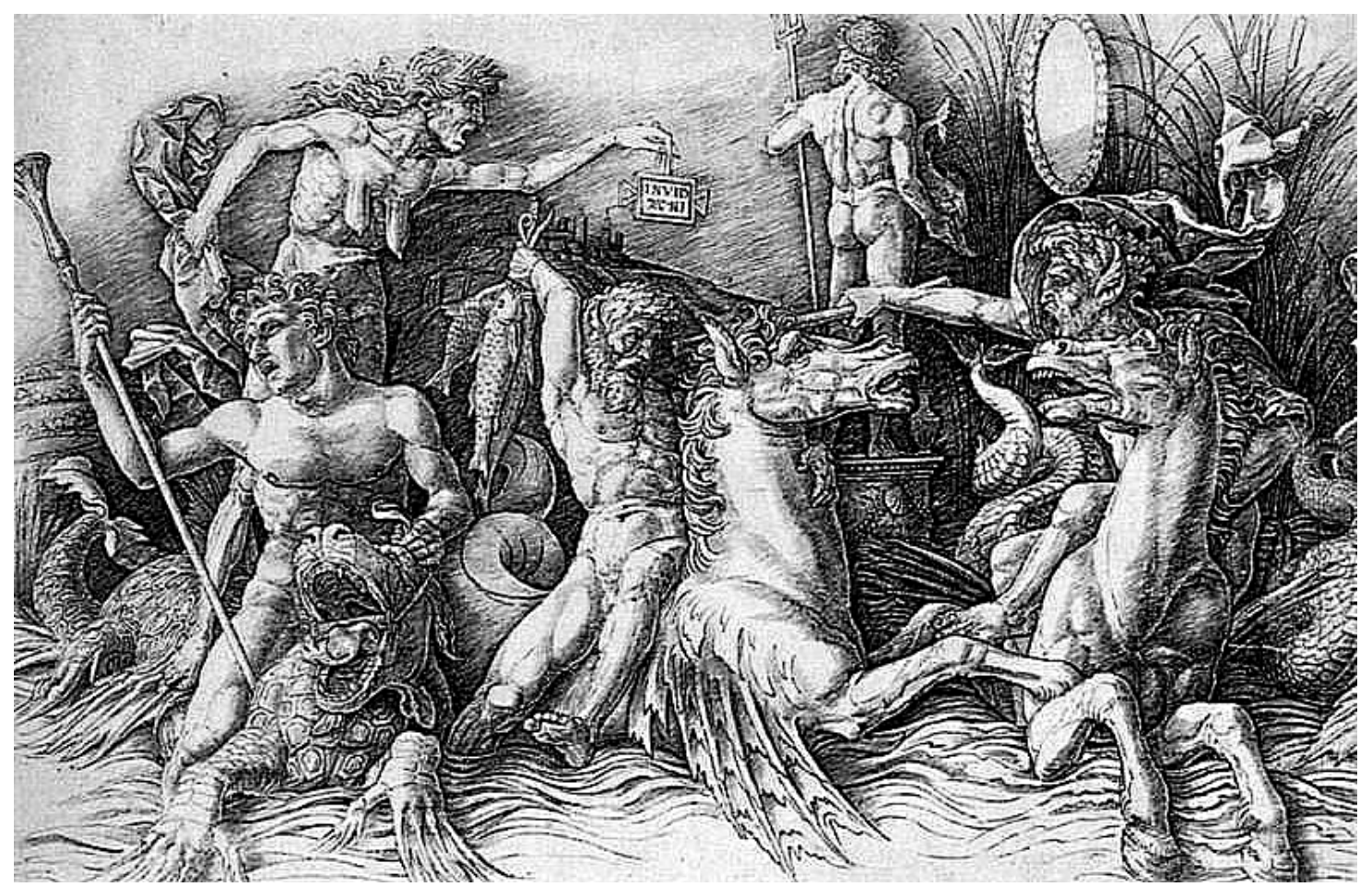

- Andrea Mantegna. La batalla de los dioses del mar, detalle. Buril, ca.1480.

Es difícil determinar el grado de colaboración entre Raimondi y los diferentes autores cuyos originales interpretó, sin duda no sería el mismo en todos los casos pero tenemos datos que nos hablan de la relación personal que mantuvo con algunos de ellos. La cercanía con Rafael y su círculo está documentada y Bandinelli declararía a su favor en el proceso tras la detención del grabador por la publicación de unas estampas que al papado le resultaron ofensivas. La misma novedad del sistema de representación desarrollado y su característica forma de trabajar, en la que rara vez reproducía una obra totalmente, mezclando fondos y figuras de distinta procedencia con elementos de su imaginación, debió conducir a los artistas a interesarse y opinar sobre planteamientos y resultados, es decir, a compartir el acto creativo.

La escuela de grabadores creada en Roma en torno a Raimondi, los seguidores y su vertiente empresarial, son vitales para el arte europeo. La imagen del Renacimiento italiano y la iconografía clásica y la religiosa se difunden desde este centro. Las características propias de este movimiento más el conocimiento y la adaptación de la forma de trabajar de grabadores del Norte como Schongauer, Durero o Van Leyden, originará un enorme volumen de imágenes reclamadas desde todos los centros europeos de producción artística. 
- Marcantonio Raimondi. (ca.1480-ca.1534)

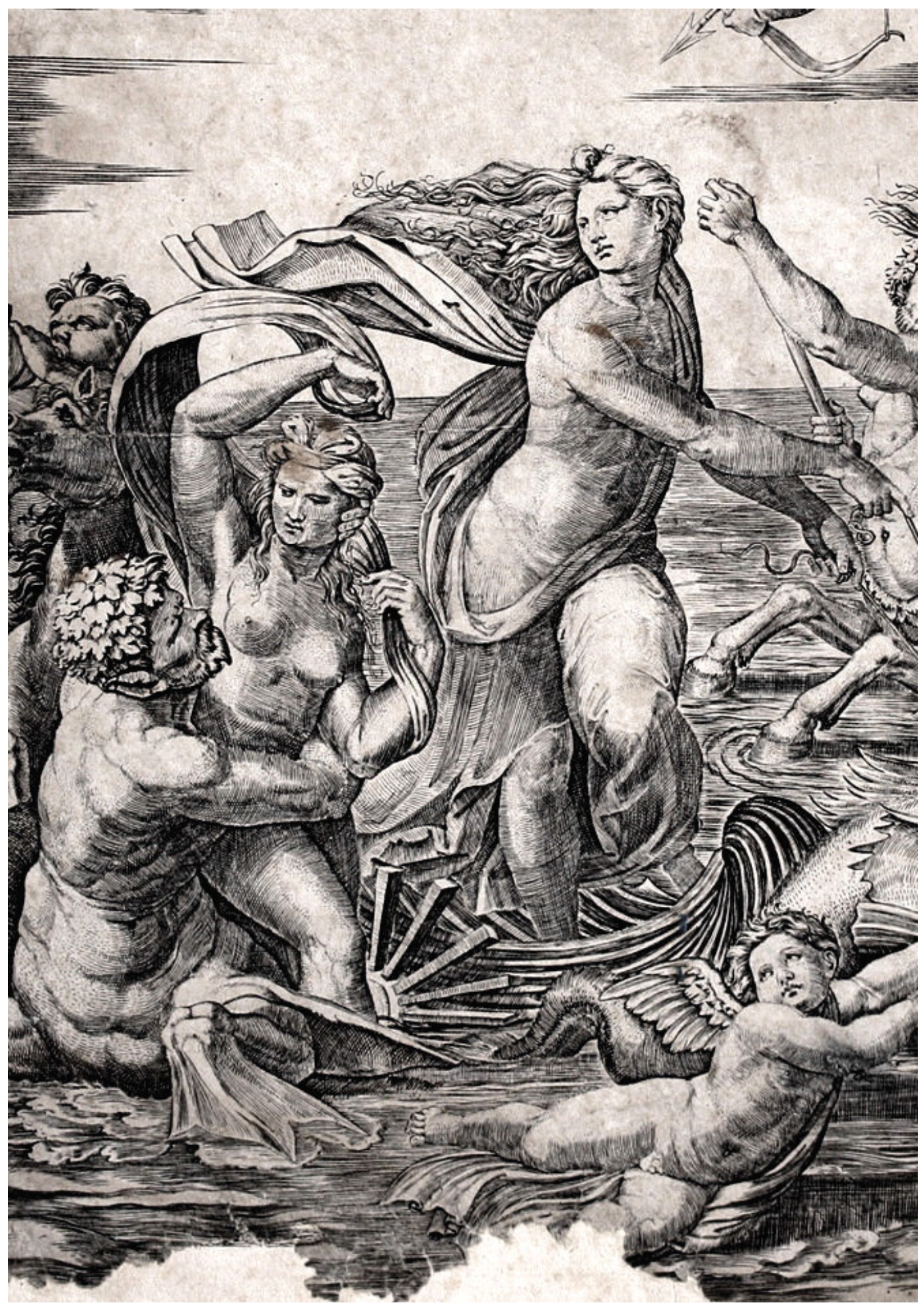

- Marcantonio Raimondi según Rafael. Galatea, detalle. Buril. 1515-16 
Marcantonio Raimondi, nace cerca de Bolonia alrededor de 1480 y se forma en el taller del pintor y nielista Francesco Francia. No conocemos pinturas originales de su mano, aunque si dibujos y es en el campo del grabado al buril en el que desarrollará su carrera con una triple vertiente que hace de su figura un hito fundamental en el desarrollo de la historia del grabado occidental. Su interés por la antigüedad clásica y por los grandes maestros del Renacimiento se verá reflejado permanentemente en su obra, siendo esta un instrumento vital para la difusión del humanismo en su vertiente artística por toda Europa. La creación de una sistematización en la técnica del grabado a él debida, será capaz de reflejar fielmente tanto los volúmenes de relieves y esculturas grecorromanas como la forma de pintar de artistas que desde Venecia, Florencia o Roma, estaban transformando la forma de entender la pintura. Por último, es la vertiente empresarial, con la creación de una escuela de grabadores y un taller especializado en producir sus imágenes, una iniciativa de gran trascendencia en la historia del arte. Un logro que posteriormente se repetiría en todos los focos artísticos importantes del continente europeo.

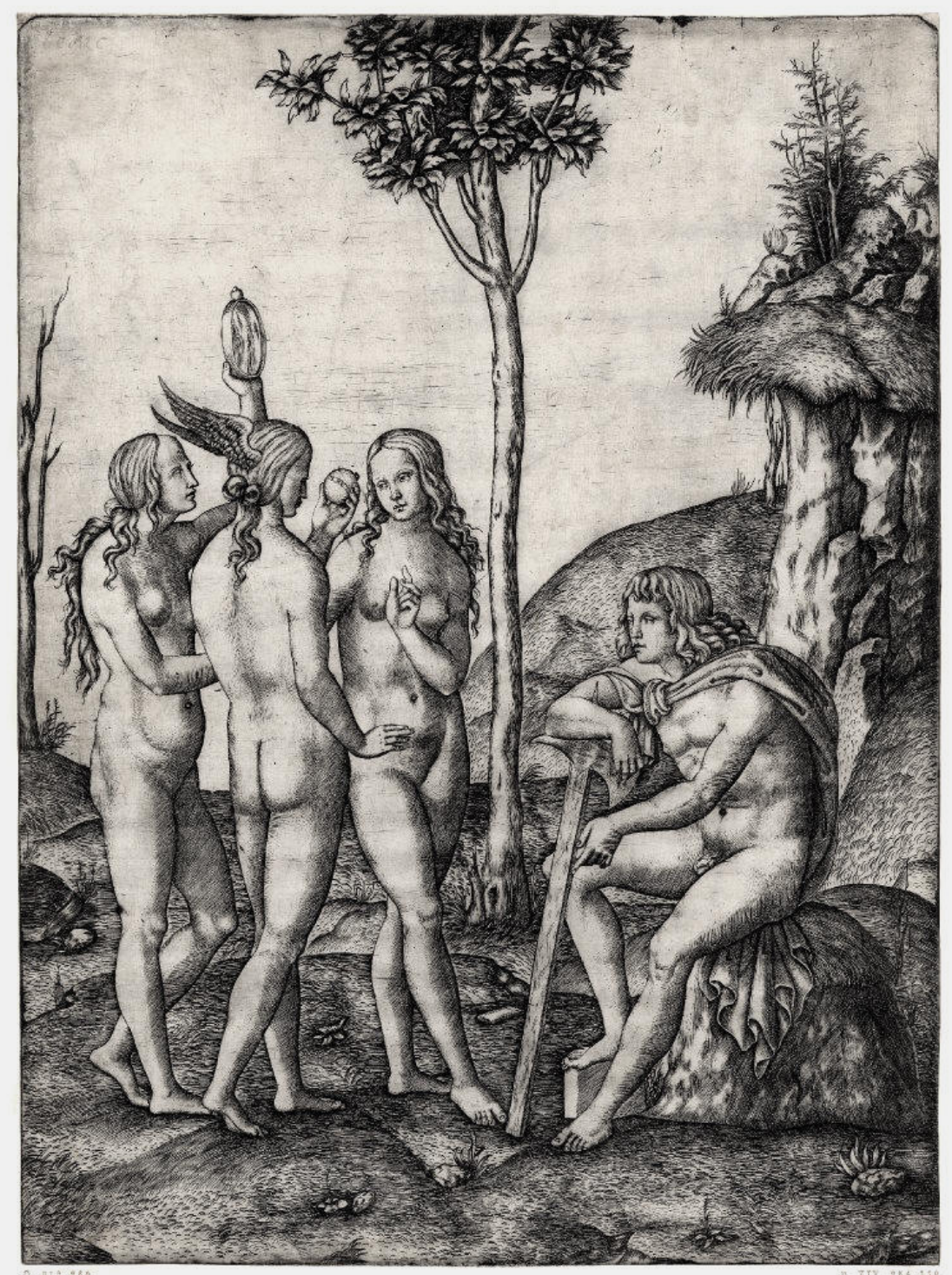

- Marcantonio Raimondi. El Juicio de Paris. Uno de sus grabados tempranos, realizado en Bolonia. 1502-04. 
Desde sus inicios en Bolonia y a lo largo de toda su carrera, asistimos a un progresivo desarrollo técnico siempre orientado a perfeccionar la forma de representar aquello que le interesa. No estamos delante exactamente de un grabador de reproducción, mejor podríamos considerarle un intérprete de las obras de los demás.

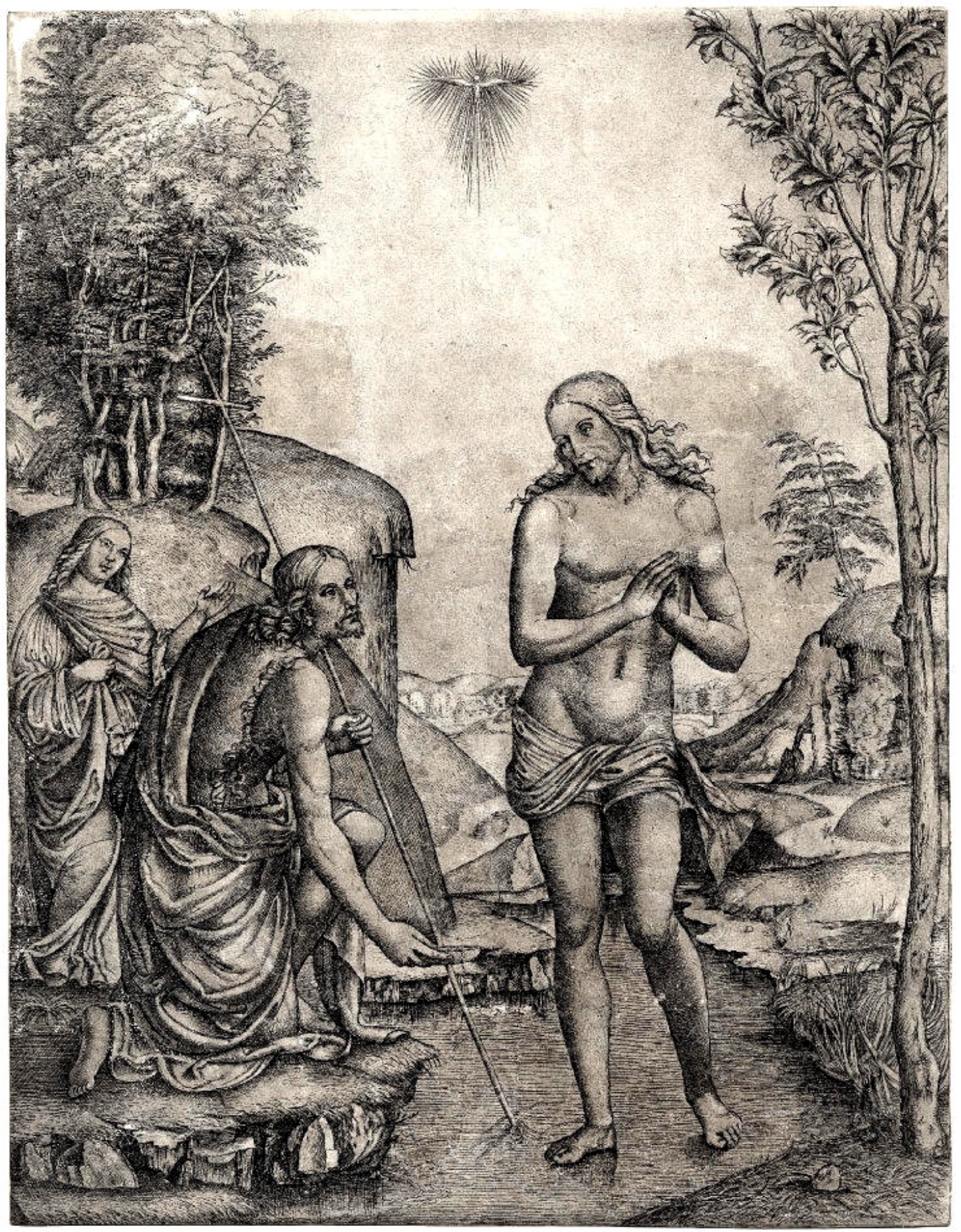

-Marcantonio Raimondi según Francesco Francia. El Bautismo de Cristo. Buril. 1502-04. 
Nunca reprodujo una obra completa de otro autor, salvo en el caso de Durero, si no que combinaba elementos de distintos orígenes para crean una nueva. Eligiendo, por ejemplo figuras de origen escultórico encuadradas en un paisaje más propio del grabado holandés que del italiano y composiciones u objetos derivadas de la obra de Durero, a esto también solía añadir elementos de su propia cosecha. Poseyó un sexto sentido para escoger elementos de diversos autores y trasladarlos con éxito y equilibrio a sus propias creaciones.

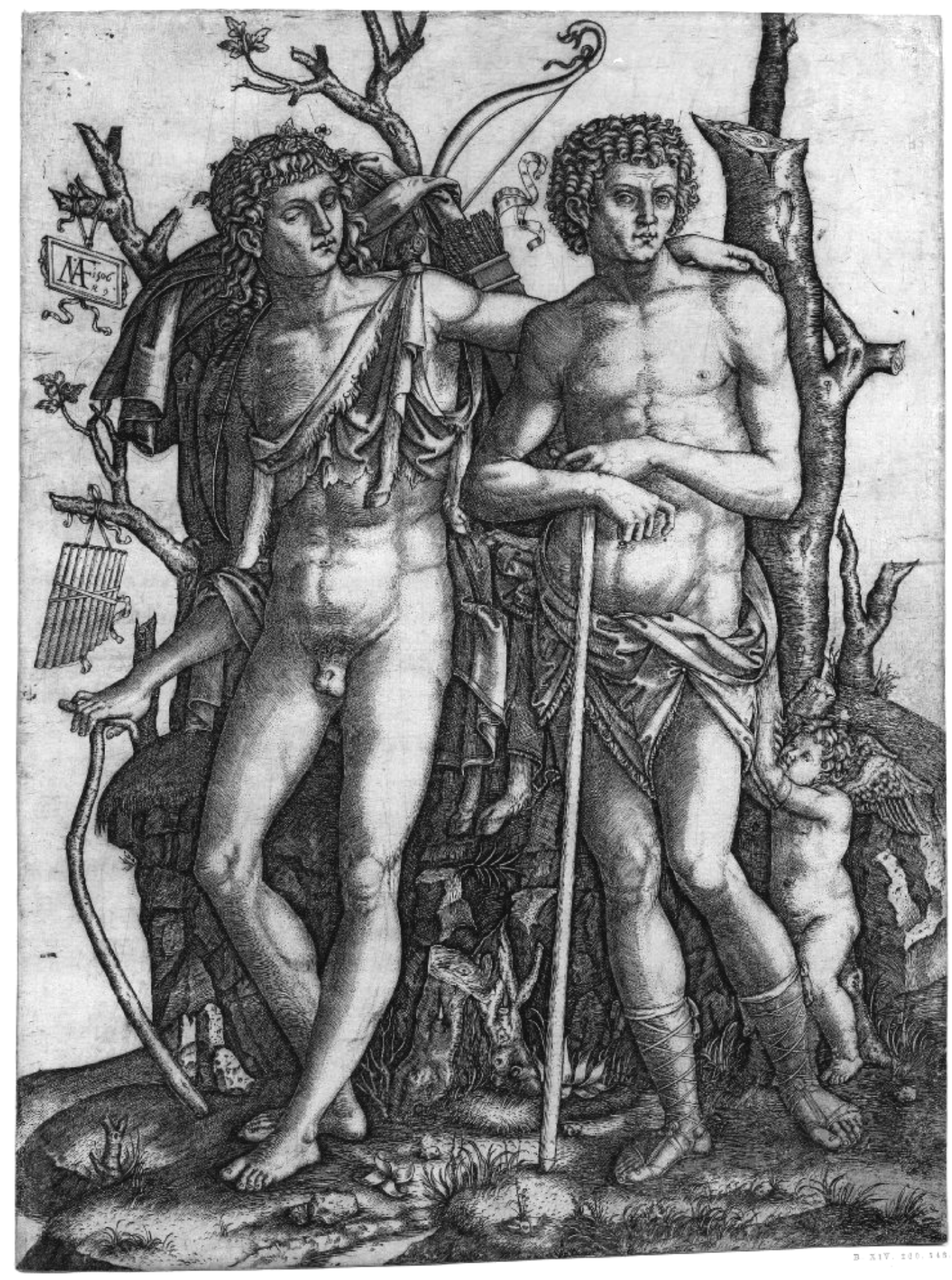

- Marcantonio Raimondi. Apolo, Jacinto y Cupido. Buril. 9 de Abril de 1506. 


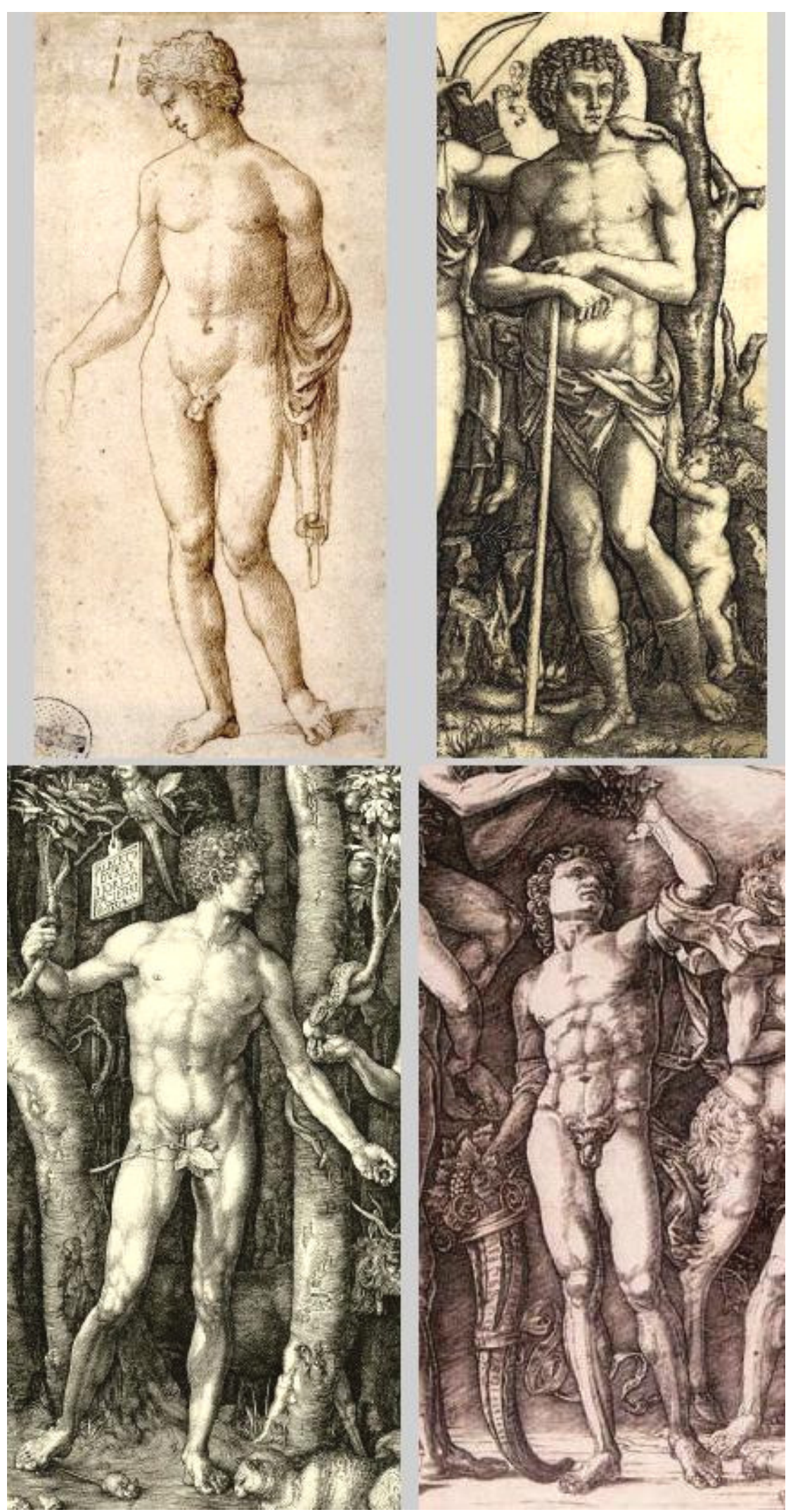

- Marcantonio Raimondi. Dibujo, 1506 y Jacinto, fragmento. Buril.1506.

- Durero, Adán.1504 y Mantegna, Bacanal con tonel.1470. Fragmentos. 


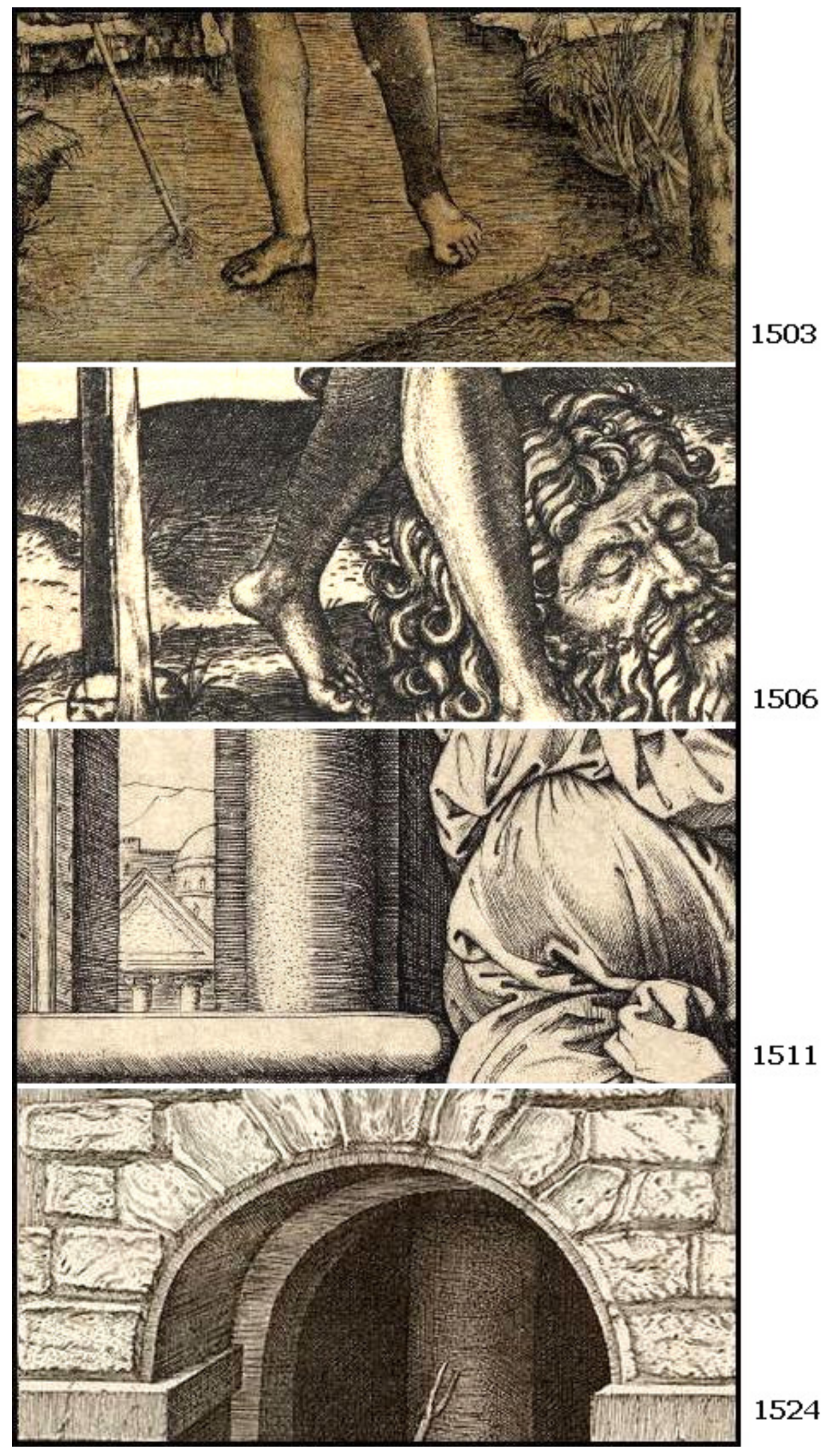

A lo largo de su vida desarrollará una técnica con la que se alejará de la imitación en grabado del trazo de lápiz o punta de plata propio de los dibujantes. 
Tramas entrecruzadas en los sombreados, grupos de líneas paralelas más o menos separadas, rectas o curvadas según marque la superficie o el volumen escultórico o pictórico representado, pequeños trazos claros y puntos para crear las transiciones tonales hasta el blanco puro, son los sencillos factores de su gramática gráfica con la que conseguirá una codificación eficiente para la representación de las obras y valores pictóricos del Renacimiento.

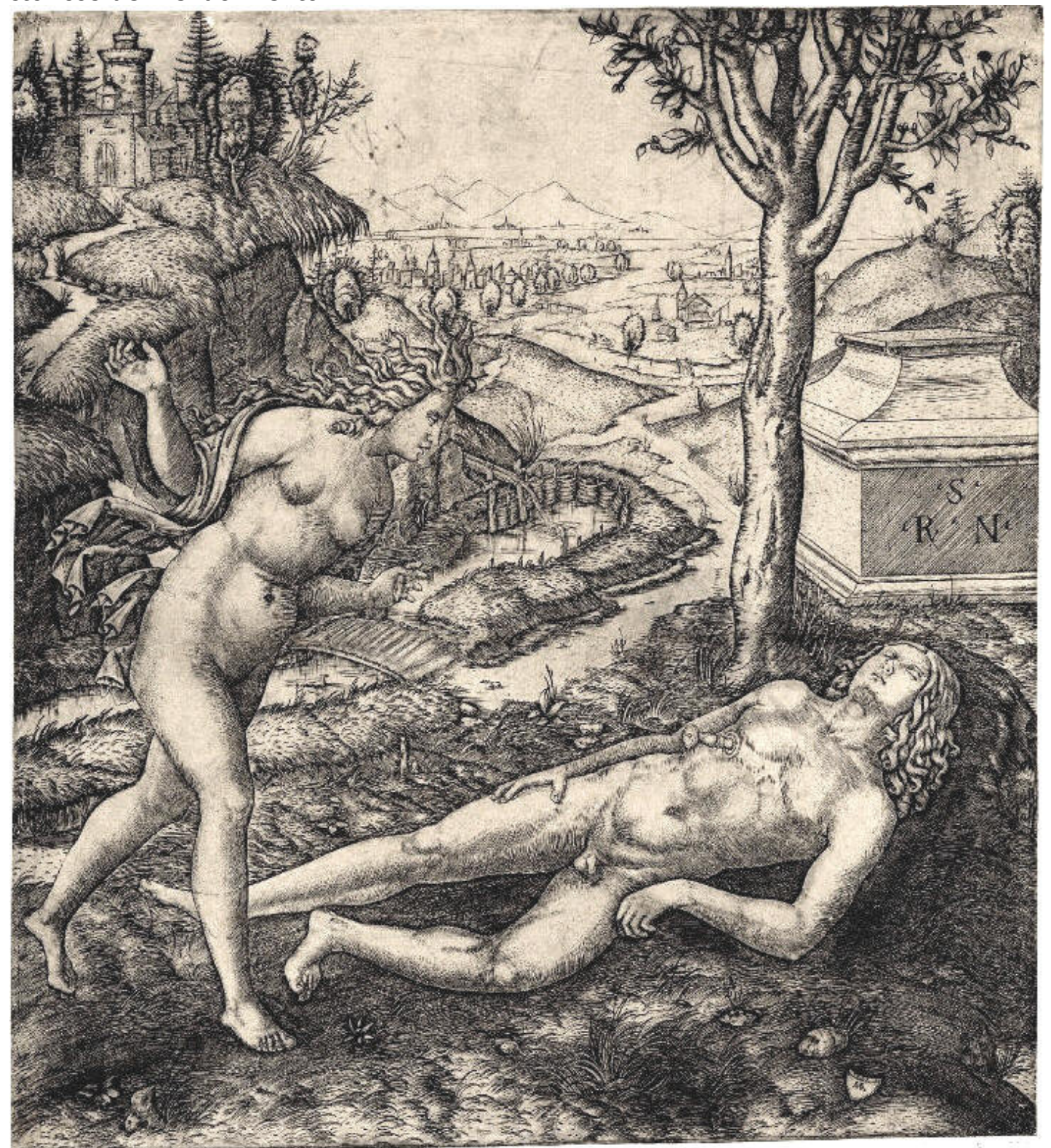

- Marcantonio Raimondi, Píramo y Thisbe. Buril. 1505.

Píramo y Thisbe es la primera obra datada con seguridad en 1505 y en ella están todas las características que Marcantonio desarrollará a lo largo de su vida. Influenciado por Francesco Francia, incorpora elementos dependientes de la obra de Durero en el medio y último plano de la composición. Su gusto por la antigüedad clásica esta en el origen del tema que proviene de las Metamorfosis de Ovidio y el tratamiento de las figuras incide en su aspecto volumétrico, destacándolas del fondo y potenciando su monumentalidad. 
Vasari sitúa a Raimondi en Venecia en 1506. En esta ciudad trabajará simultáneamente en varios estilos. Además de producir obras influenciadas por autores locales como Giorgione, inicia la tarea de reproducir integramente grabados y xilografías de Durero, interpretando al buril esta última técnica. Llega hasta el punto de incluir en las copias el monograma $A D$ con que el alemán firma sus composiciones lo que le acarreará una denuncia ante las autoridades y un pleito pionero en la consideración del derecho de autor. La solución legal consistió solo en impedir que en las reproducciones posteriores apareciera el monograma de Durero.

La maniobra comercial que hoy calificaríamos como plagio, no se queda en eso. El estilo Durero, de poderosas líneas xilografícas, exactos modelados de la figura humana y precisos paisajes de fondo, quedará definitivamente incorporado al de Raimondi.

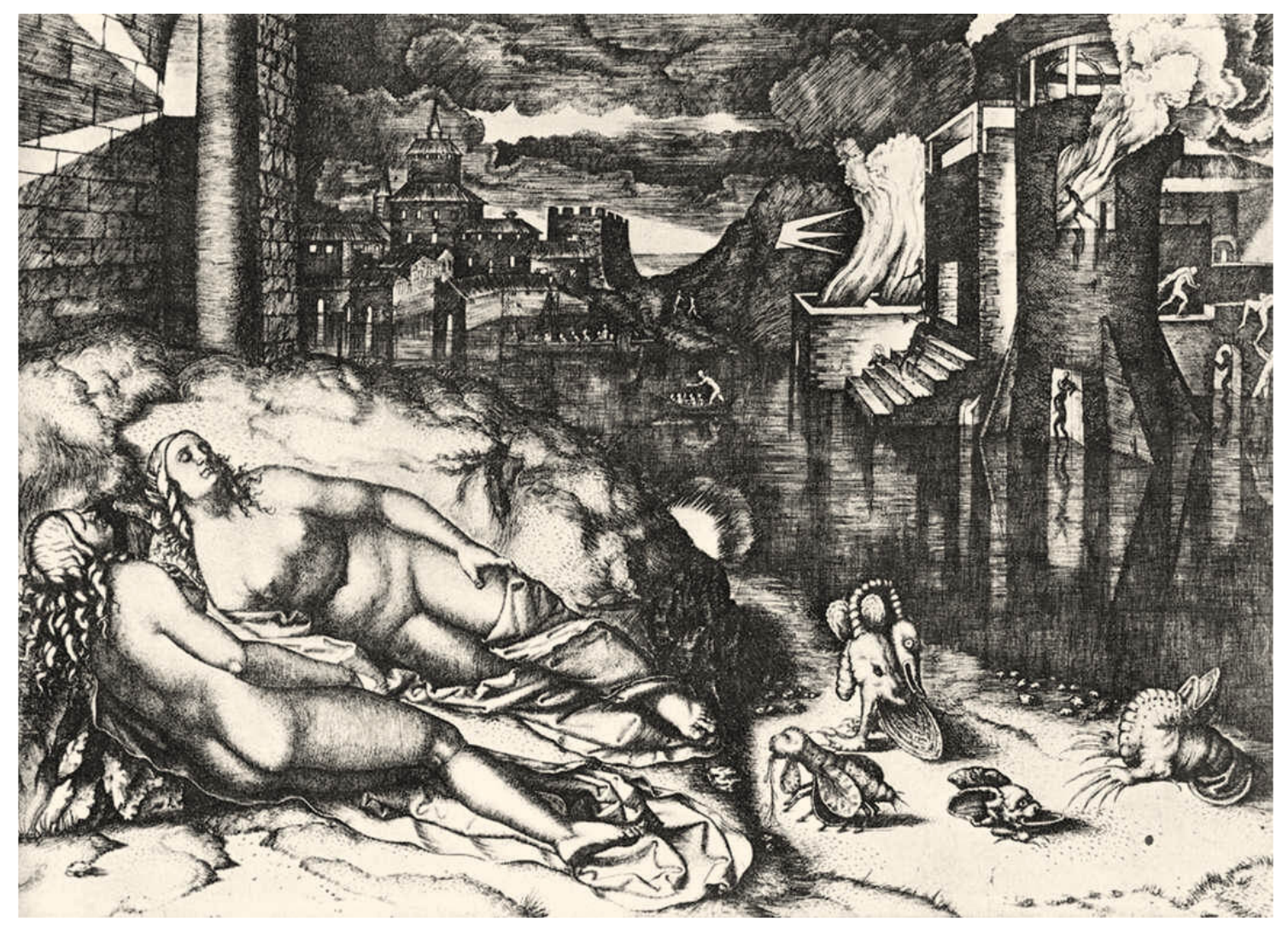

- Marcantonio Raimondi según Giorgione. El Sueño de Rafael. Buril. 1507-08

Esta obra parece reproducir un cuadro perdido de Giorgione que pudo representar el sueño de Hécuba ante la ciudad de Troya en llamas, tema enigmático de difícil interpretación, coincide en los tipos femeninos, el incendio y la tormentosa atmósfera con otras obras del artista veneciano. Técnicamente, Marcantonio se acerca por primera vez a un pictoricismo en su forma de grabar resuelto con éxito. El gran contraste de luz y sombra en el incendio y su reflejo en el río carece de las transiciones tonales que casi siempre utilizó y que ya aparecen en el modelado de las figuras y de todo el primer plano. Los animales fantásticos, propios de la pintura alemana y flamenca, podemos suponer que formarían parte del original de Giorgione. En caso contrario volveríamos a encontrar elementos de artistas y tradiciones distintos ensamblados por Raimondi en una nueva obra. 


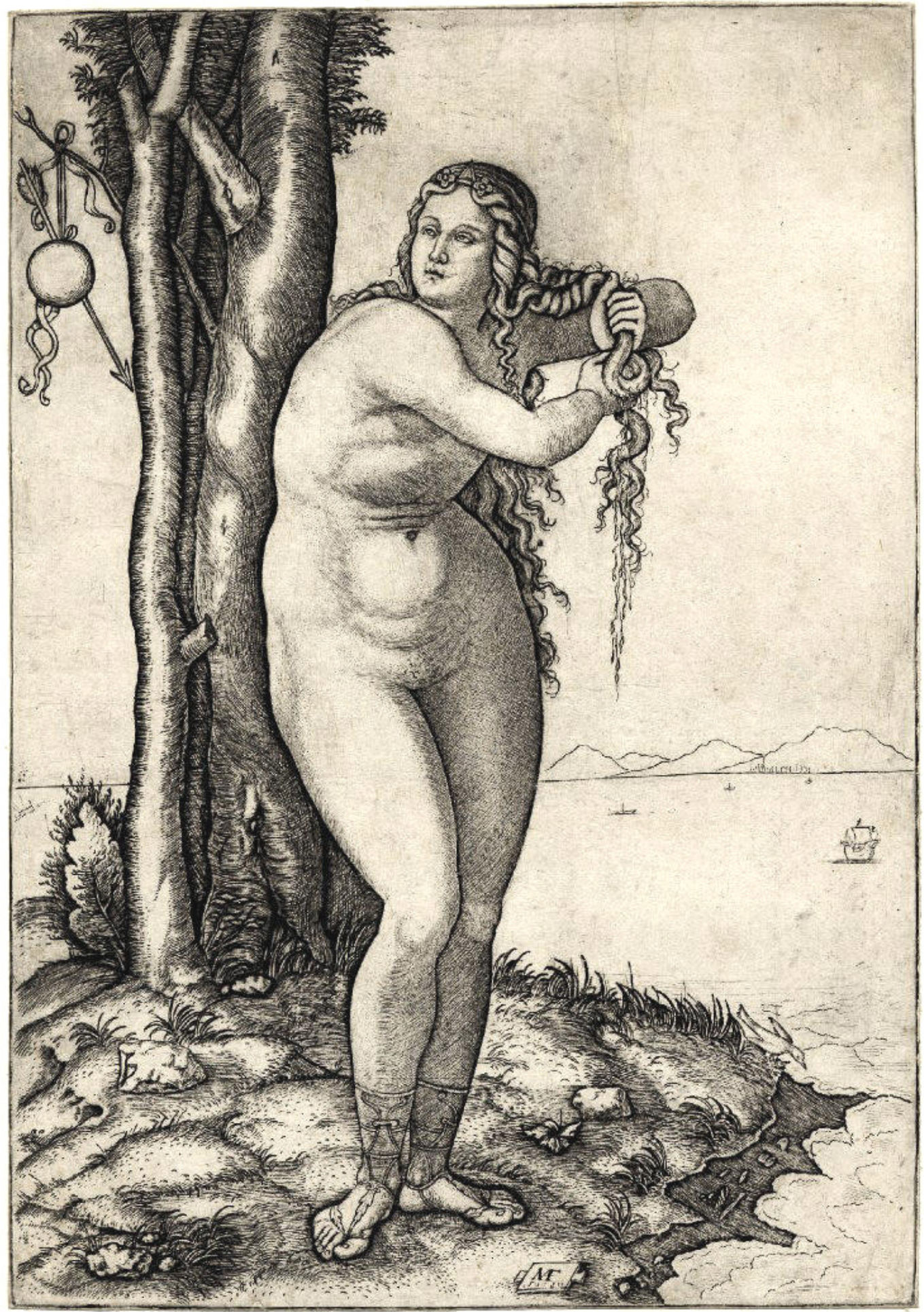

- Marcantonio Raimondi, Venus secándose el cabello. Buril. 1507.

La figura femenina pertenece a la tipología de Giorgione, el tratamiento del primer plano y el árbol derivan de Durero, mientras que el horizonte montañoso, el mar y los barcos adolecen de un desarrollo más eficaz. 


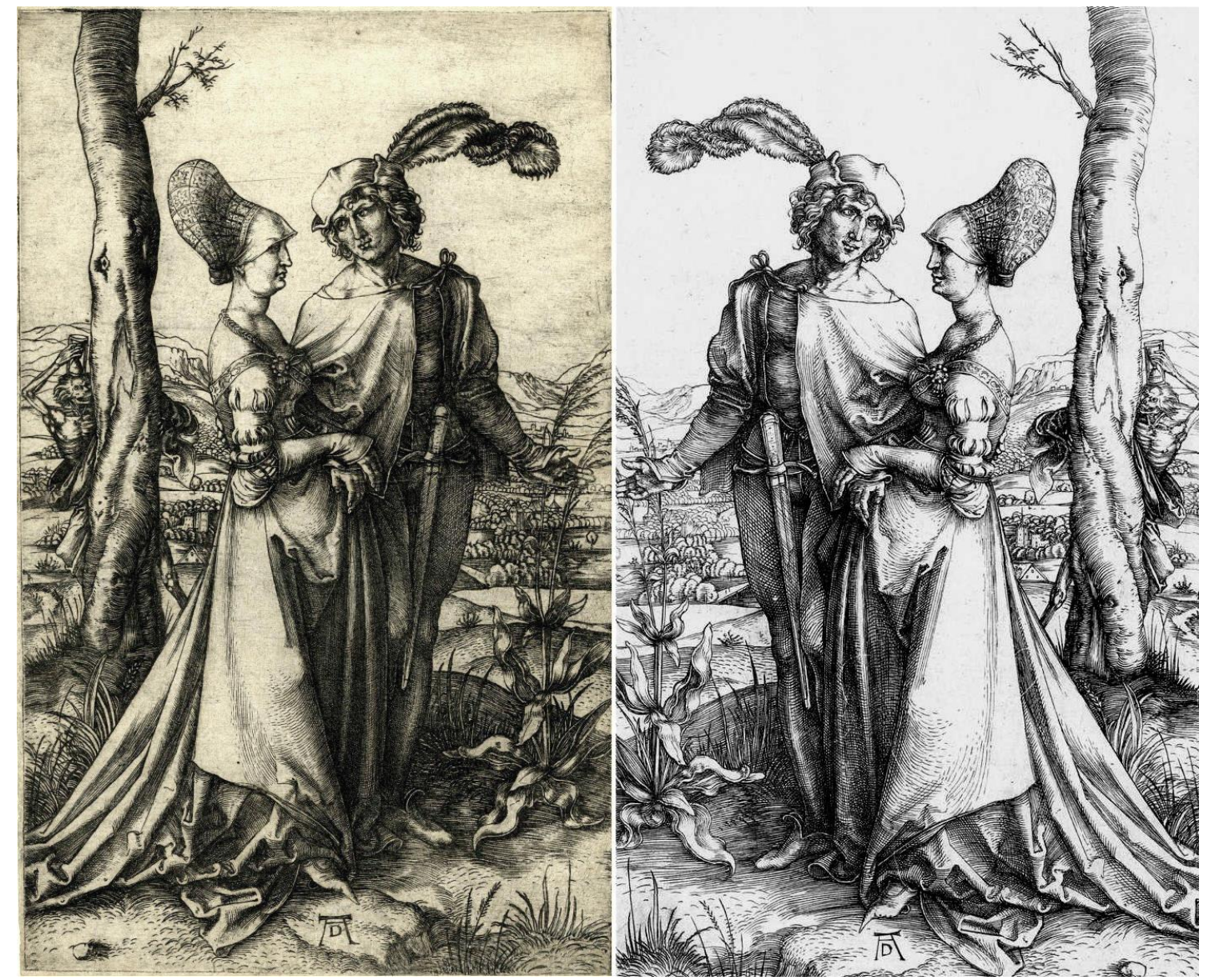

- Raimondi y Durero. Pareja paseando acechados por la muerte. 1508-1478

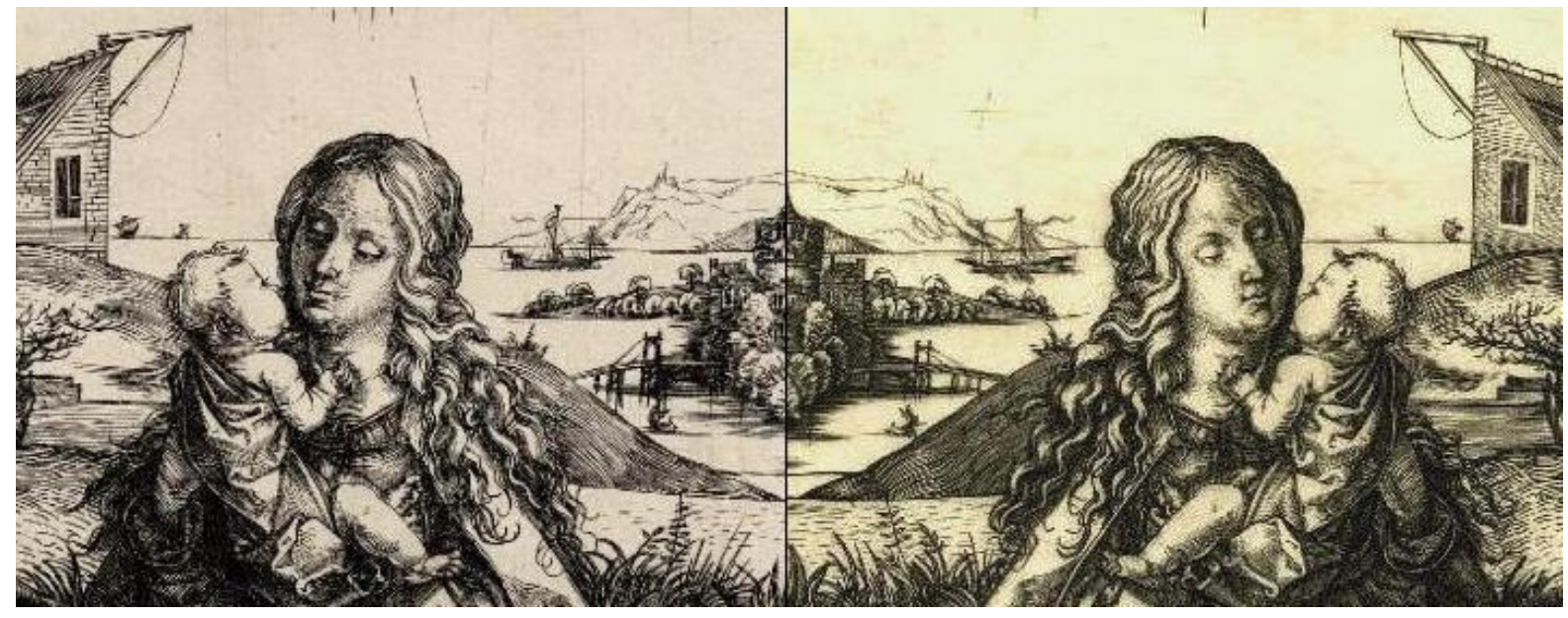

- La Virgen de la Libélula, fragmentos. Durero y Raimondi. 1495-1507

En ocasiones, las copias que Marcantonio realizó de las obras de Durero son tan exactas que se baraja la posibilidad de que fueran grabadas encolando sobre la matriz una estampa original y grabando con el buril las líneas a través del papel. 


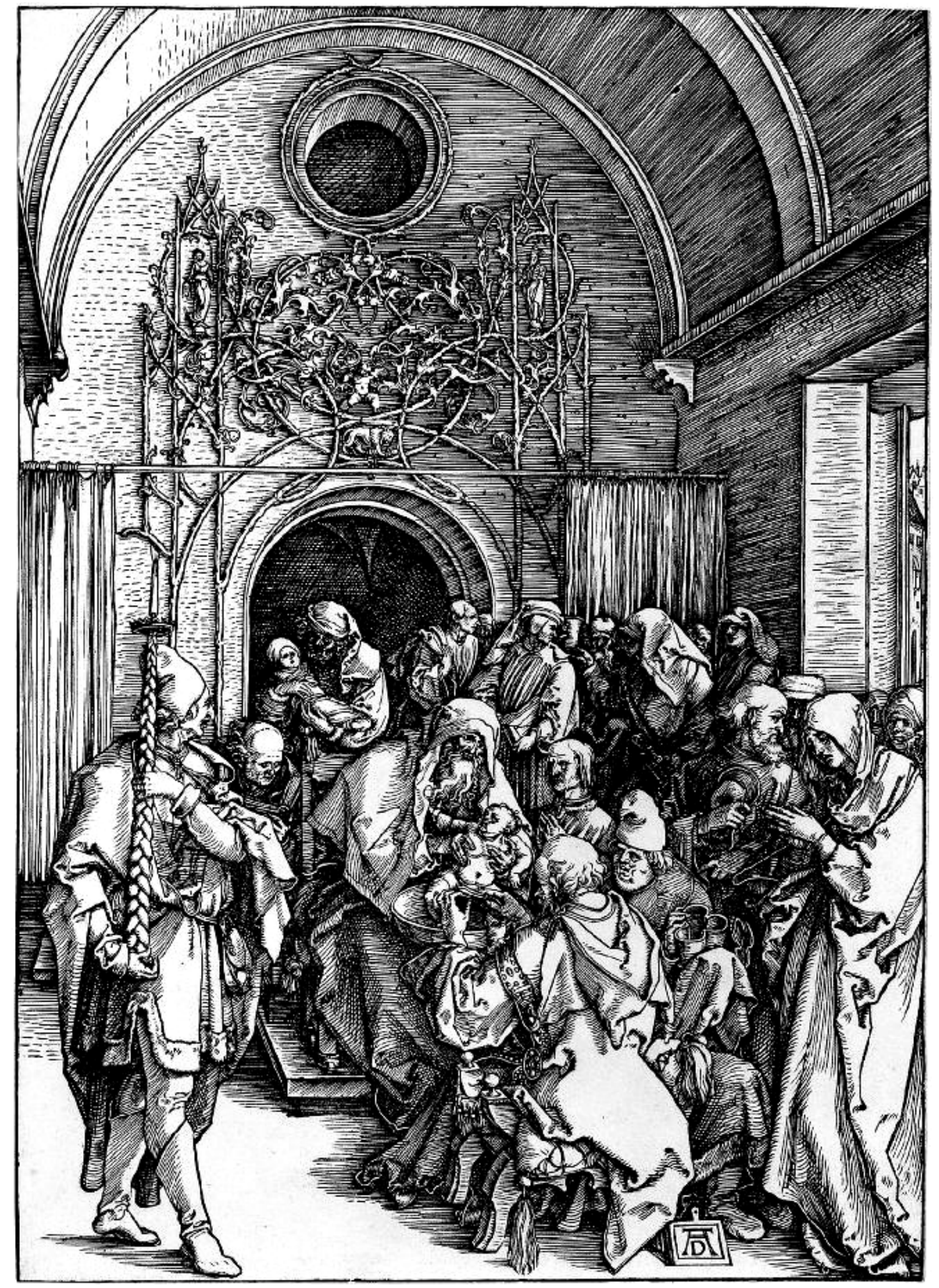

- Durero. La Circuncisión, de la serie Vida de la Virgen. Xilografía. 1503-05 


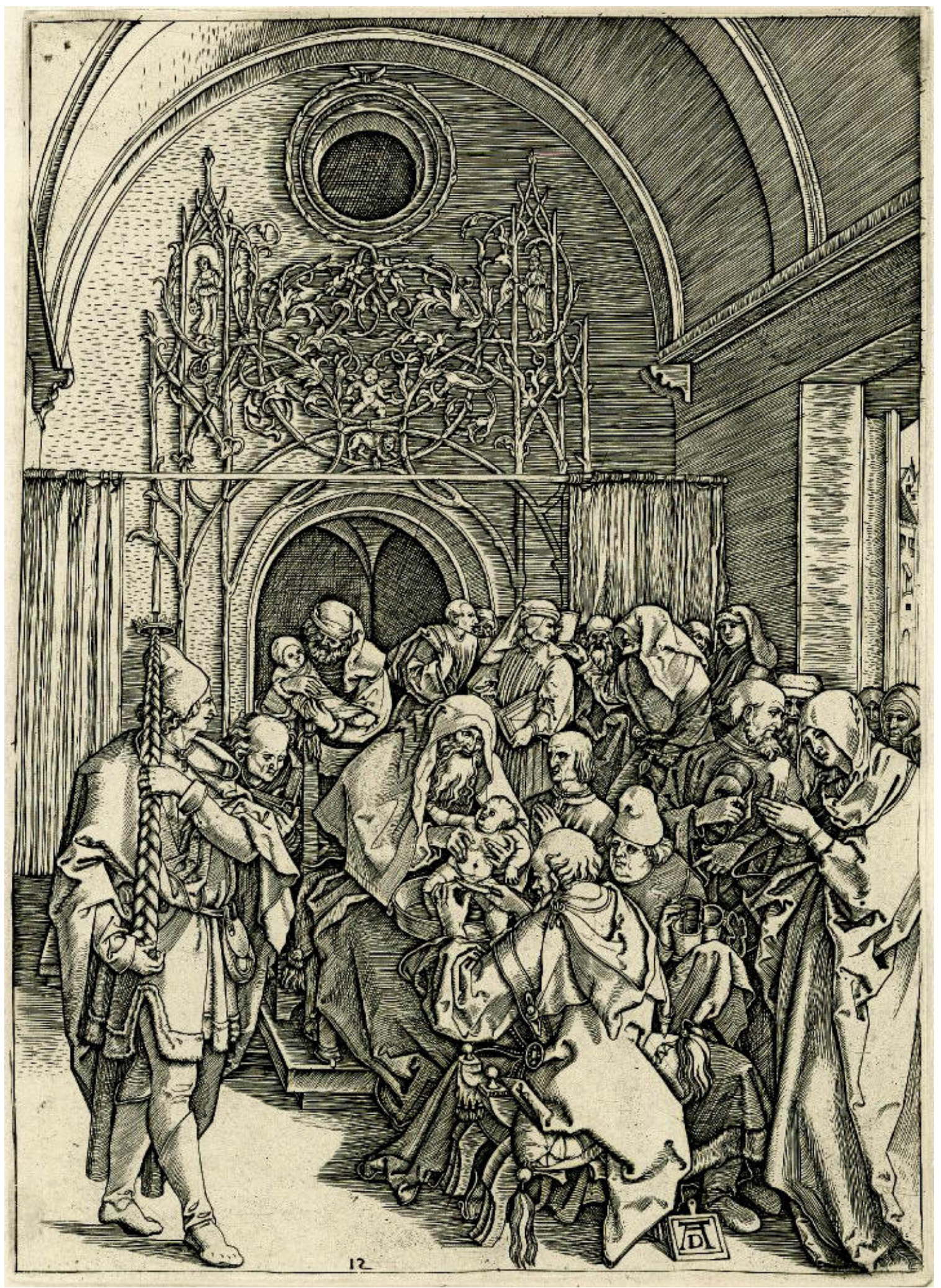

- Marcantonio Raimondi según Durero, La Circuncisión. Buril. 1508. 
Marcantonio realiza en torno a 1508 una estancia breve en Florencia en el camino que le lleva de Venecia a Roma, allí entra en contacto con la obra de Miguel Ángel y en particular con el cartón perdido de La Batalla de Cascina en el Palacio de la Signoria. En este se representa a unos soldados florentinos sorprendidos por el enemigo pisano mientras se bañan en el Arno y que ante la alarma, trepan por la orilla del río hacia la batalla. Basándose en esta obra, Raimondi realizó dos estampas, importantes como testimonio de la obra perdida de Miguel Ángel y de la evolución estilística del grabador boloñés.

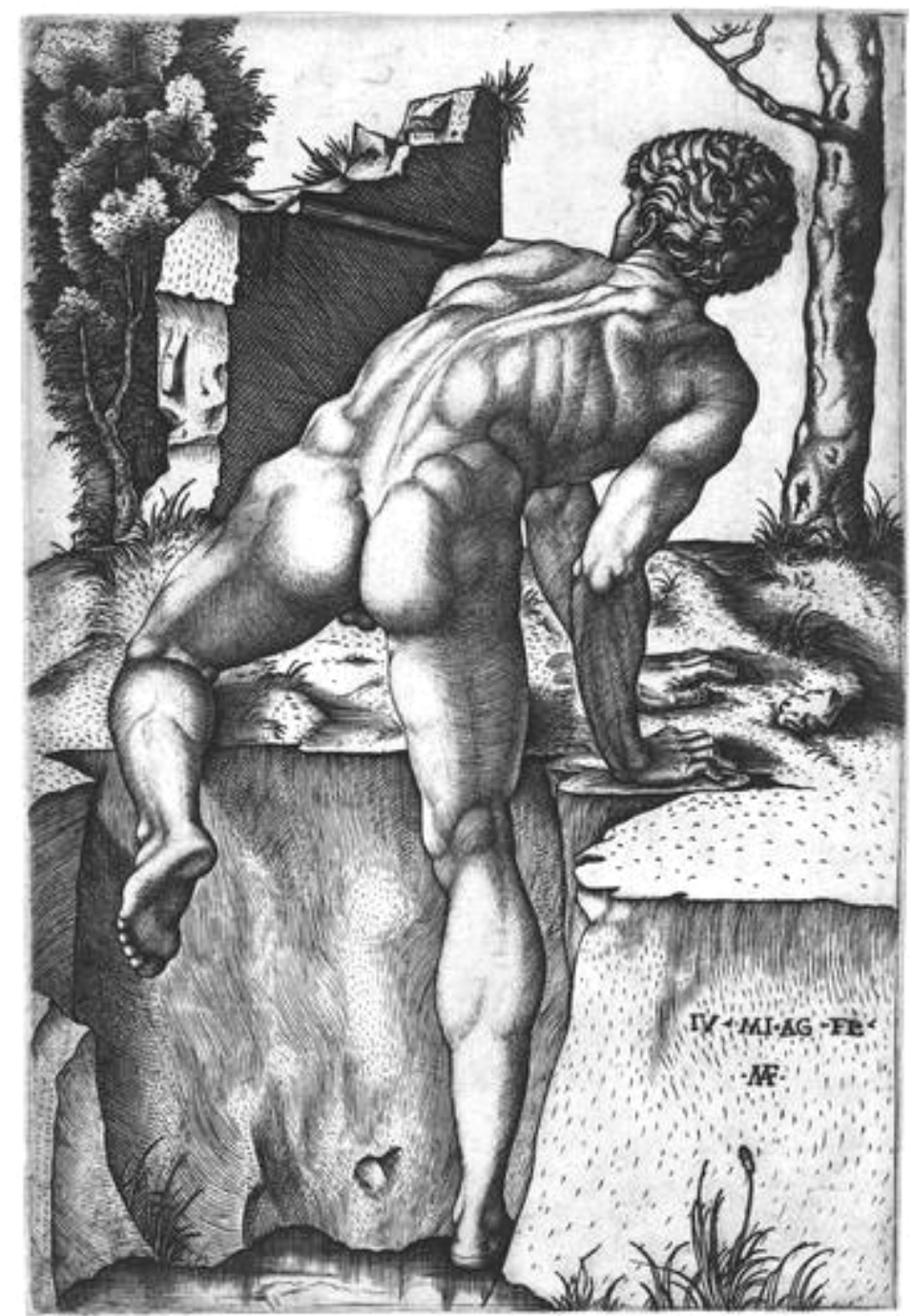

-Marcantonio Raimondi según Miguel Ángel. El Trepador. Buril. 1508-09

Seleccionó, entre el gran grupo de desnudos representados en el cartón, las figuras que le convenían para realizar en su trabajo una representación completa de la anatomía masculina. En el primer grabado, con un solo personaje, depende aun de la forma de grabar de Durero, la línea de buril está en relación con las xilografías del germano así como los amplios espacios blancos. En el modelado anatómico, una cierta dureza en el tratamiento del torso no consigue el mejor de los resultados, mientras que en las piernas ya empezamos a apreciar indicios de la codificación que seguirá desarrollando en la imagen siguiente en la que incluye tres figuras. 


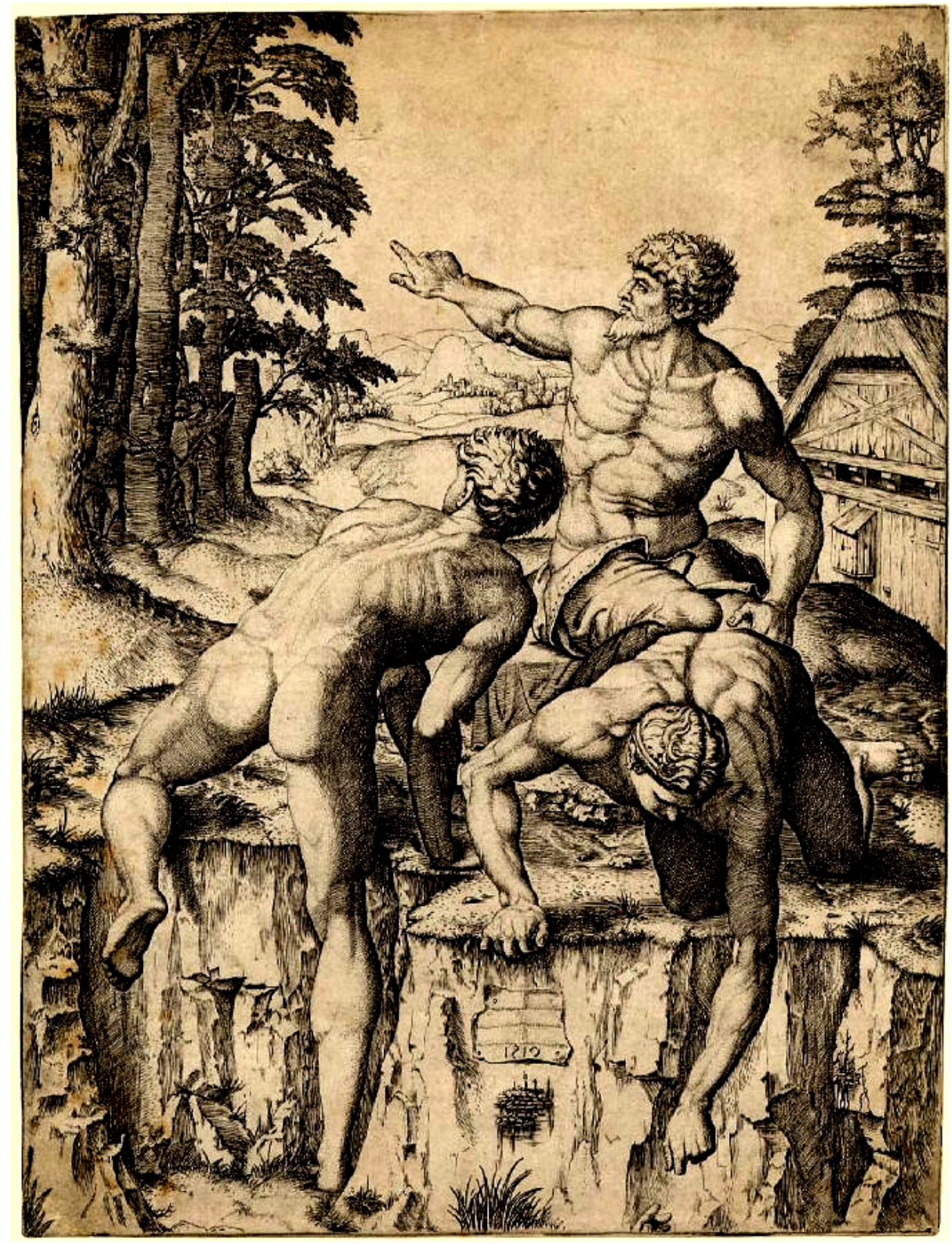

-Marcantonio Raimondi. Los Trepadores. Buril. 1510.

Fechado con exactitud en 1510, este grabado nos muestra un avance en el uso de líneas paralelas, sombreados entrecruzados y una cualidad atmosférica general mayor al incrementarse las transiciones tonales. El primer plano aparece mucho más elaborado y para el fondo, utiliza el de la obra de Lucas van Leyden, "Mahoma y el monje Sergio", con ligeras transformaciones.

En esta época empezó a experimentar con la imagen de van Leyden y con las sutilezas en el uso del buril que le son propias, esto le conduce a suavizar las líneas que conforman la musculatura de los soldados y a propiciar la sensación de profundidad. 


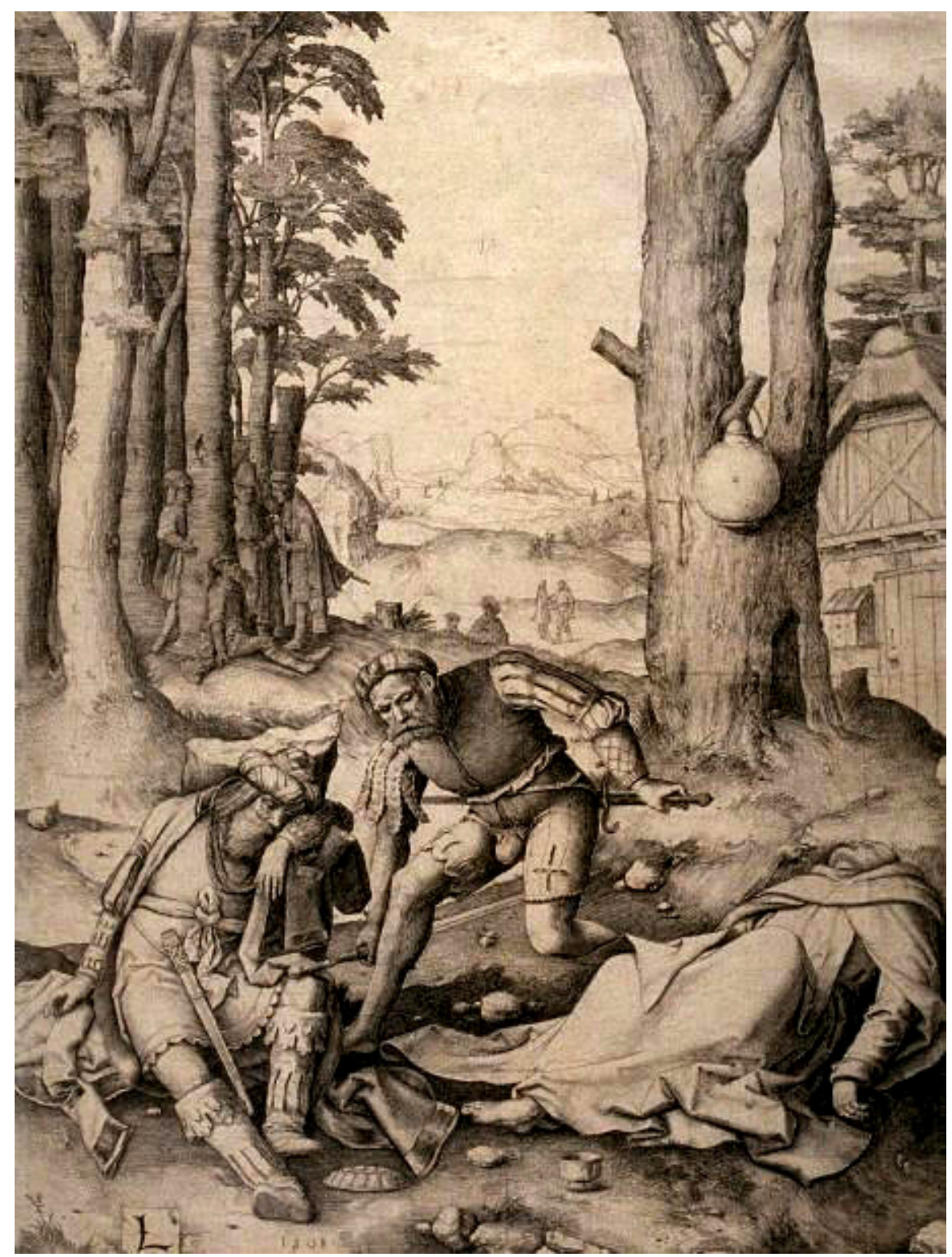

-Lucas van Leyden. Mahoma y el Monje Sergio. Buril. 1508.

Una asimilación mayor de las sutilezas y la suavidad presente en las obras de Lucas van Leyden entraba en contradicción con las características mismas de las de Raimondi. Su gusto por la monumentalidad y el carácter escultórico de sus figuras o el método aditivo de influencias diversas con el que trabajaba, se oponen a la concepción general de las obras del maestro holandés. No obstante, la obra de Raimondi en sus primeros tiempos de Roma se beneficiará del estudio y la utilización de las imágenes de van Leyden.

Poco se sabe de la llegada de Marcantonio Raimondi a Roma ni de cómo se inician sus relaciones con Rafael y su círculo de trabajo. Lo que es seguro es que grabó algunas imágenes con origen en su obra y como consecuencia fue contactado para seguir haciéndolo. Según Vasari, un ayudante del maestro, el Baviera, se relacionaría y asociaría con él para producir y comercializar las imágenes de Rafael y está documentado que en 1511, Marcantonio está ya formando parte del círculo rafaelesco. 


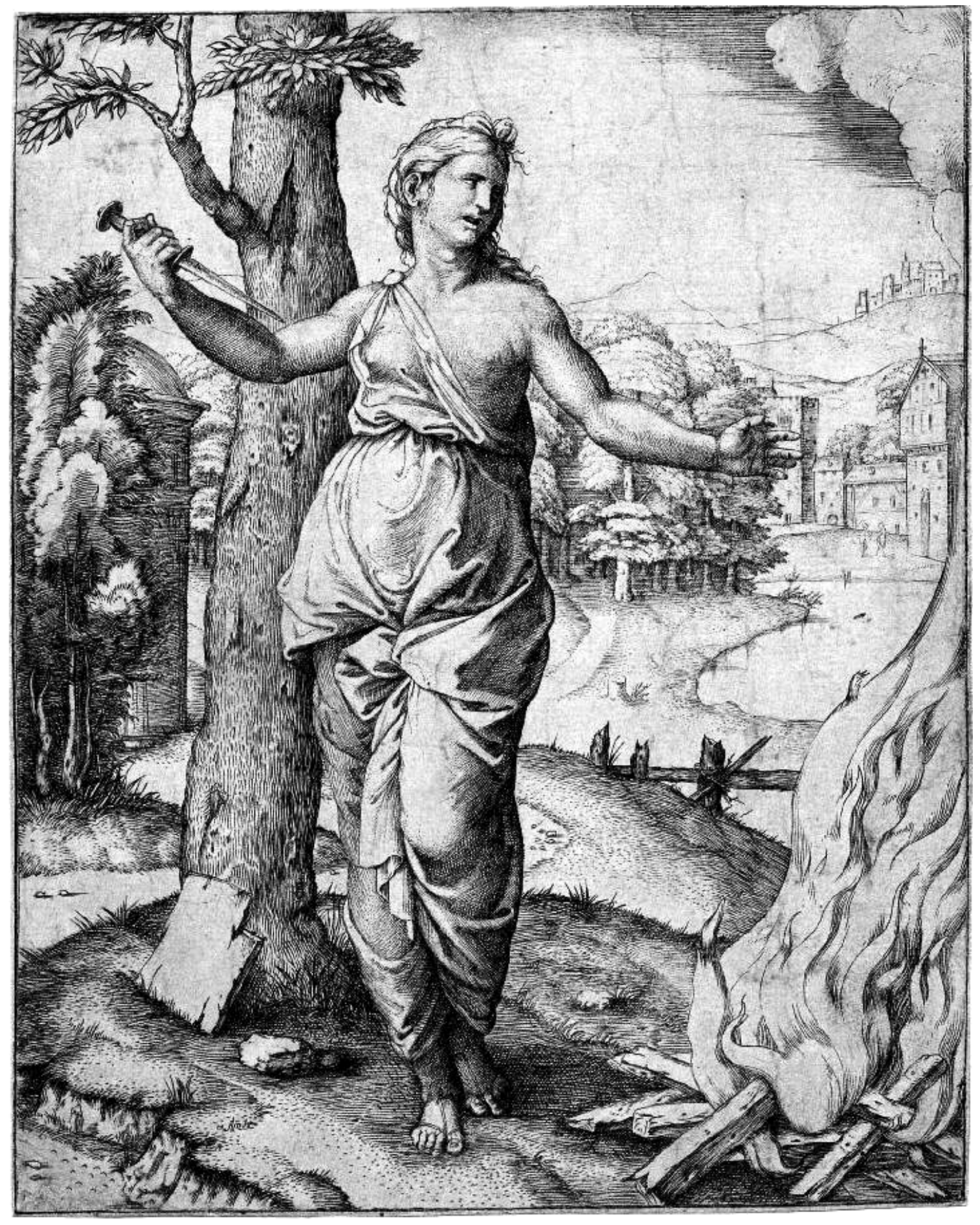

- Marcantonio Raimondi según Rafael. Dido. Buril. 1510-11

Para narrar el suicidio de la mítica reina de Cartago, Raimondi recurre al mismo esquema formal que en su "Venus secándose el cabello" (1507) de la época veneciana. Una figura femenina en pie ejecutando una acción. A su izquierda en el término medio aparece un árbol y en la lejanía un paisaje. El avance técnico y estilístico que se aprecia es enorme, en los pocos años transcurridos ha conseguido una casi perfecta 
integración de los elementos que forman la composición, figura de origen rafaelesco en un paisaje sacado de van Leyden. La codificación gráfica está casi desarrollada por completo y su estilo romano se definirá más aun en una obra del mismo año o ligeramente posterior, "Lucrecia". Fueron al parecer estos trabajos primeros realizados según la obra de Rafael los que llamarían la atención de este y que finalmente le llevarían a formar parte del grupo de trabajo del maestro.

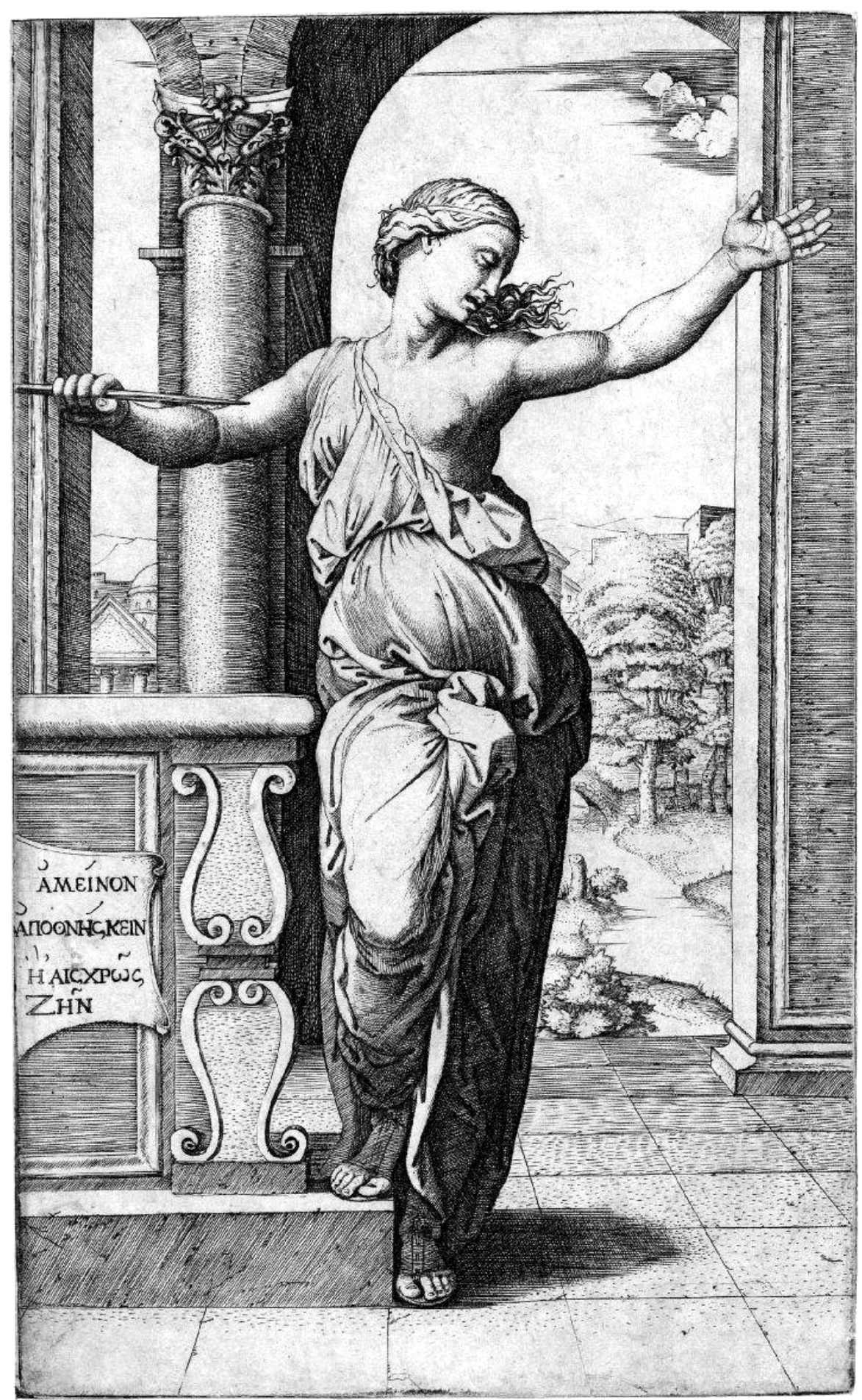

- Marcantonio Raimondi según Rafael. Lucrecia. Buril. 1511. 


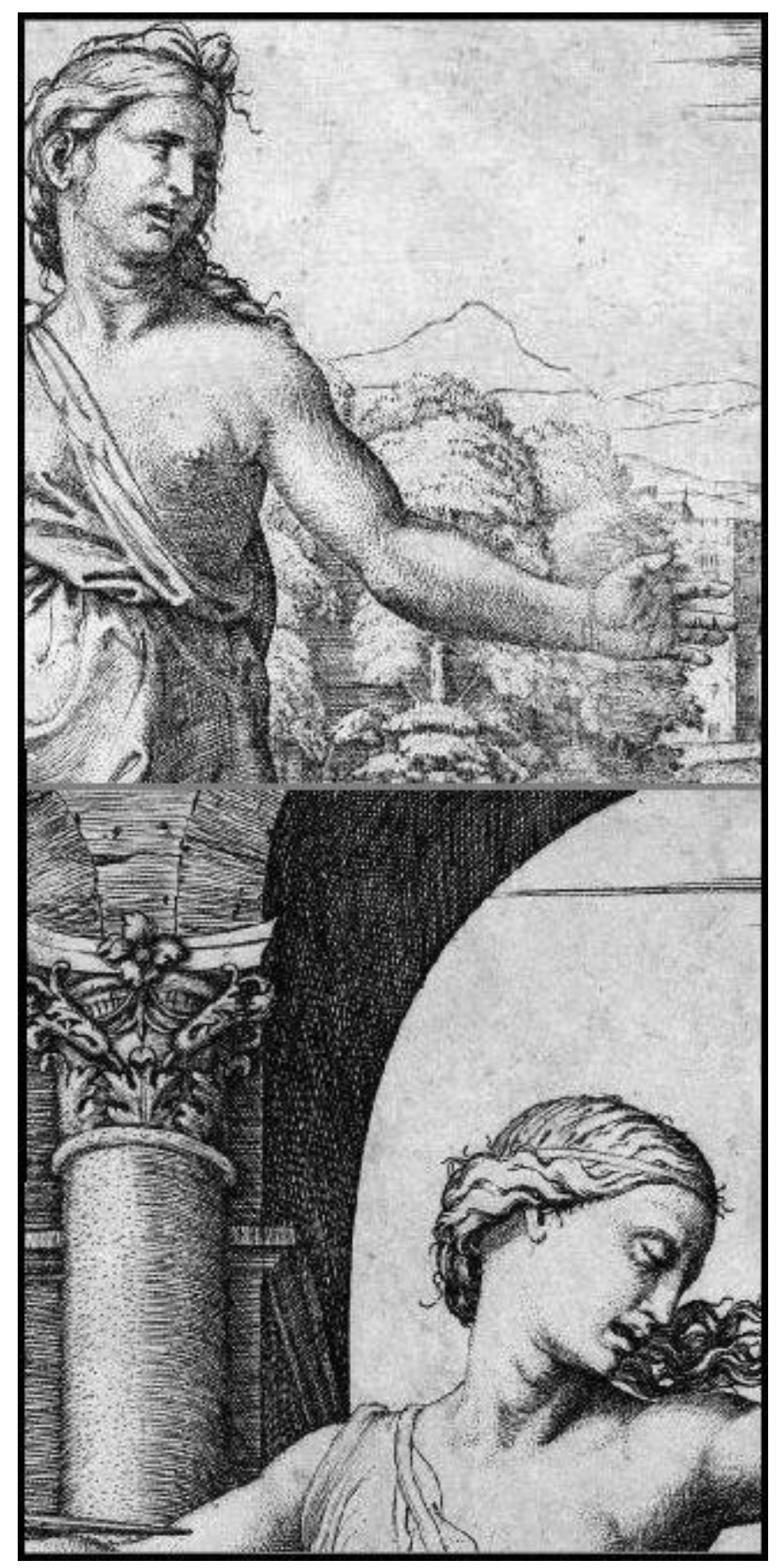

- Dido y Lucrecia, fragmentos. Codificación gráfica.

Temática plenamente clásica, monumentalidad de las figuras, aparición de elementos arquitectónicos renacentistas, disminución o desaparición del fuerte perfilado lineal de los contornos y modelado de volúmenes con los característicos rayados paralelos de diferente separación, entrecruzados de distinta densidad para las zonas oscuras y puntos o pequeños trazos delicados para las transiciones tonales.

Para estas fechas, las características del modo romano de trabajar en Marcantonio Raimondi, se han definido y consolidado por completo. 
Desde 1511, año en el que ha empezado su colaboración con Rafael, Marcantonio cuenta ya con un taller y ayudantes para llevar a cabo sus proyectos. Marco Dente da Ravenna y Agostino dei Musi, conocido como Agostino Veneciano son los más destacados. Realizarían obras propias y copias de los grabados de Marcantonio según Rafael y otros artistas activos en Roma .

Poco sabemos de las relaciones laborales entre los miembros del equipo de Raimondi y el de Rafael. Tampoco de quien tomaba la iniciativa en la elección de las imágenes a grabar ni del propietario final de las planchas, probablemente Raimondi, aunque tras la muerte de Rafael en el 1520 y el Saco de Roma en 1527, Baviera aparece citado como poseedor de un número indeterminado de matrices.
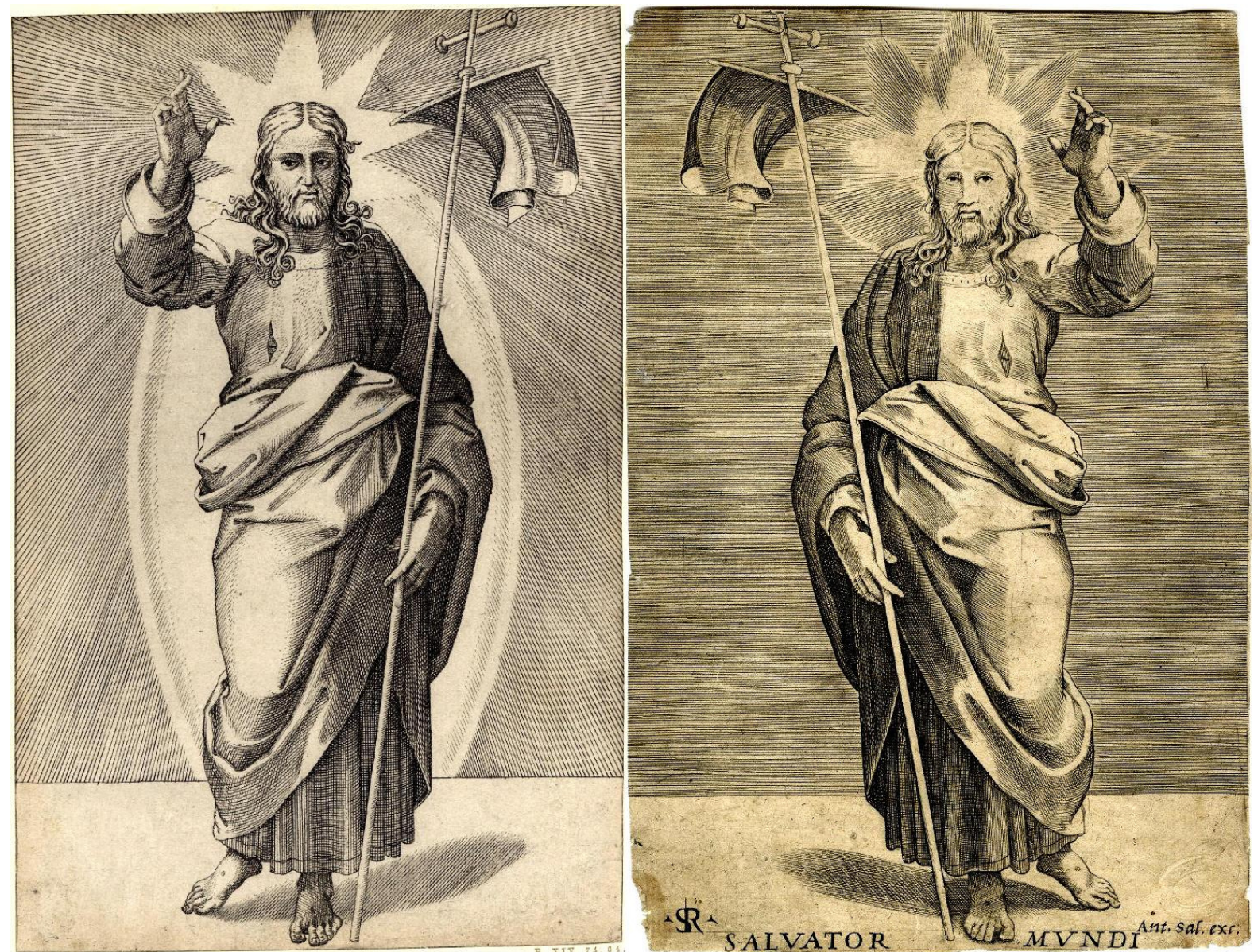

-Marcantonio Raimondi según Rafael y Marco Dente da Ravenna según Marcantonio según Rafael. Cristo Salvador. 1510-1527.

En muchas ocasiones, los dibujos en los que Raimondi se basa para efectuar sus grabados son obras de Rafael copiadas por miembros de su equipo, pero no siempre. En 1511-12, realiza la primera versión de "La Masacre de los Inocentes" , "avec le chicot" (con el pequeño pino del ángulo superior derecho) que es una de las obras más sofisticadas surgidas de la colaboración entre estos artistas. Hay consenso sobre la autoría directa de Rafael del original en que se basó la estampa y quedan al menos 6 dibujos del maestro relacionados con esta imagen. 


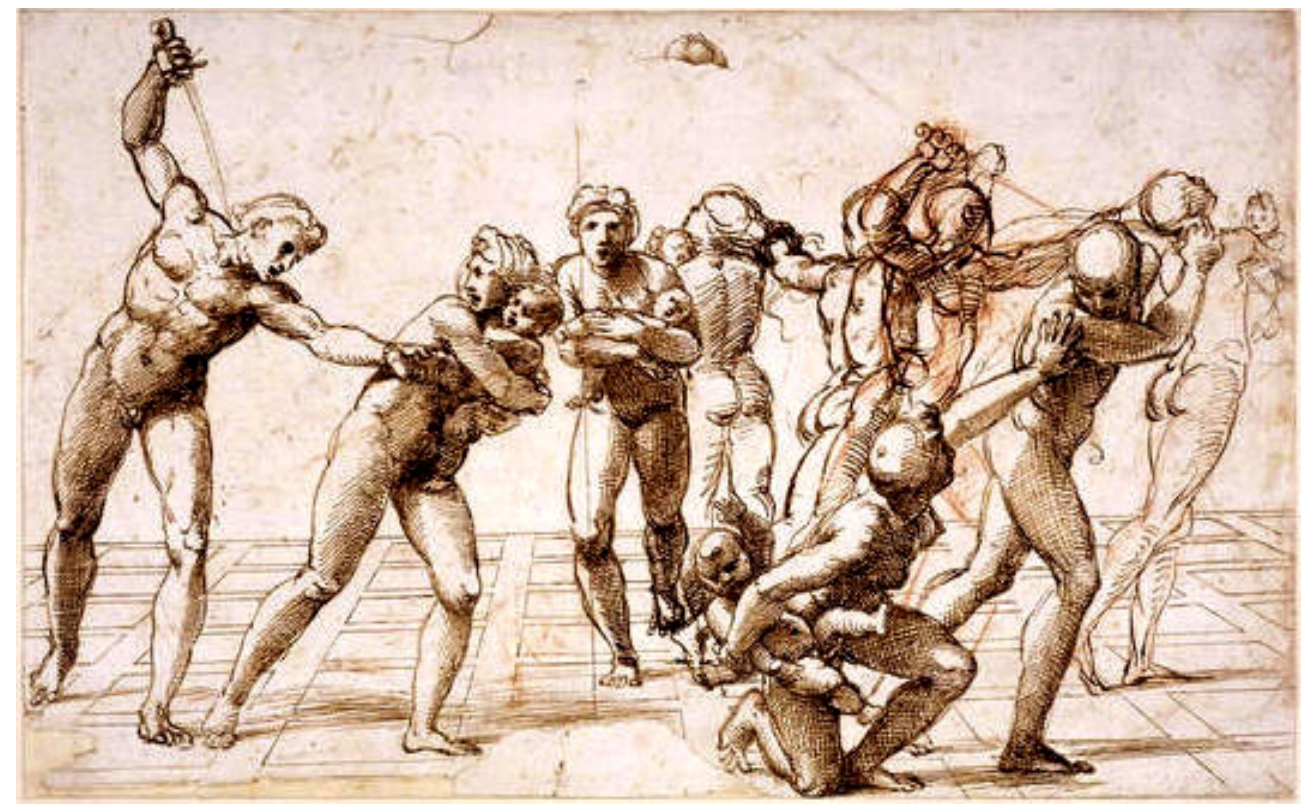

- La Matanza de los Inocentes. Uno de los dibujos originales de Rafael que subsiste.

En esta obra Raimondi consigue un mejor equilibrio entre las figuras y el fondo urbano en el que se insertan y el dominio técnico que haría de esta estampa un éxito inmediato. Posiblemente por esta razón y por el deterioro que la obtención de un gran número de copias produciría en la matriz, vuelve a grabar la misma imagen con pequeñas diferencias de estilo que nos orientan sobre la datación posterior de esta última, llamada "sans le chicot" (sin el pinito) para diferenciarla de la primera.

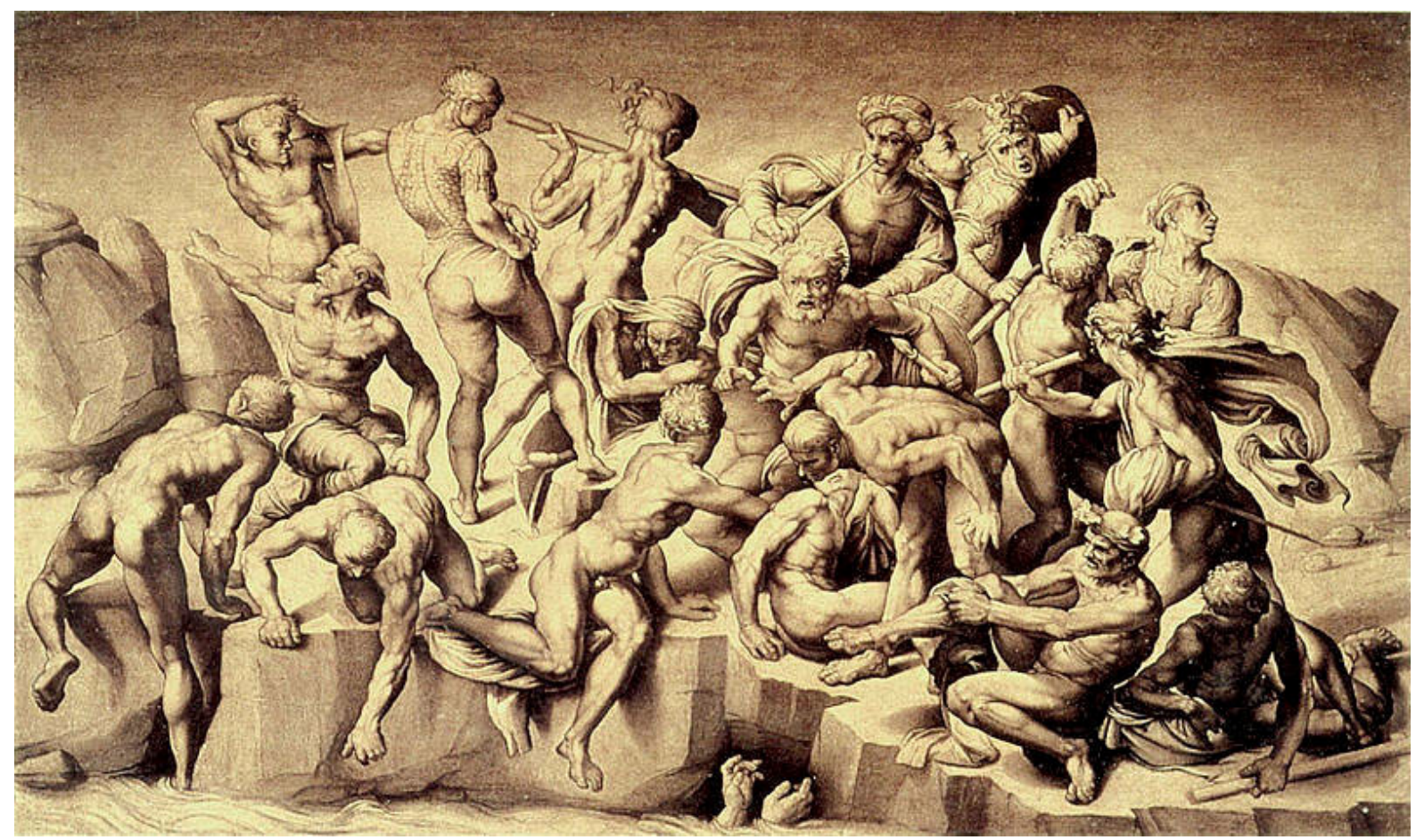

-Bastiano de Sangallo, dibujo basado en el cartón de Miguel Angel para "La Batalla de Cascina". ca.1542 
El dibujo de Rafael está directamente relacionado con la estatuaria clásica y con el cartón de Miguel Angel sobre La Batalla de Cascina, influencias que también había recibido Raimondi. Los resultados sin duda se beneficiaron de esta comunidad de intereses. Las figuras, tanto en el tratamiento anatómico como en la composición, que gira en torno a un eje central, derivan igualmente del estudio de esta obra.
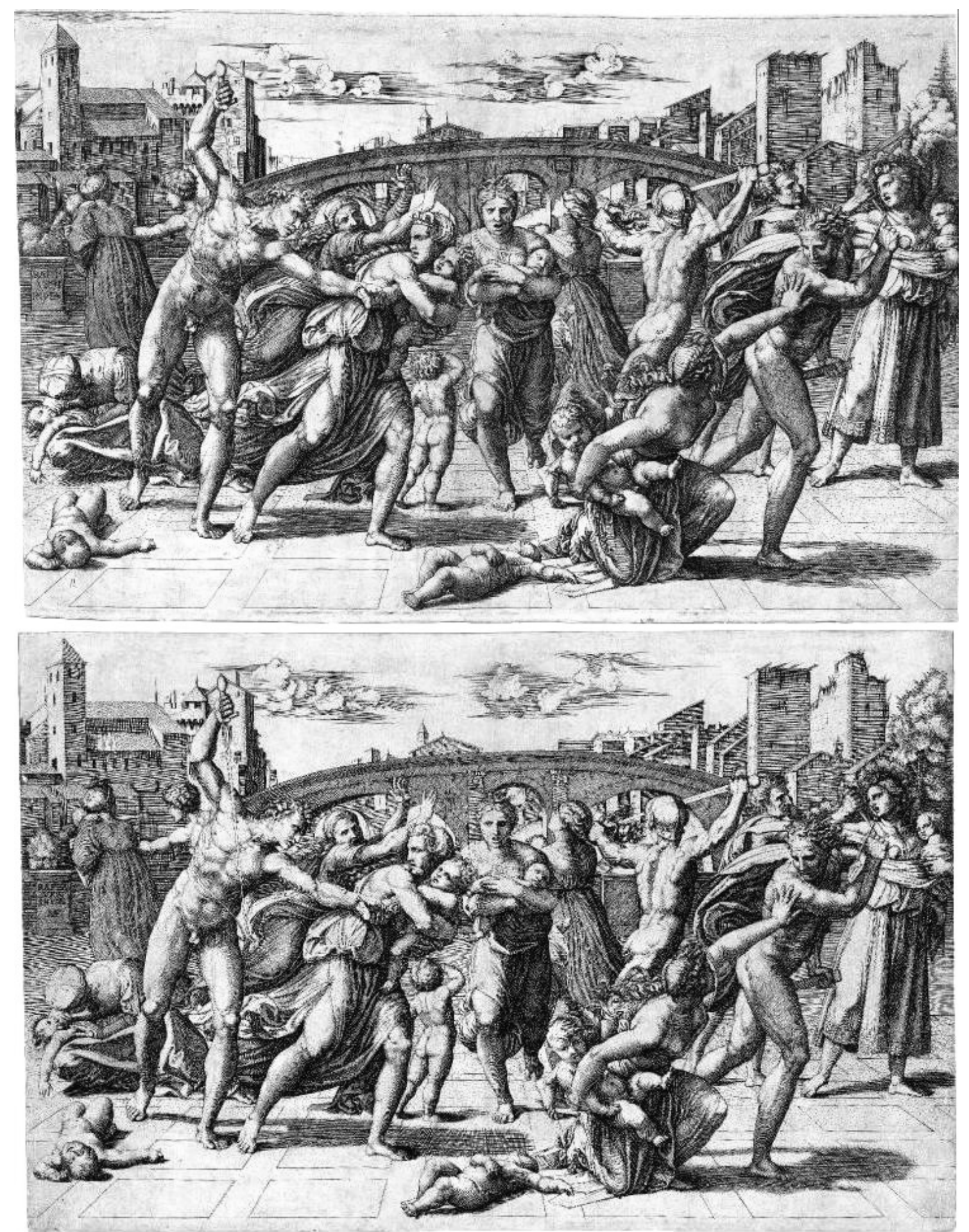

- Marcantonio Raimondi , La Masacre de los Inocentes. 1511 y 1512 ?. 
En la segunda versión, consigue reflejar una luz más uniforme que suaviza contrastes y unifica la imagen. Los trazos son más amplios y audaces, menos definidos y mejor adaptados a los volúmenes musculares.

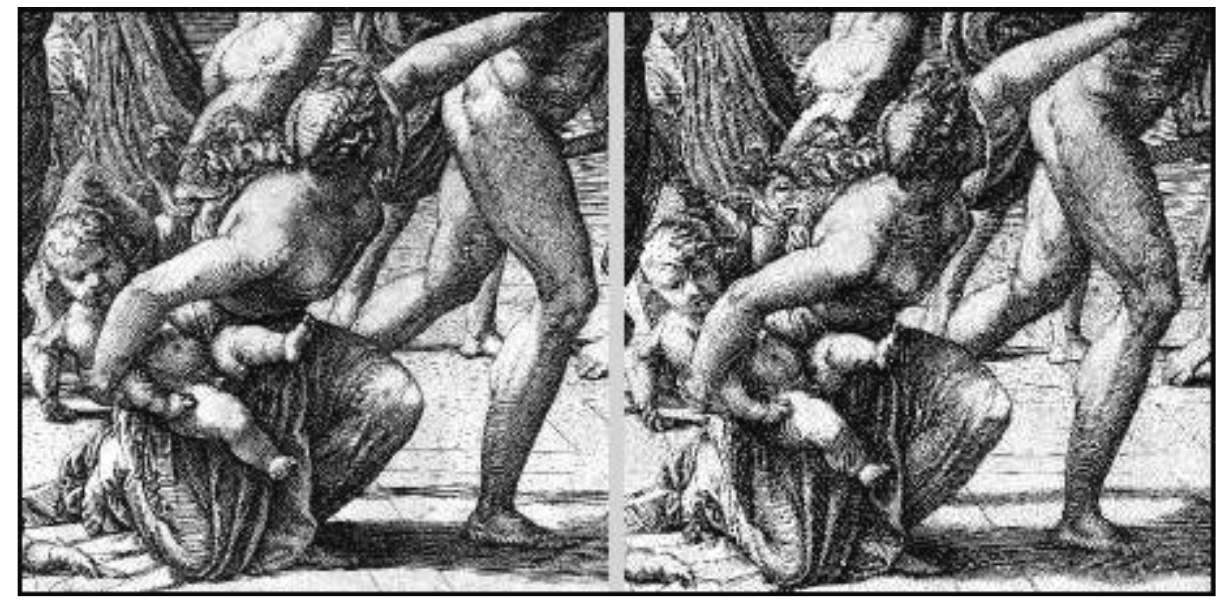

- Detalles de La Masacre de los Inocentes. Versiones de 1511 y 1512 ?.

El mercado de Marcantonio Raimondi parece responder a varios propósitos. En los trabajos más elaborados, cuando parte de dibujos de la propia mano de Rafael, como es el caso de la "Masacre" y más adelante del "Quos Ego" y "El Juicio de Paris", pudiera atender a encargos específicos de coleccionistas que buscaban obras de primera calidad y al deseo de Rafael de difundir y promocionar su obra. Cuando acomete las series genéricas de santos, apóstoles, virtudes, dioses paganos 0 caballeros romanos, sirve a otros fines. El devocional, en el caso de los santos y el mercado de los propios artistas que precisan modelos concretos para elaborar las composiciones que constantemente demanda la clientela de ese tiempo, la Iglesia, la nobleza y los profesionales interesados en las nuevas formas artísticas.

Con respecto a los dibujos originales que interpreta, ocasionalmente cambia la escala 0 invierte el sentido, pero en lo que respecta a las figuras no hace nunca cambios sustanciales. Y ya desde este momento, la integración de los fondos, paisajes o arquitecturas de diferente origen, está perfeccionada al máximo.

Desde esta fecha, 1511-12 y hasta el Saco de Roma en 1527, el arte de Marcantonio pasará por una serie de fases de características diferenciadas. En esta primera, en la que produce la "Masacre" o el "Adán y Eva", aun aparecen ciertas partes planas en el modelado o confusión en las líneas curvadas.

En "Adán y Eva", la composición alcanza un equilibrio extraordinario, los árboles del primer término se curvan siguiendo las posturas de las figuras de hermoso tratamiento escultórico. Lo extraño del paisaje de fondo, un conjunto arquitectónico inequívocamente nórdico en pleno jardín del Edén, se pasa por alto gracias a la integración visual que consigue al grabarlo con líneas mucho más suaves. Sin embargo aun aparecen algunas zonas del sombreado de rectas paralelas en hombro, pecho y brazo izquierdo de Adán que aplanan la definición de su musculatura. 


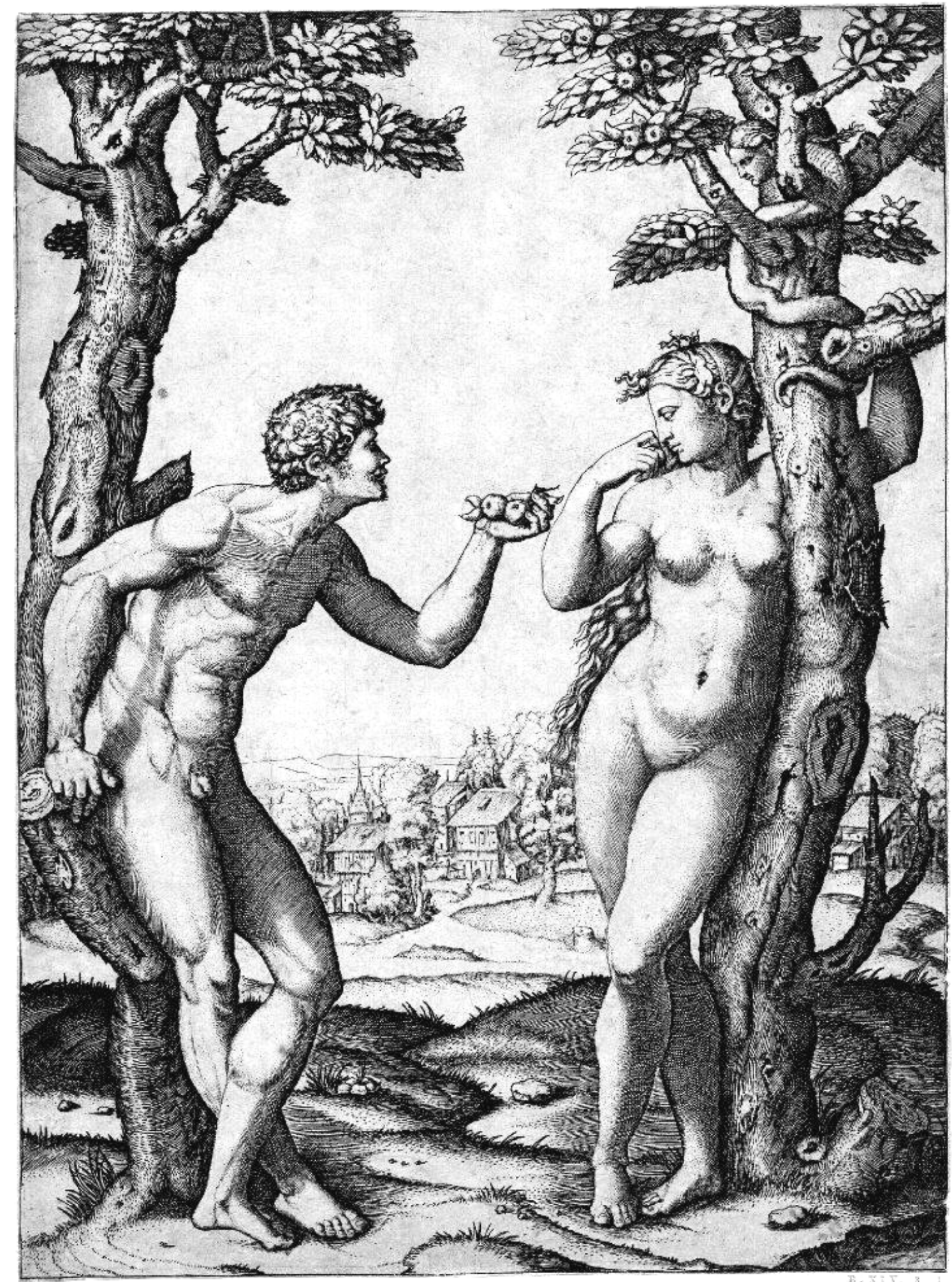

- Marcantonio Raimondi según Rafael, Adán y Eva. Buril. 1511-12. 


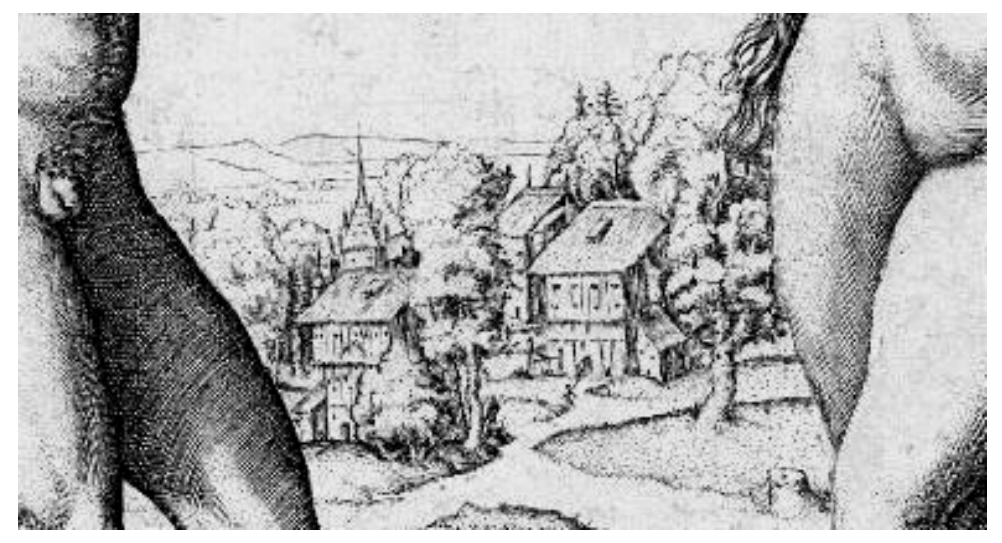

- Detalle del paisaje del fondo en "Adán y Eva".

Más tarde, 1513-15, tanto en la obra de Rafael como en la de Raimondi aumenta el dramatismo. Restringe las transiciones tonales incrementando los contrastes de luz y sombra y los personajes, quizás por la influencia en Roma de la estética de Miguel Ángel, ganan en peso y gesticulación.

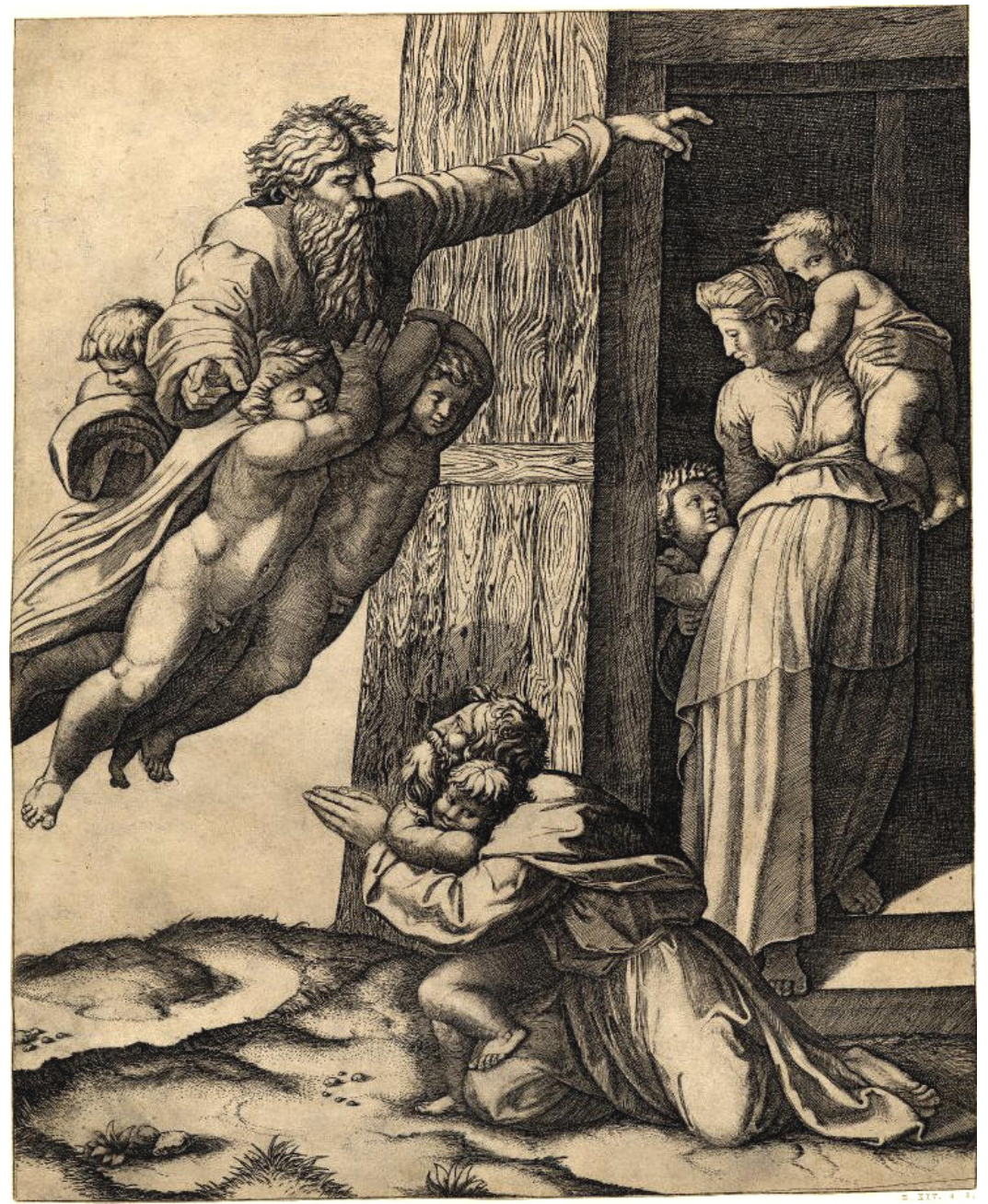

- Marcantonio Raimondi según Rafael. Aparición de Dios a Noé. Buril. 1513-15. 


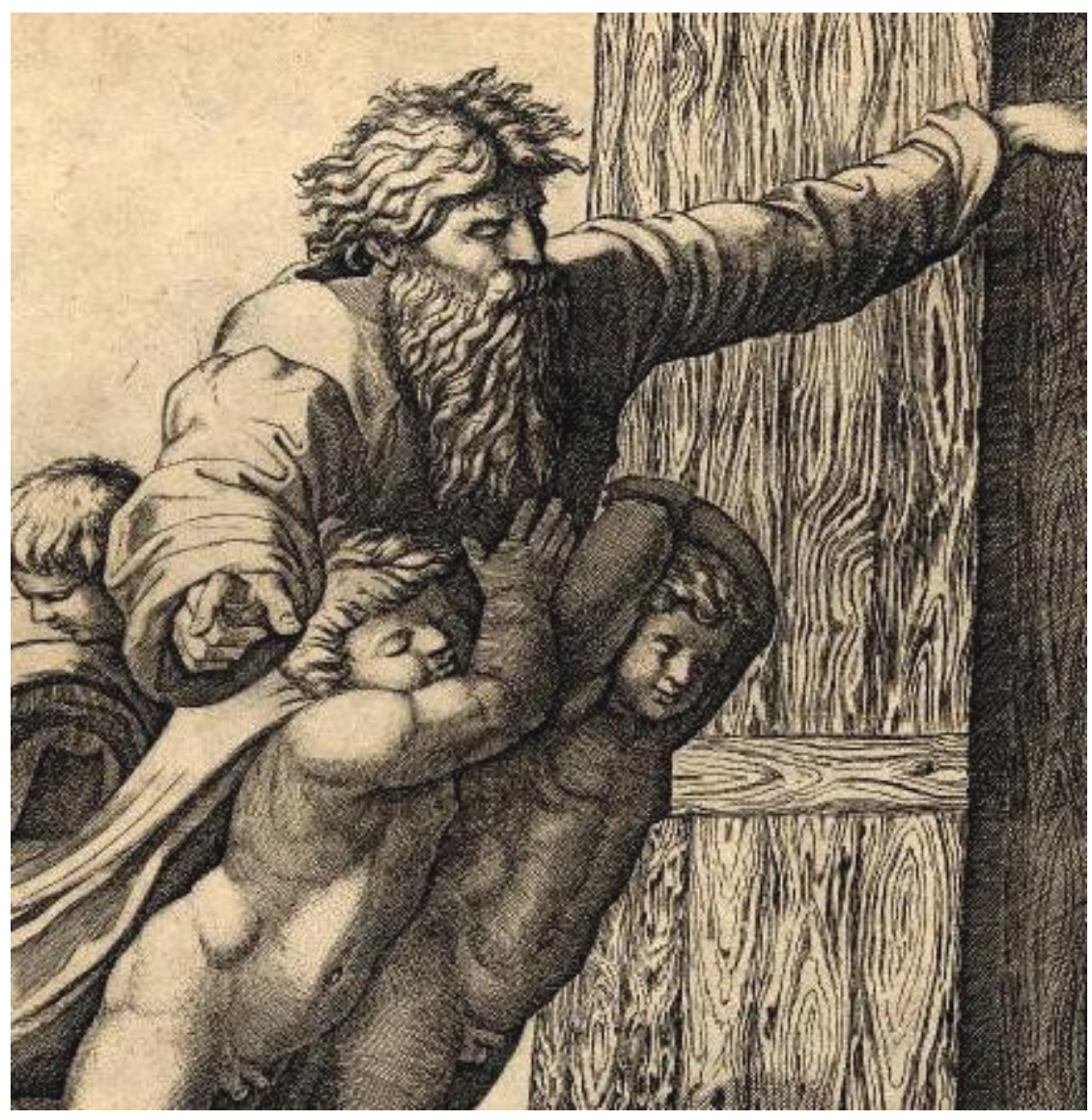

- Aparición de Dios a Noé. Detalle. 1513-15.

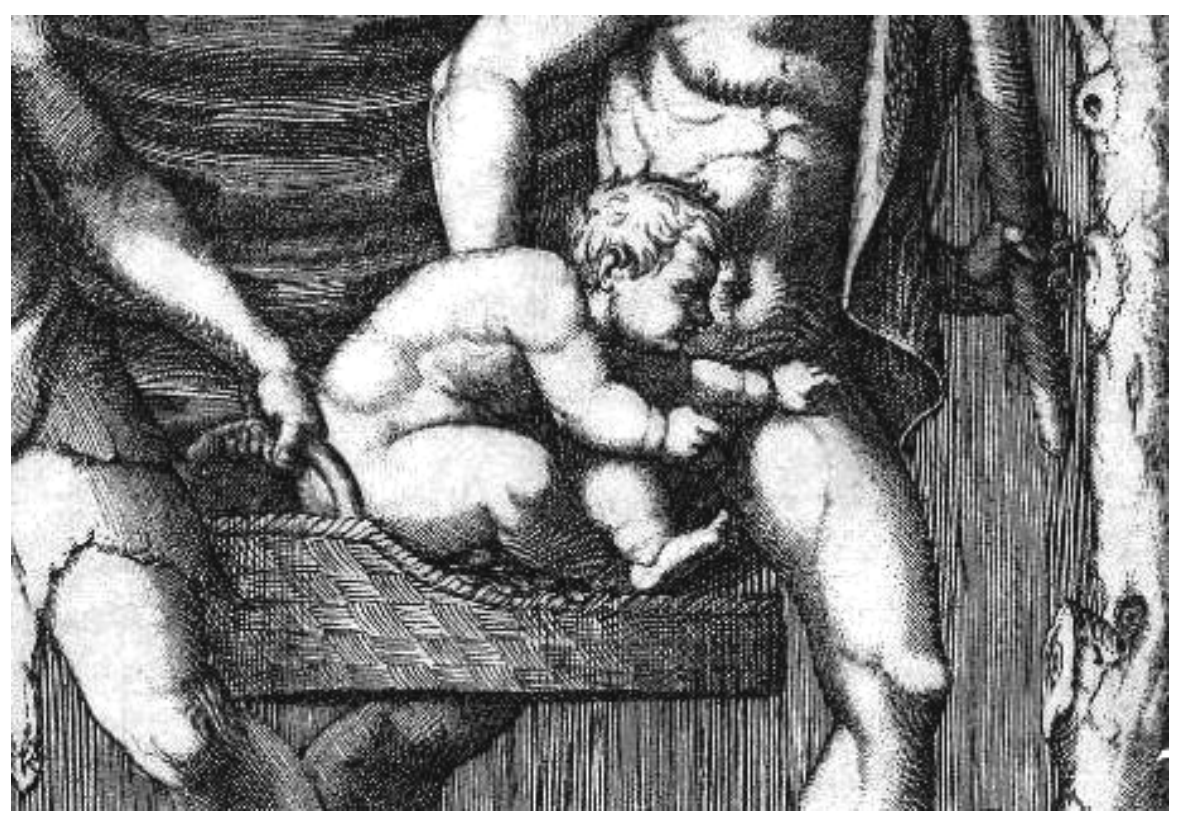

- Dos Faunos llevando un niño en un cesto. Detalle. 1513-15.

Poco después de estas fechas, en la obra de Raimondi se potencia notablemente la variedad tonal, puesto que empieza a grabar partiendo de aguadas que así lo exigen. 


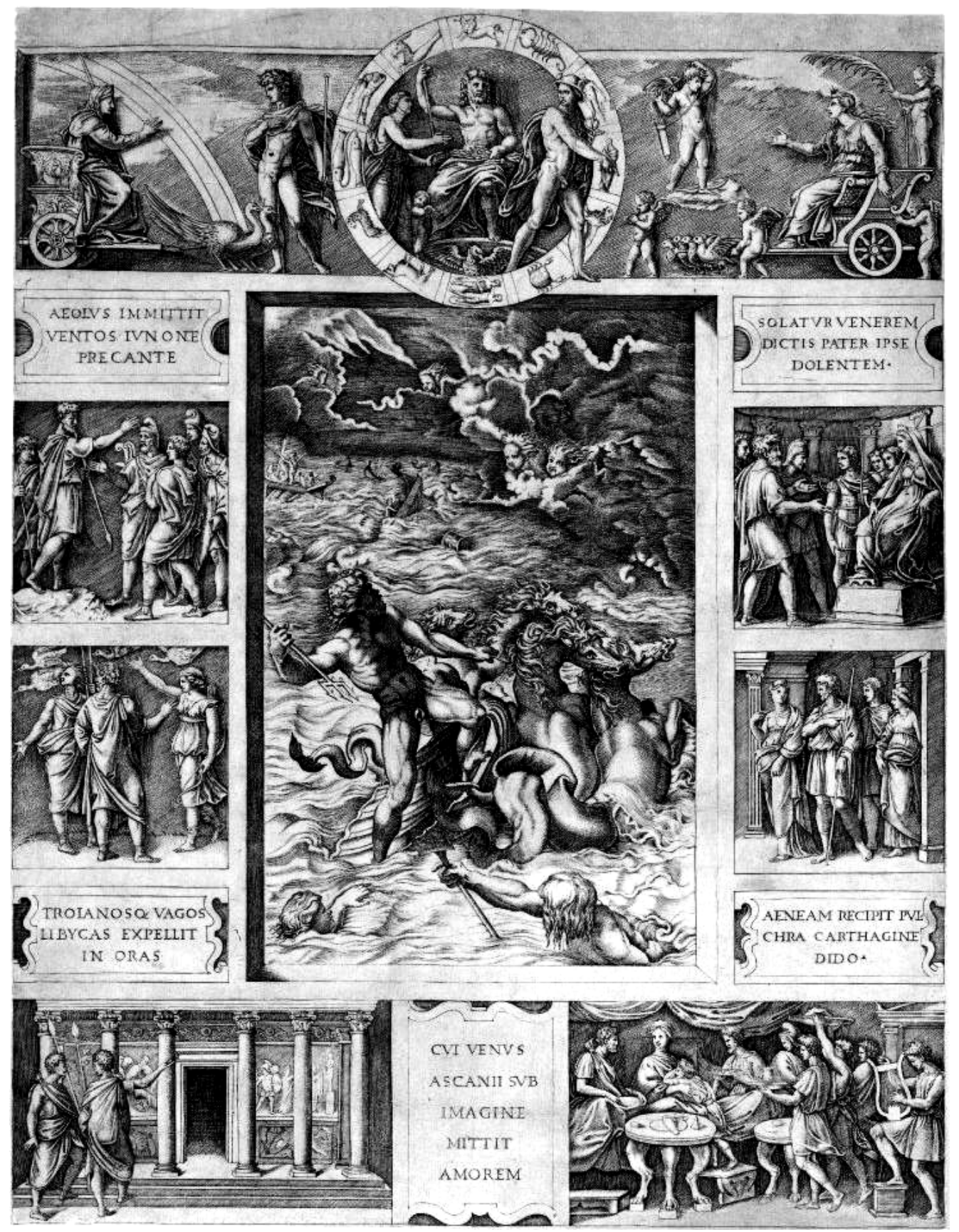

-Marcantonio Raimondi según Rafael. Quos Ego. Buril. 1515-16.

Esta obra, que parte de un original de Rafael, reproduce el esquema formal de un cierto tipo de relieve romano del siglo I. La Historia, procedente de la Eneida, habla del triunfo de Poseidón sobre las fuerzas tempestuosas de la Naturaleza, estableciendo un paralelismo entre el dios y el Papa Julio II y su triunfo sobre las tropas francesas en esas fechas. El tratamiento técnico de la imagen responde al deseo tanto de Rafael como de Raimondi de reconstruir el arte pictórico de la Roma antigua partiendo de la interpretación de relieves escultóricos. En la magnífica sección central con Poseidón iluminado por la dramática luz de los relámpagos, Marcantonio consigue con el buril un trabajo denso y delicado que procura una representación unificada de la atmósfera general. 


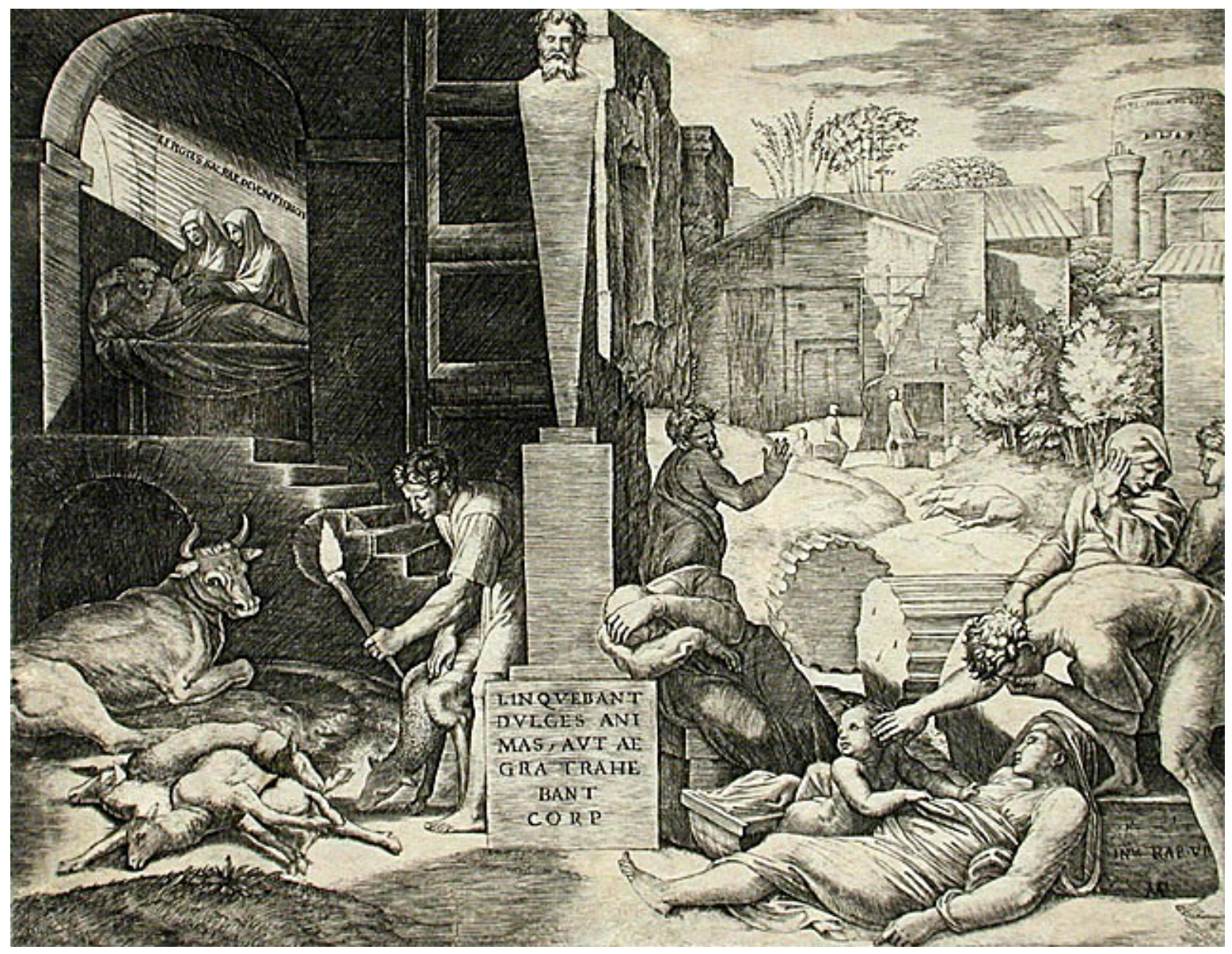

- Marcantonio Raimondi según Rafael. Il Morbetto. Buril. 1515-16.

Profundización en el claroscuro. El entorno espacial que acoge a las figuras es esencial para definirlas. Interés en la creación de atmósferas densas o sombrías. Entrecruzados sistemáticos, secuencias de curvas paralelas y punteados que definen perfectamente las anatomías y las transiciones.

En Il Morbetto (La Plaguita), llamado así por el pequeño tamaño de la estampa, trabaja con una escena nocturna, refleja la luz artificial de la antorcha y la natural del exterior más neutra y fantasmal. Como en el "Sueño de Rafael" (1507-08) ejecutada en Venecia, parte la escena en dos secciones de iluminación radicalmente opuesta. Los resultados de Il Morbetto son un claro exponente del gran salto técnico dado en esta fase romana de su desarrollo artístico.

A partir de 1516-17 alcanza su etapa de pleno desarrollo. No solo en los proyectos más ambiciosos si no en toda la obra, su capacidad para representar los intereses que siempre le han dirigido le hacen conseguir grandes resultados, tanto en pequeño formato como en escalas mayores.

Una serie de obras como Galatea, El Juicio de Paris o David y Goliat, pertenecientes a este periodo, se encuentran entre las mejores y más influyentes creaciones de Marcantonio Raimondi. 


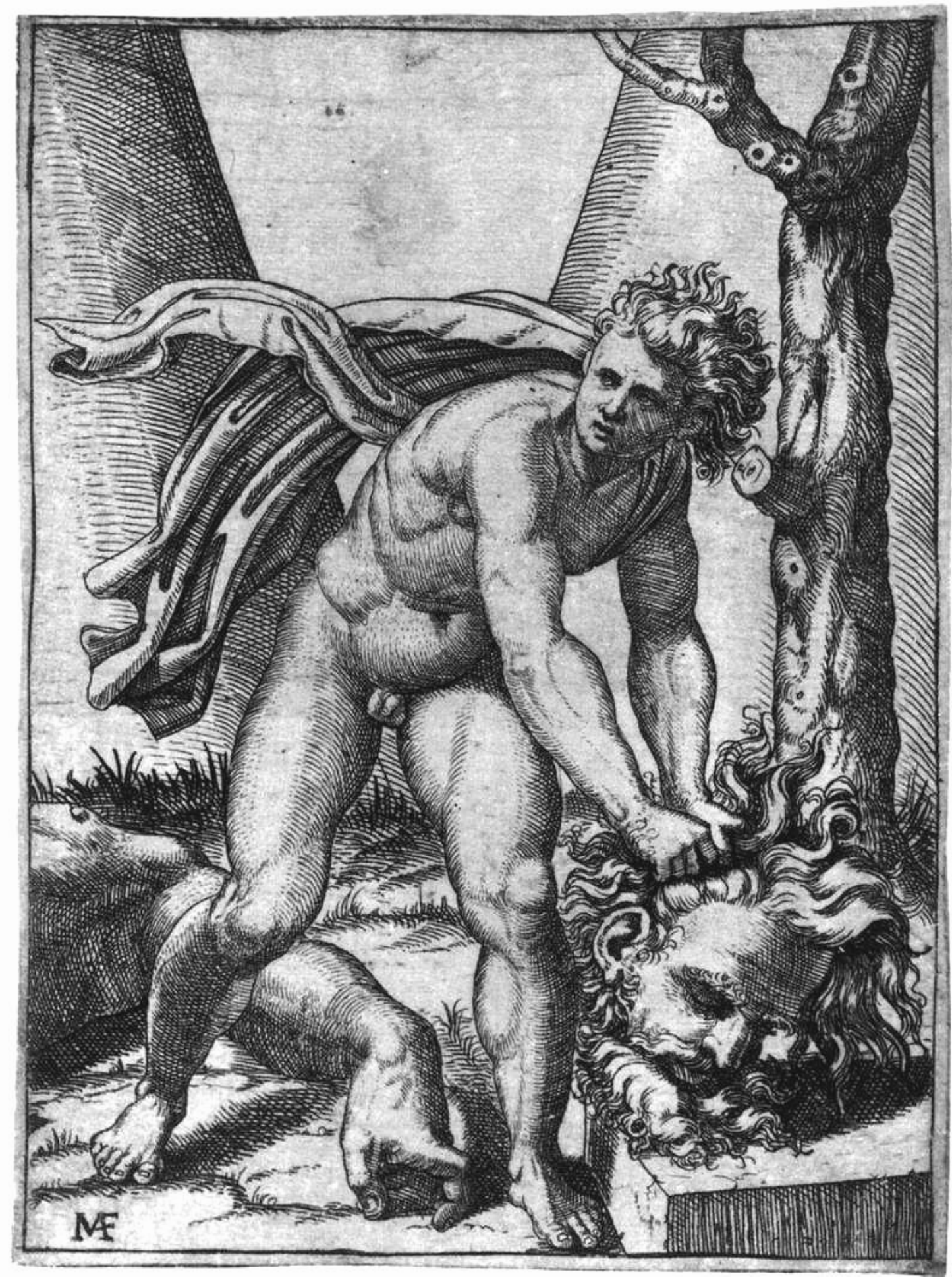

- Marcantonio Raimondi. David y Goliat. Buril. 1515-16.

Las grandes similitudes con las figuras de la bóveda de la capilla Sixtina, nos permiten pensar que pudiera haber ejecutado este grabado según un original de Miguel Ángel. Las pequeñas dimensiones de la estampa, $114 \times 81 \mathrm{~mm}$, , no son inconveniente para que la soltura de trazado y la armonía técnica consigan el mejor de los resultados. 


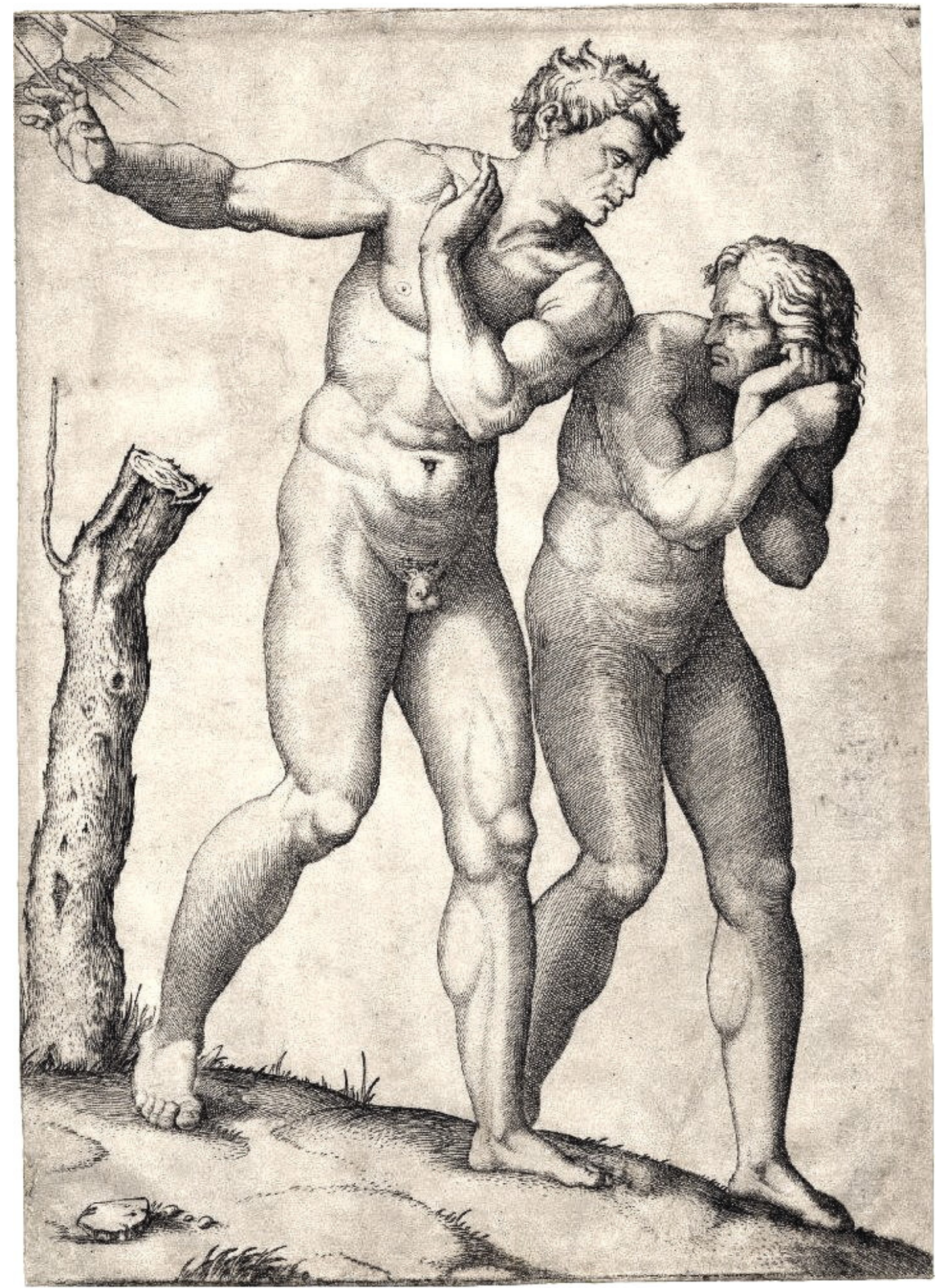

-Marcantonio Raimondi según Miguel Ángel. Expulsión del Paraiso . Buril. 1515-20. 


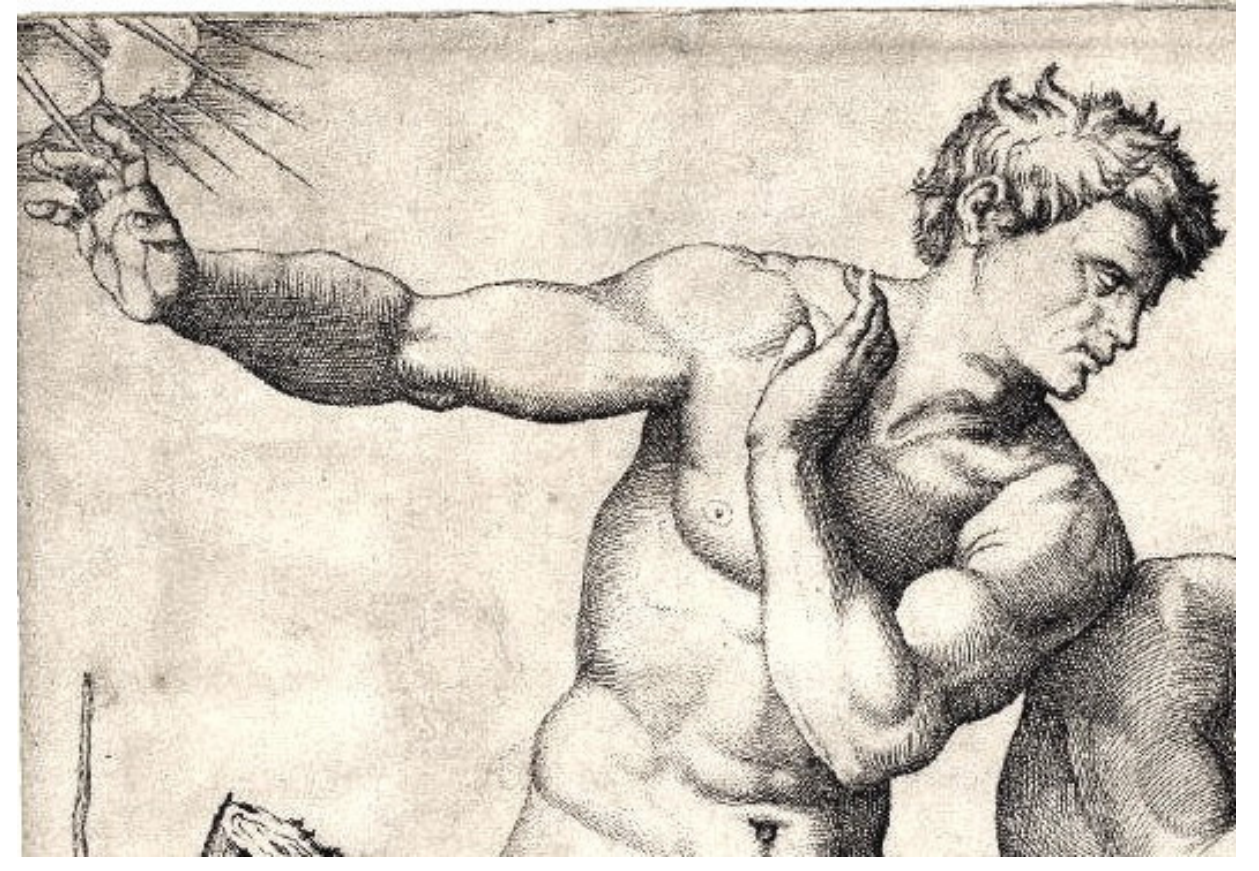

- Marcantonio Raimondi según Miguel Ángel. La expulsión del Paraíso, detalle.

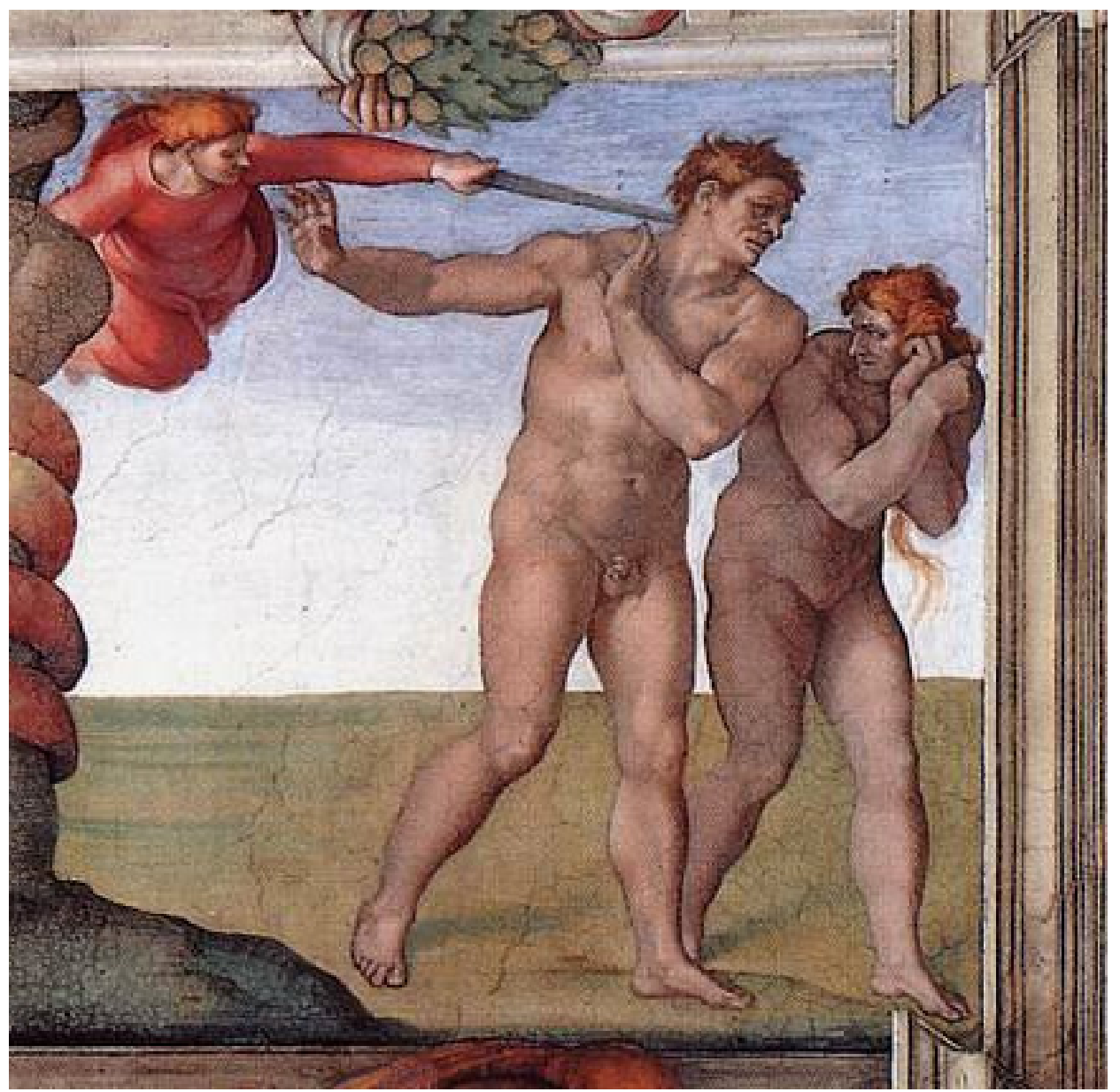

- Miguel Ángel. Bóveda de la Capilla Sixtina. Detalle de Adán y Eva. 1508-12. 
En "La Expulsión del Paraíso" al igual que en el fresco de El Vaticano, Raimondi recorta las figuras de Adán y Eva sobre un fondo vacío, allá el cielo azul y aquí el papel limpio. Toda la atención se centra en la iluminación de las figuras que potencia su monumentalidad representada mediante su eficaz codificación gráfica.

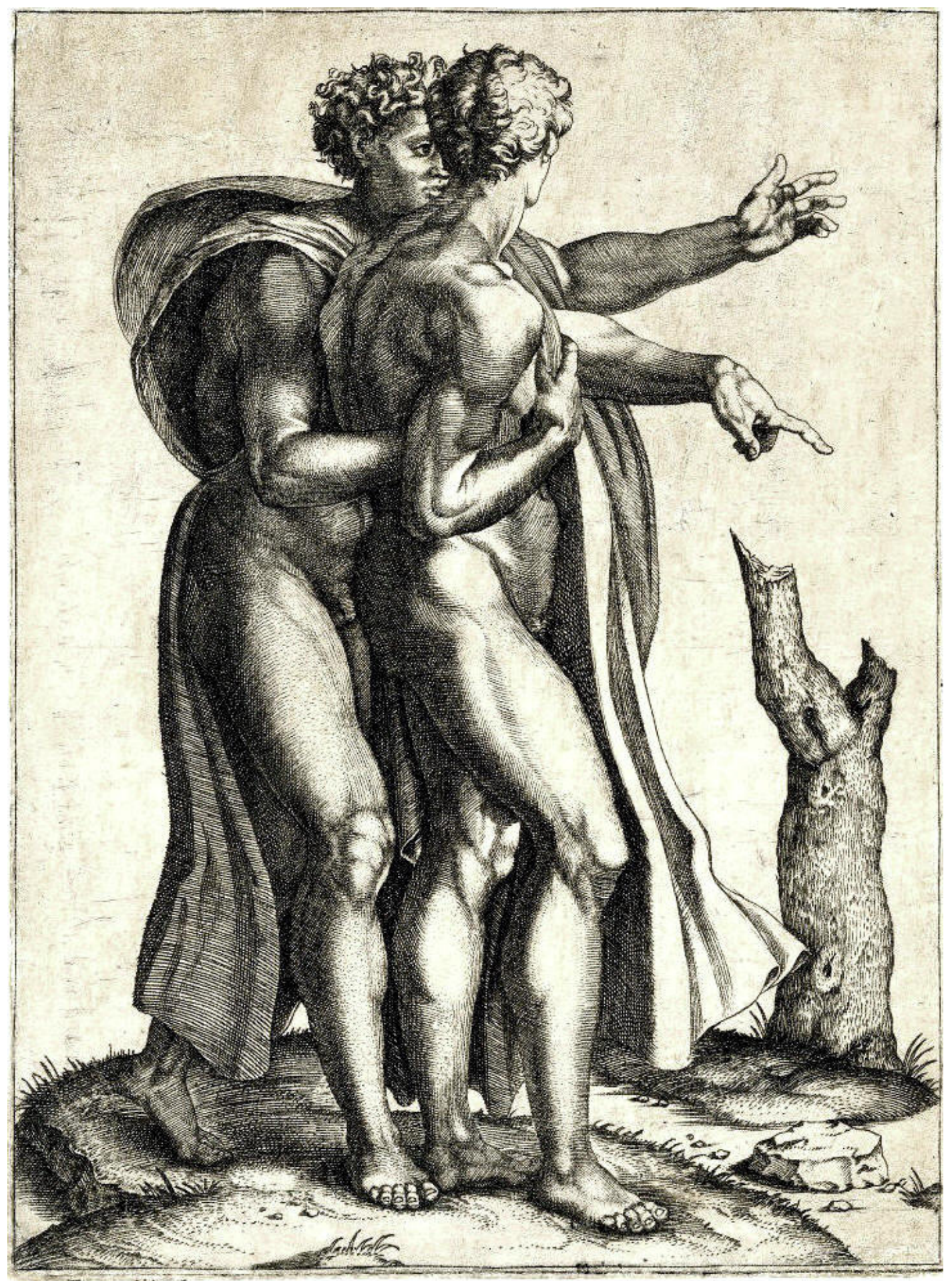

- Marcantonio Raimondi. Dos hombres enlazados. Buril. 1515-20. 
Esta obra poco difundida, quizás por lo ambiguo del tema y el desconocido dibujo en el que se basa, posee las mismas características que la "Expulsión del Paraíso", con especial interés en las transiciones tonales que modelan las figuras a base de puntos de diversa intensidad. El influjo de la obra de Miguel Ángel está claramente presente. La representación de las dos figuras masculinas con la fuerte influencia escultórica de sus anatomías tiene referencias evidentes en los frescos de la Capilla Sixtina.

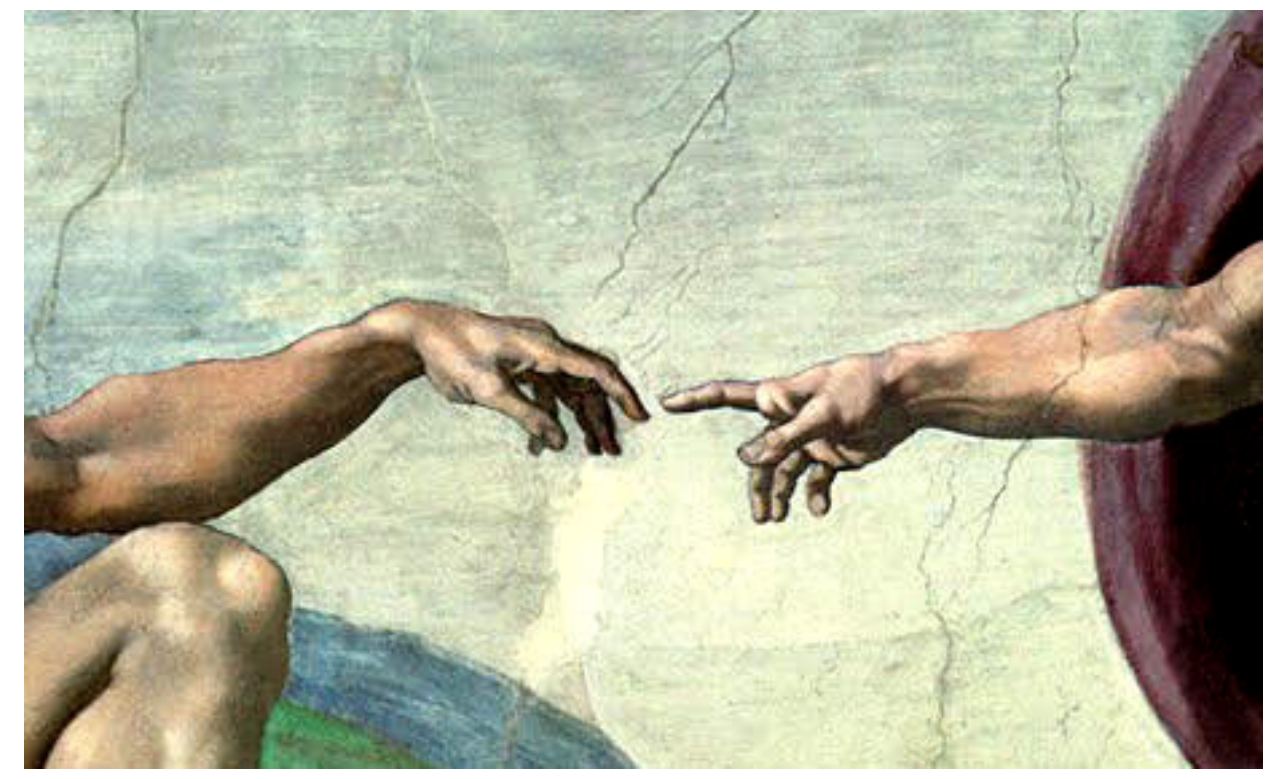

- Miguel Ángel, detalle de "La creación del hombre". 1508-12.

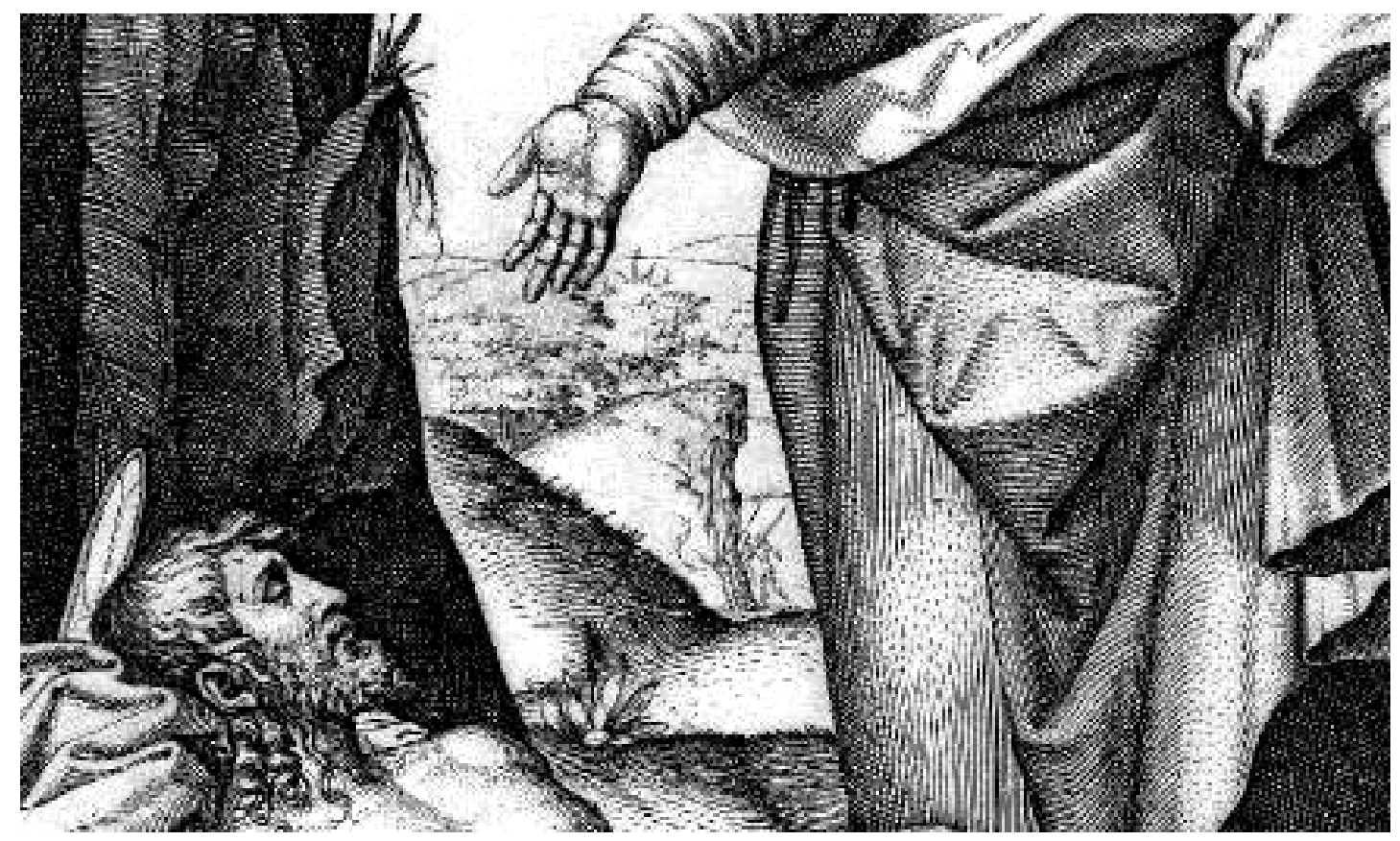

- Detalle de "Lamento de la Virgen". 1515-20. 


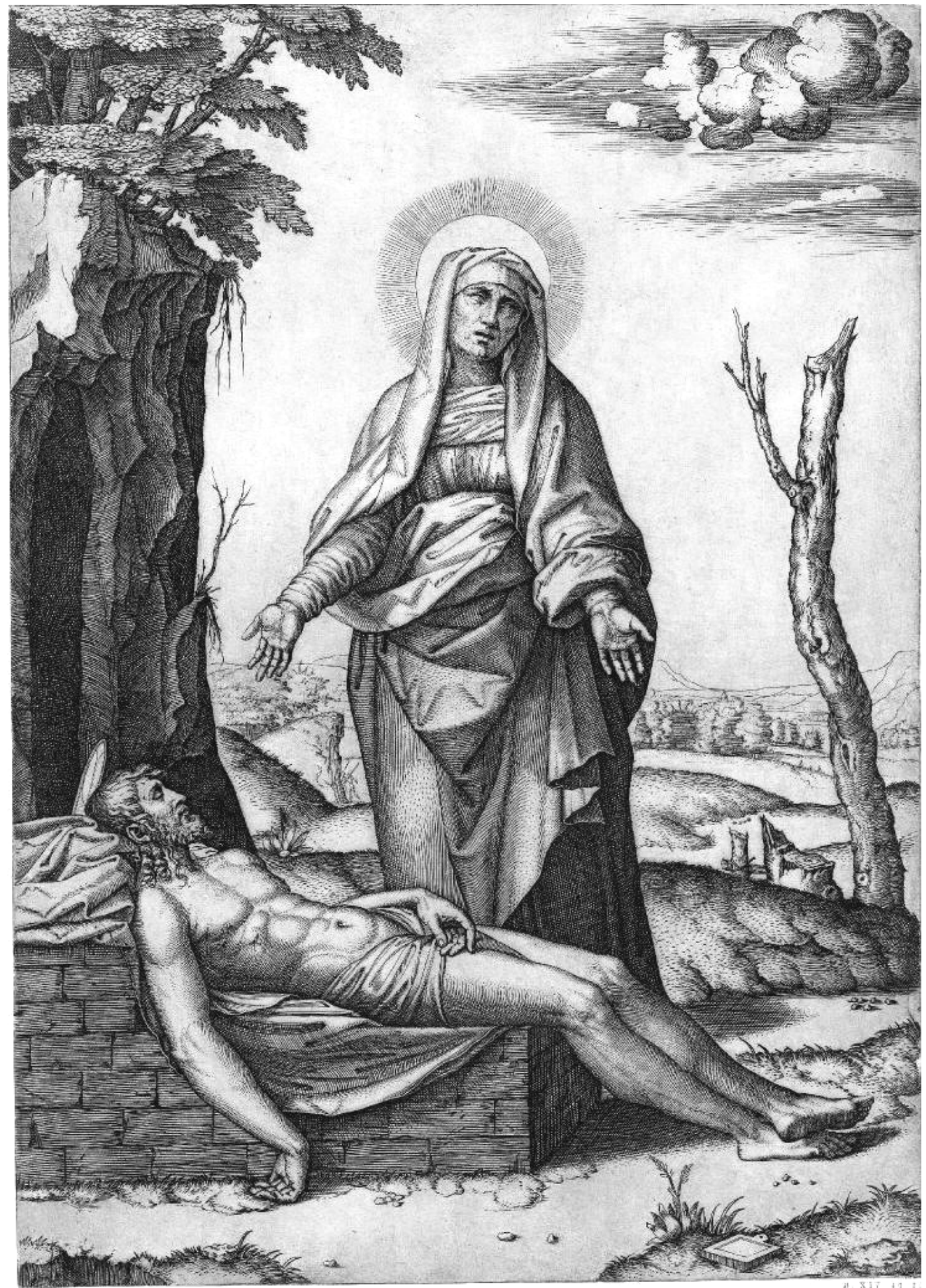

- Marcantonio Raimondi según Rafael. Lamento de la Virgen. Buril. 1515-20.

En el Lamento de la Virgen, su estilo y técnica consiguen uno de los resultados más armoniosos de este periodo. El modelado escultórico de los ropajes, la inclusión del árbol seco y la expresión de la Virgen que dramatizan la imagen, la delicada representación del paisaje y el dominio del buril con sus eficaces normas, contribuyen decisivamente a ello. Curiosamente, la desproporción entre las figuras de María y 
Cristo no resulta evidente a primera vista, el objetivo debió ser el de potenciar el drama expresado por la figura doliente de la Virgen y el resultado responde a las expectativas.

El proyecto más ambicioso y complejo basado en un original de Rafael puede que sea "El Juicio de Paris". El éxito y la influencia de esta estampa queda demostrado gracias al gran número de versiones grabadas posteriormente, en su taller y fuera de él, o al reflejo de la obra o de elementos de ella presentes en obras pertenecientes a otras disciplinas. La imagen de la antigüedad clásica es trasmitida por Rafael y Raimondi y reflejada en la producción artística posterior.

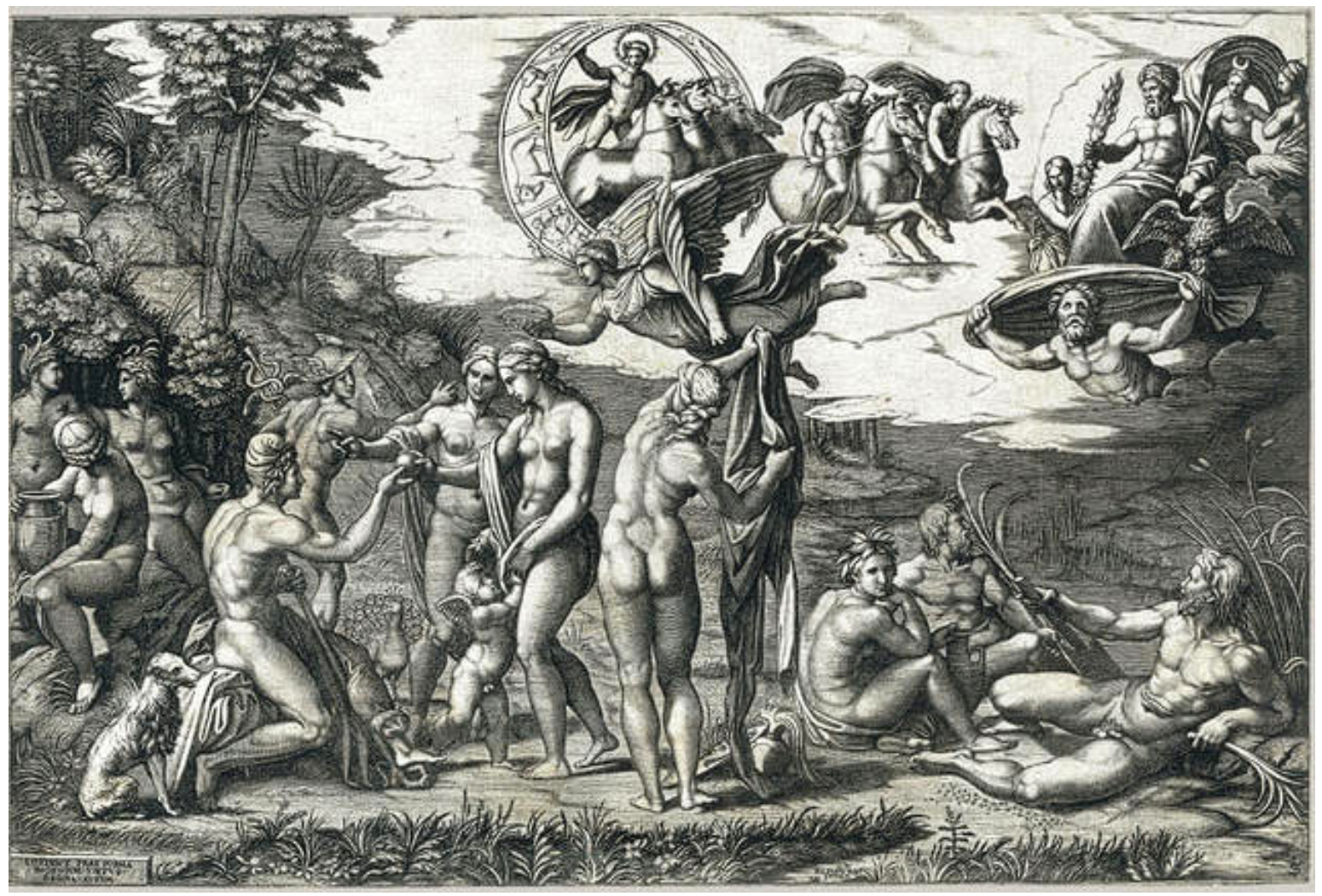

-Marcantonio Raimondi según Rafael. El Juicio de Paris. Buril. 1517-20.

De nuevo la composición, que gira en torno al eje central marcado por el desnudo femenino de espaldas, se divide en dos zonas de iluminación opuesta y ambas están eficazmente resueltas. Alto contraste en la zona celeste frente al trabajo de transiciones tonales que define el primer plano, donde se desarrolla la escena principal en la que Paris entrega la manzana a la diosa más bella según su elección. Marcantonio erosionó ligeramente la superficie de la plancha antes de grabarla, lo que da al conjunto un tono general que unifica el resultado, claro precedente del aguatinta.

Al equilibrio compositivo y la variedad tonal conseguida gracias a la técnica desarrollada por Marcantonio, se añaden el impacto iconográfico que esta imagen generó. Transmite todo aquello que la época reivindicaba, el humanismo de los cuerpos tomado como arquetipo, el desnudo monumental basado en el conocimiento rescatado de la cultura grecorromana y la observación y análisis de la naturaleza. 
Rafael, del que se conoce la autoría de la composición, recurrió a las fuentes antiguas, sarcófagos romanos y obras como el Laooconte o el torso Belvedere, a su propia interpretación de estos testimonios y a la influencia del trabajo que Miguel Ángel ejerció sobre el mundo artístico de Roma en este momento histórico. La madurez técnica de Marcantonio Raimondi y la comunión de intereses existente, consiguieron uno de los resultados más adecuados a los objetivos que entre artista y grabador se puedan obtener.

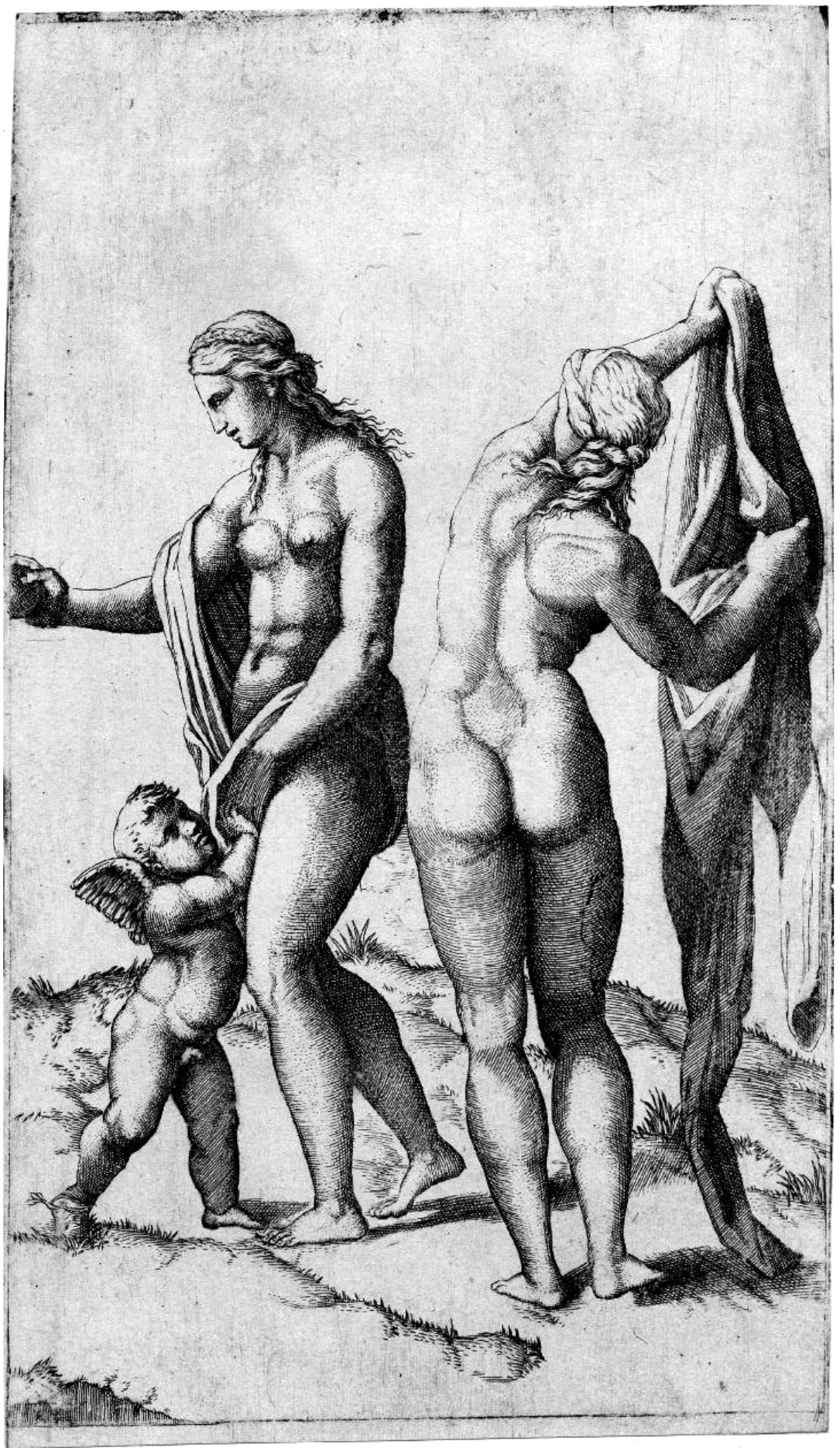

- Marcantonio Raimondi. Venus, Cupido y Atenea. 1517-20 


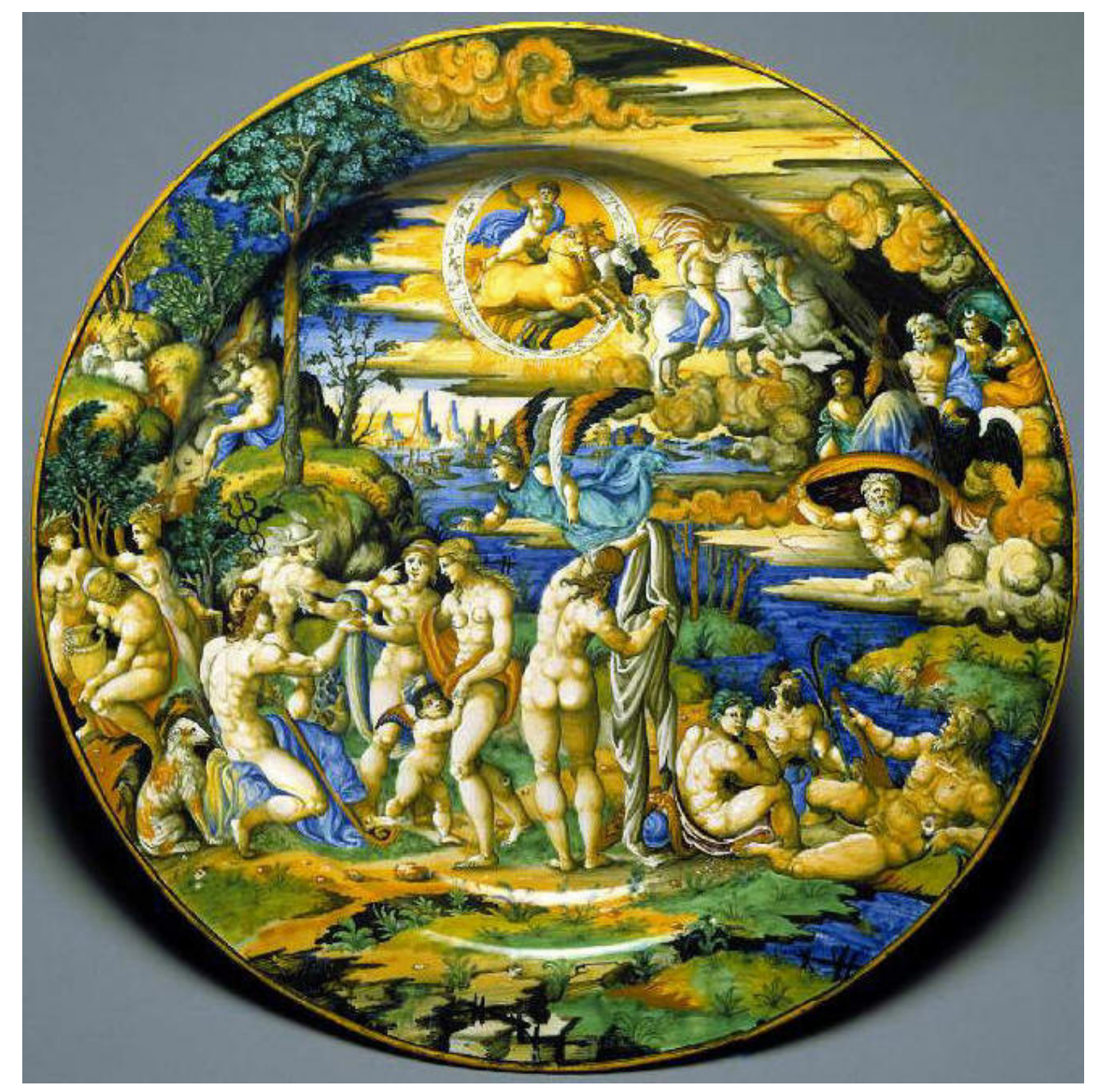

- Guido Durantino. Taller de Urbino. 1517-1550.

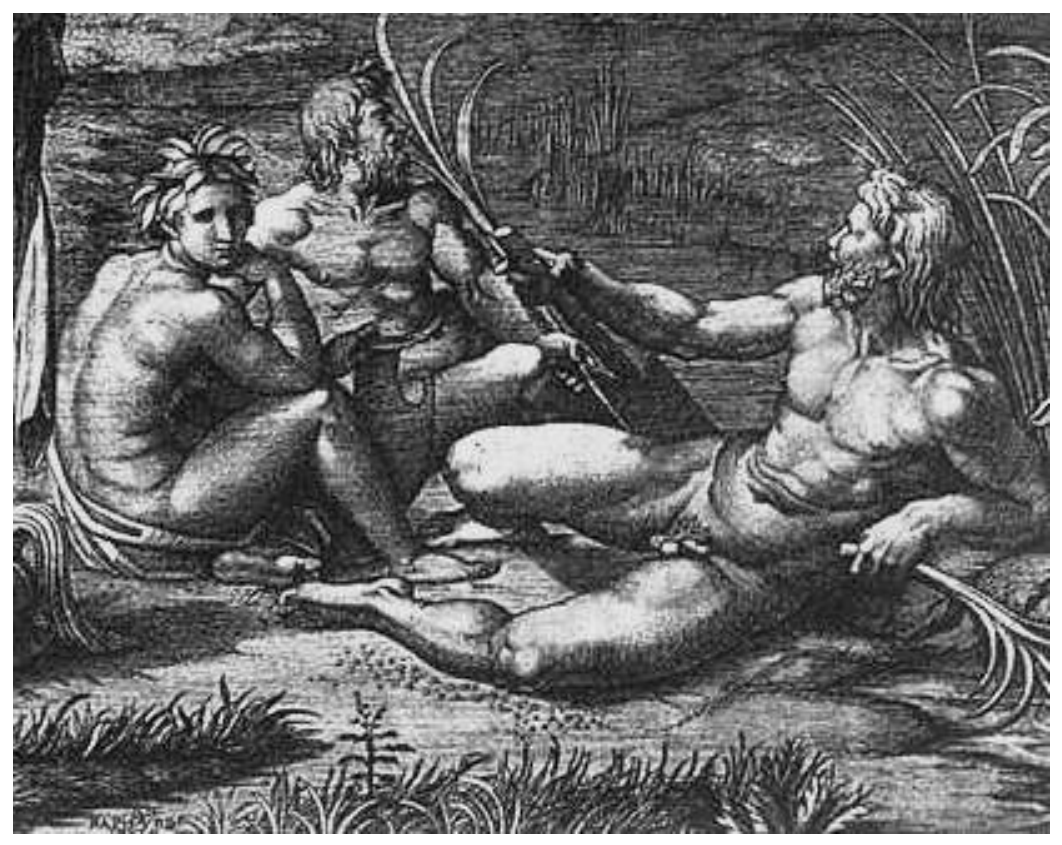

- Marcantonio Raimondi. El Juicio de Paris, detalle. 1517-20. 


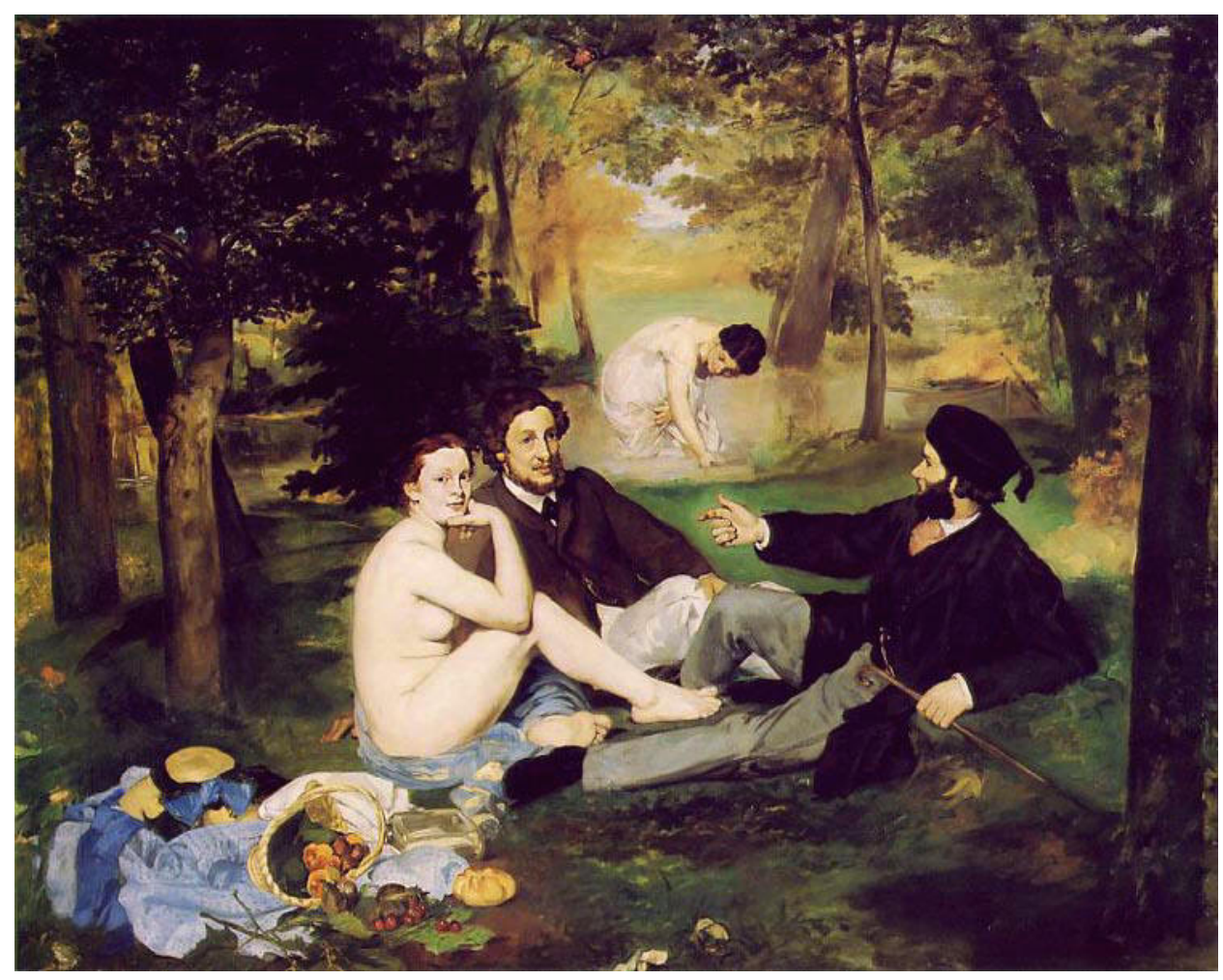

-Edouard Manet según Marcantonio Raimondi según Rafael. Le déjeuner sur l'herbe. Óleo sobre lienzo.1863.

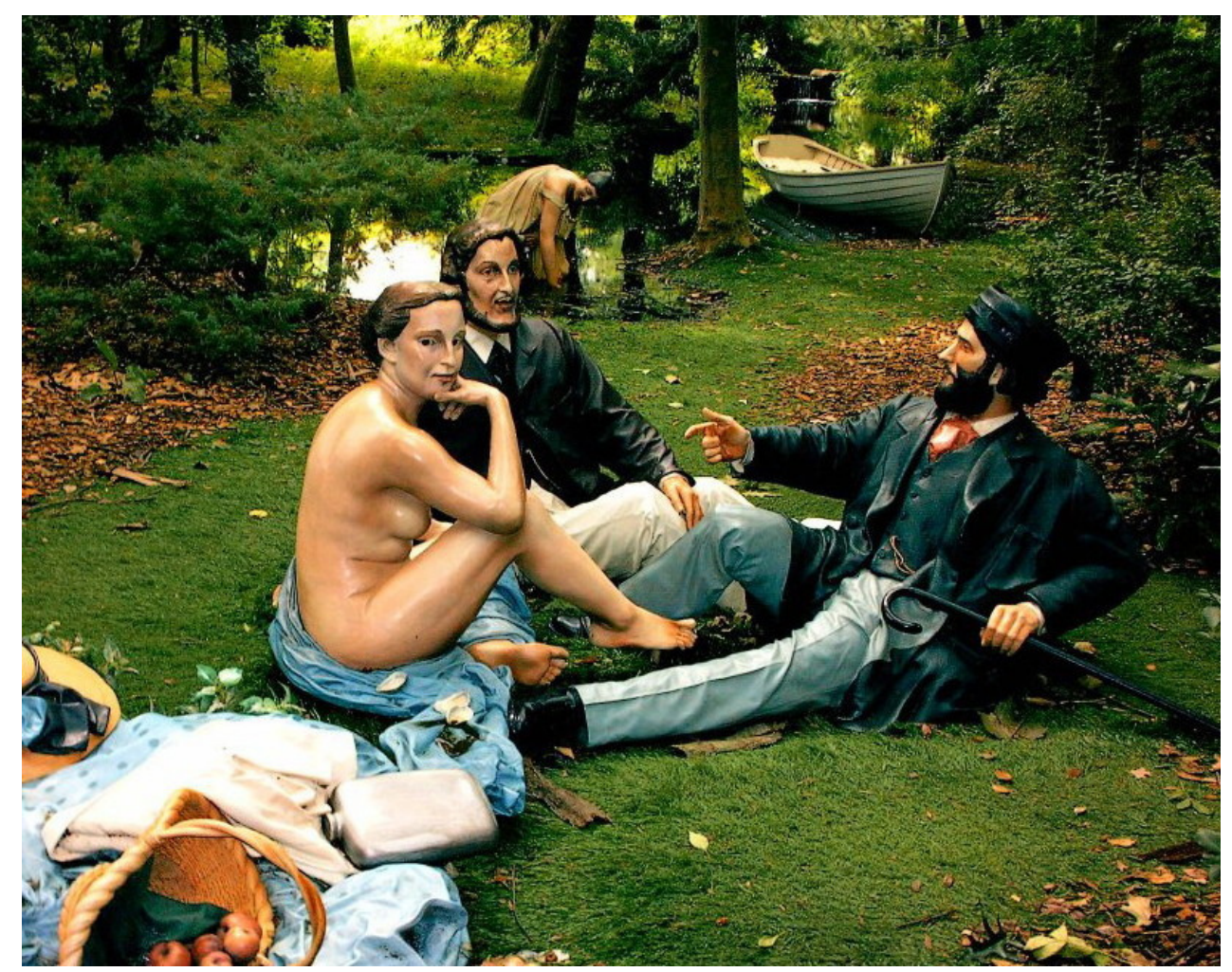

- John Seward Jonson, según Manet según Marcantonio según Rafael. Le déjeneur sur I'herbe. Bronce policromado. 1994. 


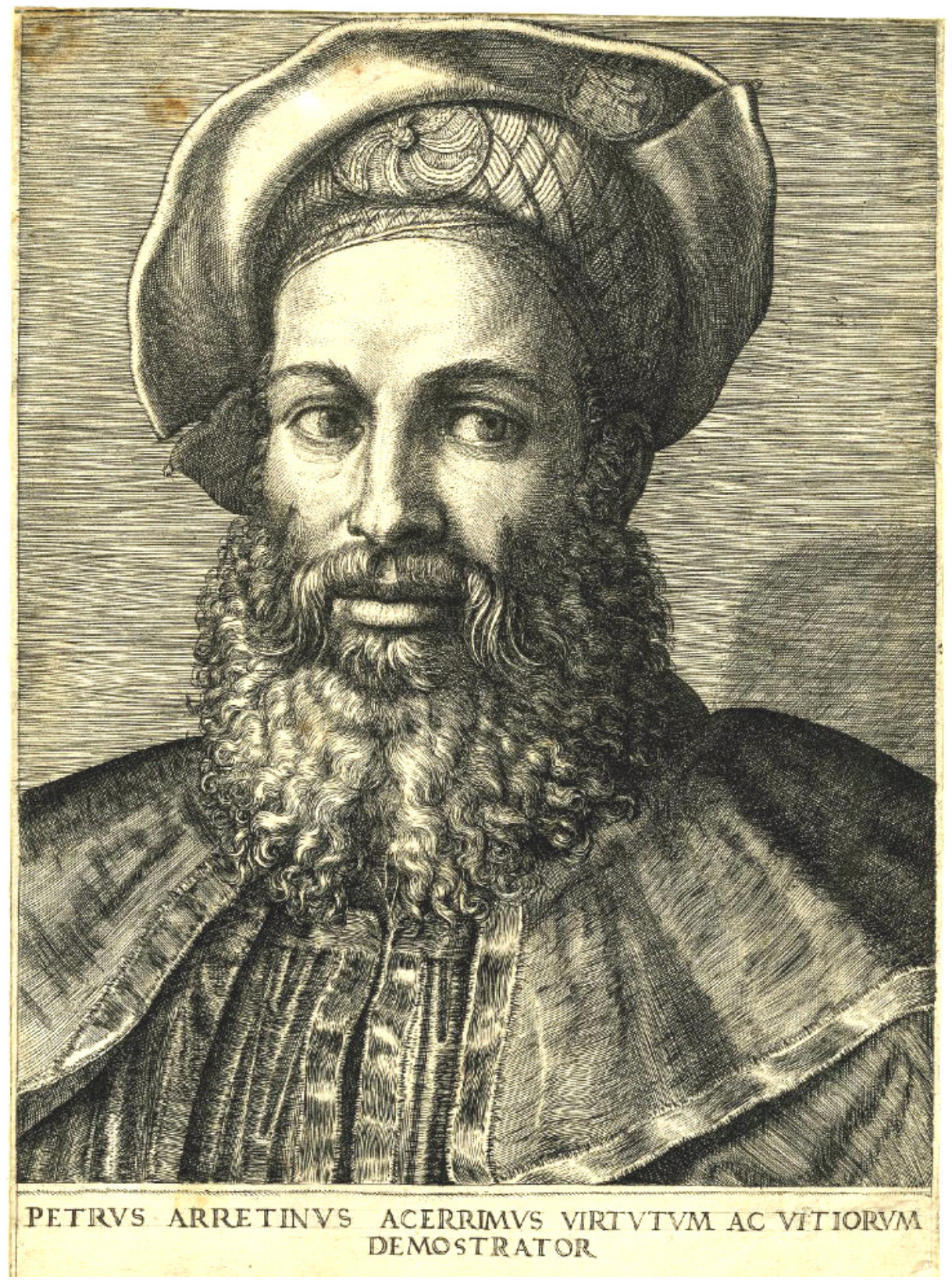

- Marcantonio Raimondi. Retrato de Pietro Aretino. Buril. 1517-20.

Se desconoce de qué mano procede el original de este retrato. Parece probable que Marcantonio trabajara a partir de un dibujo de Julio Romano aunque también se han barajado los nombres de Sebastiano del Piombo y Tiziano como posibles autores. Estilísticamente la obra se relaciona con los trabajos del periodo 1517-20. Luminosidad sutil y variedad textural, gran delicadeza técnica en los efectos de tonos granulados y en las transiciones tonales. Características muy diferentes a las de Marcantonio en torno a 1524, fecha en la que es encarcelado por orden de Clemente VII tras la publicación de "I Modi", serie de grabados eróticos según dibujos de Julio Romano para los que Aretino compuso un número igual de sonetos. La excarcelación de Raimondi se debió a la intercesión de Aretino ante las autoridades romanas y se baraja la posibilidad de que realizara su retrato como agradecimiento. De ser así, Raimondi recurrió para ello a un estilo practicado tiempo atrás. 


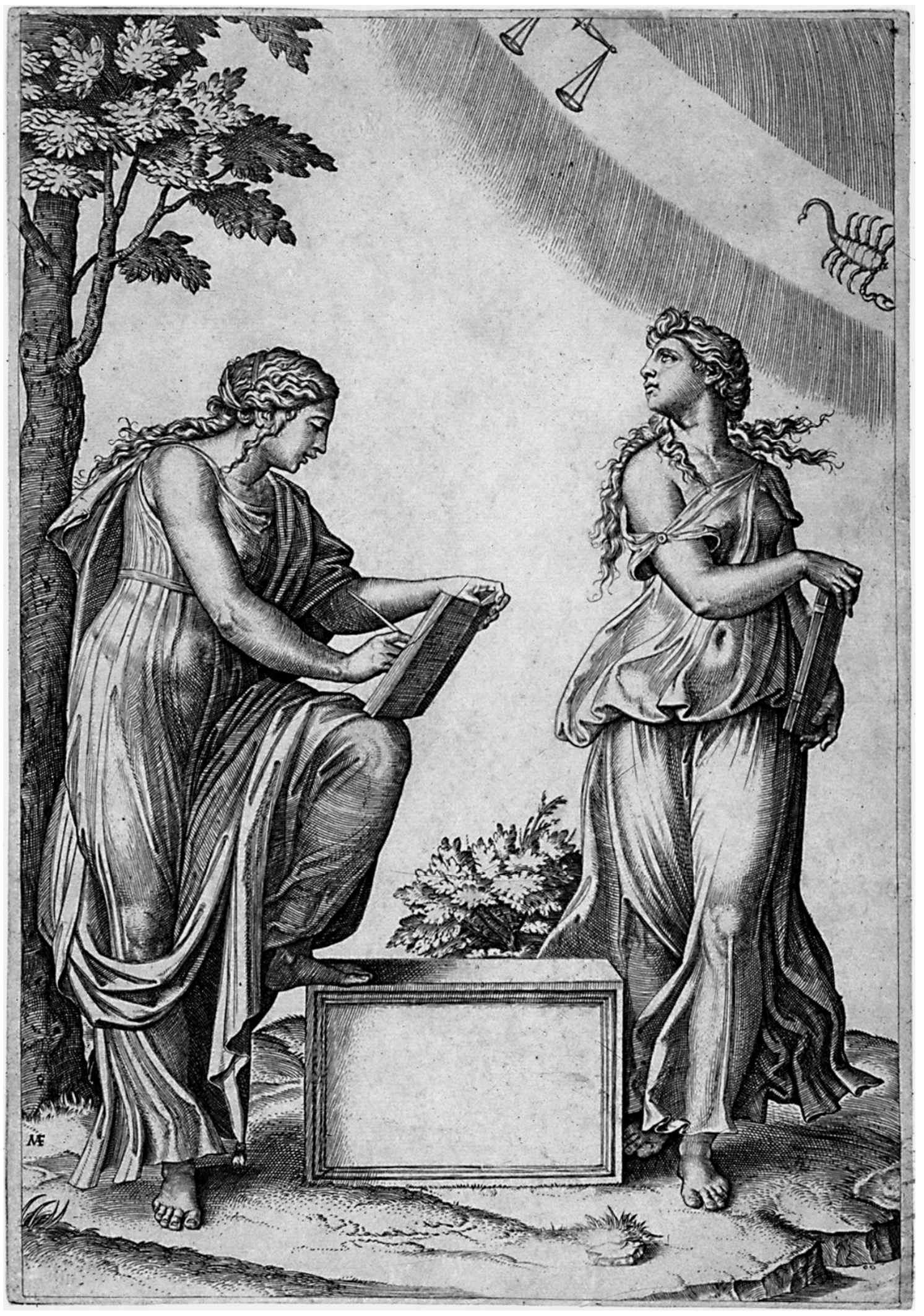

- Marcantonio Raimondi según Rafael. Dos mujeres con los signos de Libra y Acuario. Buril. 1517-20. 


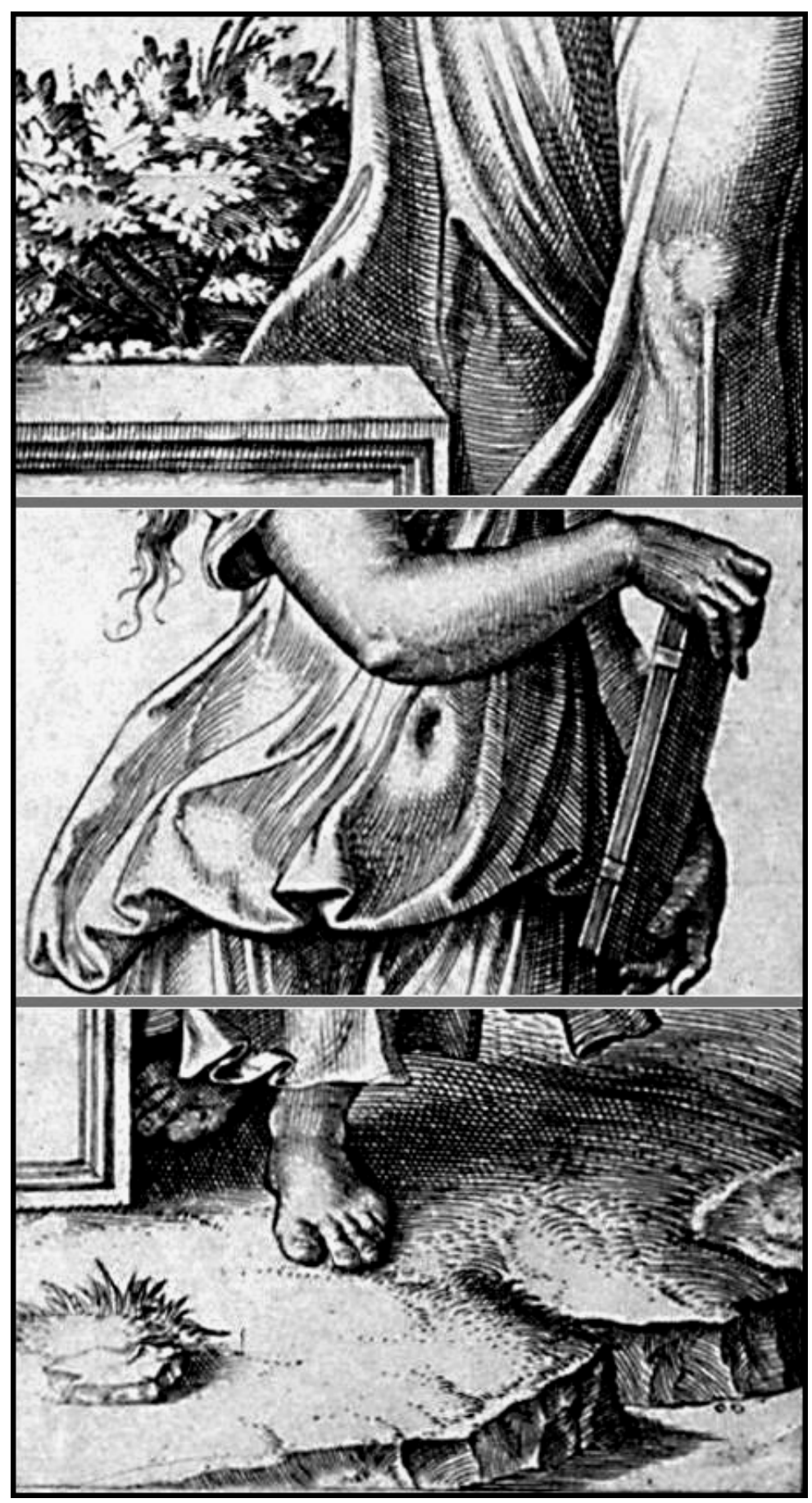

- Tres detalles de la obra "Dos mujeres con los signos de Libra y Acuario".

El uso preciso de la técnica sistematizada de Raimondi en esta imagen, la sitúa entre las realizadas en este periodo final de colaboración con Rafael, que muere en 1520. La tipología femenina ya aparece en la "Galatea" y su interpretación parece estar ligada a la personificación de los signos zodiacales que aparecen en la estampa. Libra, el juicio equilibrado y la razón. Escorpio, pasión y violencia. La mujer de la izquierda ha sido identificada con la Victoria tomando nota de sus triunfos o con Clío, la musa de la Historia. La de la derecha, cuya iconografía está presente en relieves báquicos, como Urania, musa de la astronomía. 
En el Renacimiento, la conjunción de Escorpio y Libra era interpretada como nefasta, anunciaba muerte y cambios religiosos. Está obra se produce en esos tiempos, los de las muertes de Rafael y Julio II y el Cónclave que elevaría al papado a Clemente VII.

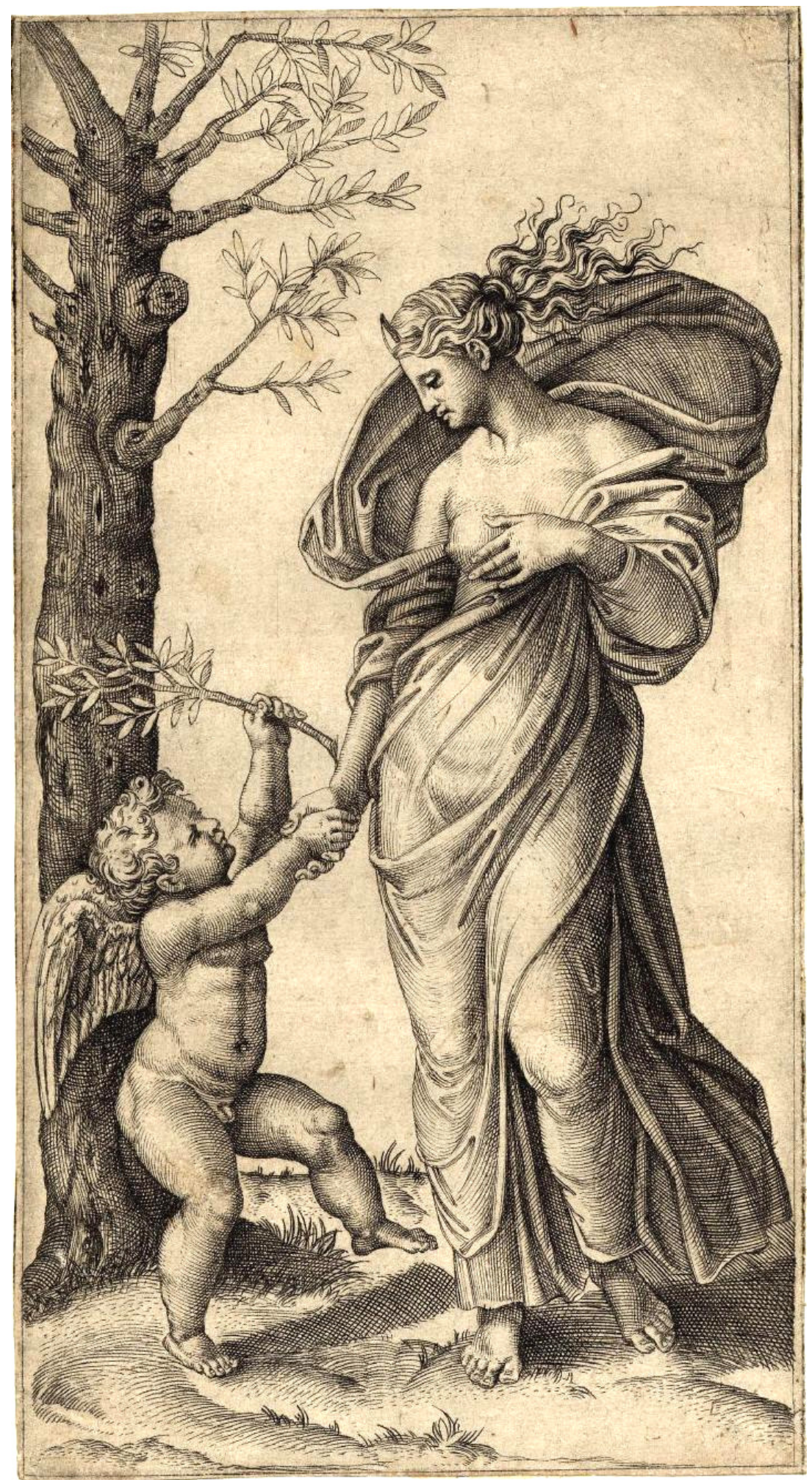

- Marcantonio Raimondi según Rafael. Reconciliación de Minerva y Cupido. Buril. 1517-20. 
En el último periodo estilístico de Marcantonio Raimondi en Roma, comprendido entre 1520 , fecha de la muerte de Rafael y 1527, año del asalto y saqueo de la ciudad por las tropas del emperador Carlos V, trabajará siguiendo originales de Rafael terminados por miembros de su escuela como Francesco Penni o Perino del Vaga y obras de otros autores como Julio Romano o Baccio Bandinelli.

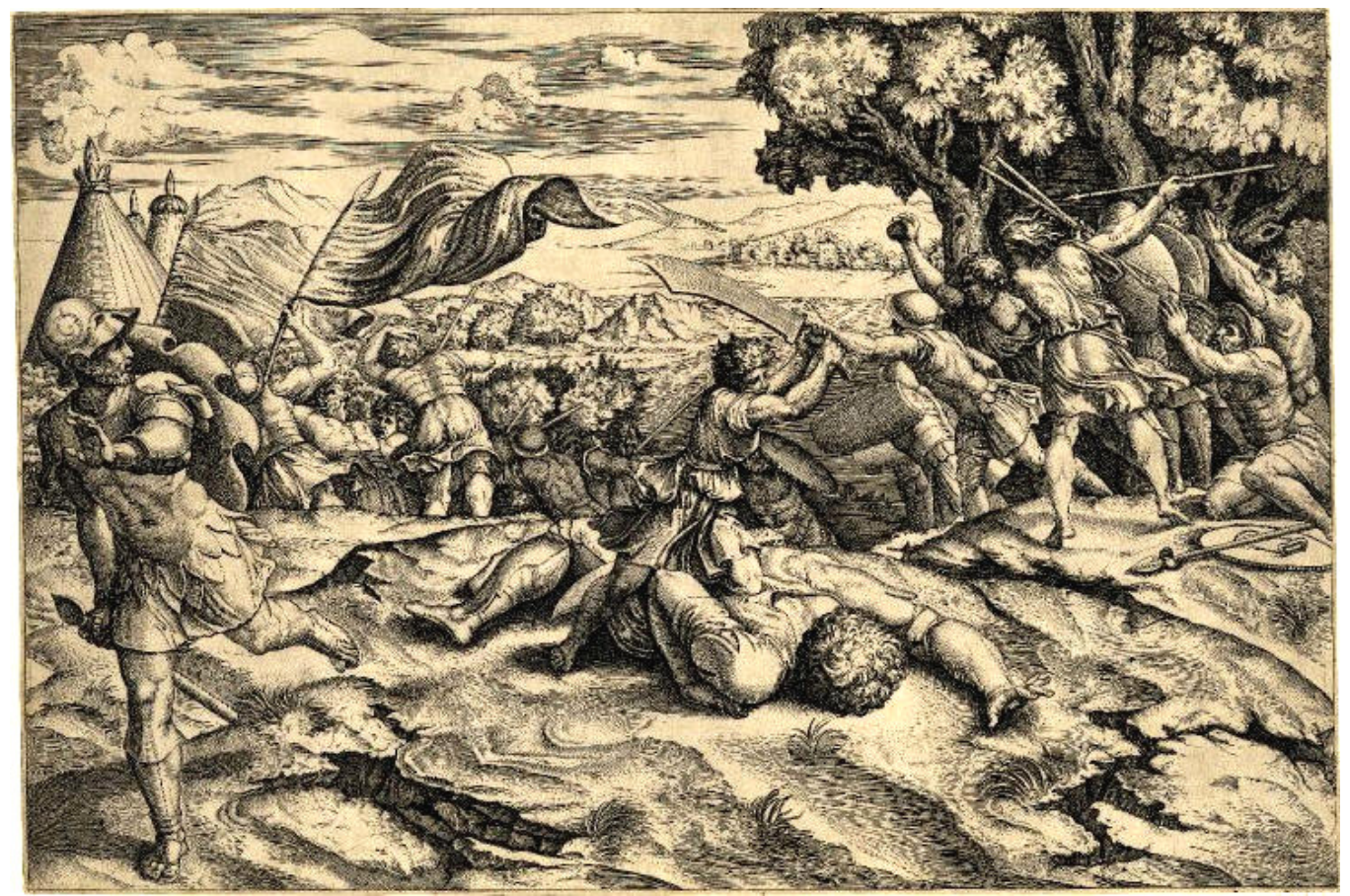

- Marcantonio Raimondi, según Perino del Vaga. David y Goliat. Buril. 1520-25

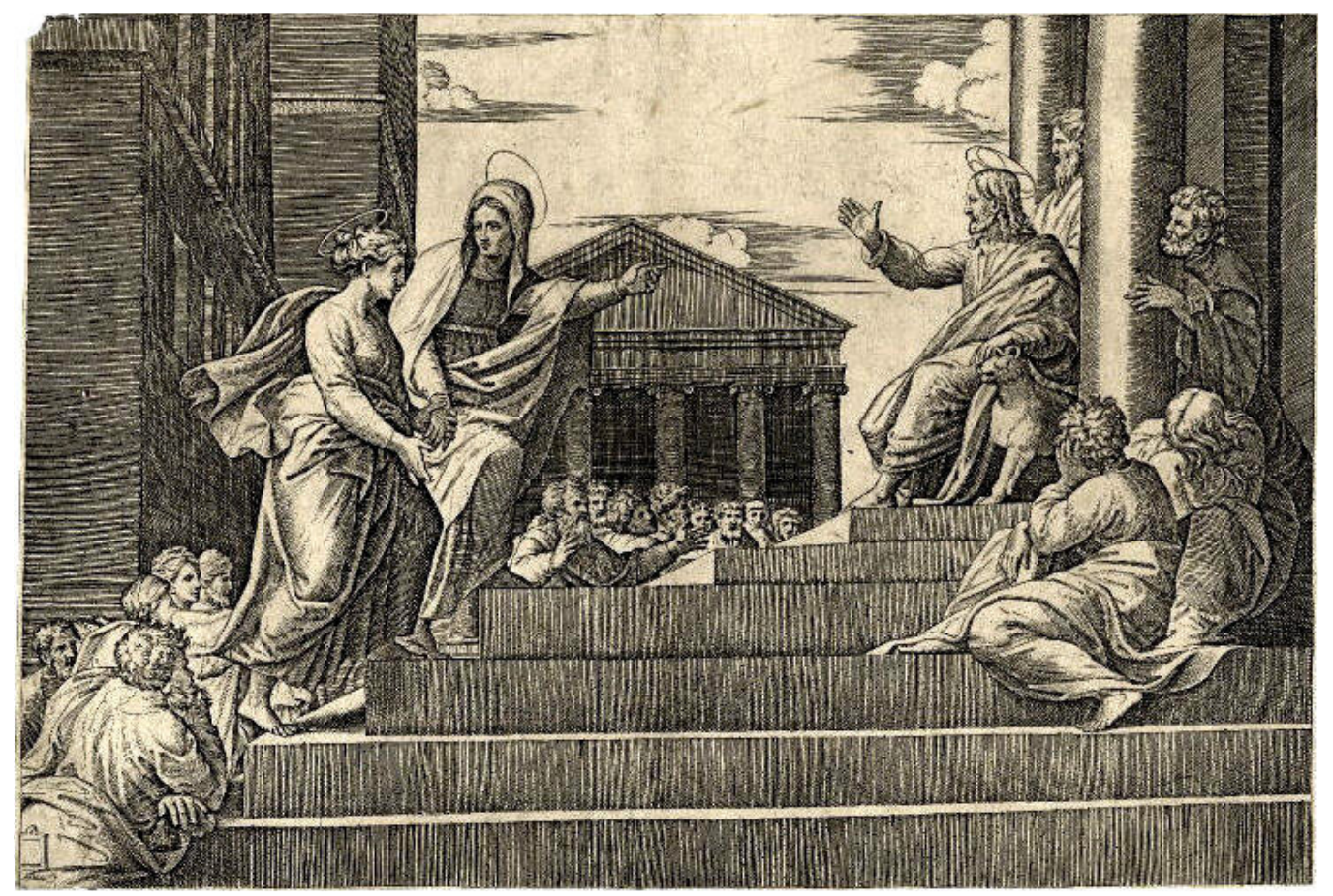

-Marcantonio Raimondi según Julio Romano. Marta conduciendo ante Cristo a María Magdalena. Buril. 1520-25. 
Se ha acusado al Marcantonio de este periodo de desarrollar un estilo seco, mecánico, propio del autor que repite fríamente las fórmulas de su éxito. Aunque la observación del conjunto nos muestra un menor atractivo en buena parte de los resultados, en realidad lo que Raimondi hace es adaptarse a los modelos que recibe e interpreta, y esto lo hace con extremada perfección.
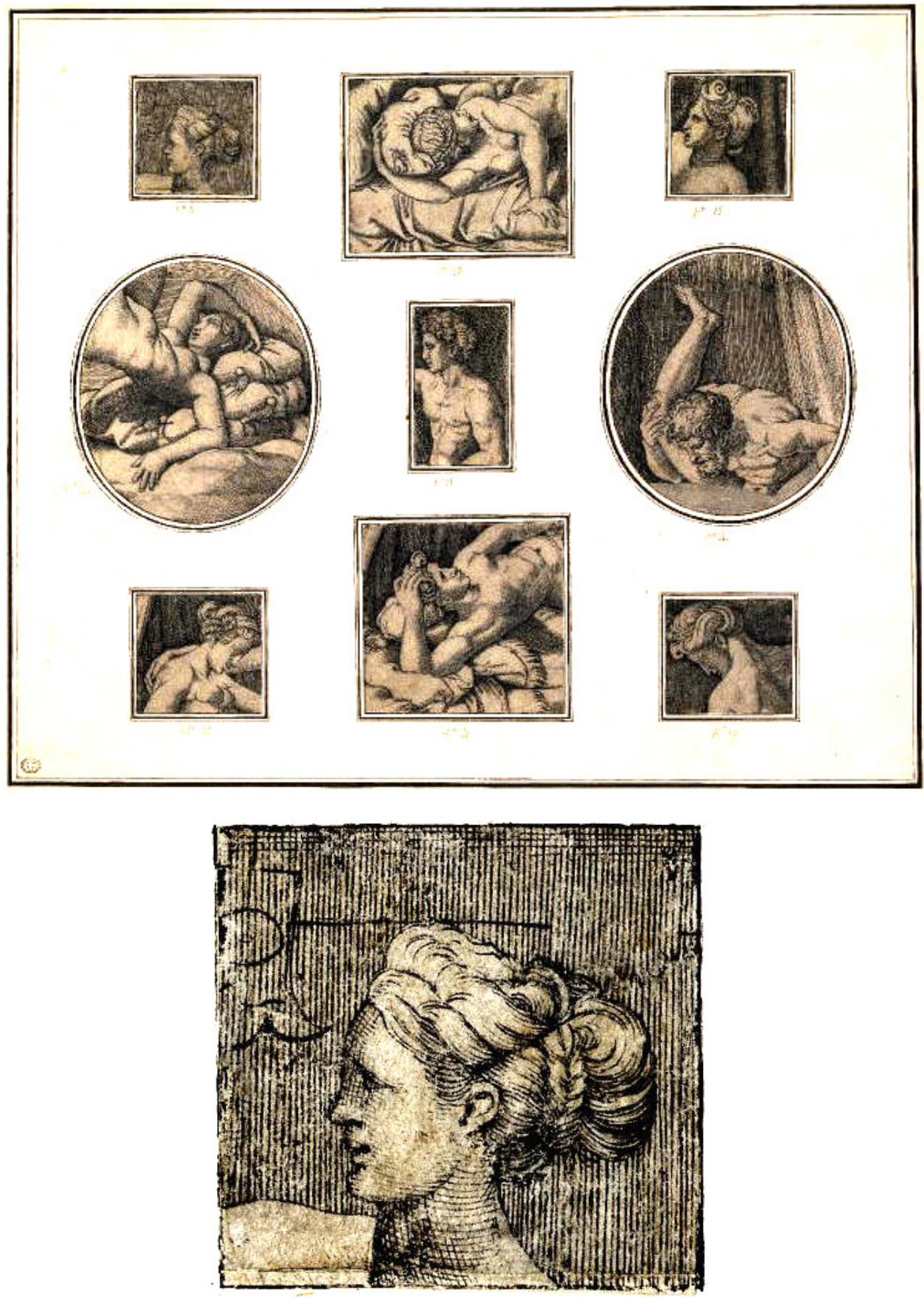

- Marcantonio Raimondi. Fragmentos de I Modi. 1524 
La serie de grabados eróticos según dibujos de Julio Romano, representaba a parejas de personajes mitológicos haciendo el amor en diferentes posturas. Su producción le acarreó la cárcel y la destrucción de todo el material. Unos pocos fragmentos sobrevivieron, aunque hay opiniones que los atribuyen a una reedición de la mano de Agostino Veneziano, si así fuera, nada quedaría de este trabajo de Marcantonio. Los sonetos del Aretino han llegado hasta nuestros días, así como dibujos y grabados inspirados por la obra gráfica de Raimondi.

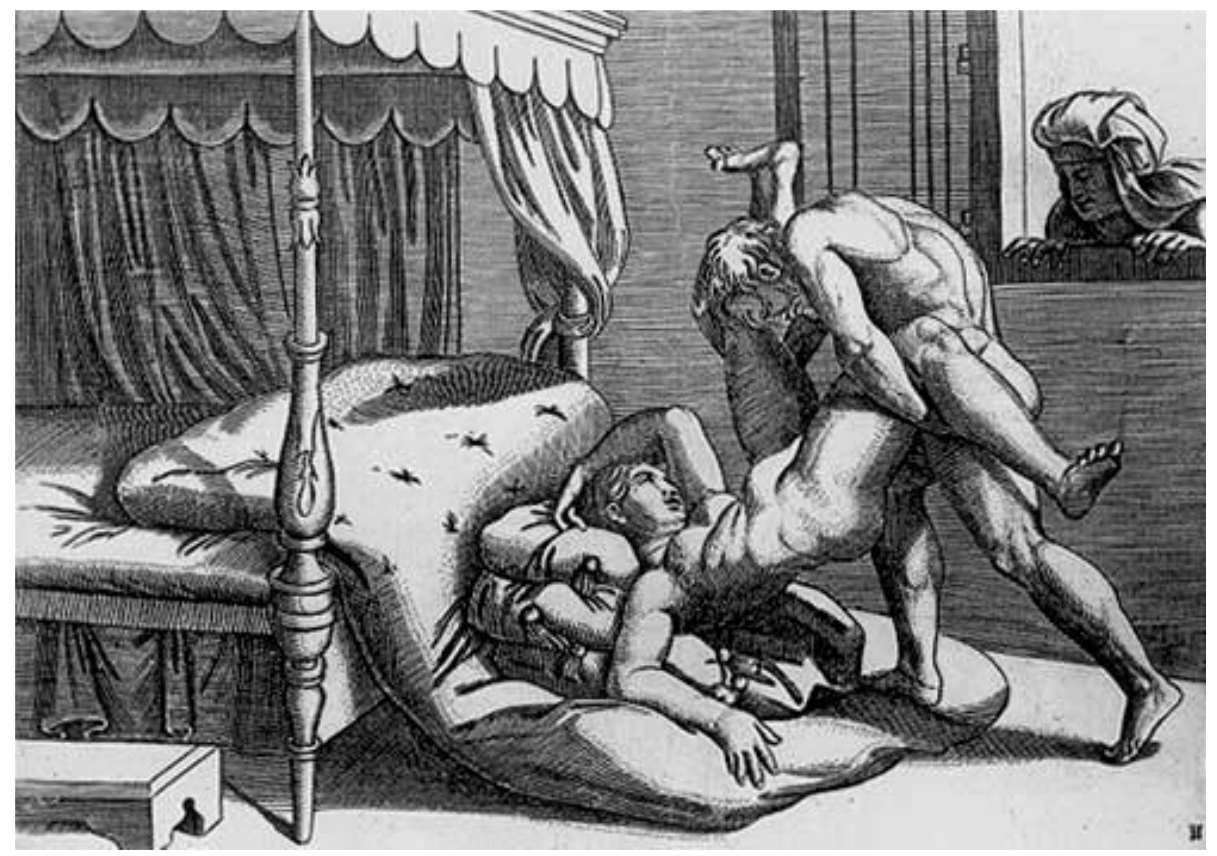

- Escuela de Marcantonio Raimondi según Julio Romano. Placer 16. Buril. Siglo XVI.

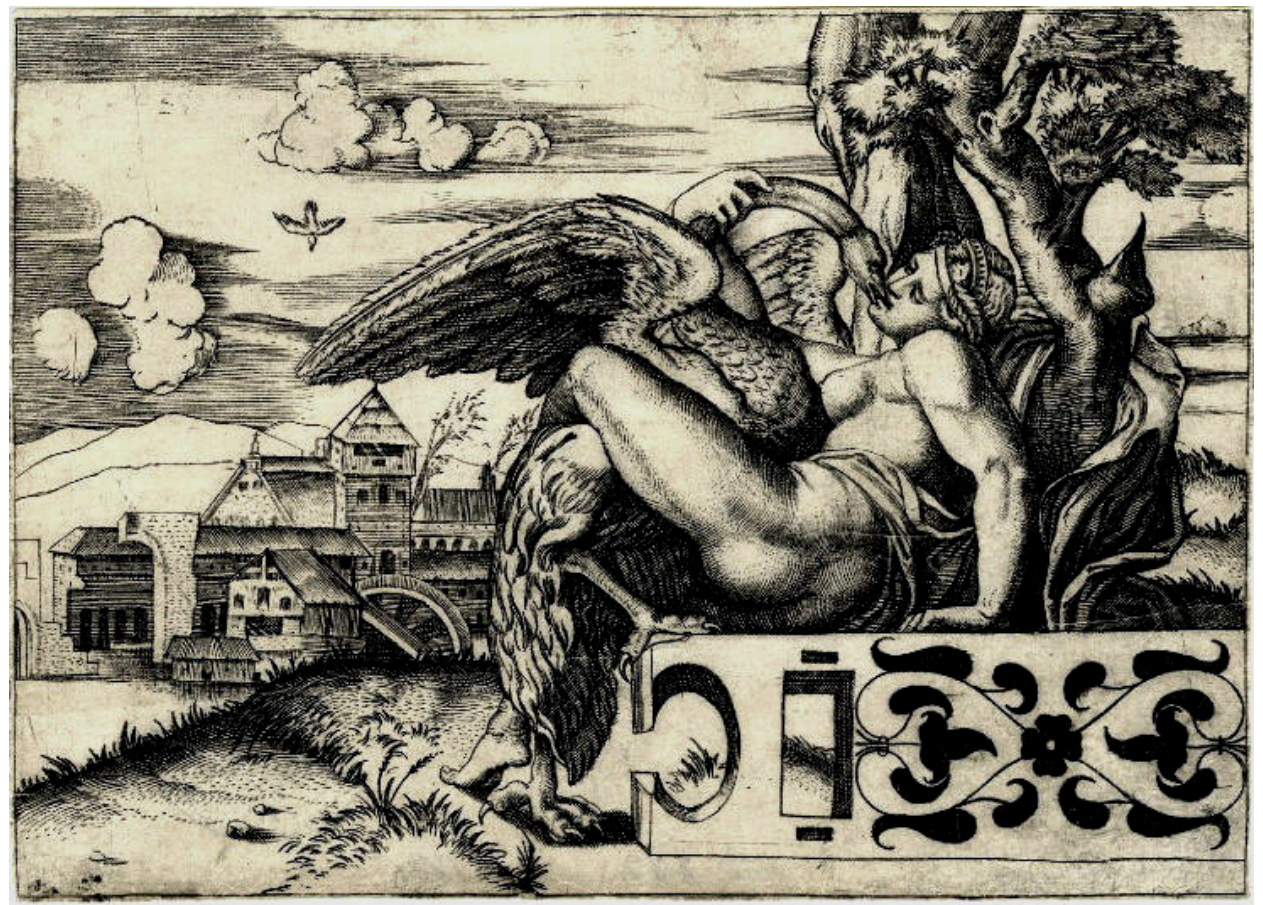

- Agostino Veneziano según Julio Romano. Leda y el Cisne, obra probablemente relacionada con I Modi. Buril. 1510-30. 


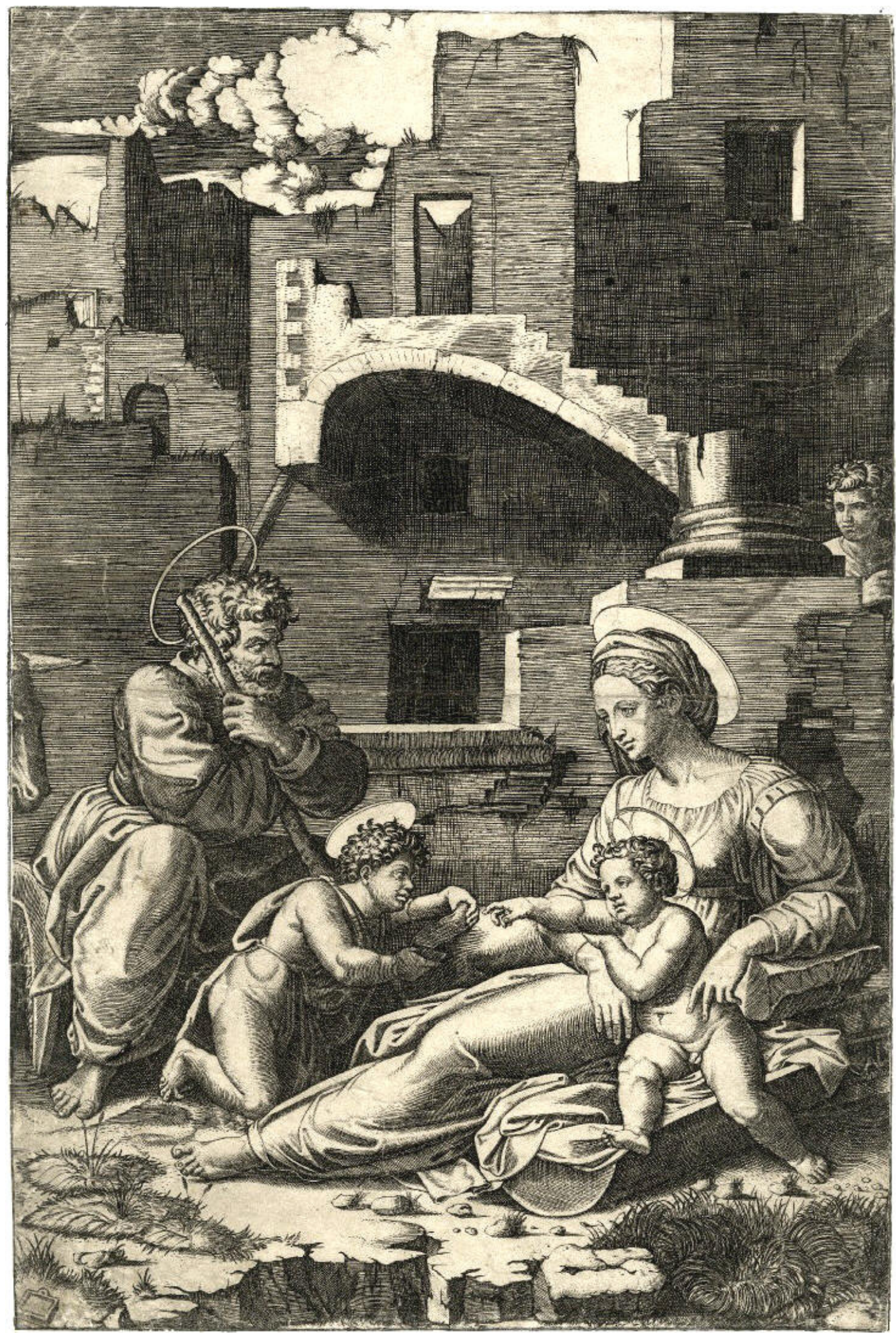

- Marcantonio Raimondi según Julio Romano según Rafael. La Virgen de la pierna larga. Buril. 1520-30. 
En estos años, desmintiendo las críticas negativas sobre la calidad de su obra, produce imágenes como "La Virgen de la pierna larga". Esta obra depende de un dibujo preparatorio de Rafael desarrollado tras su muerte por sus colaboradores, en este caso Julio Romano. La monumentalidad escultórica pertenece tanto a la obra de Julio como al gusto de Marcantonio y el fondo está fuera de lo habitual en sus trabajos. La cercana arquitectura ruinosa tratada a base de densos cruces de líneas y solo rota por destellos de blanco puro, envuelve el conjunto de figuras fuertemente iluminadas y más hieráticas que las inspiradas por Rafael directamente.

Siguiendo un original de Baccio Bandinelli también en este periodo grabará "El Martirio de San Lorenzo", otra de sus obras maestras por perfección técnica y trascendencia artística.

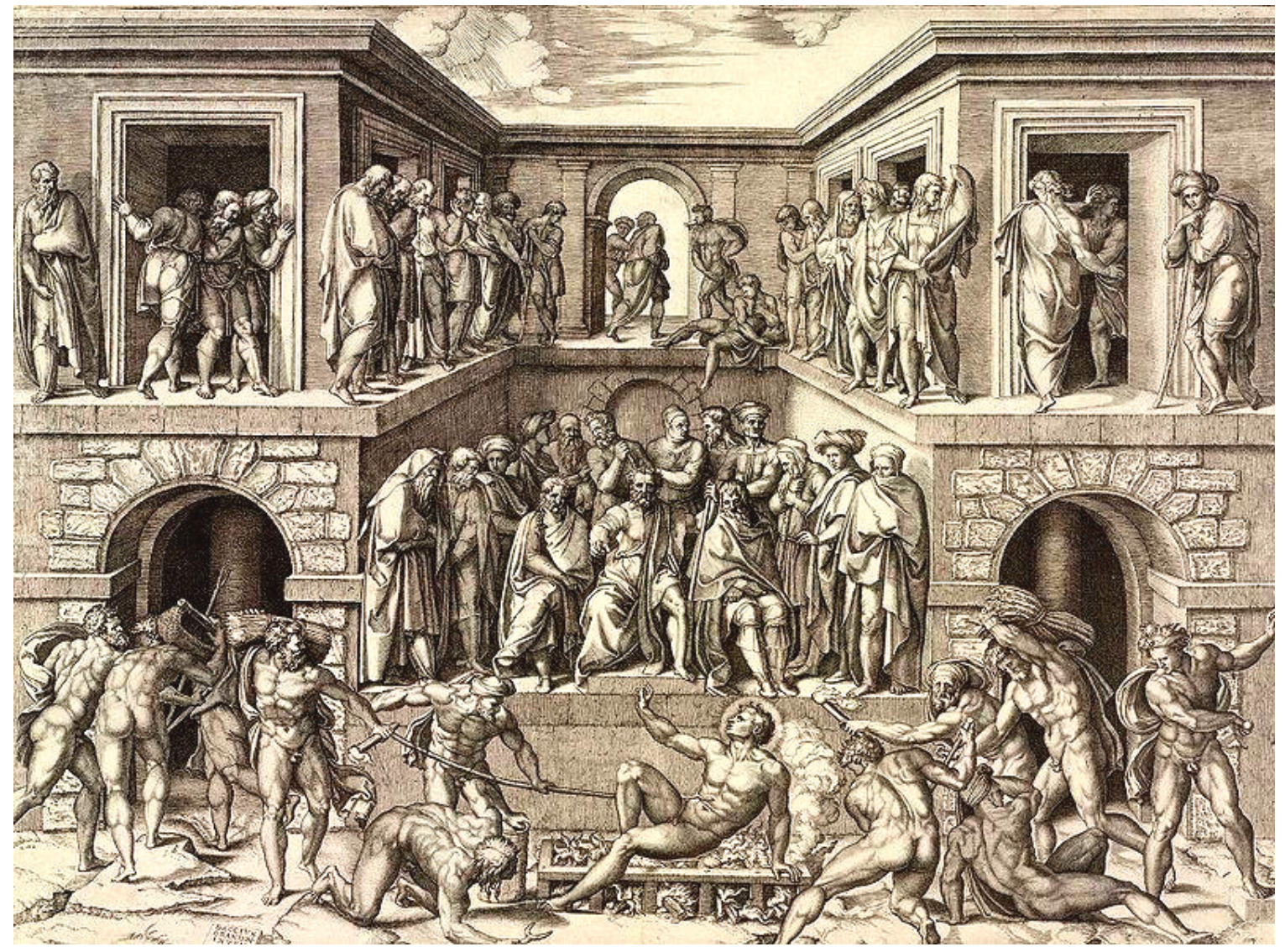

- Marcantonio Raimondi según Baccio Bandinelli. El Martirio de San Lorenzo. Buril. 1520-27.

La estampa, dividida por su eje vertical y con un fuerte punto central de fuga, está dividida en tres niveles en altura y profundidad. En el primer plano, se desarrolla la escena de la ejecución del santo. La figura se encuentra sobre la parrilla flanqueada por dos grupos de verdugos que atizan el fuego y acarrean leña para mantenerlo. De nuevo la estatuaria clásica y las figuras pictóricas y escultóricas de Miguel Ángel son la referencia para construirlos. En el plano medio, el grupo de autoridades que observa la escena, enmarcados por dos arcos y con ropajes cuidadosamente moldeados, parecen asombrados por la situación. No olvidemos que la leyenda nos dice que Lorenzo pidió que le dieran la vuelta en la parrilla porque ya estaba hecho por un lado. 
En el plano arquitectónico superior, el público observa y se mueve entre curioso y extrañado. Nada hay de mecánico en la realización del grabado, Raimondi consigue representar la escena con la máxima eficiencia, siendo capaz al tiempo de entender el espíritu del arte florentino de Bandinelli.
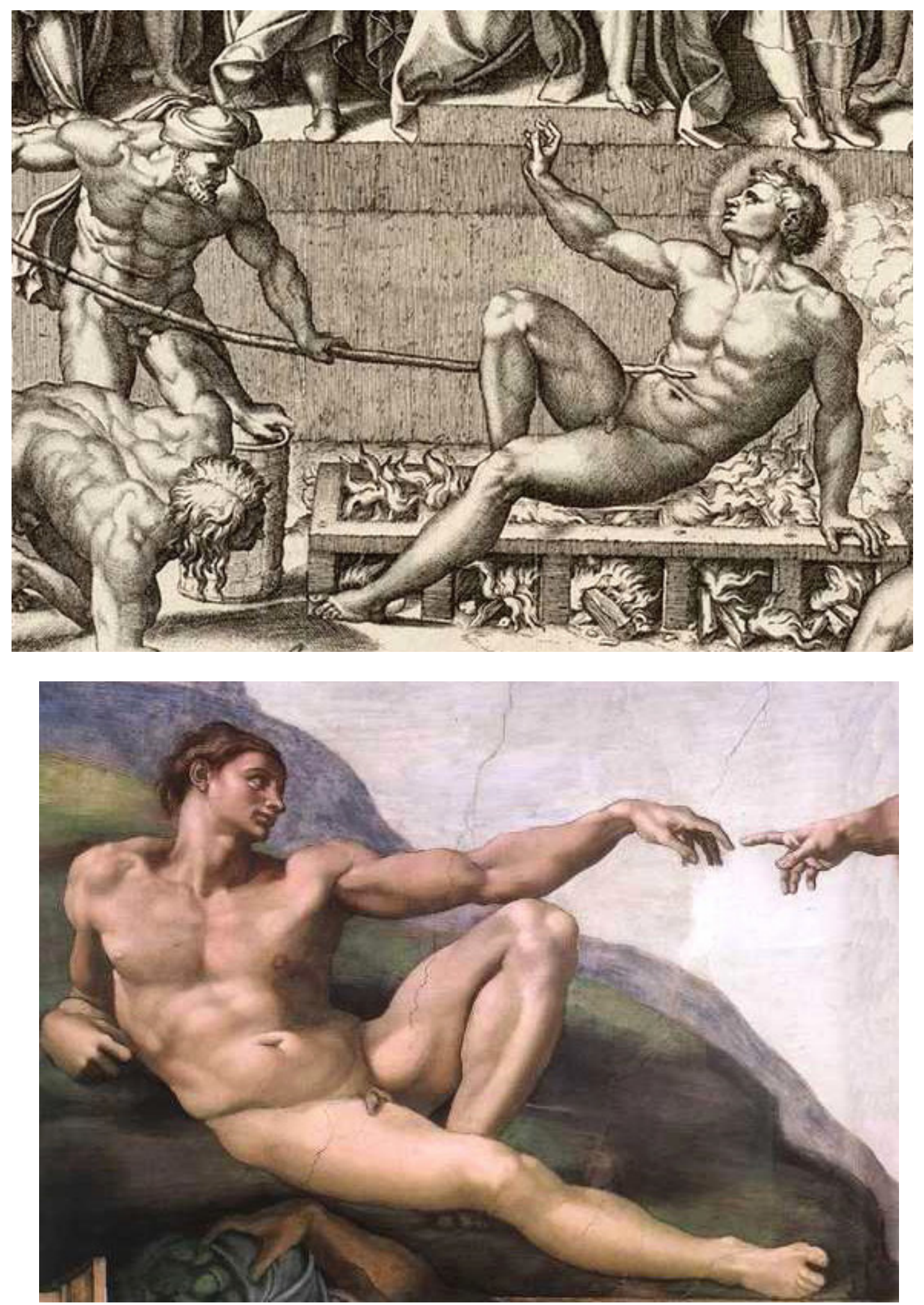

- San Lorenzo, Marcantonio Raimondi y Adán, Miguel Ángel. Detalles. 

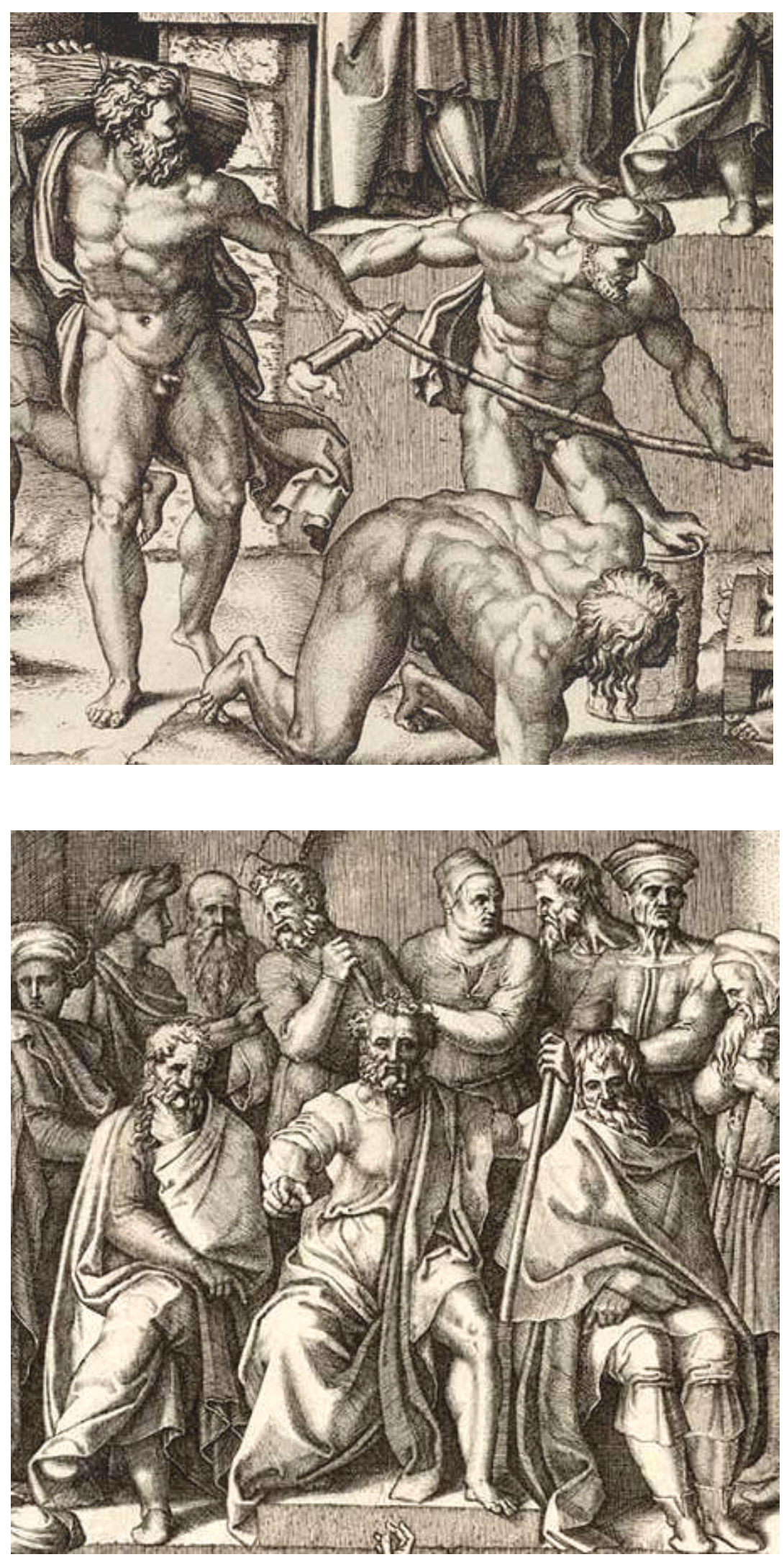

- El Martirio de San Lorenzo. Grupo de verdugos y Grupo de autoridades. Detalles. 

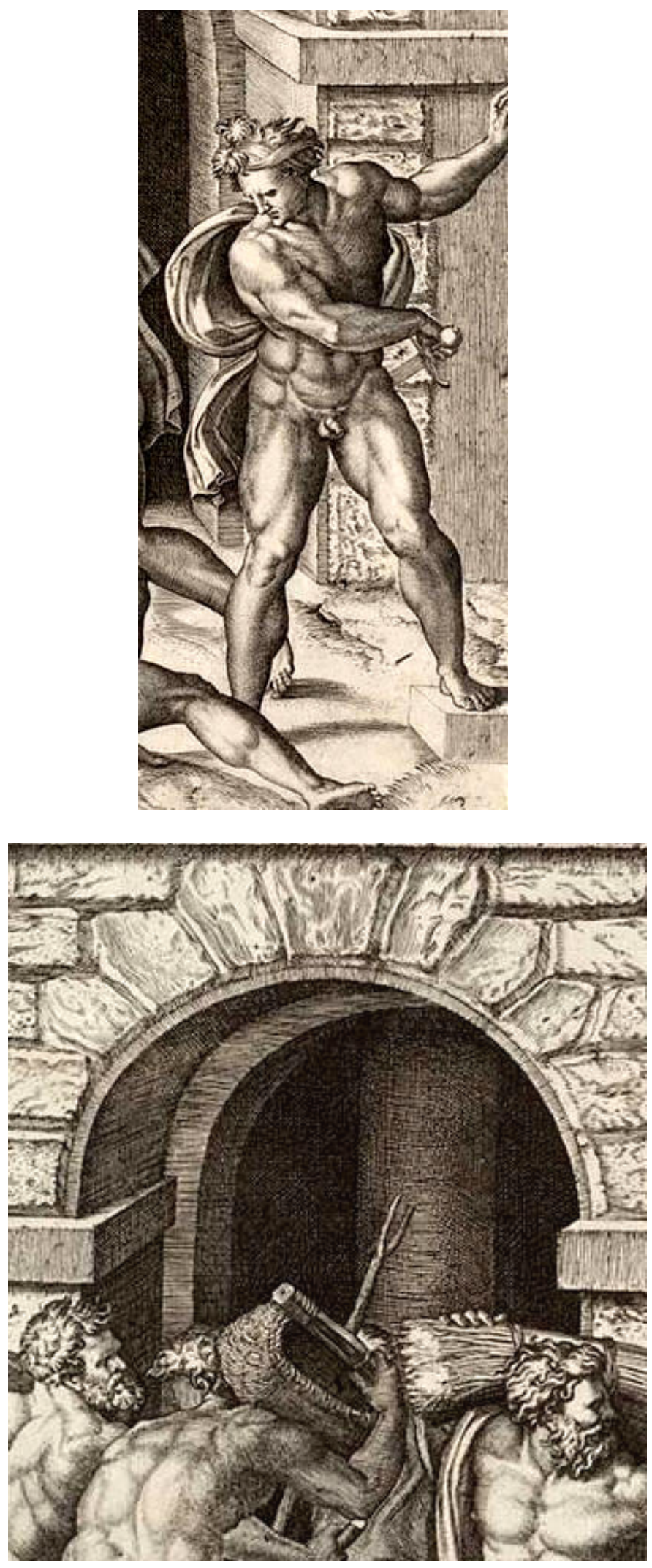

- El Martirio de San Lorenzo. Verdugo y Arco dovelado. Detalles. 

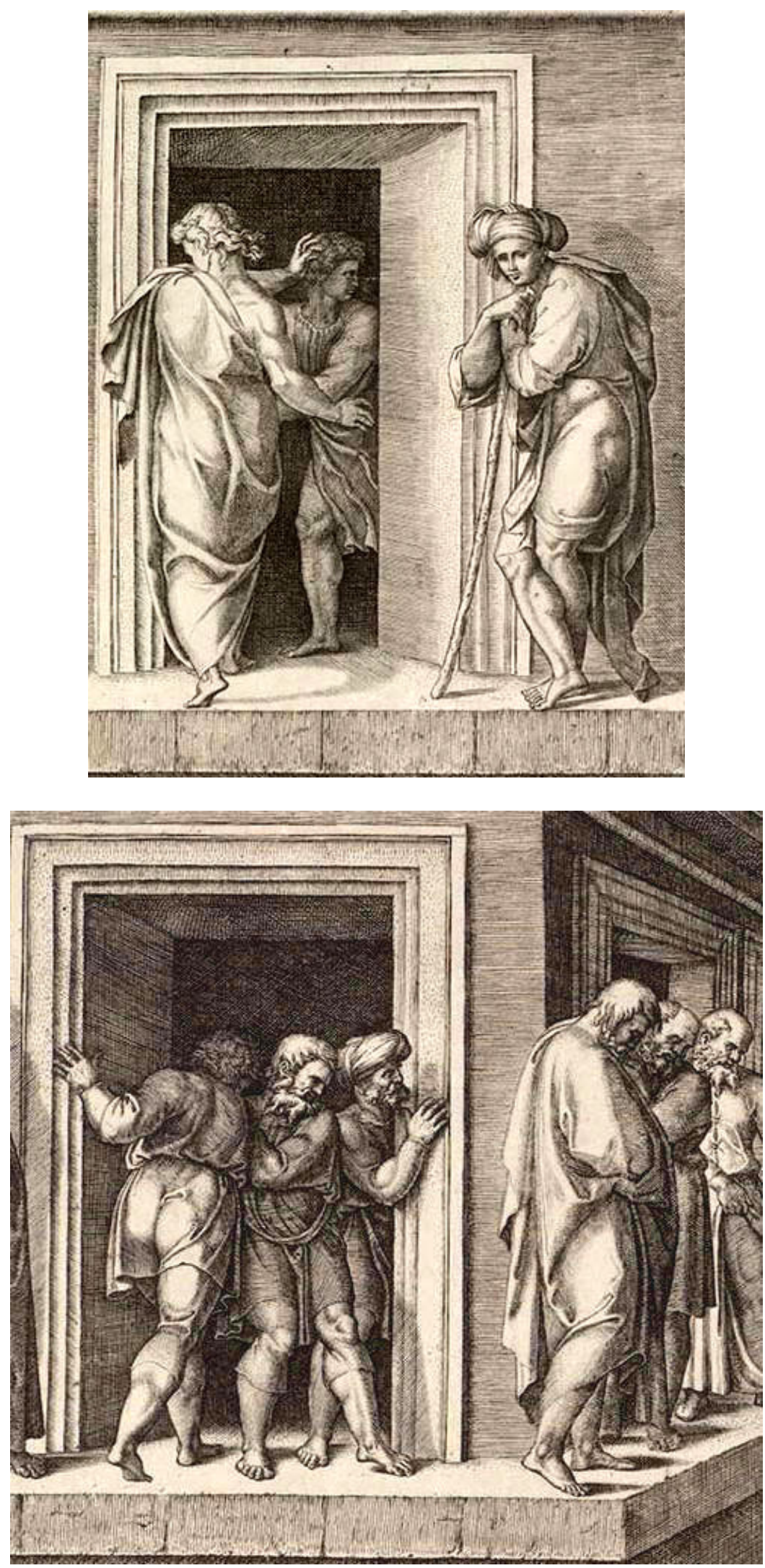

-El Martirio de San Lorenzo. Dos grupos de espectadores. Detalles. 
La producción de Marcantonio Raimondi y su taller, además de las obras en las que pesa más el aspecto interpretativo de los resultados de su trabajo que el meramente reproductivo, comprende una enorme serie de obras de pequeño formato que recrean y transmiten a un público necesitado de ello un completo panorama iconográfico del arte romano renacentista. Por iniciativa propia o respondiendo a encargos de editores, figura empresarial nueva que se mezcla con el librero e incluso con el banquero, esa producción menor aunque solo sea por las dimensiones, coexiste con la interpretativa e igual que esta, se difunde por toda Europa sirviendo para varios fines, entre ellos nutrir las escuelas de dibujantes de las futuras academias.

Se graban y vuelven a grabar, por el mismo Marcantonio o por sus ayudantes, apostolados, santorales, papas y césares o personajes mitológicos, sintetizando visualmente imagen y técnica con extraordinarios resultados en muchas ocasiones.

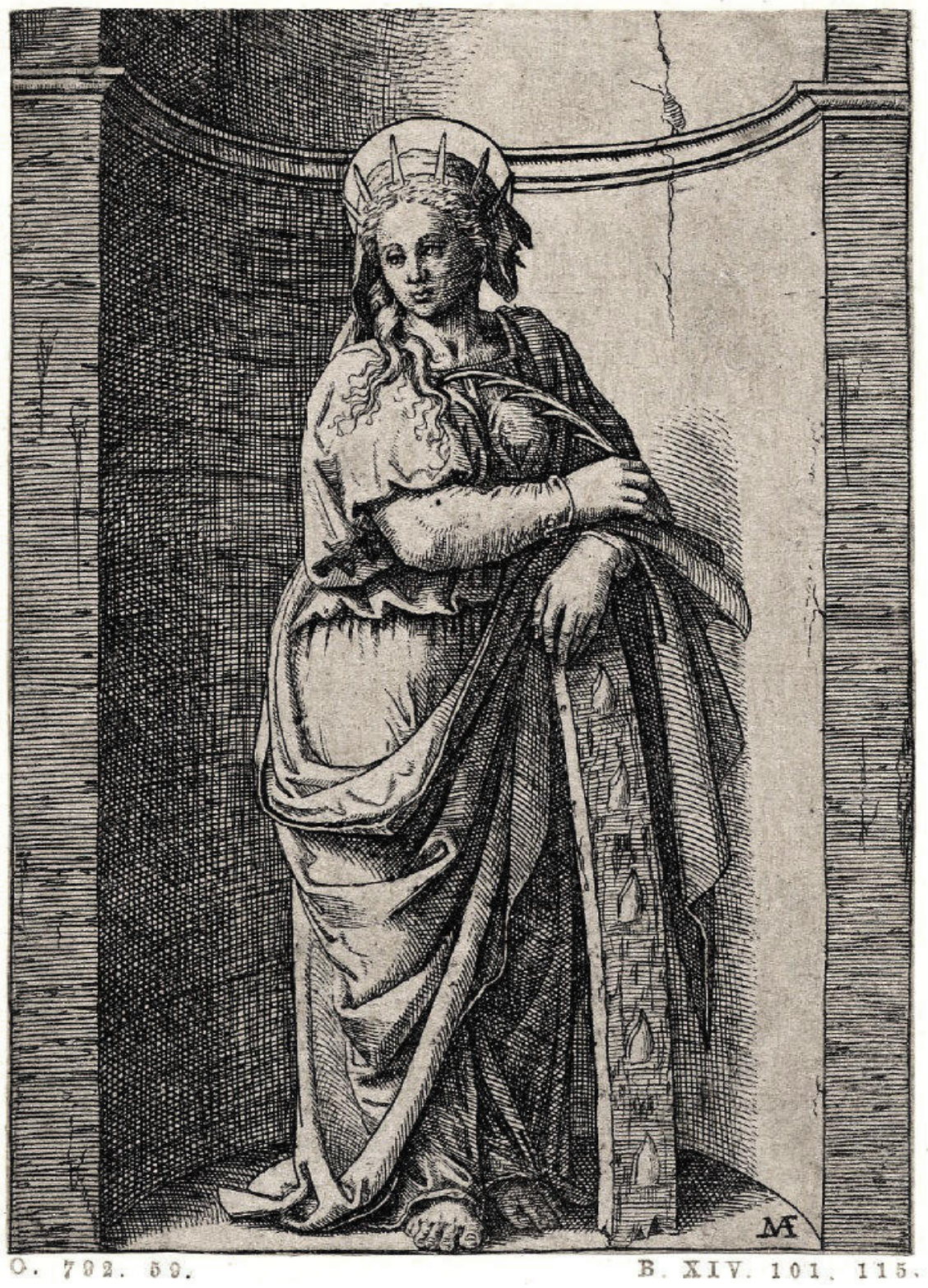

- Marcantonio Raimondi. Santa Catalina. Buril. (107 x 79 mm.) 1511-27. 

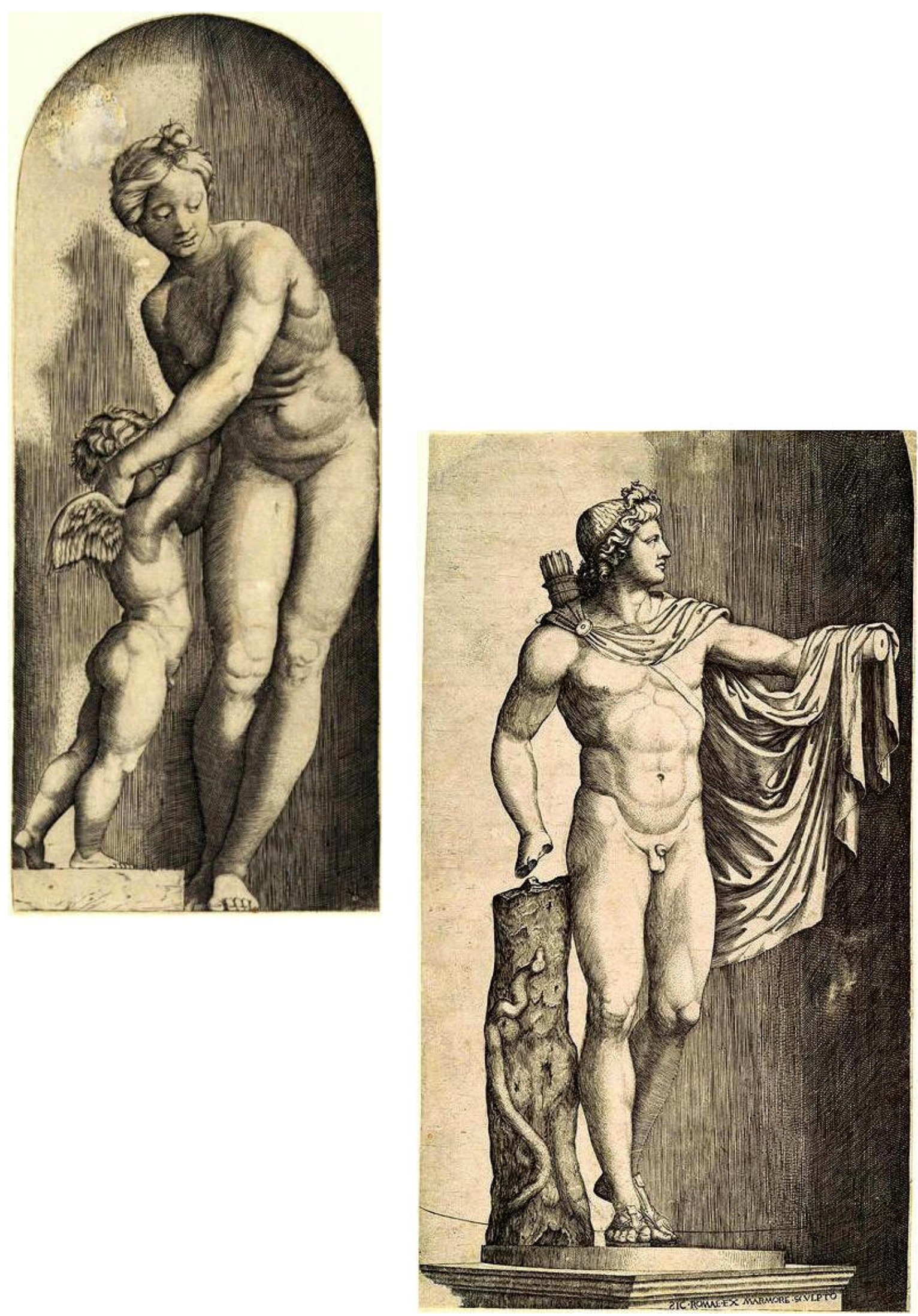

- Marcantonio Raimondi, Venus y Cupido según Rafael y Apolo Bevedere. 1511-34. 


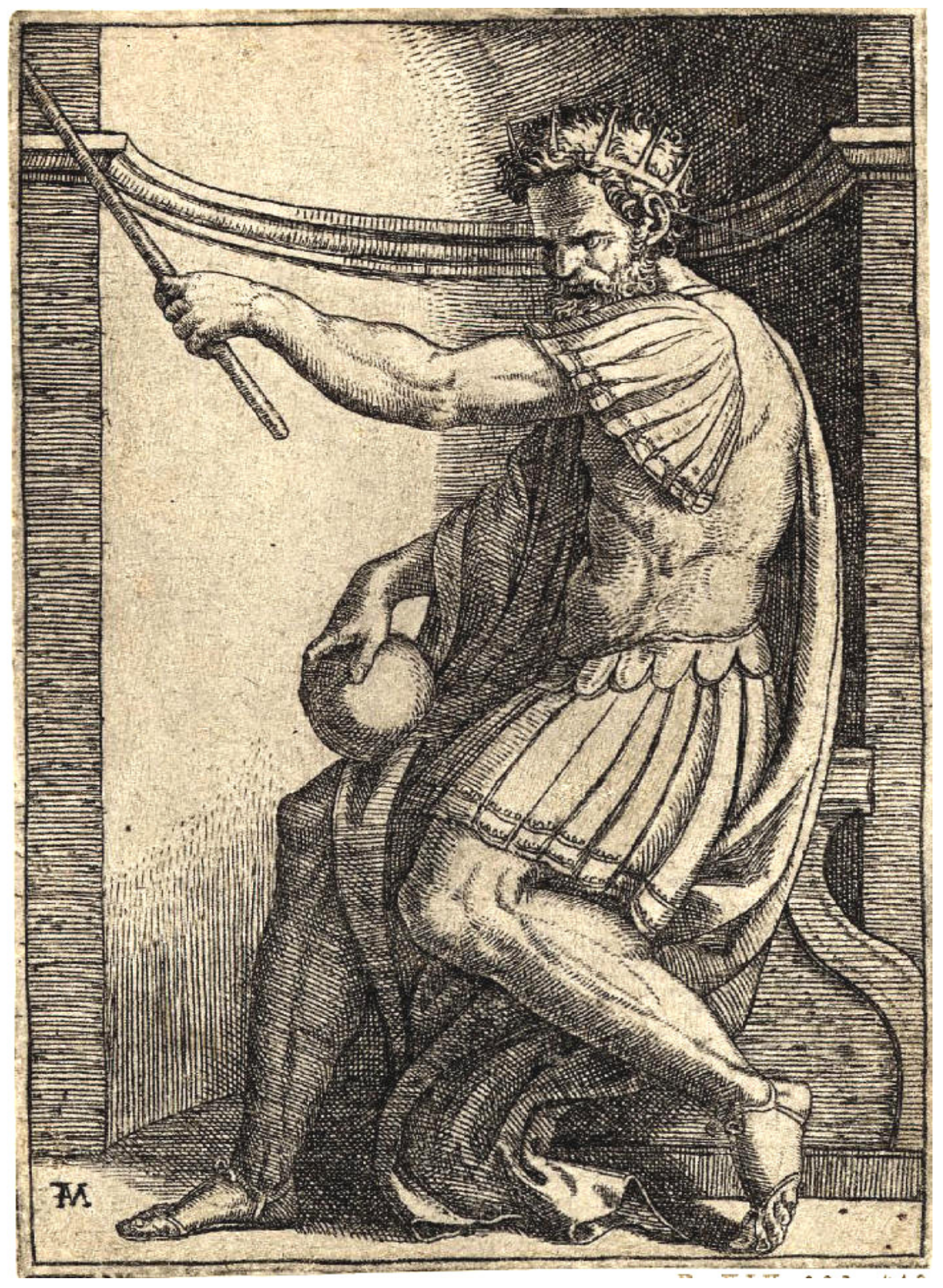

-Marcantonio Raimondi, Emperador romano en un nicho. 1811-27. 

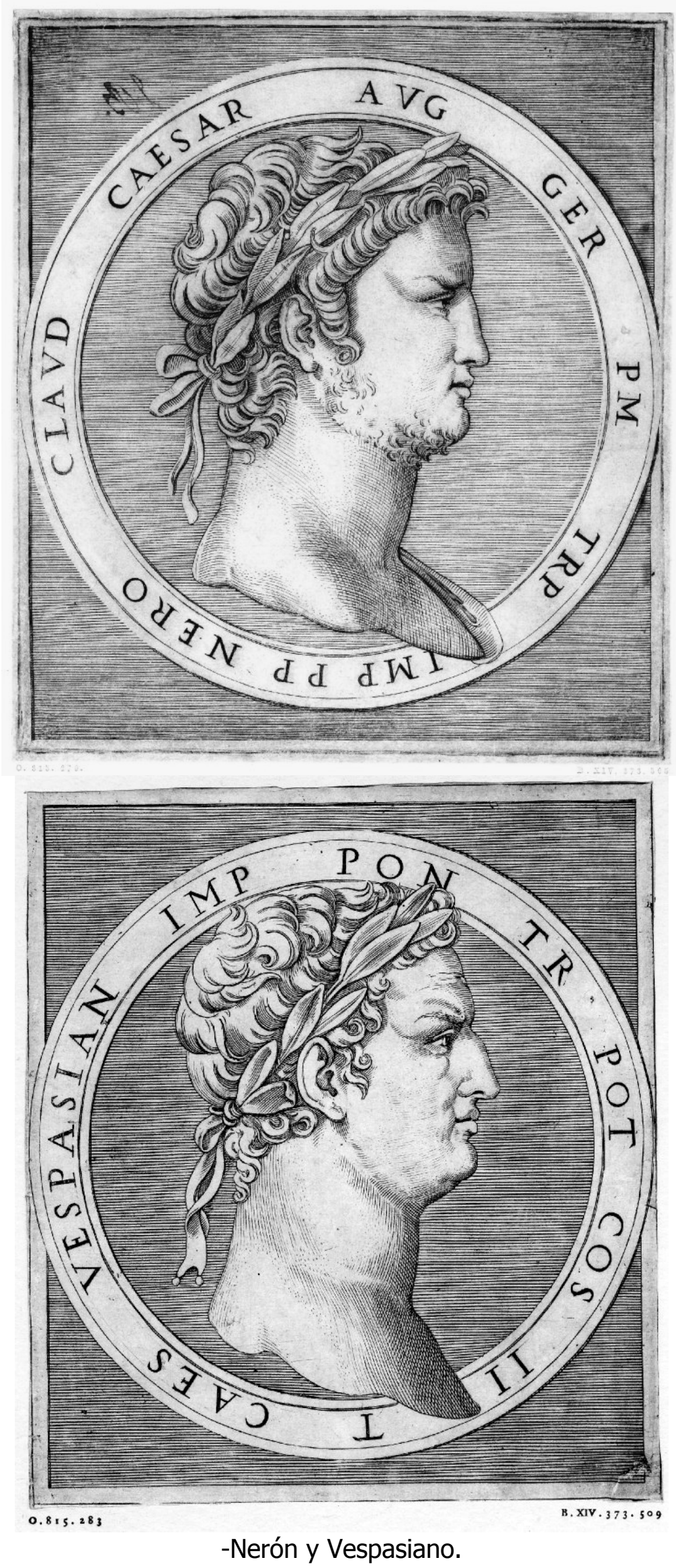


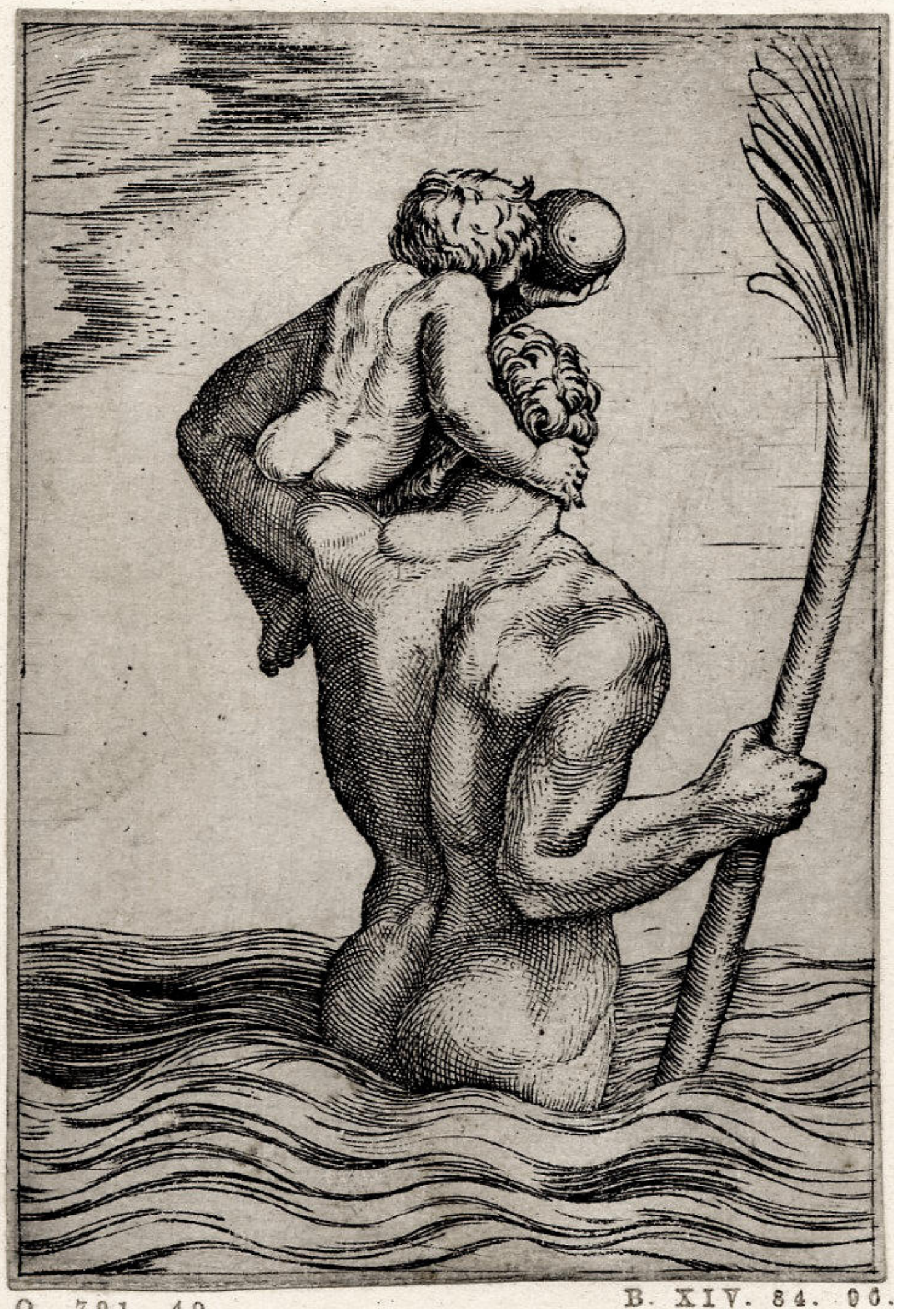

- Marcantonio Raimondi, San Cristóbal. 1511-30 


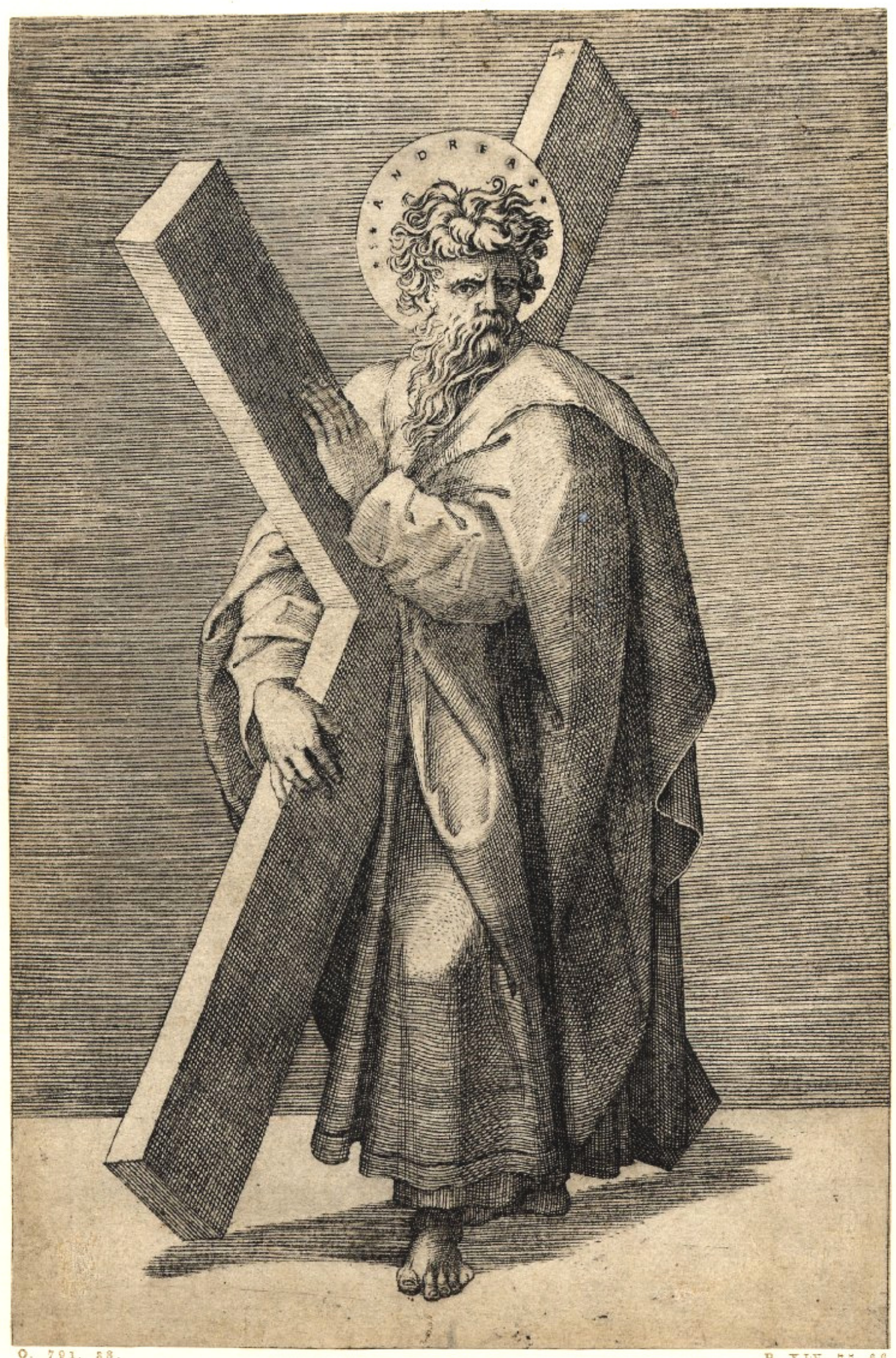

- Marcantonio Raimondi, San Andrés. 1511-30. 


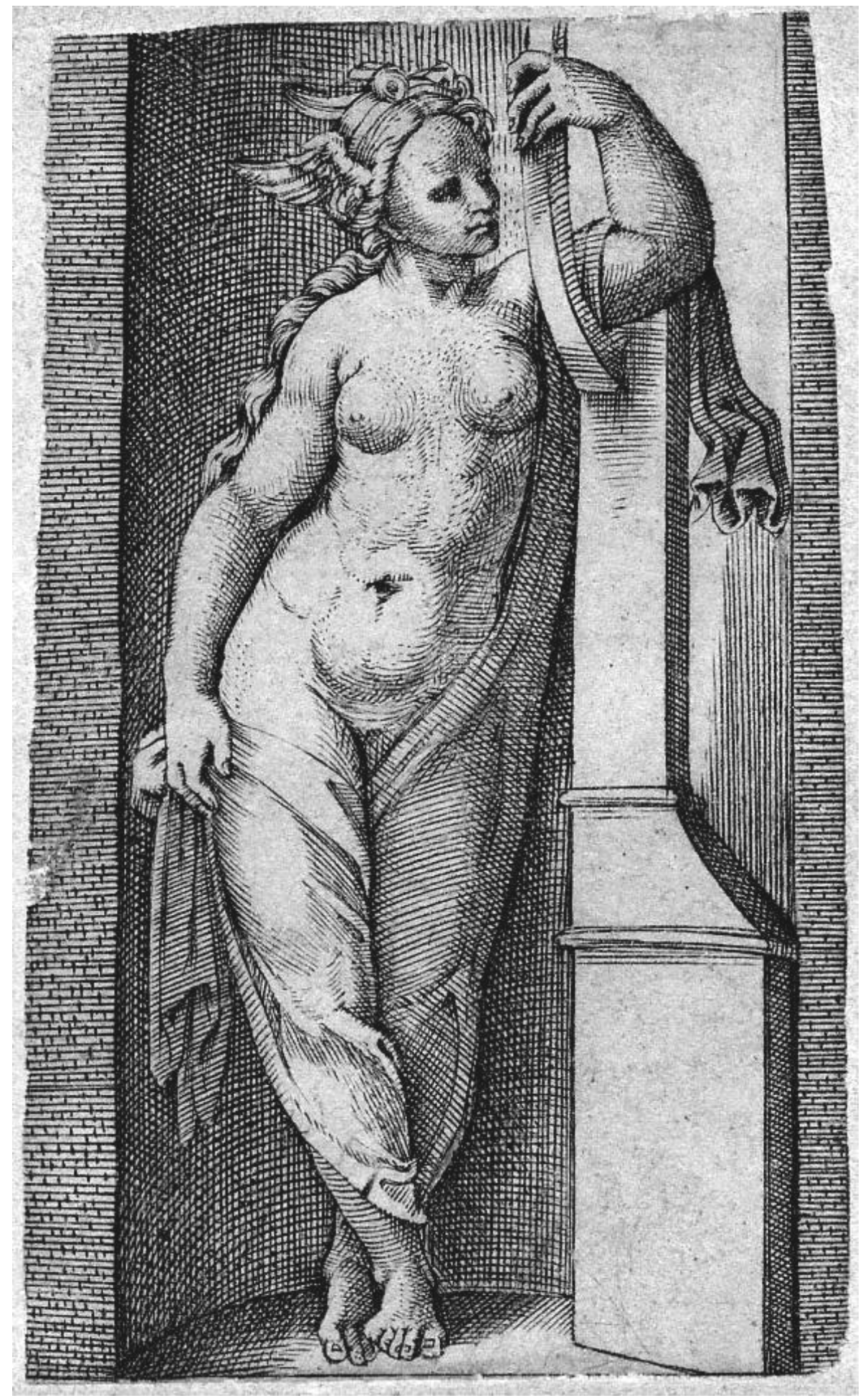

-Marcantonio Raimondi. Deidad con casco alado en un nicho. 1511-27.

Los personajes, figuran aislados e individualizados sobre fondos neutros de líneas cruzadas y de paralelas, carecen de contexto narrativo y se convierten en tipos y guía de devoción y aprendizaje, su monumentalidad en pequeñas dimensiones (entre $10 \mathrm{o}$ 12 por 6 u $8 \mathrm{~cm}$. o incluso menos), responde a la concepción escultórica que de los volúmenes y el cuerpo humano tuvo Raimondi. 


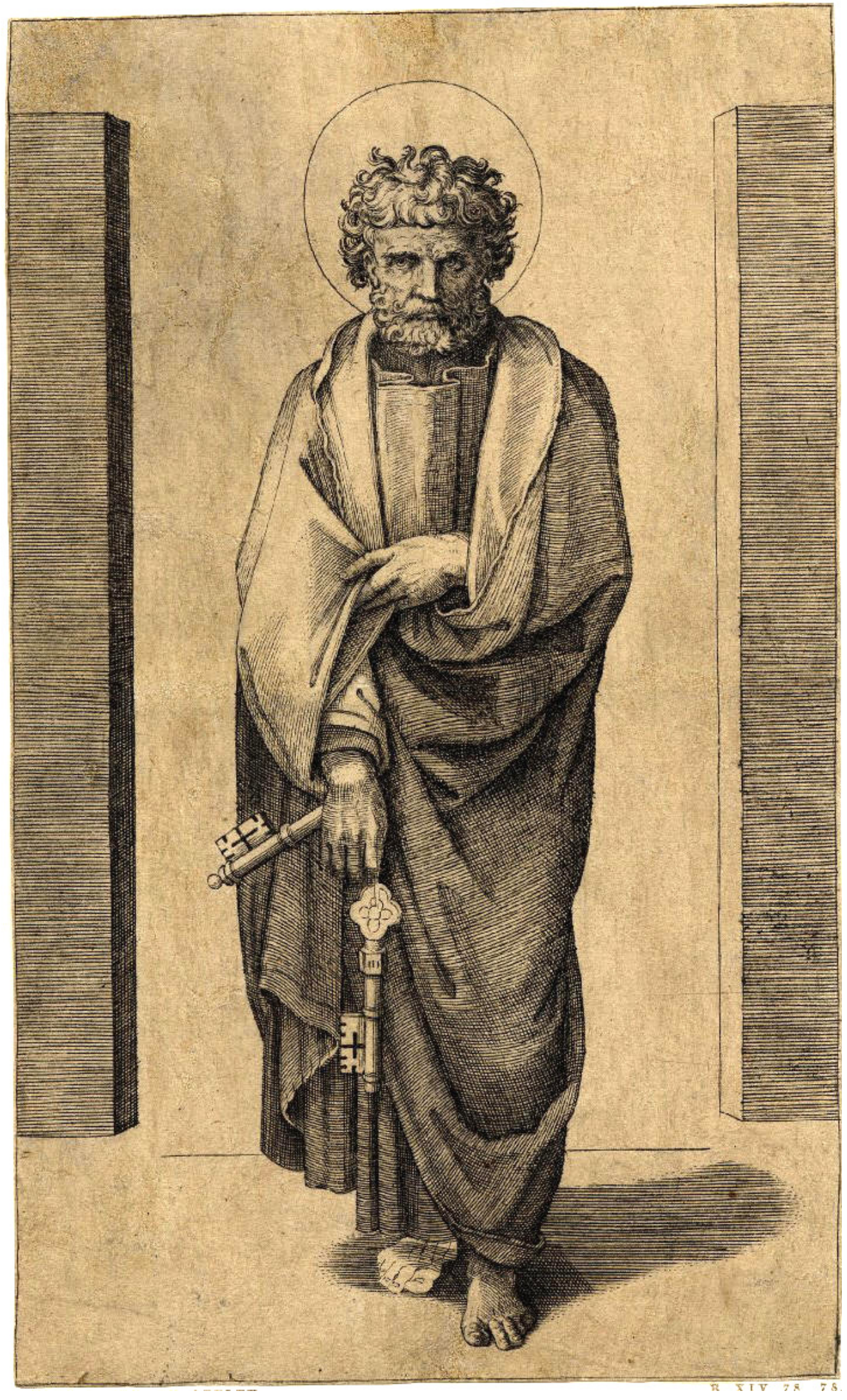

-Marcantonio Raimondi. San Pedro. 1511-27. 

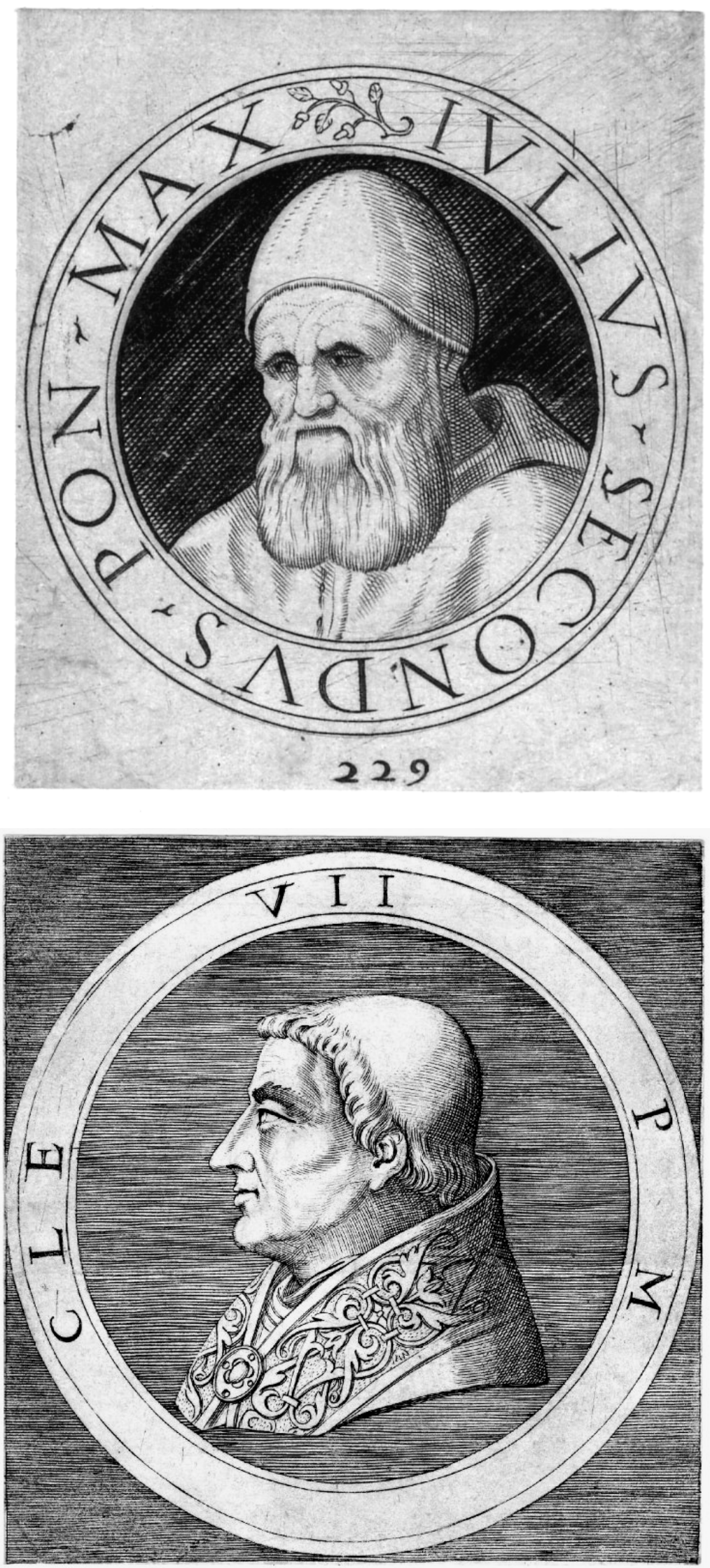

- Julio II y Clemente VII. 


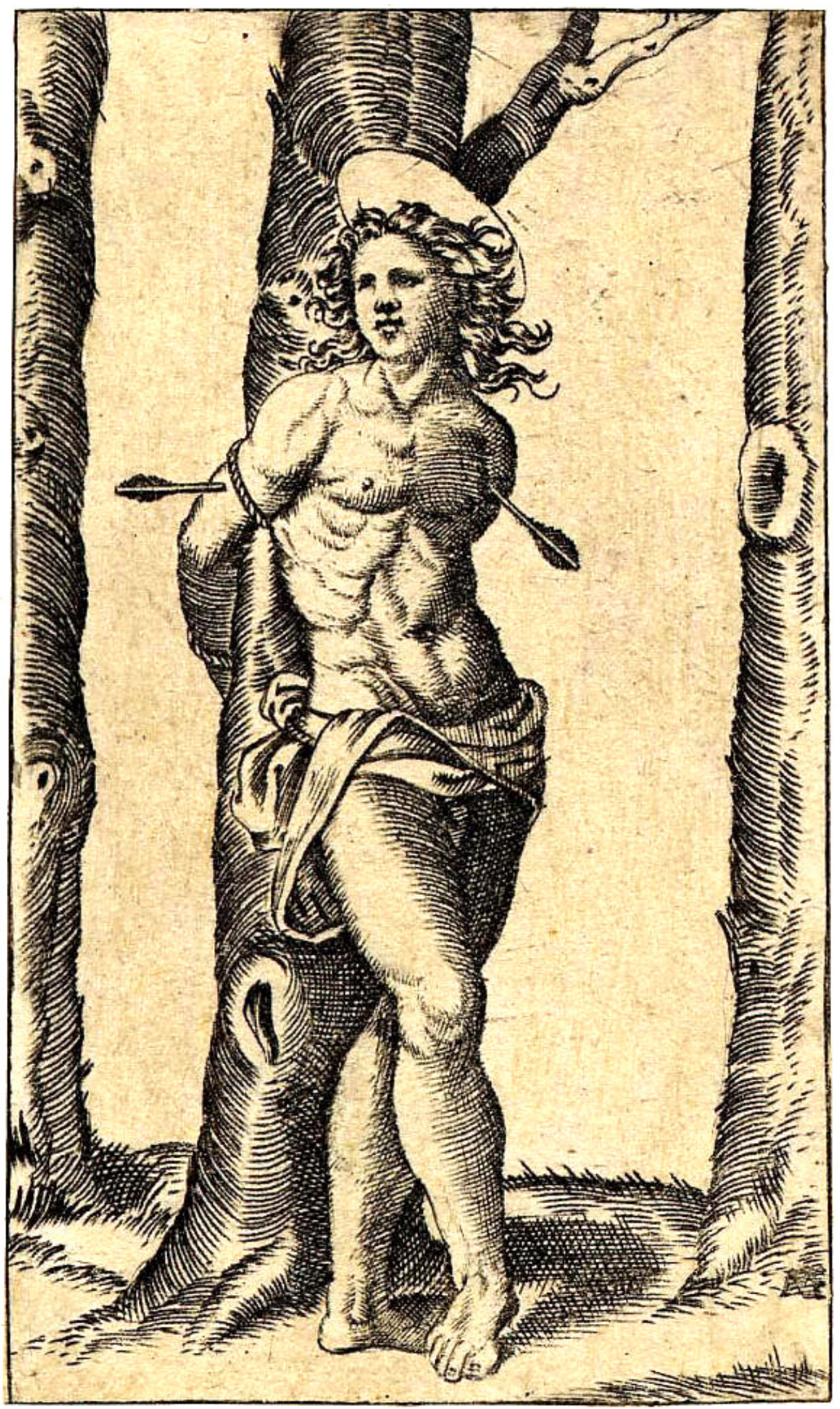

- Marcantonio Raimondi según Rafael. San Sebastián. 1511-27. $81 \times 48 \mathrm{~mm}$. 


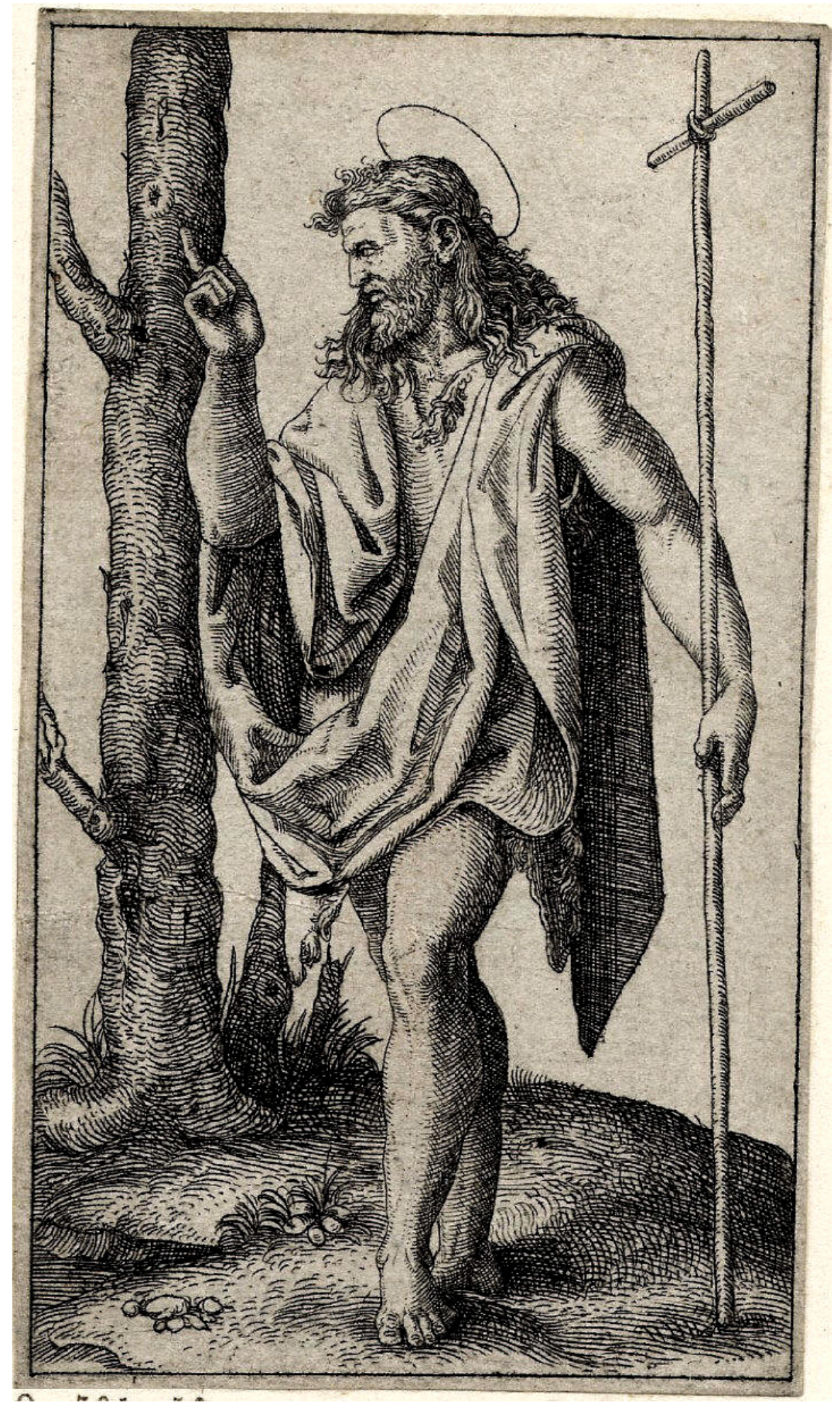

- Marcantonio Raimondi, San Juan Bautista. Buril. 1511-27. 


\section{La Escuela de Marcantonio Raimondi.}

Marco Dente o Marco da Ravenna, nace en esta ciudad en fecha desconocida y muere asesinado en Roma durante el saqueo de la ciudad en 1527. Su primera estampa fechada es de 1515 y es probable que desde la asociación laboral entre Marcantonio y Rafael formara parte de este círculo artístico. La evolución de su estilo pasa por una primera fase de asimilación del código gráfico de Raimondi de quien reproduciría numerosas obras, tanto de los trabajos interpretativos más destacados, como de las obras meramente comerciales de menor formato. También produciría trabajos personales según originales de Rafael y su círculo, Julio Romano y Baccio Bandinelli.

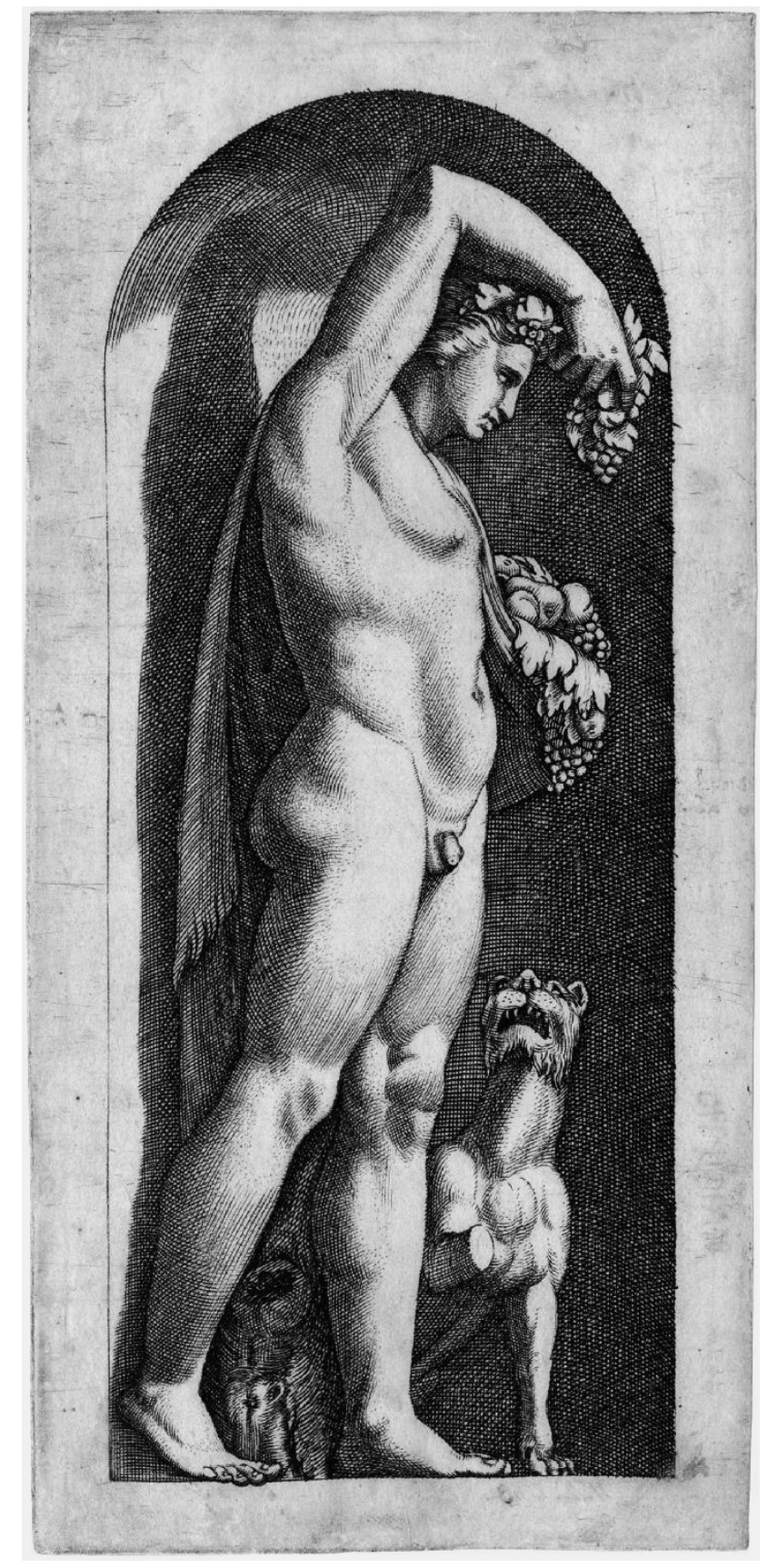

- Marco da Ravenna. Baco. Buril. 1510-27. 
No llegará a asimilar completamente las sutilidades de Marcantonio sugiriendo atmósferas y controlando la luz mediante las transiciones tonales, aún así su obra progresará a lo largo de su vida notablemente.

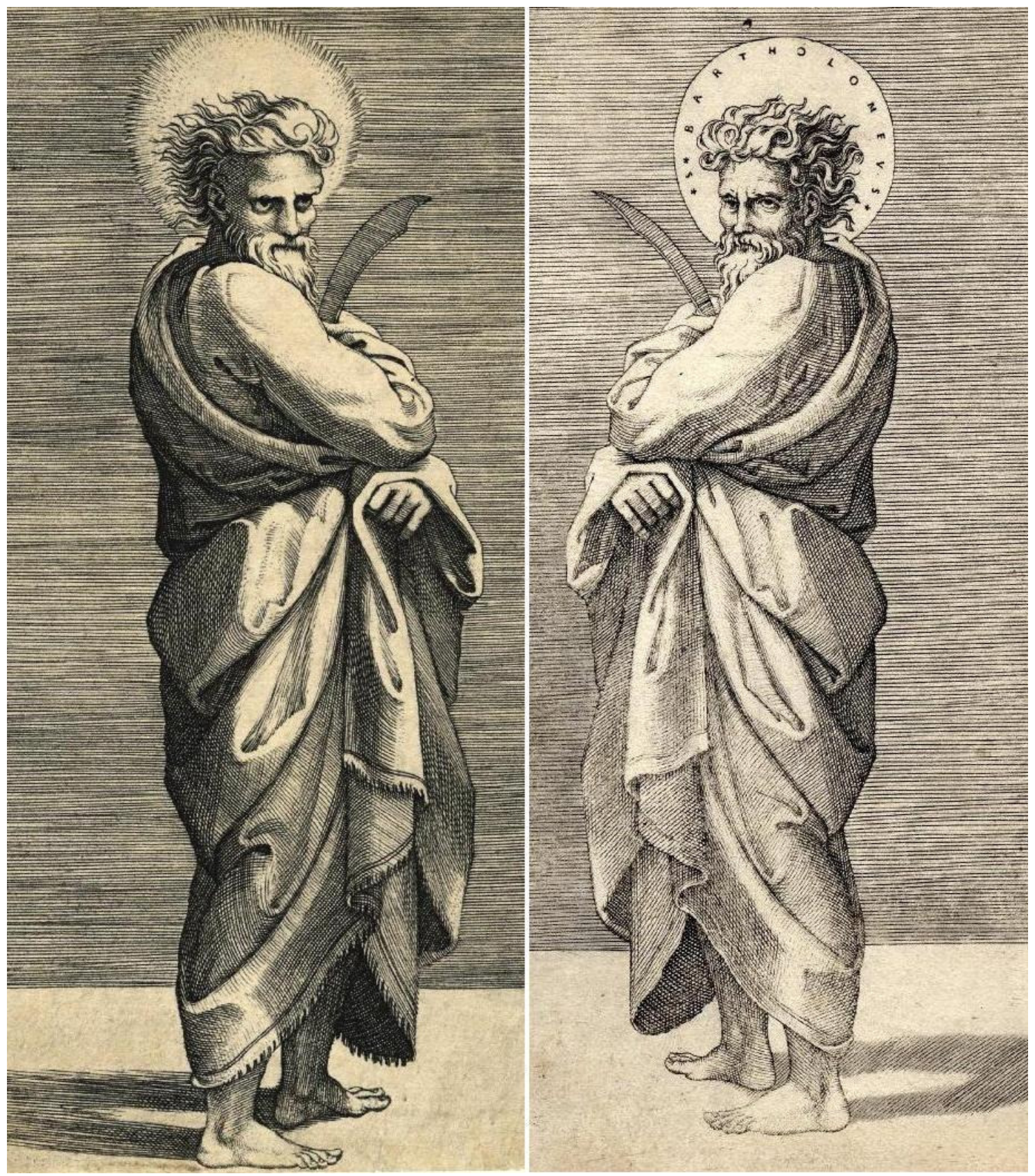

- Marco da Ravenna y Marcantonio Raimondi. San Bartolomé. Fragmentos.

Las obras de los colaboradores de la escuela romana de Marcantonio también tendrían una enorme difusión y serían utilizadas como modelo de aprendizaje, en talleres cerámicos y como referentes iconográficos de la cultura visual renacentista y la mitología grecorromana. 

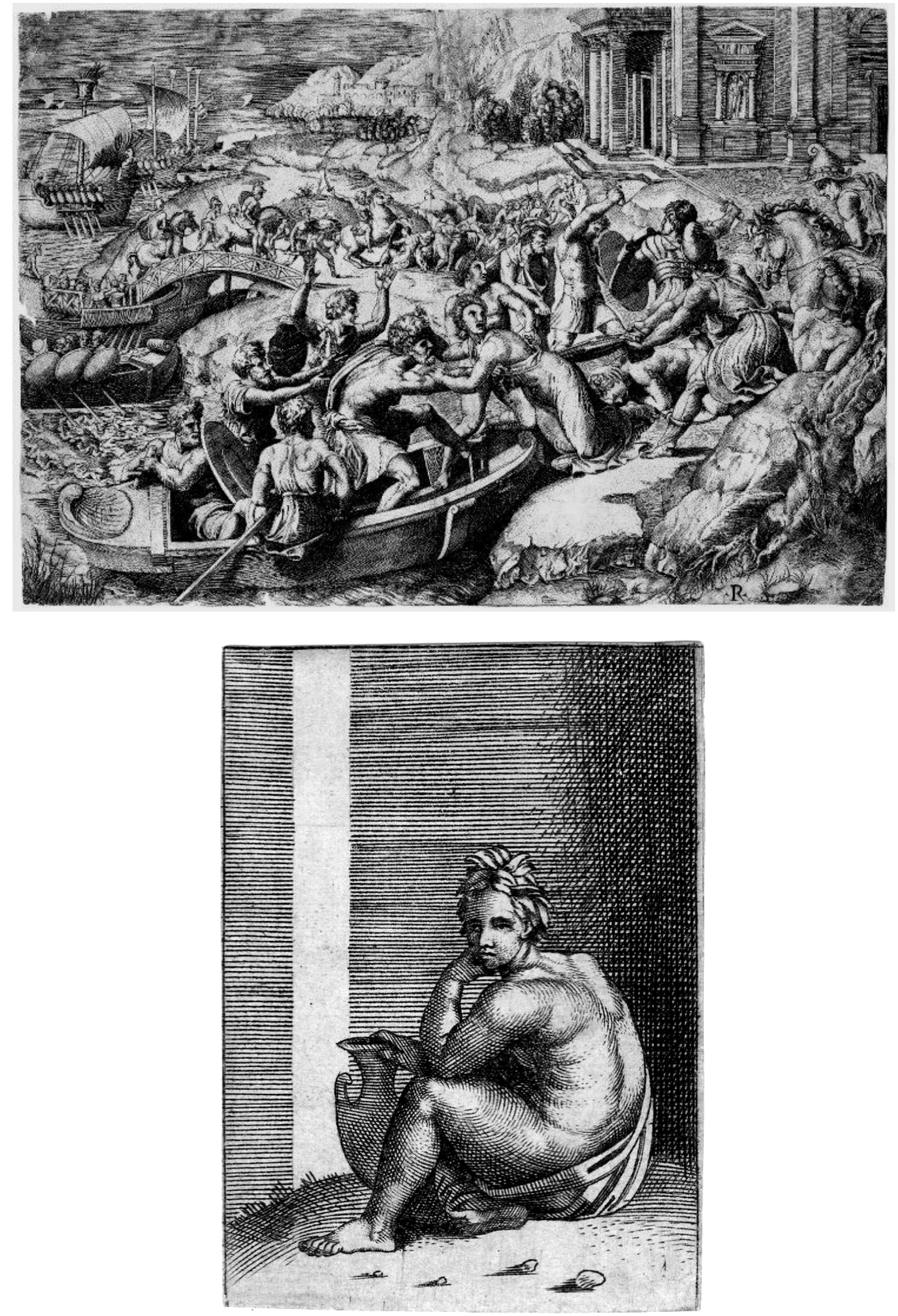

- Marco da Ravenna según Marcantonio. El Rapto de Helena y figura sentada extraída de El Juicio de Paris de Marcantonio. Buril. 1515-19. 


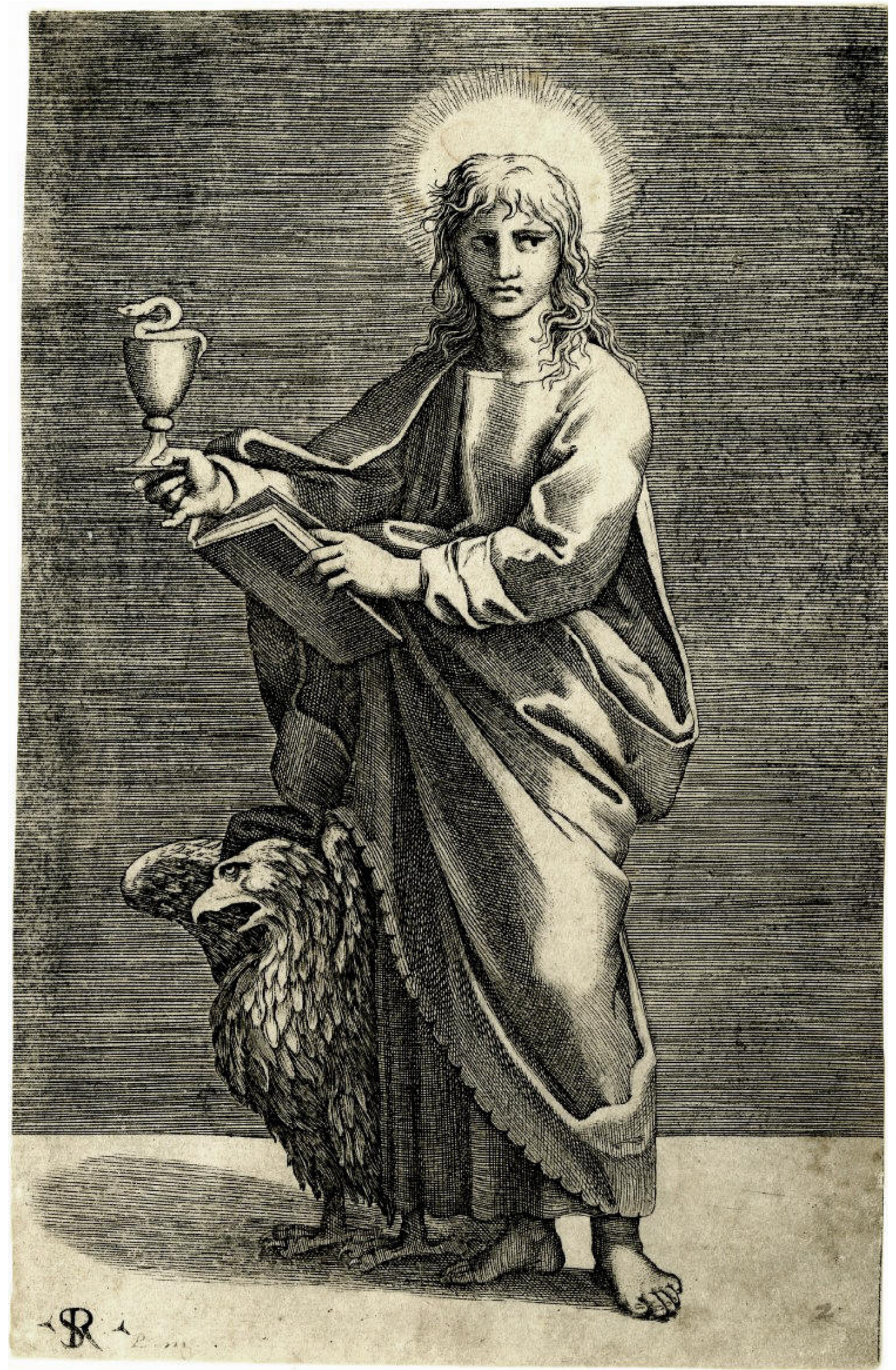

- Marco da Ravenna. San Juan Evangelista según Marcantonio. Buril. 1515-27. 


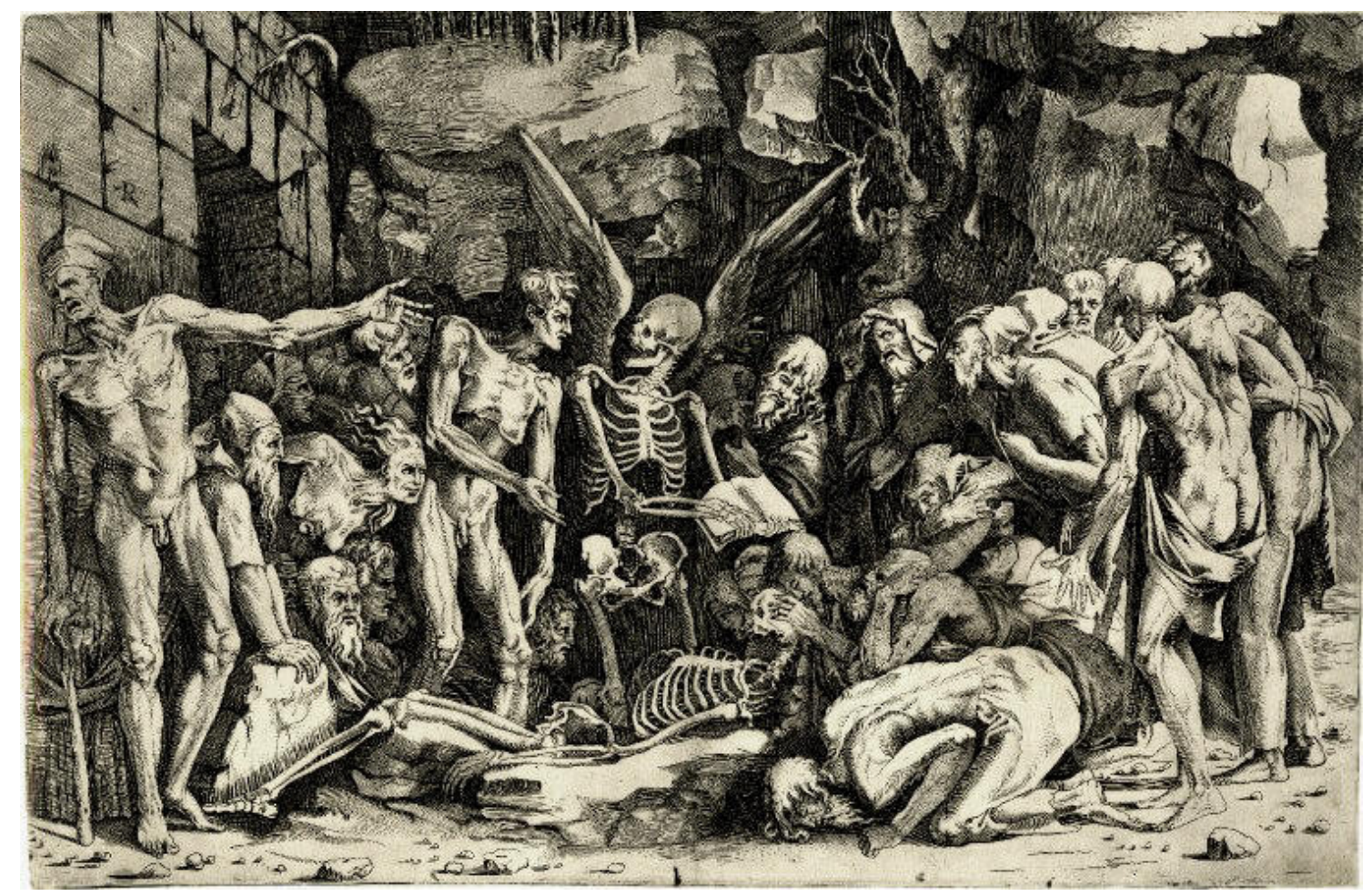

- Marco da Ravenna según Bandinelli. Esqueletos. Buril.1518-25.

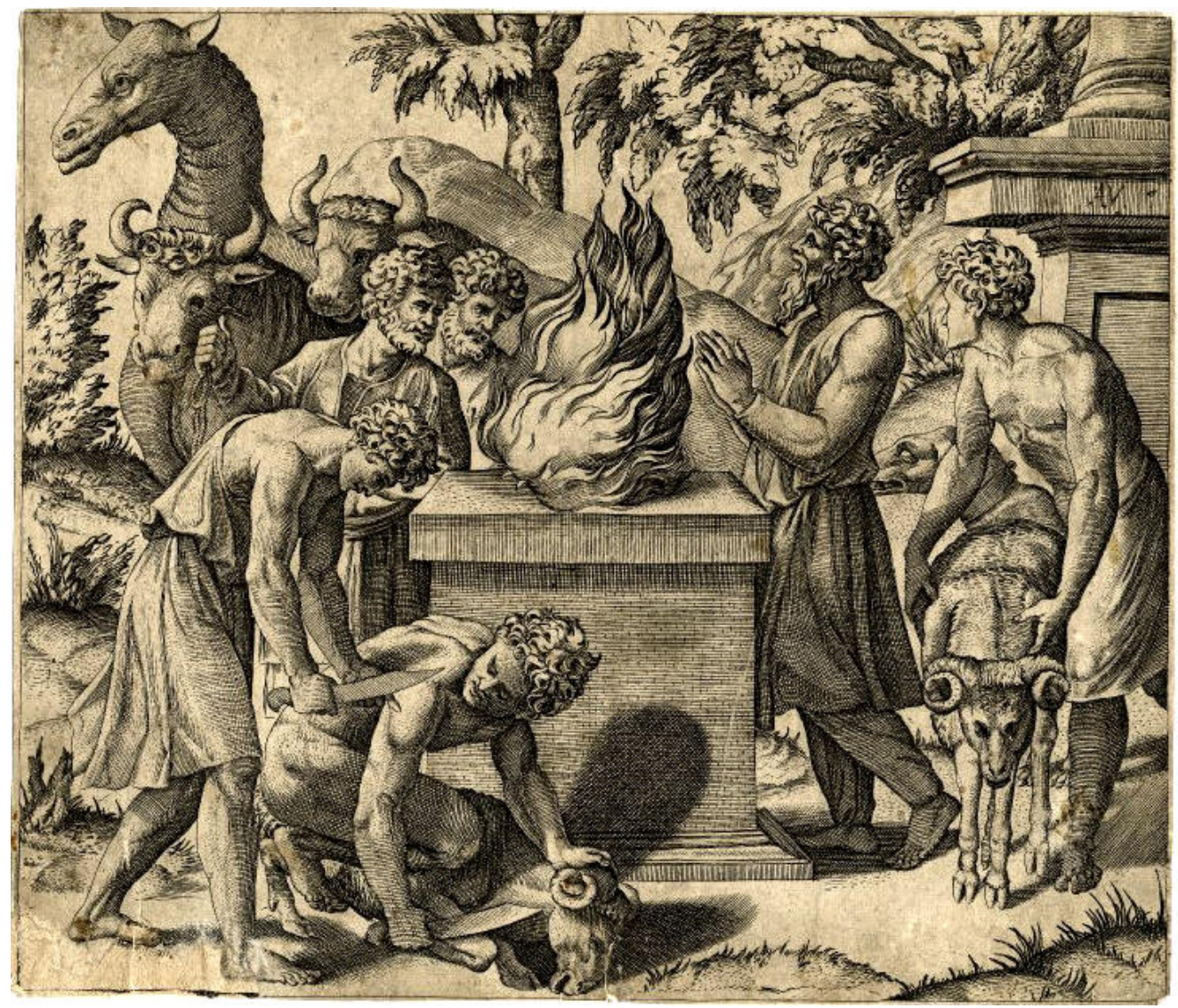

- Marco da Ravenna. El Sacrificio de Noé. Buril. 1517-27. 


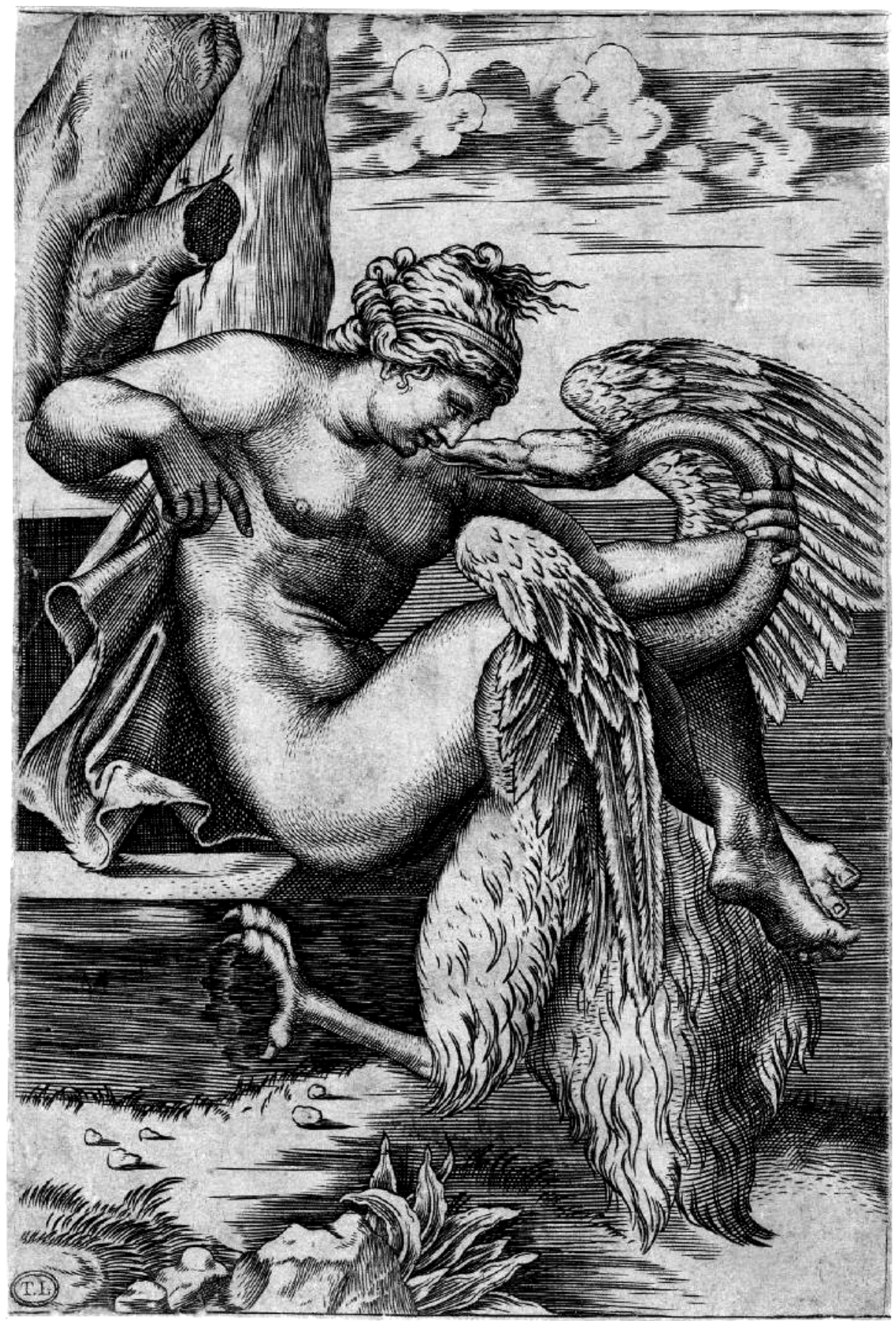

-Marco da Ravenna según Julio Romano. Leda y el Cisne. Buril. 1510-27.

Los trazos paralelos de buril no definen con exactitud los volúmenes anatómicos que como consecuencia pueden parecer algo aplanados, en la figura de Leda, pecho y pierna izquierdos y mano derecha. El rayado de los elementos ajenos a la figura principal es menos cuidadoso que en esta. En toda su obra tiende a contrastar zonas fuertemente iluminadas con otras muy oscurecidas y a remarcar fuertemente las líneas de contorno y los ojos de los personajes. La monumentalidad, que no falta en sus personajes, es algo plana y estática comparada con la de Marcantonio. 
Los fondos de sus composiciones suelen ser mucho más cargados y suntuosos que los de Raimondi y en ocasiones las figuras parecen flotar aislados de ellos.

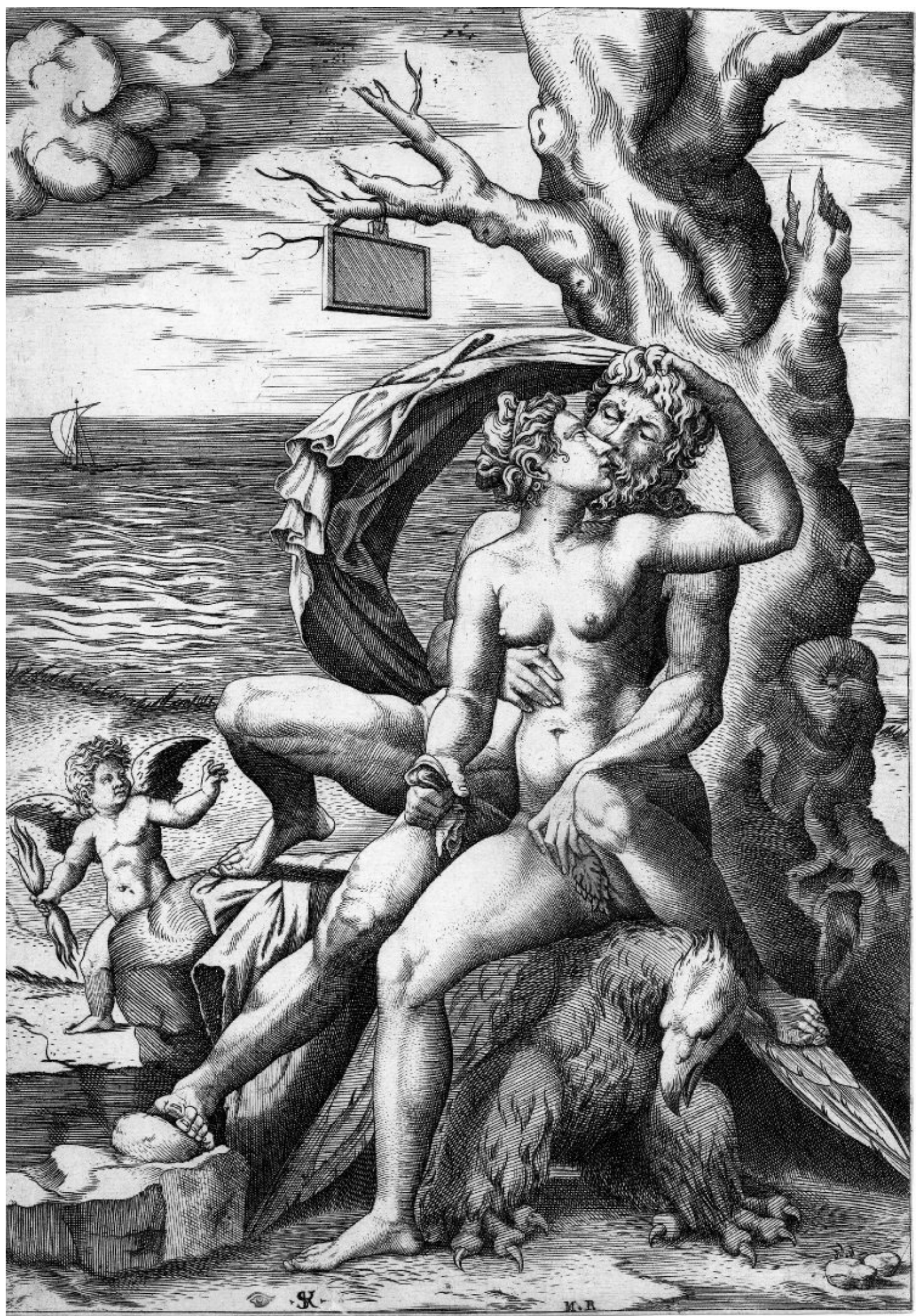

- Marco da Ravenna según Julio Romano. Júpiter y Semele. Buril. 1510-20. 


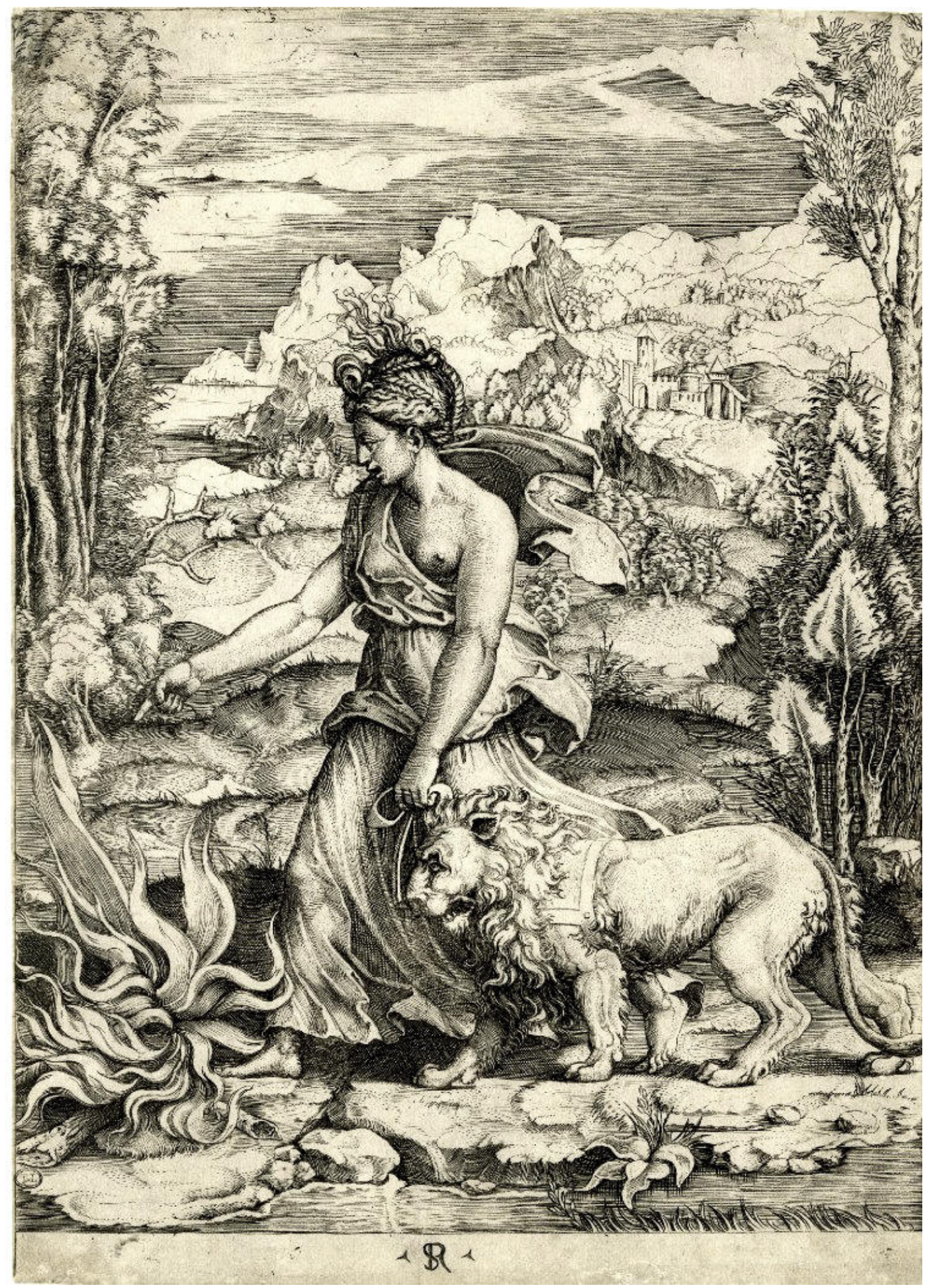

- Marco da Ravenna. Fortaleza. Buril. 1515-27.

En ocasiones alcanza grandes resultados como en esta obra claramente dependiente de los grabados de Durero. 


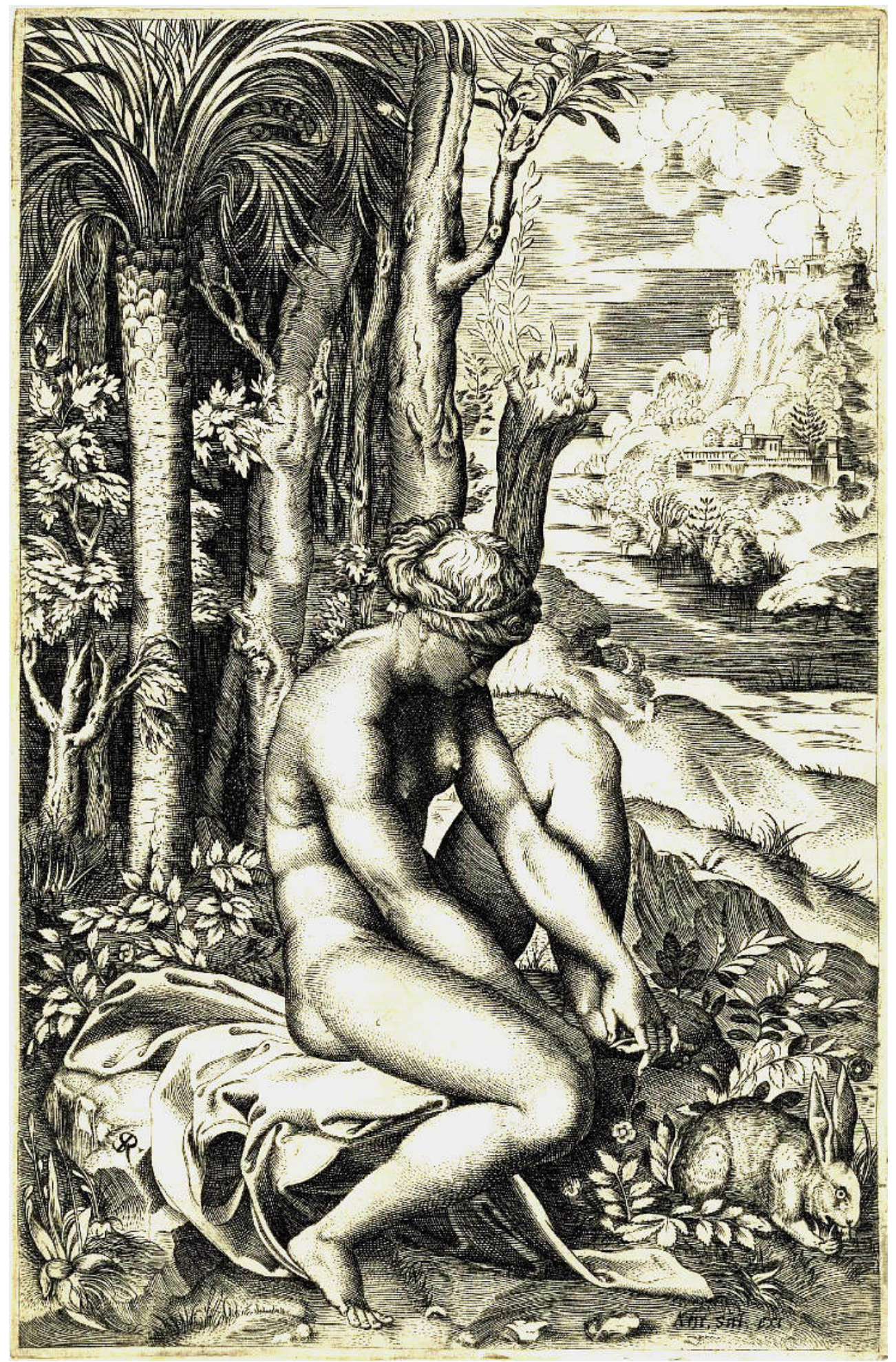

- Marco da Ravenna según Rafael o Julio Romano. Venus herida por la espina de una rosa. Buril. 1516.

Esta es una de las mejores composiciones del autor. El contraste entre el fondo montañoso fuertemente iluminado y la detallada masa de árboles muy sombreados en la que sitúa a Venus, ambos derivados de la obra de Durero, la contrastada figura de la diosa y su bien conseguido carácter escultórico, forman un conjunto muy armonioso. 


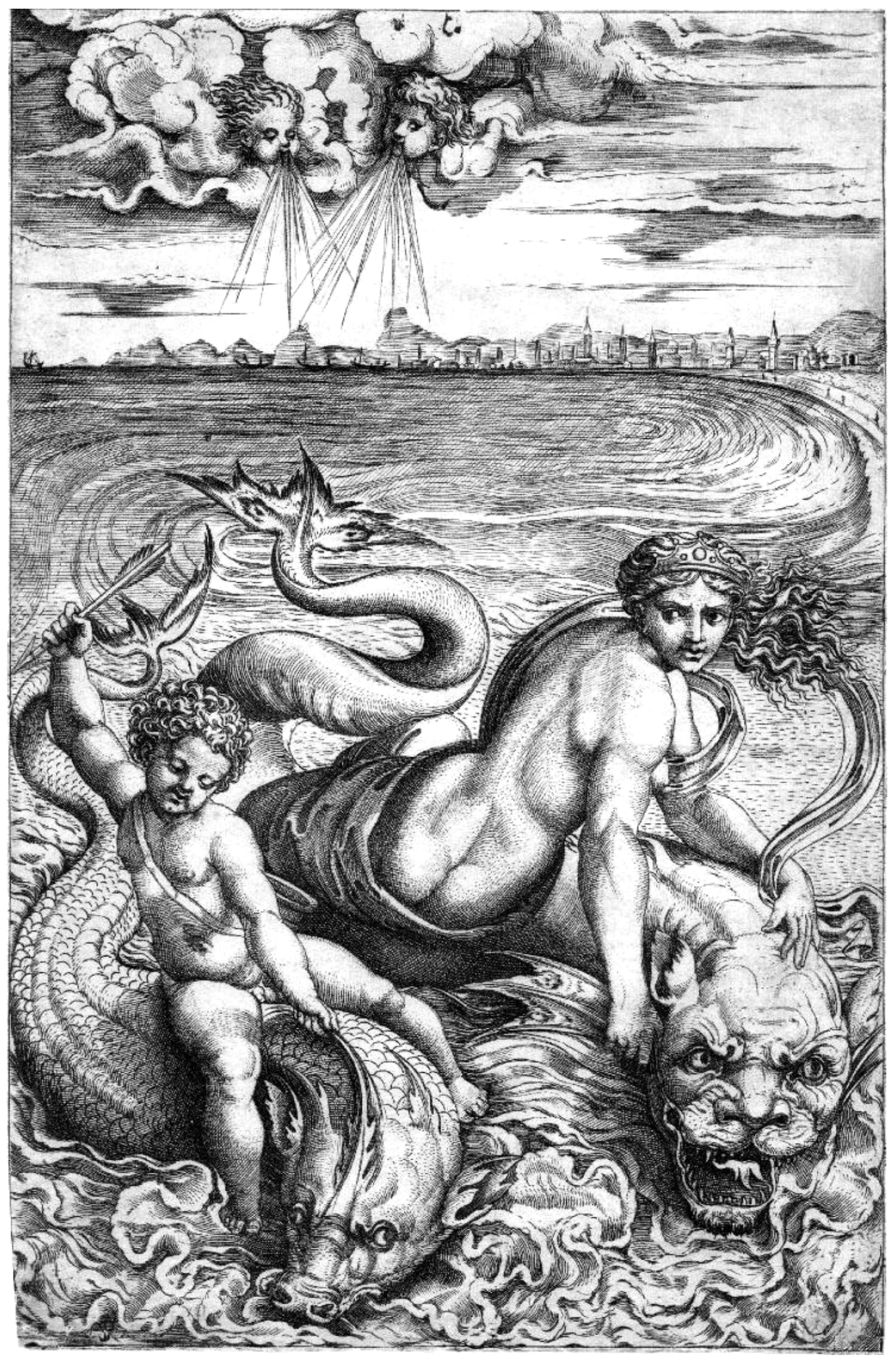

-Marco da Ravenna y Agostino Veneziano. Venus y Cupido cabalgando dos Bestias Marinas. Buril. 1515-20. 
No son pocos los trabajos de incierta atribución, en "Venus y Cupido cabalgando dos Bestias Marinas", parece probada la colaboración entre Marco da Ravenna Y Agostino Veneziano y según las fuentes puede aparecer adjudicada a uno u otro.

Agostino dei Musi (1480-1540), llamado Agostino Veneziano por su origen, se forma en su ciudad natal siendo influenciado por el grabador Campagnola. Reside brevemente en Florencia trabajando según obras de Bandinelli. Ubicado en Roma sobre 1516, pasa en esas mismas fechas a formar parte del círculo de trabajo de Raimondi y Rafael.

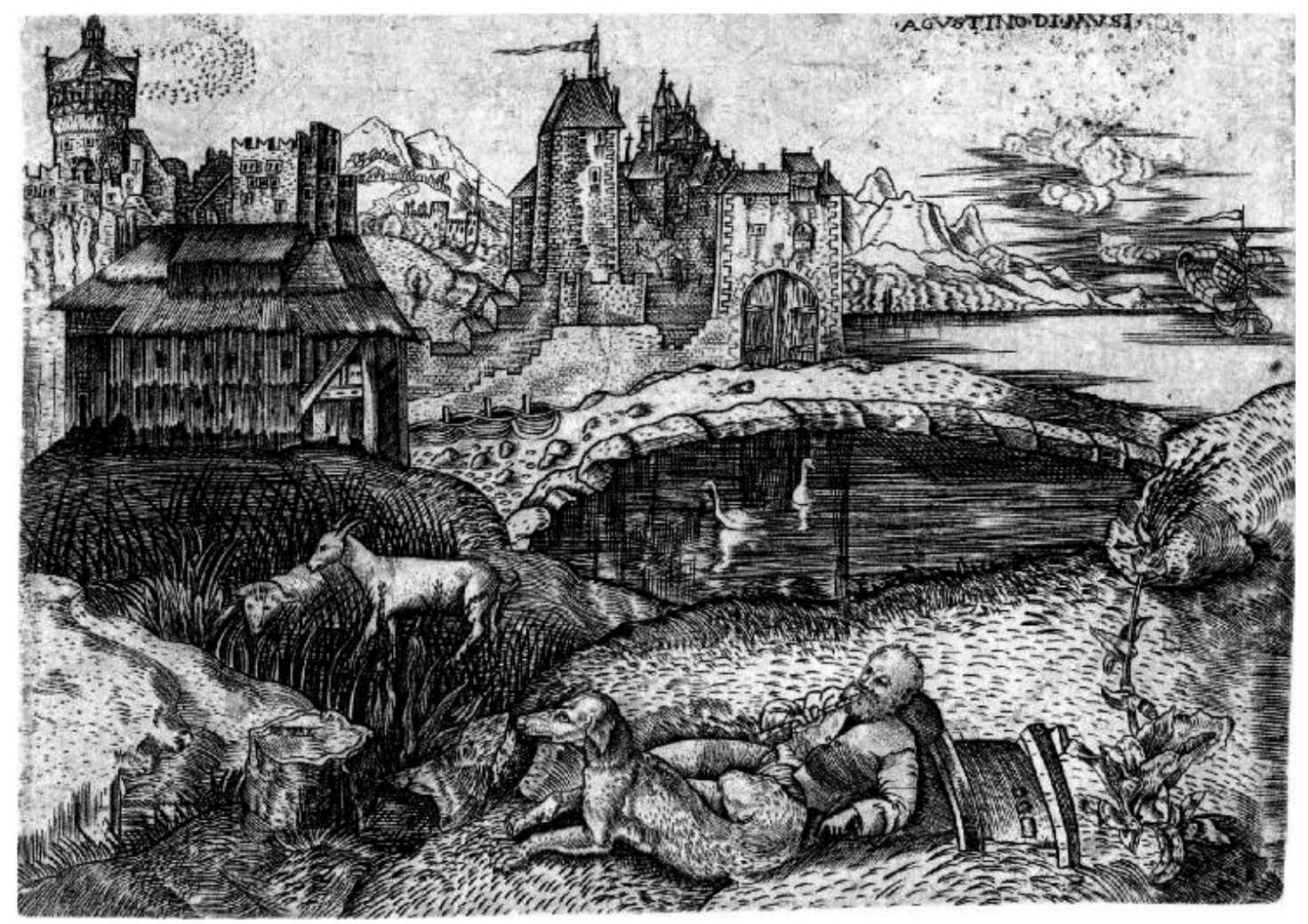

- Agostino Veneziano según Campagnola. Hombre descansando. Buril. 1510-15.

Su obra y otras relacionadas con ella, es fácilmente fechable gracias a su costumbre de datar las matrices. Sobrevivió al Saco de Roma y permaneció en la ciudad, haciendo trabajos de distintos orígenes. Además de los grabados de reproducción trabajó retratos, vistas de pájaro y repertorios arquitectónicos. Su trayectoria junto a Marcantonio Raimondi se inicia con el aprendizaje del código gráfico establecido por este. En su técnica particular aparece el gusto por los diferentes trazados que generan los distintos tipos de buril, algo que Marcantonio no contemplaba. Reproducirá, igual que Marco da Ravenna y los demás colaboradores del taller, obras de todo tipo creadas por Marcantonio y según originales del circulo de Rafael, Andrea del Sarto, Baccio Bandinelli y Julio Romano.

De formación claramente veneciana, hereda tratamientos de Julio Campagnola, como puntear zonas de la superficie de la plancha y delinear con gran meticulosidad, eligiendo en muchas ocasiones grandes espacios abiertos para ubicar a sus personajes. 


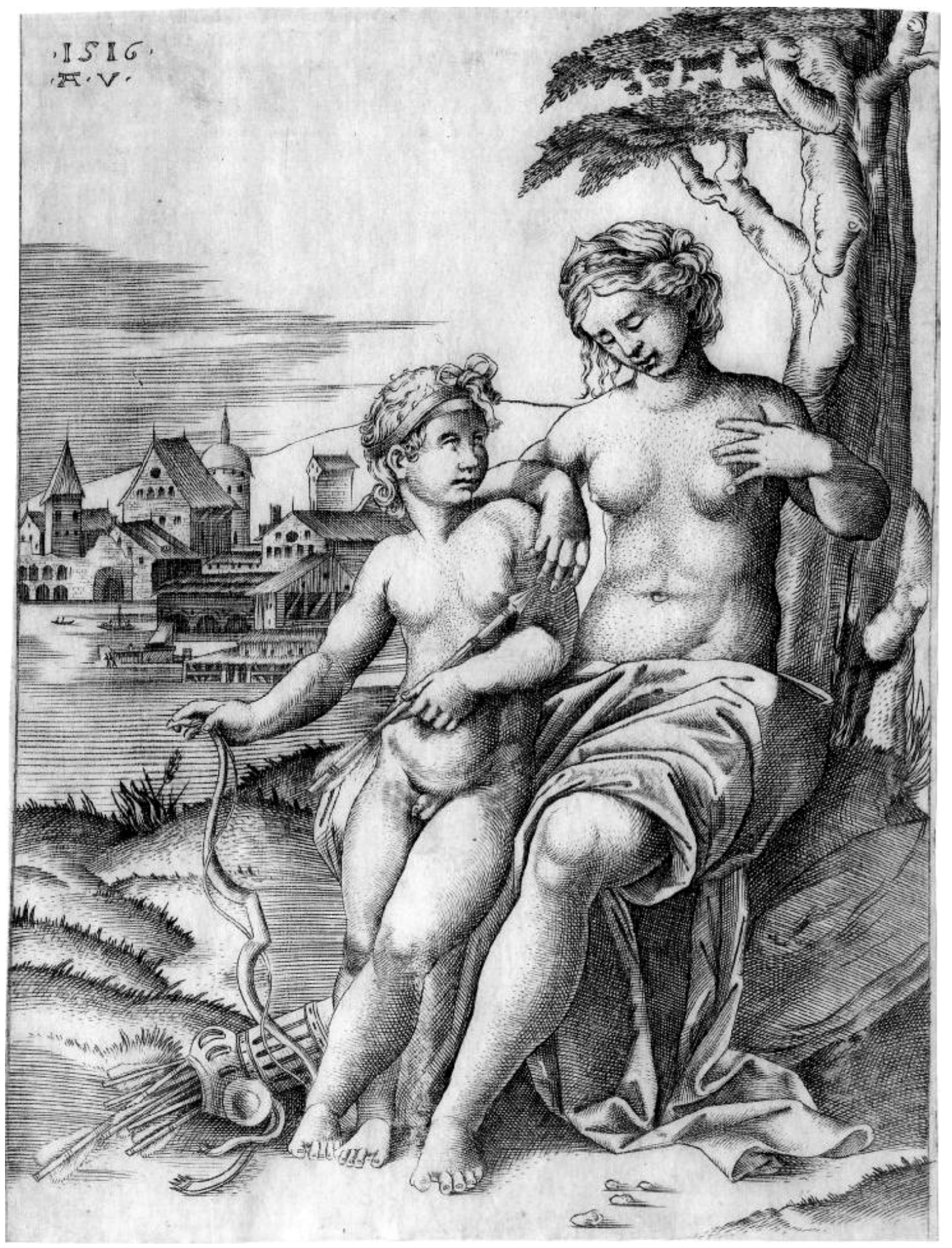

-Agostino Veneziano según Rafael. Venus herida por las flechas de Cupido. Buril. 1516. 


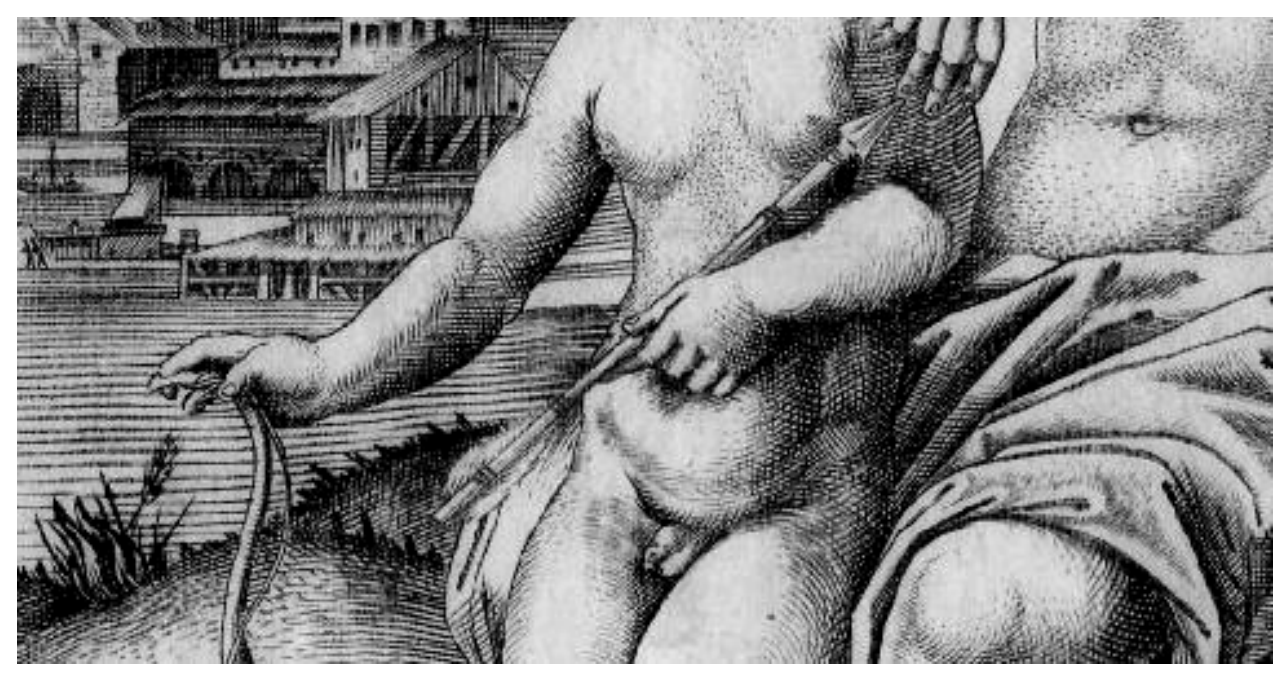

- Detalle del punteado y del uso de diferentes buriles.

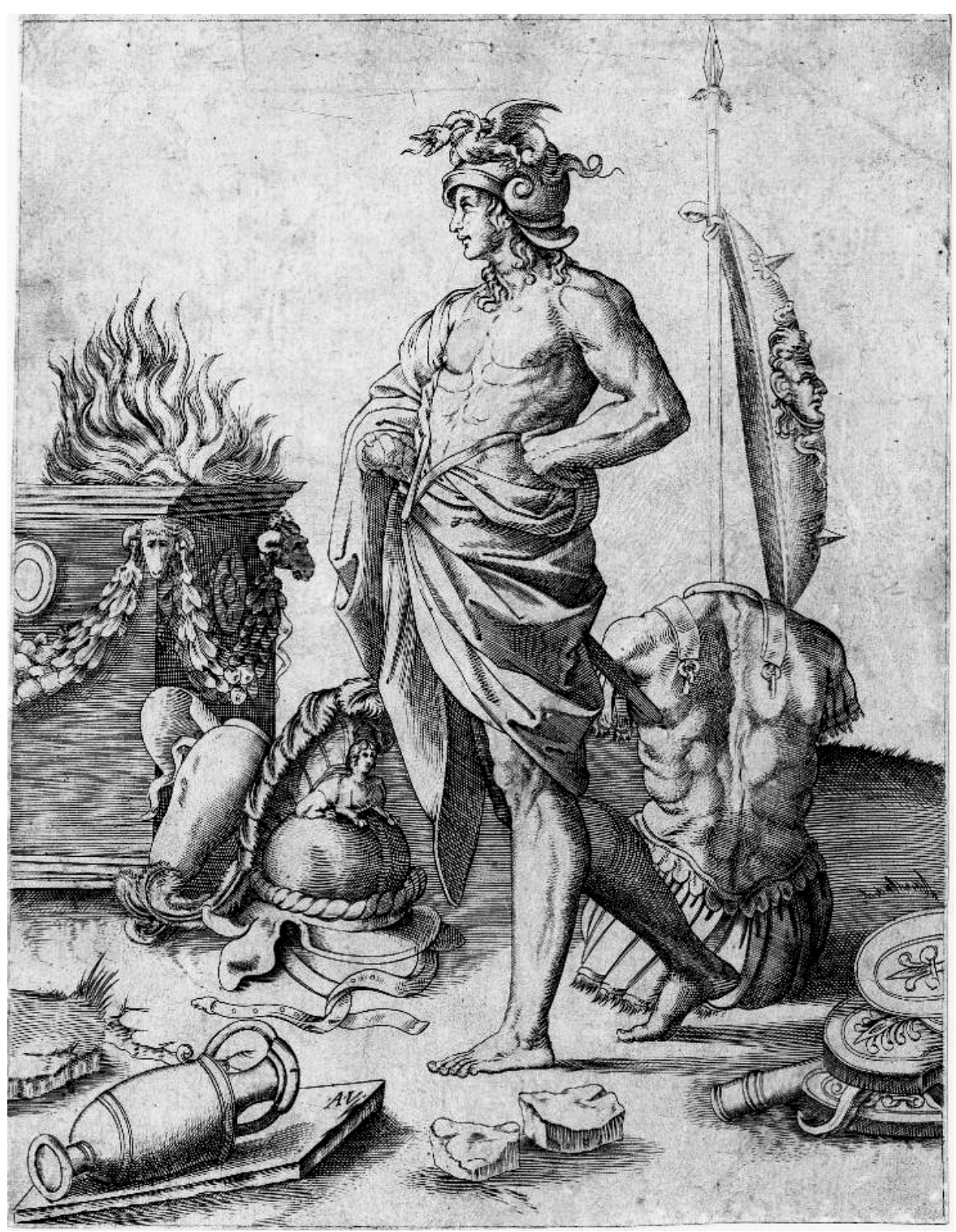

-Agostino Veneziano. Alcibíades. Buril. 1515-30. 

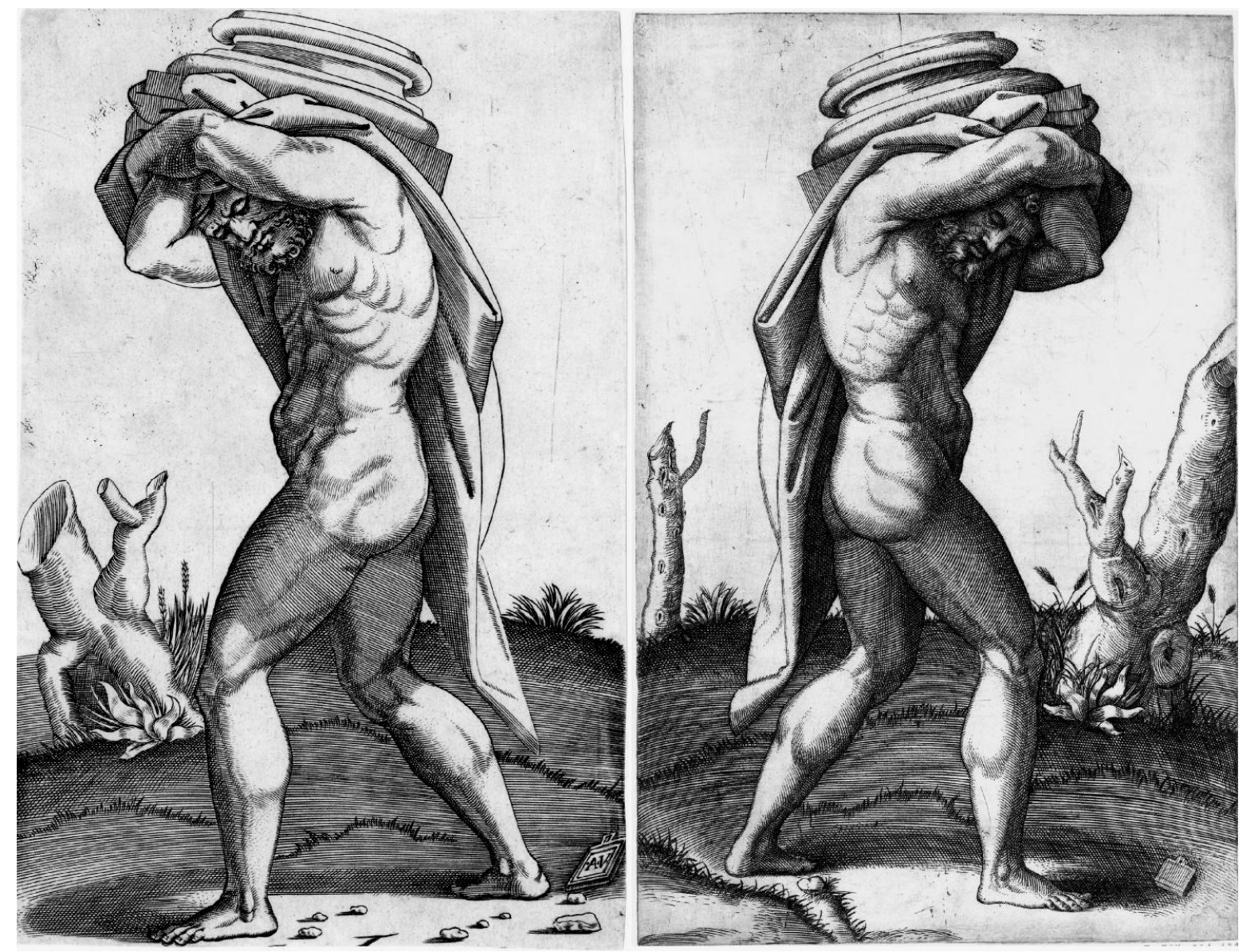

- Agostino Veneziano y Raimondi. Hombre transportando la base de una columna.1517-20.

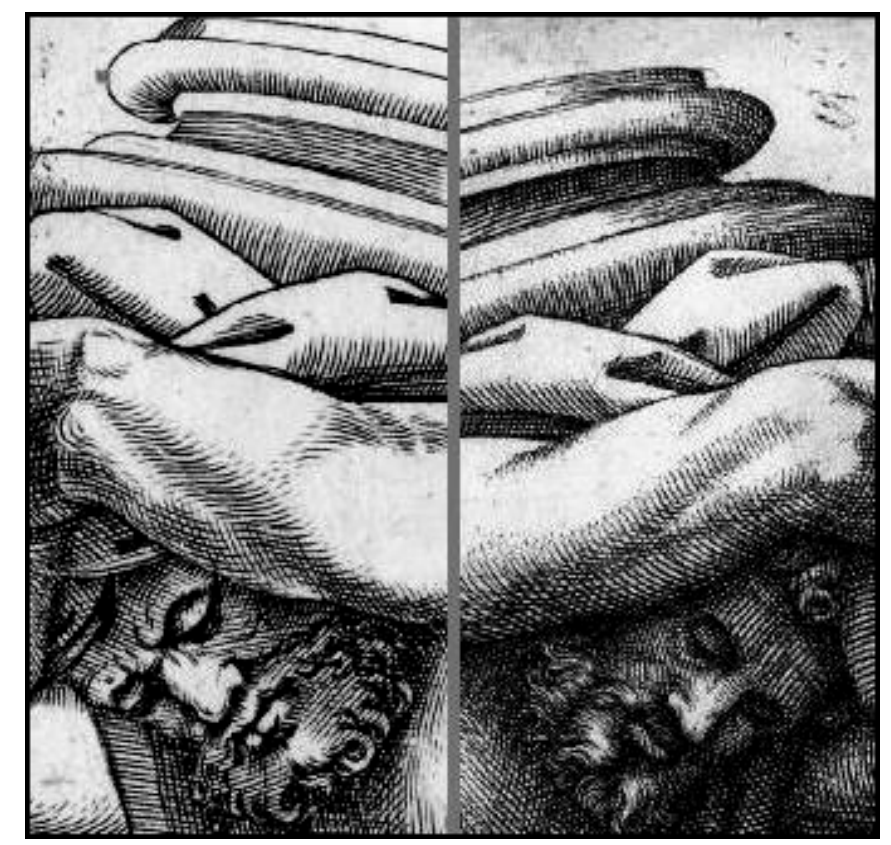

- Detalles de las cabezas y sus diferentes grafías. 


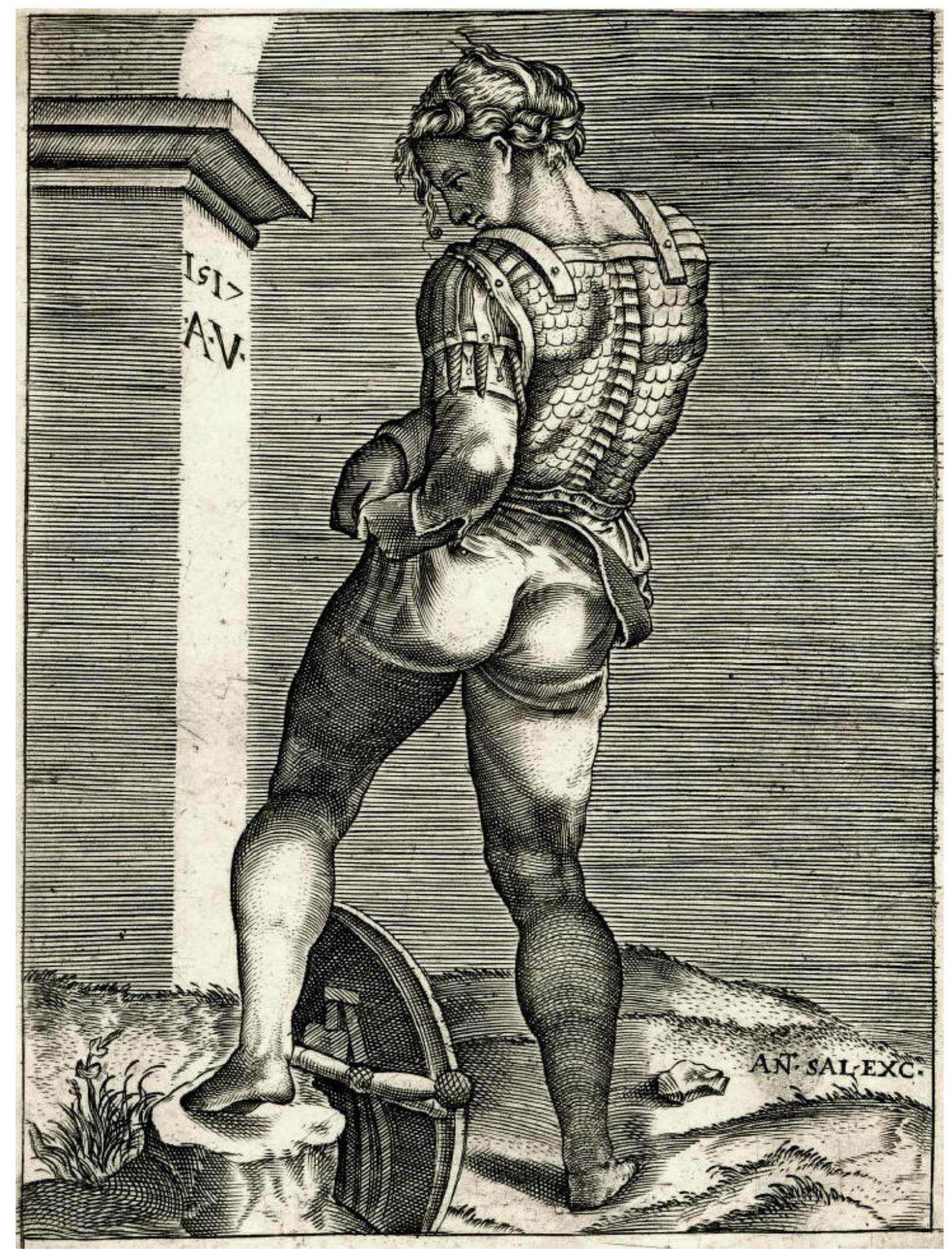

- Agostino Veneziano según Miguel Ángel. Guerrero Florentino. Buril. 1517.

Esta obra, basada en una figura del cartón creado para "La Batalla de Cascina", es una de las muchas que presenta la inscripción ANT.SAL.EXC. (Antonio Salamanca Imprimió). Uno de los canales de difusión de los trabajos de Marcantonio Raimondi y su equipo producidos durante estos años en Roma, pasaba por la empresa de este grabador, tipógrafo, librero y banquero de origen español, instalado en la ciudad e integrado en la vida social y artística romana desde 1511 hasta su muerte en 1562. 


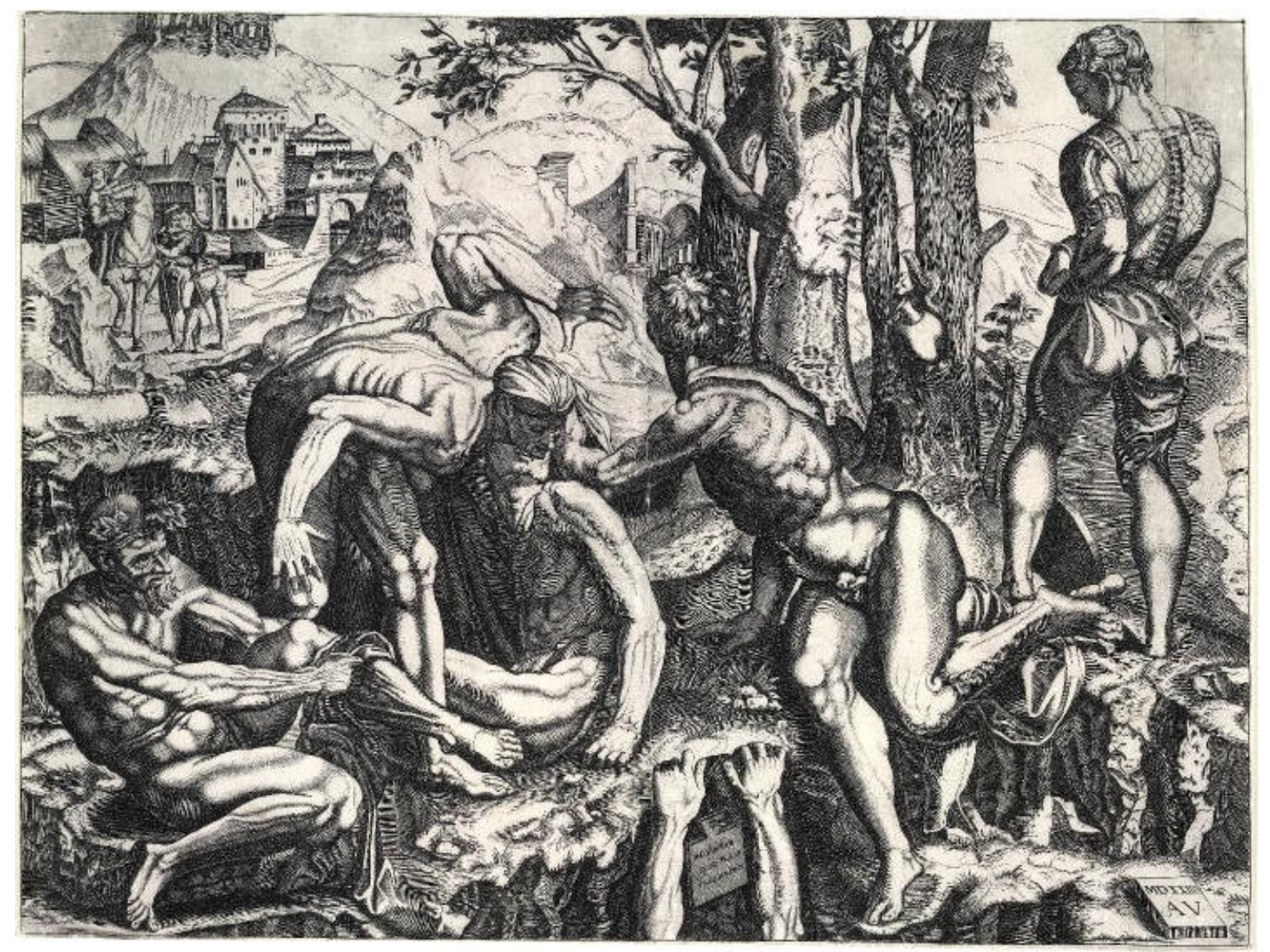

-Agostino Veneziano según "la Batalla de Cascina" de Miguel Ángel. 1524.

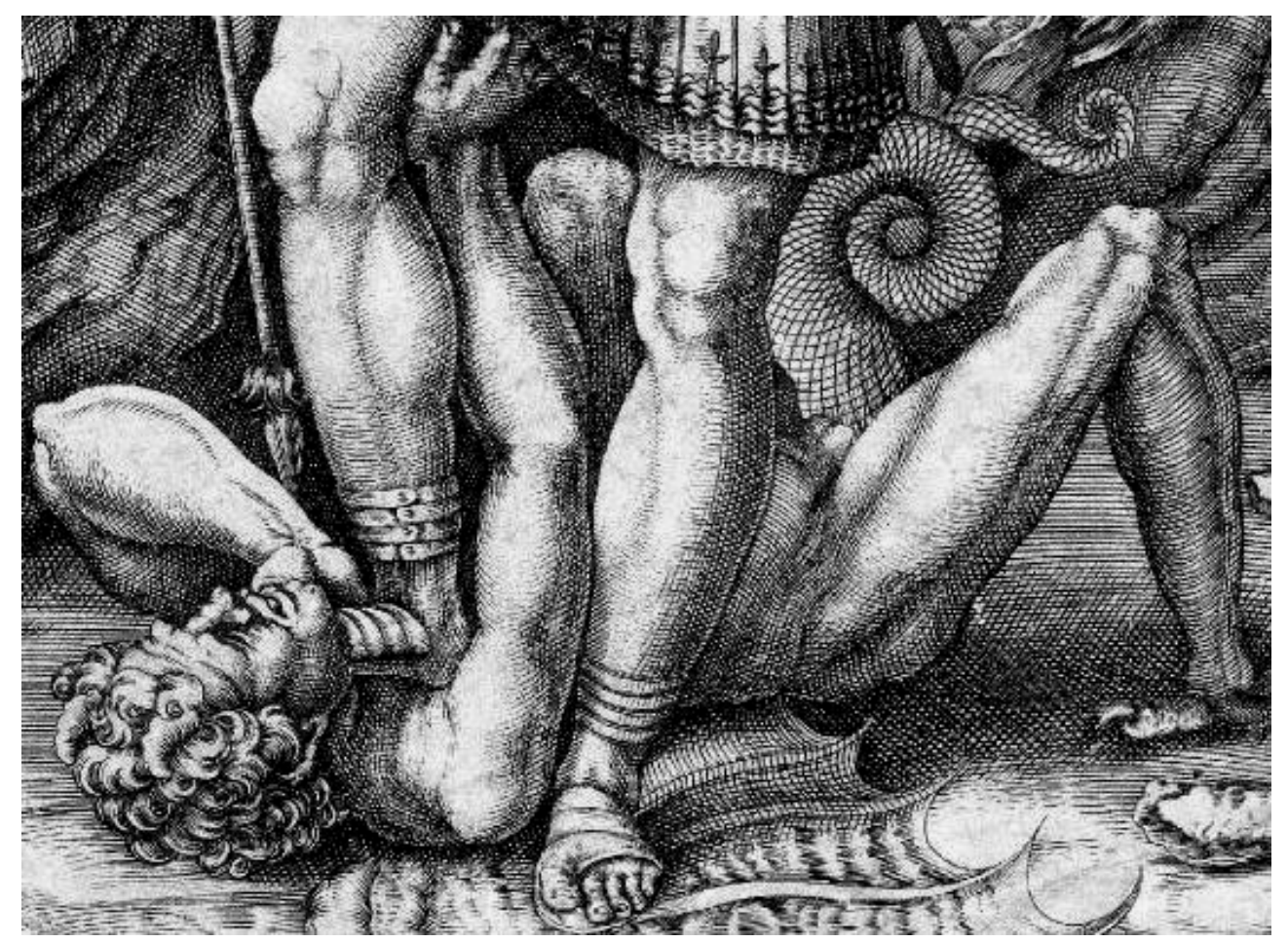

- Agostino Veneziano, detalle del Demonio vencido por San Miguel. 1515-28. 


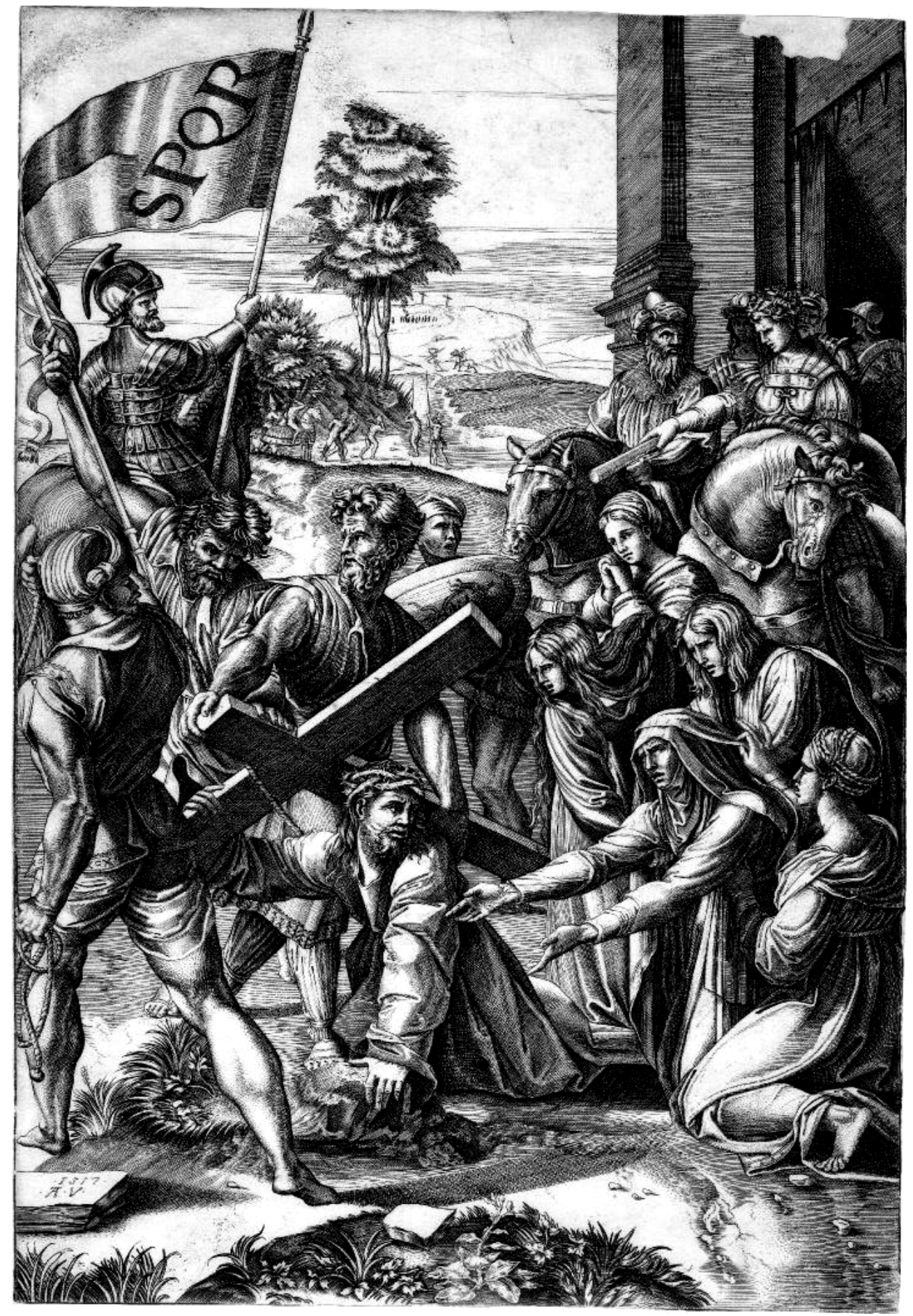

- Agostino Veneziano según Rafael. Cristo llevando la Cruz. 1517.

Obra según el lienzo de Rafael y sus colaboradores conocida como "Lo Spasimo de Sicilia", el encargo de realizar esta estampa es solo un año posterior a la entrada de Agostino al taller. El resultado, a pesar de la dureza formal debida al alto contraste de su luminosidad, alcanzó un gran éxito y fue reproducida por otros artistas y en otros medios. La monumentalidad conseguida, agrupa elementos de otras composiciones de Marcantonio ausentes del óleo original, cabezas y otros detalles que parecen producir una cierta descoordinación entre las figuras. 


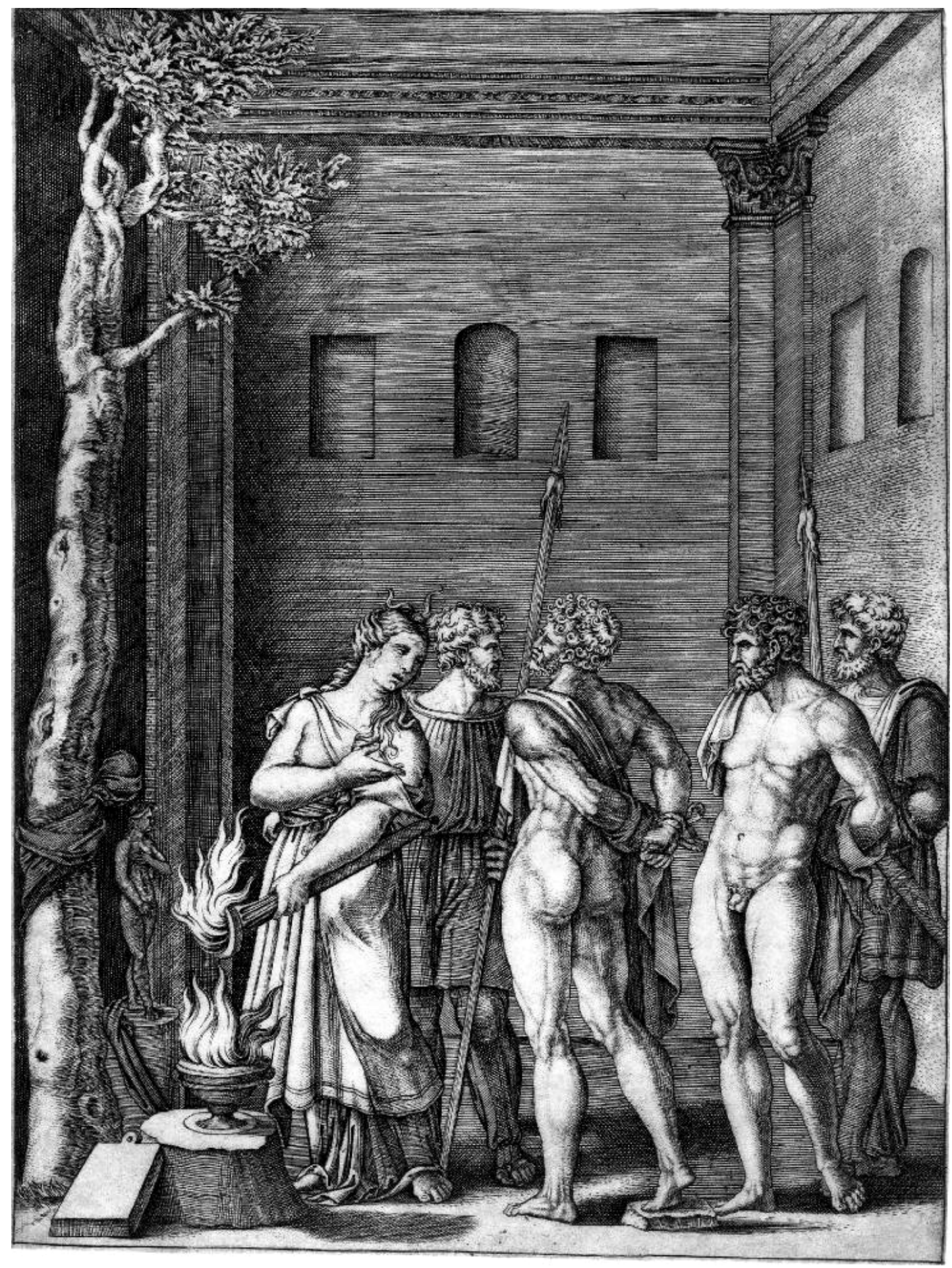

- Agostino Veneziano según Rafael. Ifigenia en el Templo de Diana. Buril. 1517-27.

Aquí, Agostino imita meticulosamente en el fondo arquitectónico la técnica de Raimondi mientras en las figuras sigue conservando sus propias características, especialmente la fuerte iluminación de los tres personajes del primer plano que por ese motivo se separan algo del resto de la composición. 


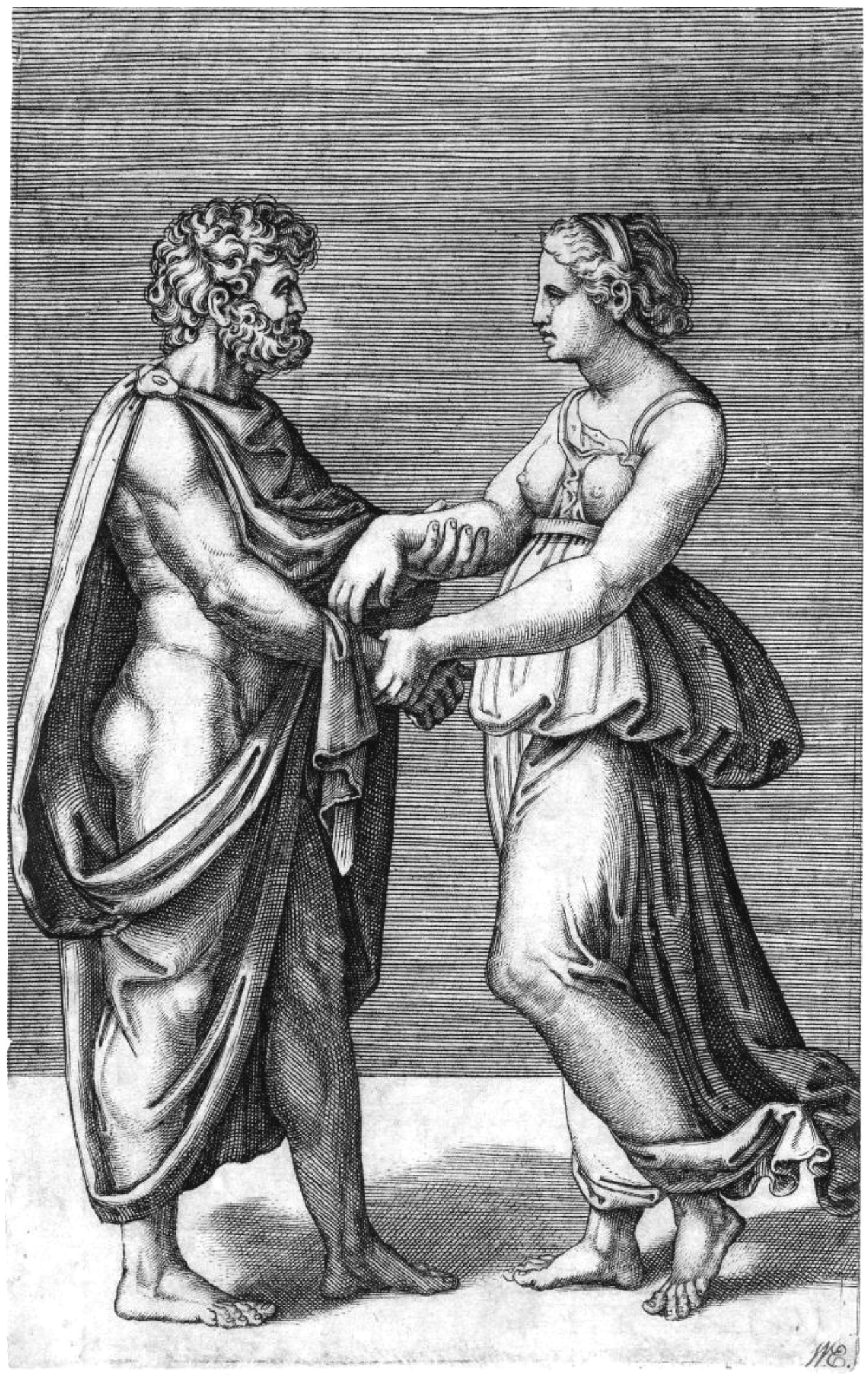

- Agostino Veneziano. Pareja tomándose de las manos. 1520-30.

Obra de plenitud en la síntesis de estilos de Raimondi y Agostino Veneziano, pertenece a lo más significativo del trabajo común del equipo que se disolvería tras la 
catástrofe del año 27. La diáspora artística que le siguió, horrible en lo humano, cooperaría decisivamente a la difusión del modo de hacer romano por toda Italia y Europa.

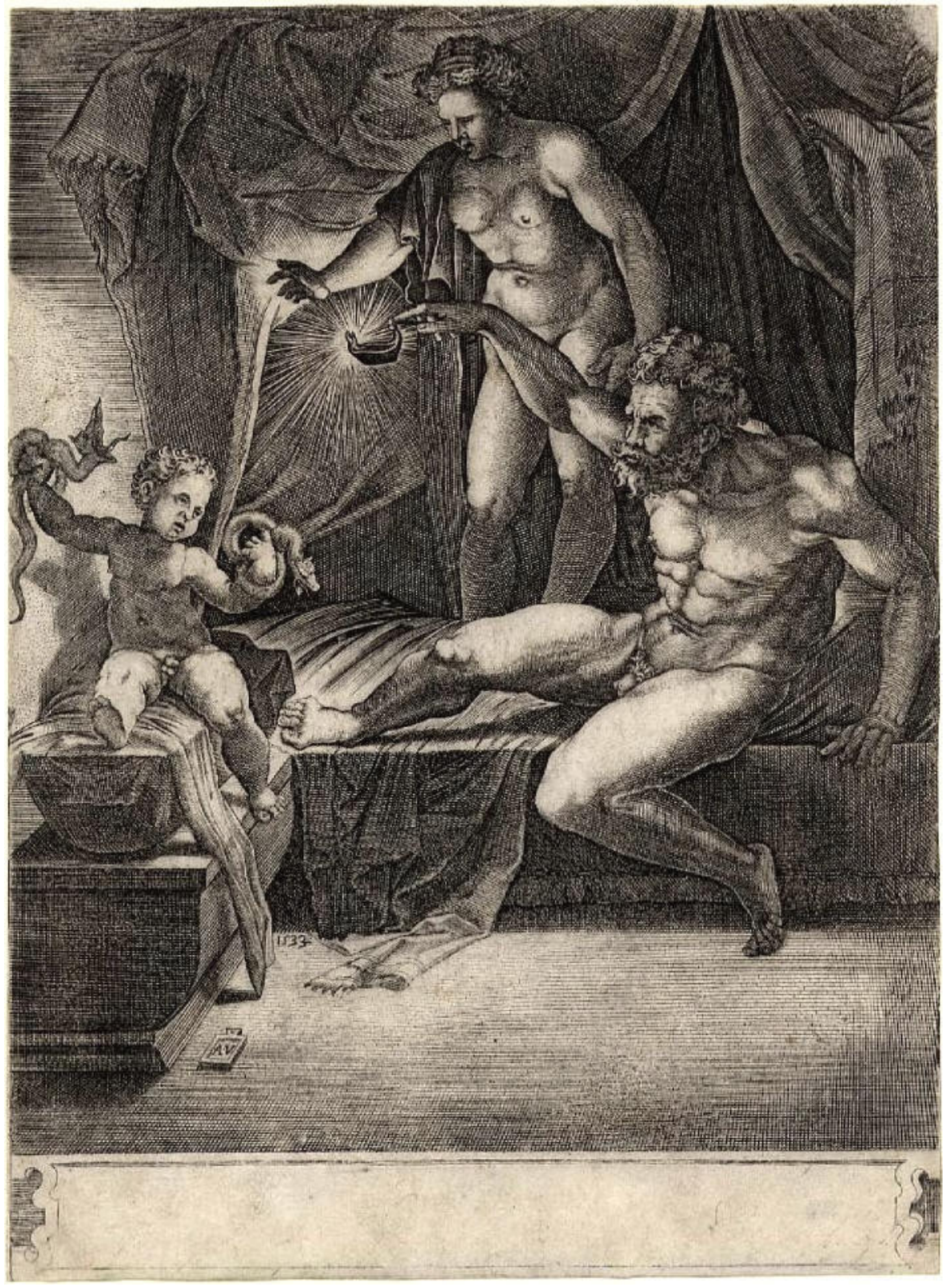

-Agostino Veneziano. Hércules niño en la cuna mata a dos serpientes siendo observado por Anfitrión y Alcmena. Buril. 1533. 


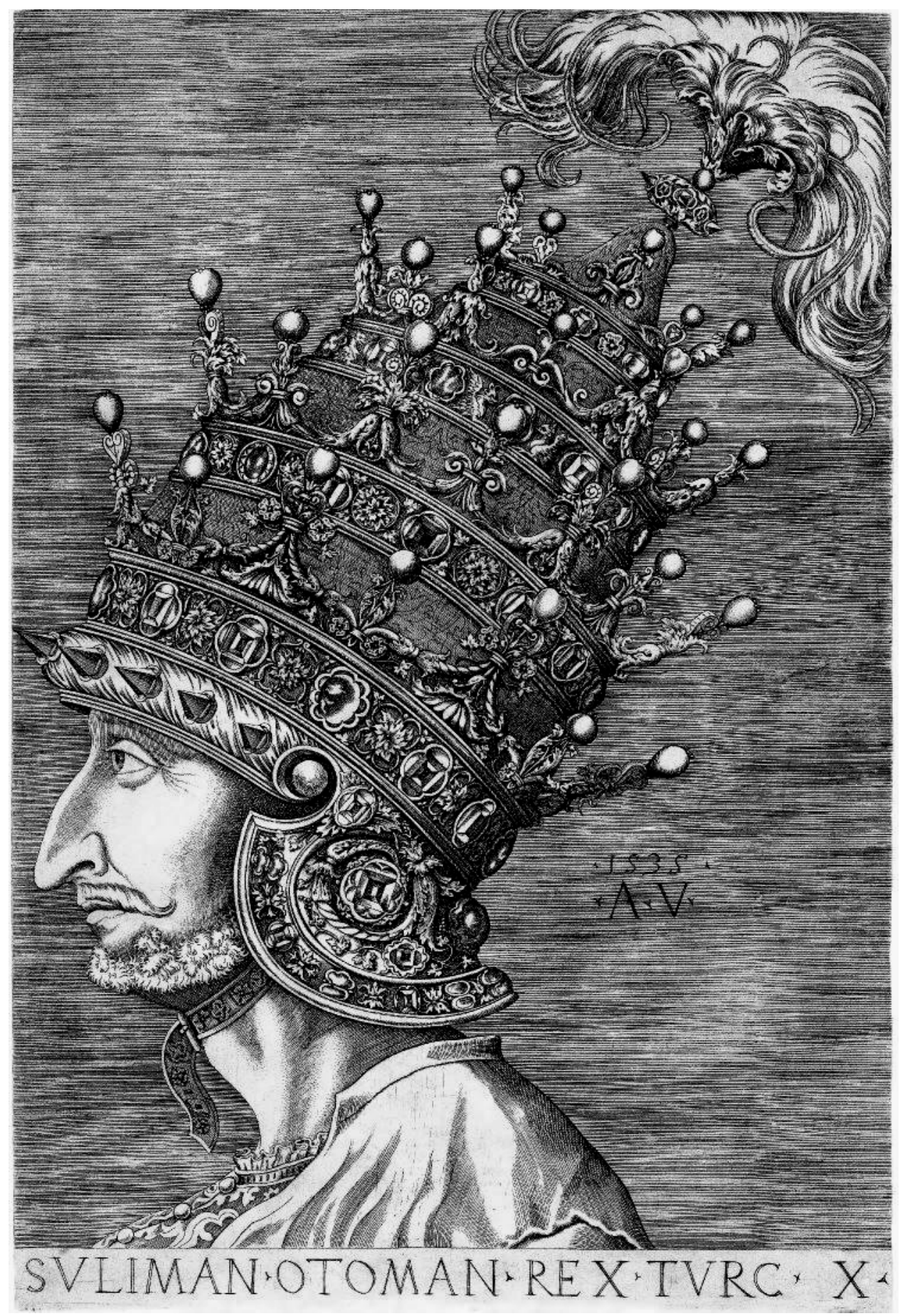

-Agostino Veneziano. Solimán el Magnífico. Buril 1535. 
Antonio de Salamanca (1478-1562), cuyo apellido familiar era Martínez, es citado con frecuencia como librero milanés erróneamente quizás por la fuerte presencia española en el Ducado de Milán y la coincidencia de tan común apellido entre los residentes españoles en este lugar. Oriundo de la ciudad de Salamanca puede que llegara a Roma en el sequito de un alto clérigo de la casa de Alba sobre el año 1511 y que sus dotes artísticas le sirvieran para entrar en contacto prontamente con el círculo de Rafael y de Raimondi.

En 1527 ya aparece empadronado como librero en la Parroquia de San Lorenzo en Damaso, donde sería enterrado bajo una losa sepulcral que nos aclara su lugar y fechas de nacimiento y defunción. Su librería e imprenta estaba situada en el Campo dei Fiori y sabemos que se romanizó completamente. Casó con una dama de familia adinerada, Sigismunda Vicardi y en el año 1546 fue admitido como miembro de la "Academia dei Virthuosi ad Panteón", ocasión en la que vuelve a cambiar su nombre por Marco Antonio de Salamanca, quizás como homenaje a Marcantonio Raimondi. En la documentación de este nombramiento aparece definido como "banchiere", por lo que podemos suponer que también se dedicara a conceder pequeños préstamos.

Como grabador poco sabemos de su obra, pero como editor tanto de libros como de grabados, nos constan sus ediciones literarias de libros españoles, La Celestina, el Amadís o las obras de Garcilaso y sus impresiones de las planchas de Raimondi, da Ravenna o Veneziano y un gran número de colaboradores y seguidores de esta escuela.

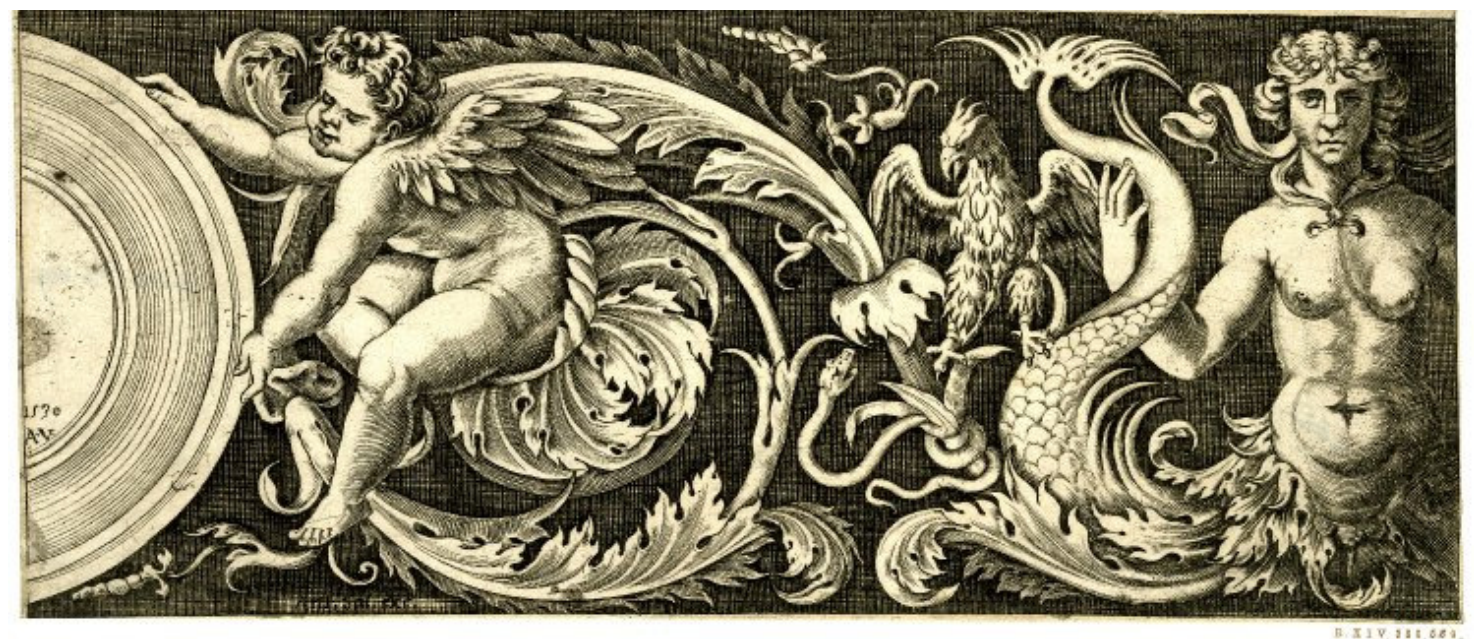

-Agostino Veneziano para Antonio Salamanca. Friso decorativo. Buril. 1530.

Su negocio de edición de estampas se incrementó notablemente tras el desastre del 27, del que sabemos que Salamanca no salió perjudicado ya que el año 28 pudo permitirse pagar una alta dote por el matrimonio de su hija. Es aventurado especular con que el dinero que Marcantonio tuvo que reunir para pagar el rescate que le permitiría escapar de Roma, saliera en parte de la adquisición por parte de Salamanca de las planchas y dibujos de Rafael que aquel poseía, pero entra dentro de lo posible. 
Edita todo tipo de imágenes, reproducciones de la obra de pintores famosos, santorales, colecciones de caballeros romanos y césares, paneles decorativos clásicos o interpretaciones de las esculturas recién rescatadas del olvido en excavaciones promovidas por la nobleza o el Papado y atesoradas en sus colecciones.

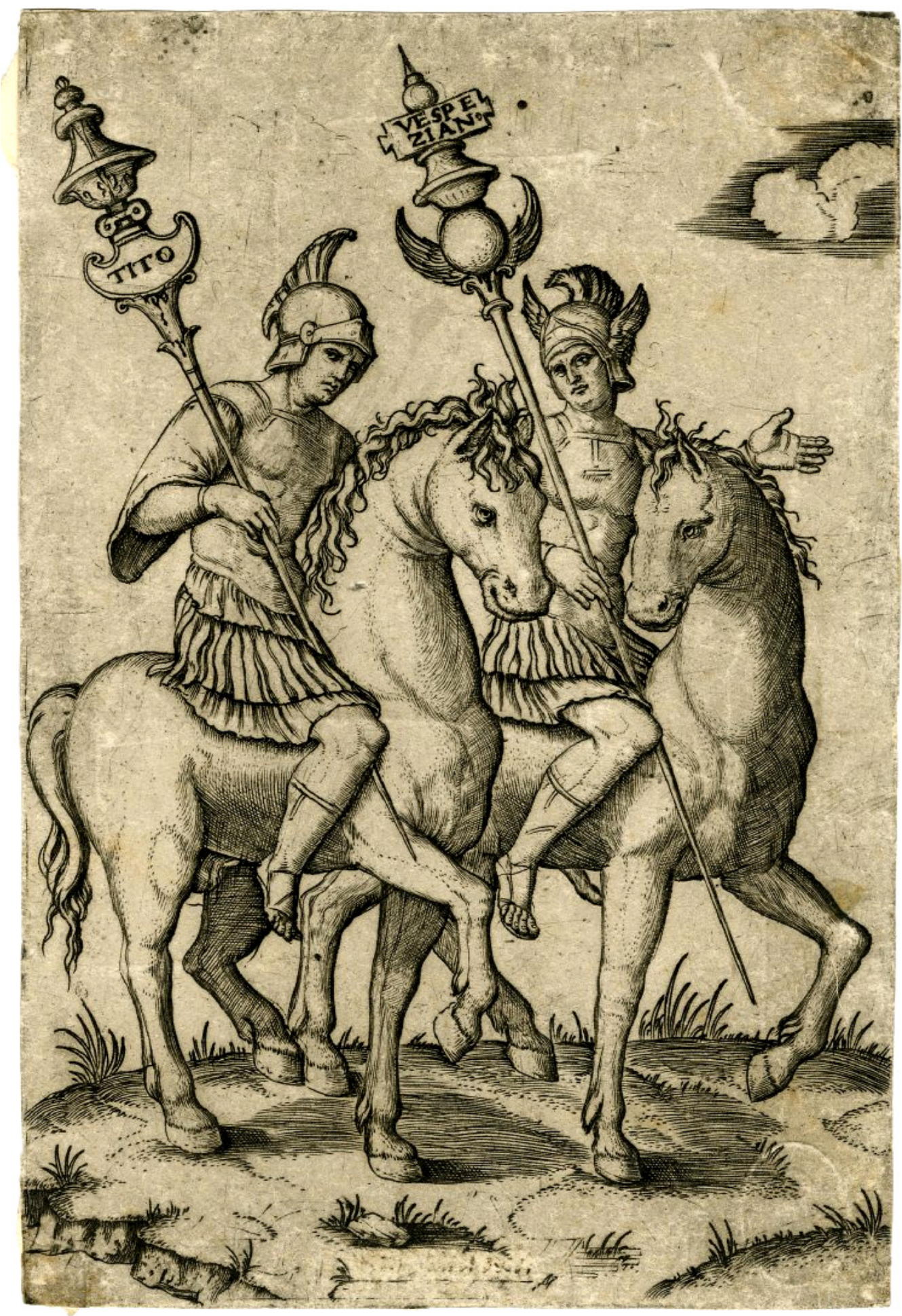

- Marcantonio Raimondi para Antonio Salamanca. Vespasiano y Tito. 1511-27. 


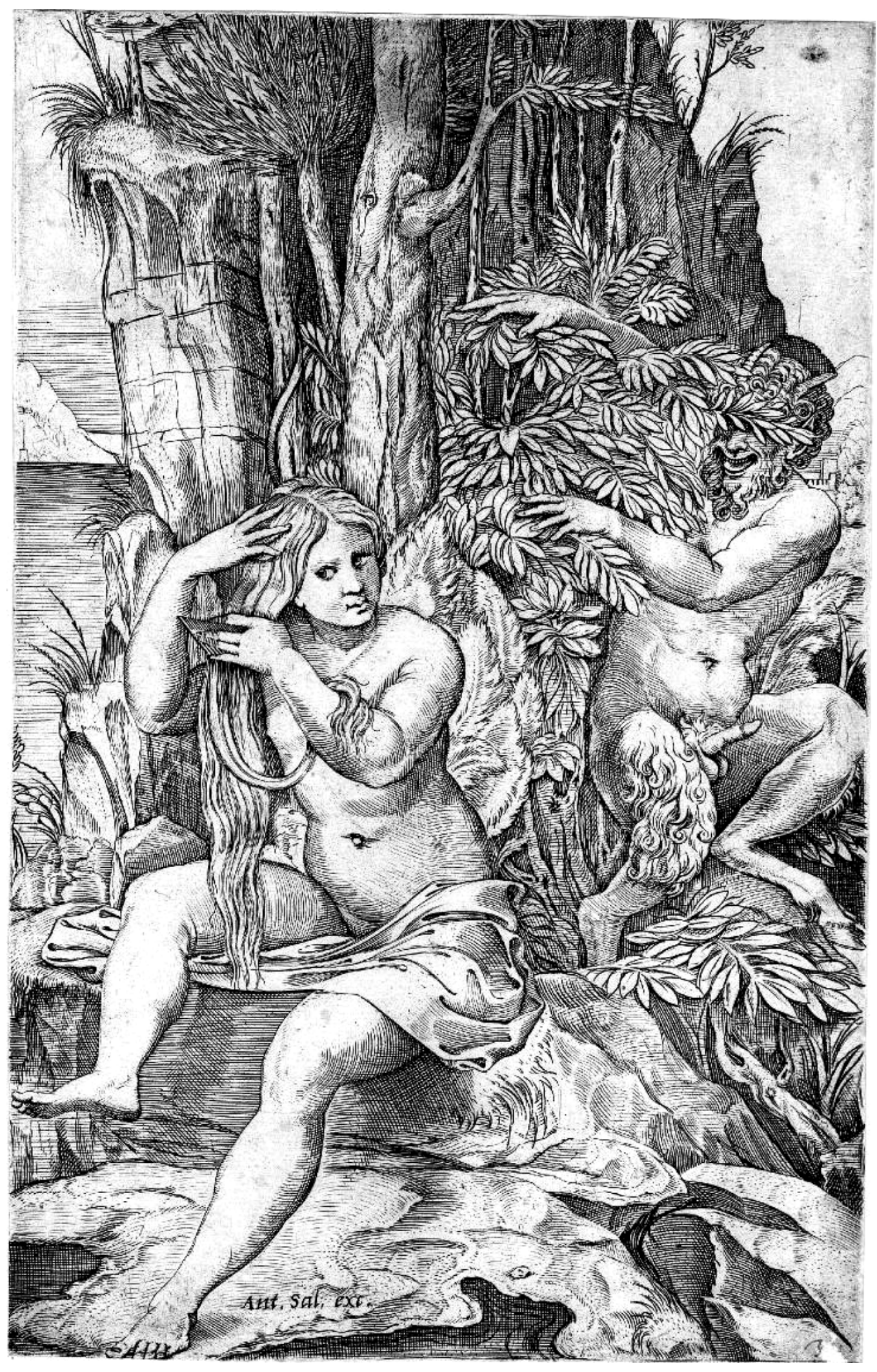

- Marco da Ravenna para Antonio Salamanca. Syrinx y Pan. Buril. 1516. Edición probablemente posterior en muchos años a la fecha de ejecución. 


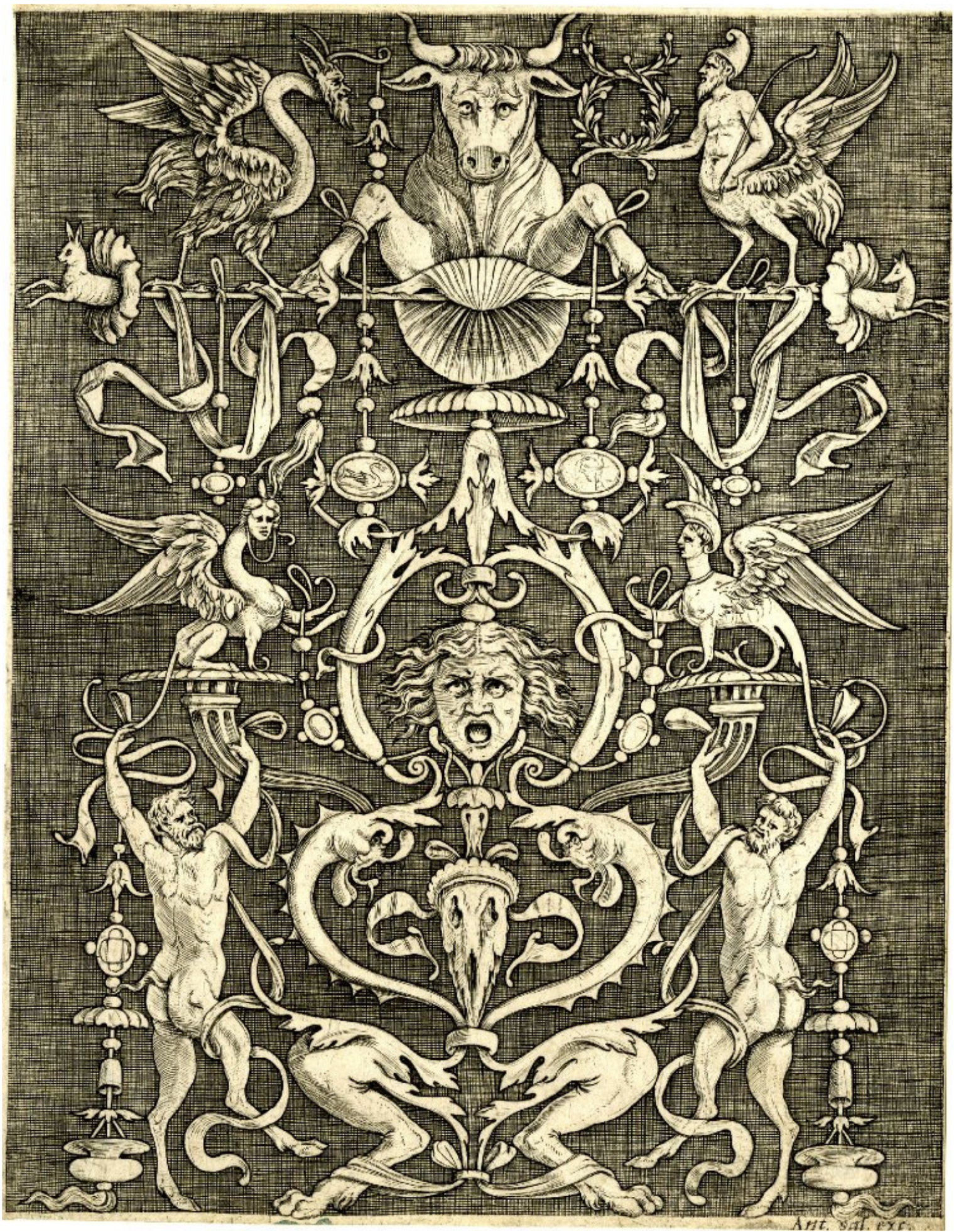

-Agostino Veneziano para Antonio Salamanca. Panel decorativo. Buril. 1530. 


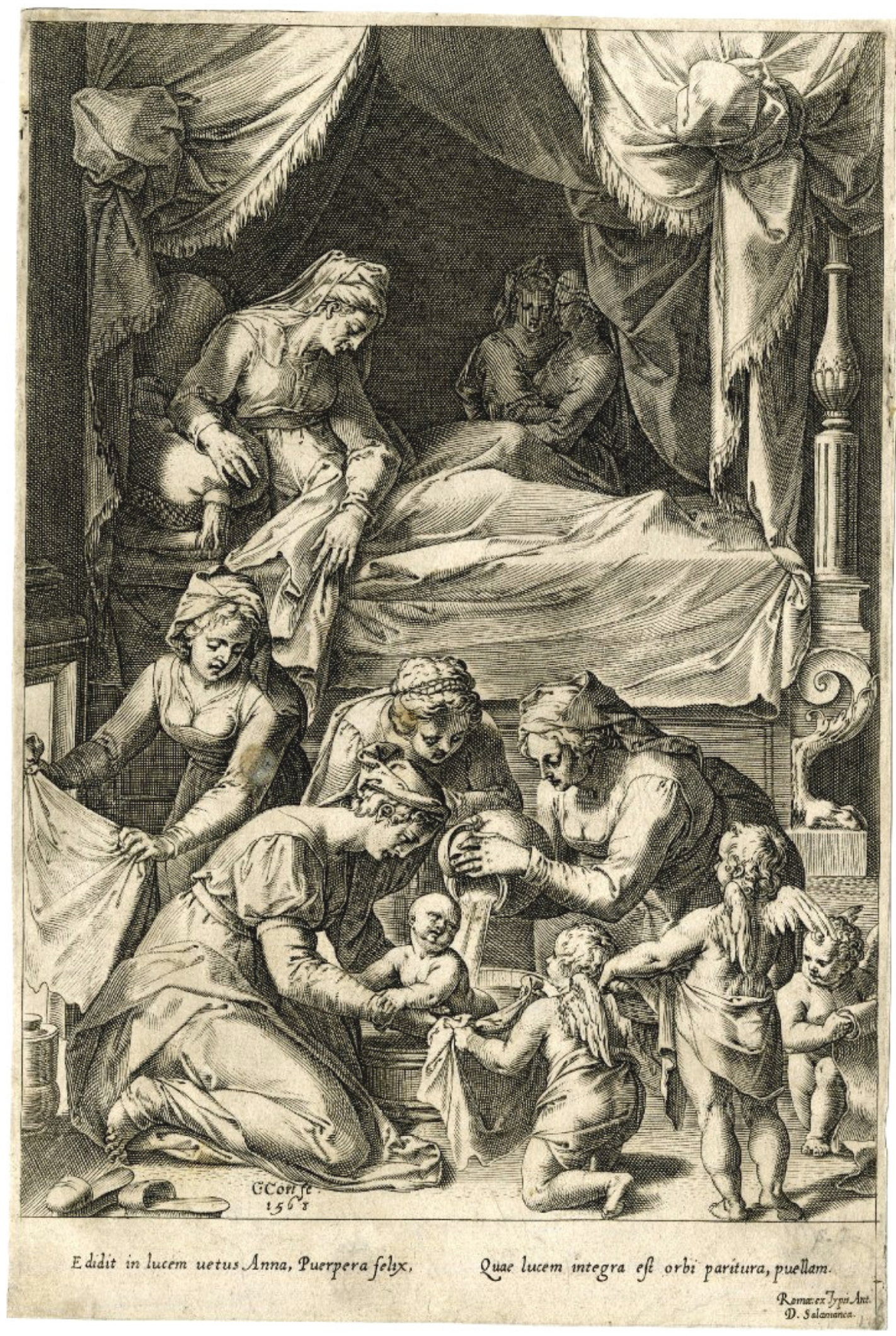

- Cornelis Cort para Antonio Salamanca. Nacimiento de la Virgen. Buril. 1560. 


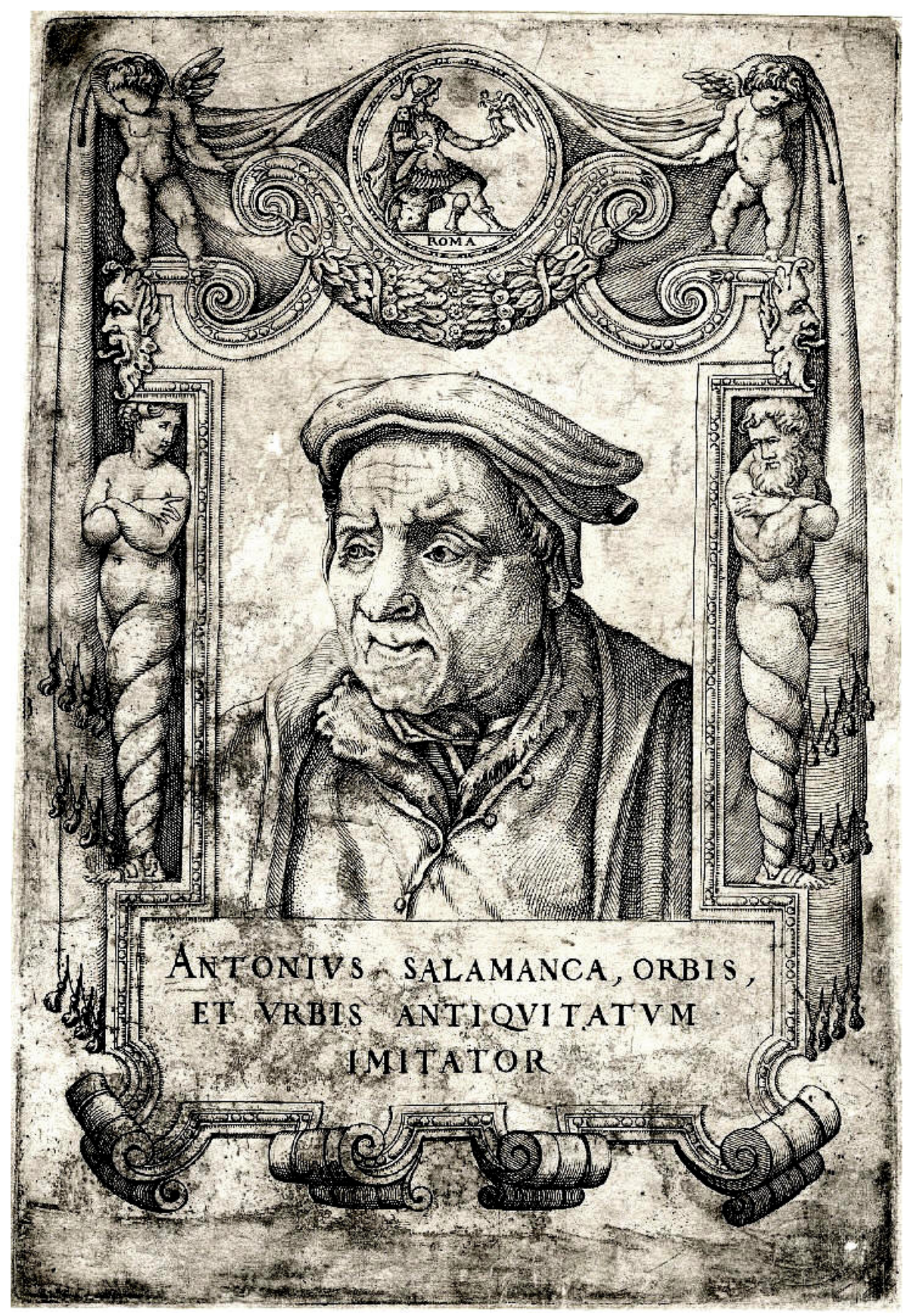

-Nicolás Beutrizet. Retrato de Antonio Salamanca. Buril. 1540-60.

Vemos así que la primera codificación sistemática para representar con verosimilitud el claroscuro y los volúmenes, desarrollada por Marcantonio Raimondi y sus seguidores, pasa al resto del mundo a través del negocio de editores y mercaderes que verían en el ansia de conocimiento que por los logros del Renacimiento se desarrolló en toda Europa, la posibilidad de hacer un buen negocio.

Otros artistas grabadores, como Jacopo Caraglio, el Maestro del Dado, Bonasone o Beutrizet, alumnos directos de Raimondi o miembros de la siguiente generación, adoptarían su forma de hacer las cosas y en persona propia o a través de sus obras la extenderían definitivamente. 


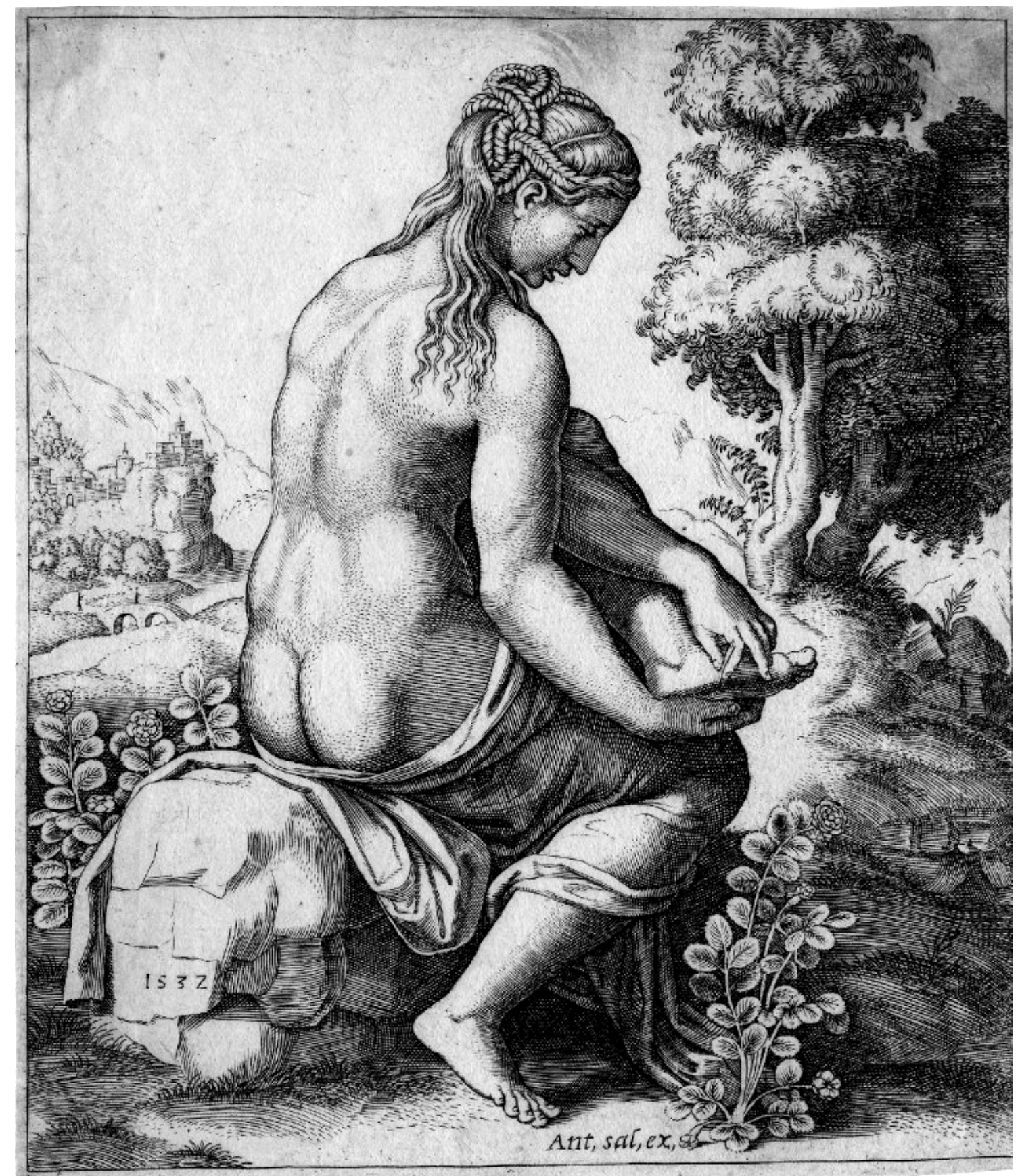

-Maestro del Dado. Venus herida por la espina de una Rosa. Buril. 1532.

Trabajo ejecutado también para la editora de estampas de Antonio Salamanca por el Maestro del Dado. Llamado así por su costumbre de firmar sus estampas con un pequeño cubo con la letra $B$ en una cara, uno de sus trabajos señalados es una serie sobre la historia de Amor y Psique en la que colaboró con Agostino Veneziano. 


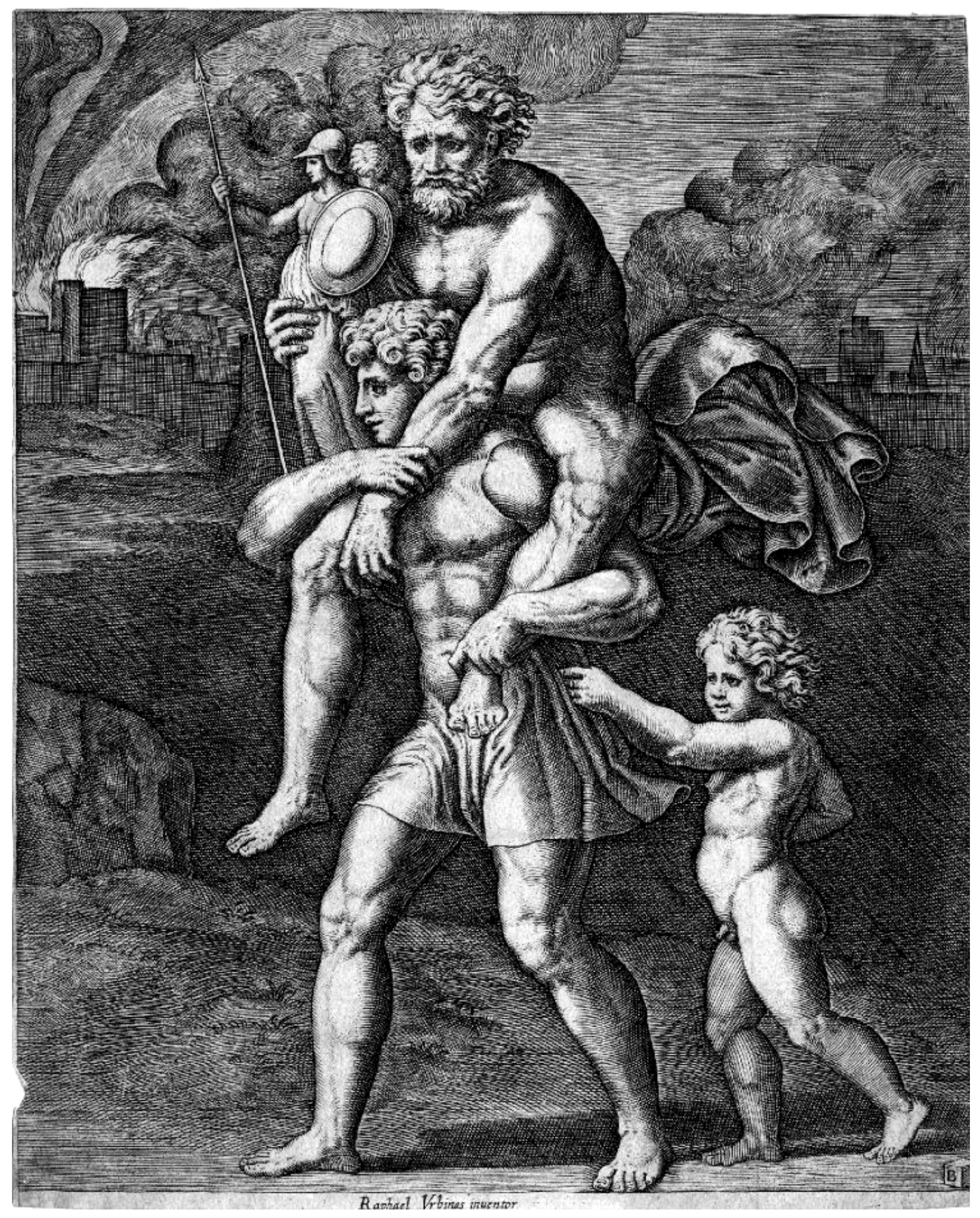

-Maestro del Dado. Eneas y Anquises. Buril. 1530-60 


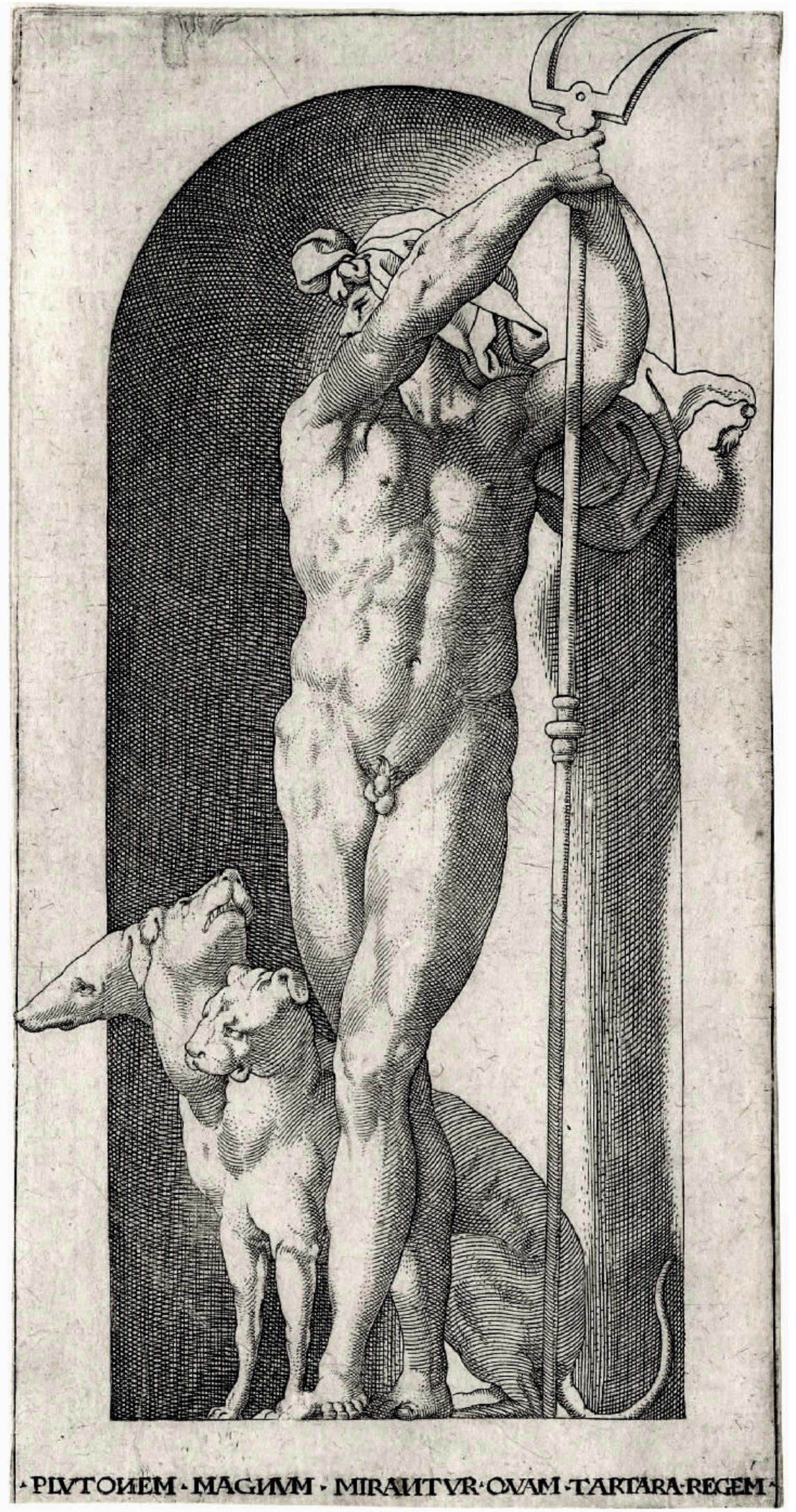

-Jacopo Caraglio. Plutón y Cancerbero. Buril. 1526. 


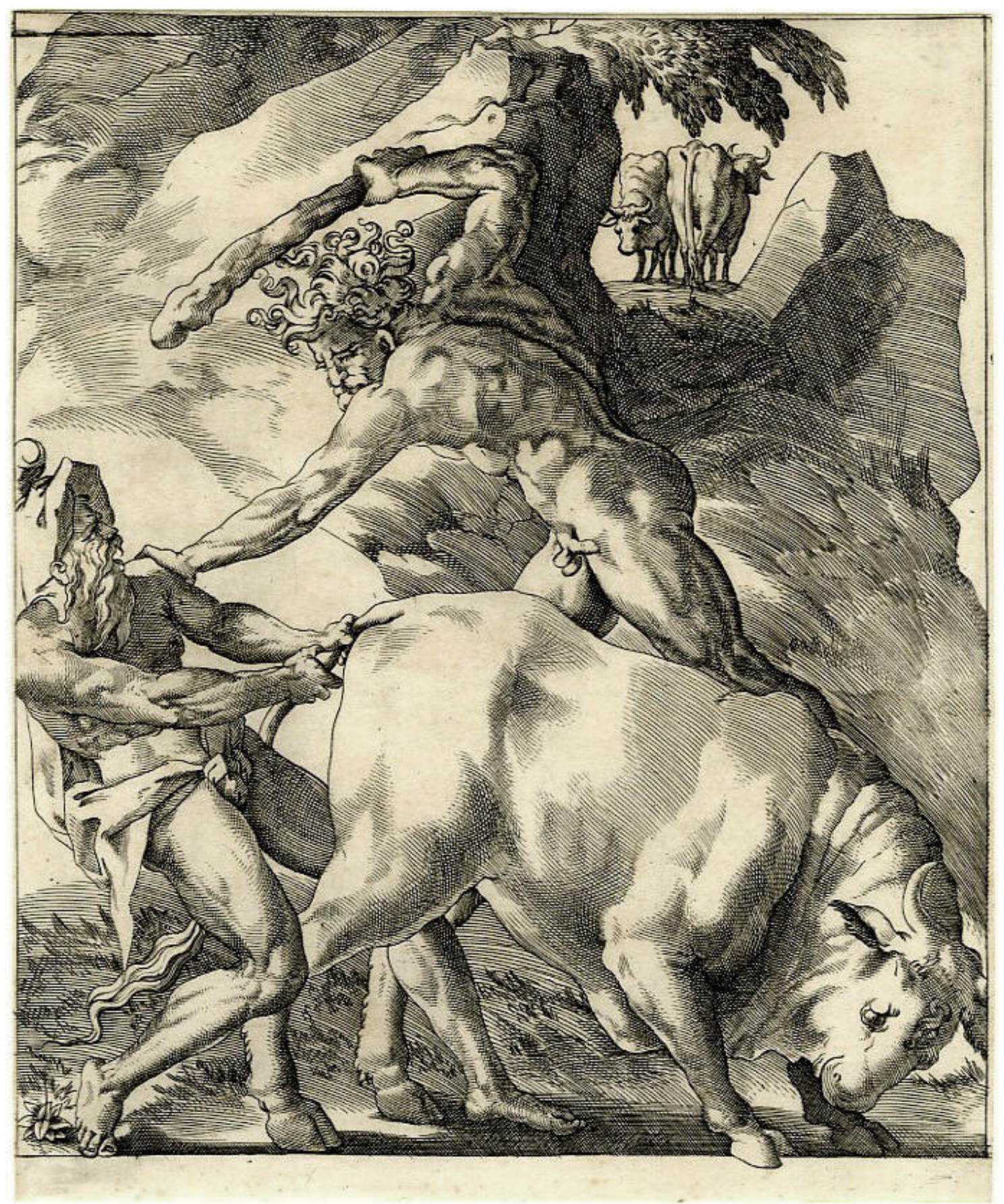

- Jacopo Caraglio según Rosso Florentino. Los Trabajos de Hércules, Hércules y Caco. Buril. 1526-39. 


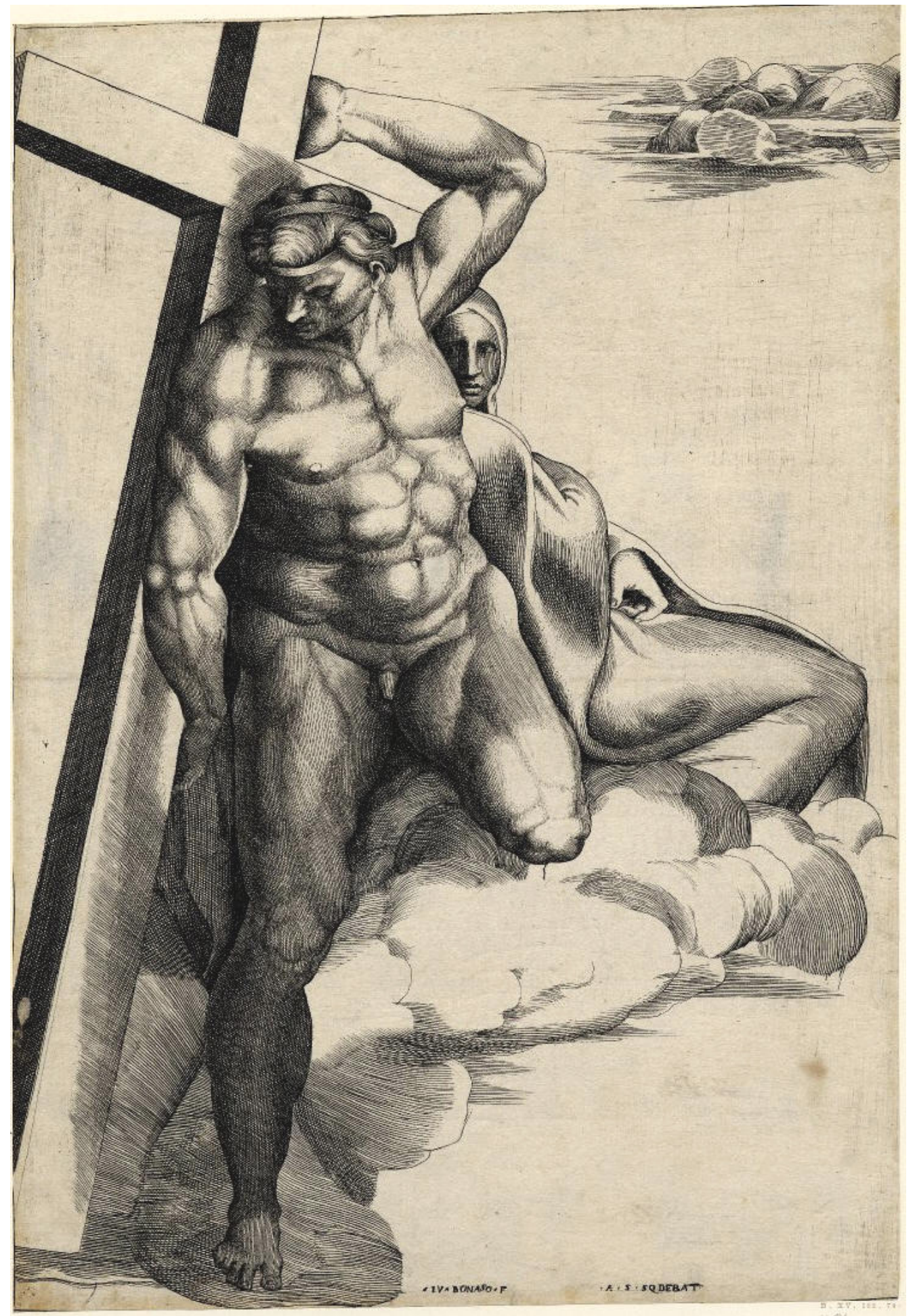

- Giulio Bonasone según Miguel Ángel. Cristo con la Cruz a cuestas. Buril. 1531-50. 
El proyecto empresarial y artístico de Marcantonio Raimondi, termina abruptamente con el asedio y saqueo de la Roma de Clemente VII, aliado de Francia, por las Tropas Imperiales de Carlos V. La ciudad sufrió terribles consecuencias de todo tipo y Marcantonio tuvo que pagar un alto precio para escapar de la ocupación. No se sabe con certeza que fue de las planchas grabadas en esos tres lustros de trabajo, Vasari habla de que el Baviera las poseía después de 1527, además existe la posibilidad de que hubieran pasado a la empresa de Antonio Salamanca.

Marcantonio abandonó Roma arruinado camino de Bolonia donde moriría. Testimonios literarios le citan en tiempo pasado a mediados de la década de los 30, por lo que se da como fecha de su desaparición el año 1534. Ninguna plancha de su autoría está fiablemente datada después de 1527.

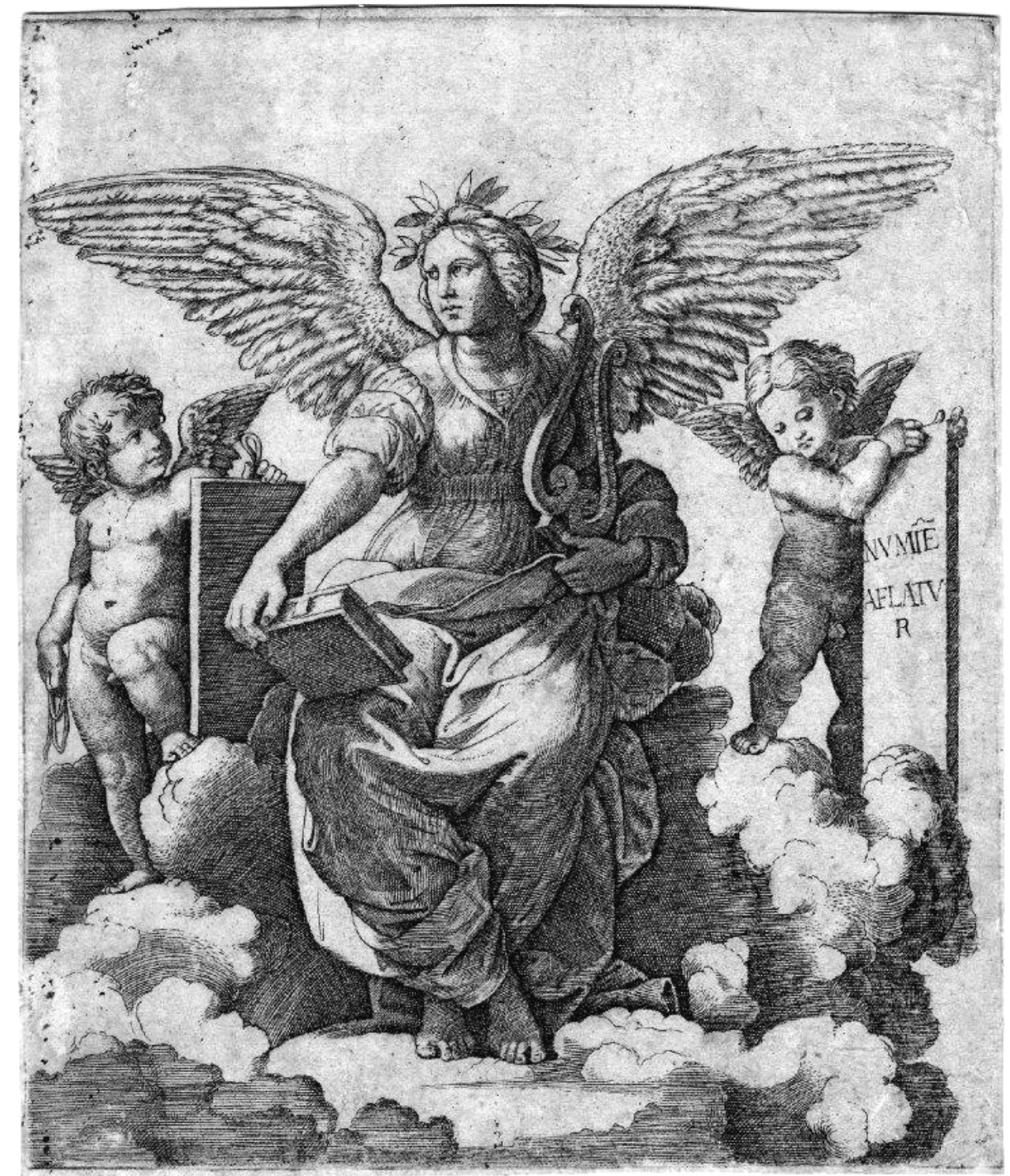

-Marcantonio Raimondi según Rafael. La Poesía. Buril.1515-20. 


\section{-Biblografía específica: Marcantonio Raimondi.}

ARCHER, Madeline Cirillo. Italian masters of the sixteenth century. Abaris Books. Nueva York, 1995

ARGAN, Giulio Carlo. Renacimiento y Barroco: El arte italiano de Miguel Ángel a Tiepolo. Akal. Madrid, 1999

BARTSCH, Adam von. OBERHUBER, Konrad (editor). The works of Marcantonio Raimondi and of his school. Abaris Books. Nueva York, 1978

CUNDALL Joseph. The Great Works of Raphael Sanzio of Urbino; A Series of Thirty Photographs from the Best Engravings of His Most Celebrated Paintings. Nabu Press. Charleston, 2010

DEAN, Clay. PON, Lisa, FAIRBANKS, Theresa. Changing impressions : Marcantonio Raimondi \& sixteenth century print connoisseurship. Yale University Art Gallery. New Haven, 1999

GIGLIOLI, D.H. Nota su Marcantonio Raimondi e Jacopo Francia. Editoriale Umbra SAS. Foligno, 1934

GONZALO SÁNCHEZ-MOLERO, José Luis. Antonio de Salamanca y los libros españoles en la Roma del siglo XVI. Actas del Congreso Internacional celebrado en la Academia de España en Roma: Roma y España, un crisol de la cultura europea en la Edad Moderna. 2 vols., I, pp. 335-366. Seacex. Madrid, 2007 http://www.seacex.es/Spanish/Publicaciones/CONGRESO ROMA Y ESPA\%C3\%91A V OL\%20I/Antonio\%20de\%20Salamanca.pdf

GRAFTON, Carol Belanguer. Great woodcuts of Albrecht Durer. Dover Publications Inc. Mineola, Nueva York, 2004

IVINS, William M. Engravings by Four Renaissance Masters. Metropolitan Museum of Art Bulletin, New ser., v. 2, no. 10. Nueva York,(Junio, 1944)

http://www.metmuseum.org/publications/bulletins/1/pdf/3257099.pdf.bannered.pdf

LAWNER Lynne. I modi : the sixteen pleasures : an erotic album of the Italian Renaissance : Giulio Romano, Marcantonio Raimondi, Pietro Aretino, and Count Jean-Frédéric-Maximilien de Waldeck. Peter Owen. Londres, 1988

PON, Lisa. Raphael, Dürer, and Marcantonio Raimondi copying and the Italian Renaissance Print. Yale University Press. New Haven - Londres, 2004

SHOEMAKER, Innis H. The Engravings of Marcantonio Raimondi. The Spencer Museum of Art. Allen Press inc. Kansas, Lawrence, 1981

THOMPSON, Wendy. The Printed Image in the West: Engraving. En Heilbrunn Timeline of Art History. The Metropolitan Museum of Art, Nueva York, 2000 http://www.metmuseum.org/toah/hd/engr/hd engr.htm (Octubre,2003) 
VASARI, Giorgio. Las vidas de los más excelentes arquitectos, pintores y escultores italianos desde Cimabue a nuestros tiempos. Cátedra. Madrid, 2007

WITT, Antonio Antony de. Marcantonio Raimondi : incisión. La nuova Italia. Florencia, 1968 


\section{II-3: Una experiencia completa}

Varias circunstancias políticas, militares y artísticas confluyen en el segundo cuarto del siglo XV para influir decisivamente en la formación y desarrollo de un colectivo de grabadores reconocido como perteneciente a la Escuela de Fontainebleau.

En las luchas por la hegemonía europea, Roma perderá la partida con consecuencias nefastas en todos los campos. En el artístico, se producirá una diáspora de creadores allí activos en beneficio de otros centros italianos y europeos. Uno de los principales colaboradores de Rafael, Julio Romano, presente en Mantua poco antes del Saco de Roma, será el responsable de un proyecto arquitectónico y decorativo completo de gran influencia posterior, el Palacio de Té. Será este autor el que recomendaría al rey de Francia un colectivo de manieristas italianos, encabezado por Rosso Fiorentino, Francesco Primaticcio y Luca Penni, para acometer un proyecto de gran trascendencia.

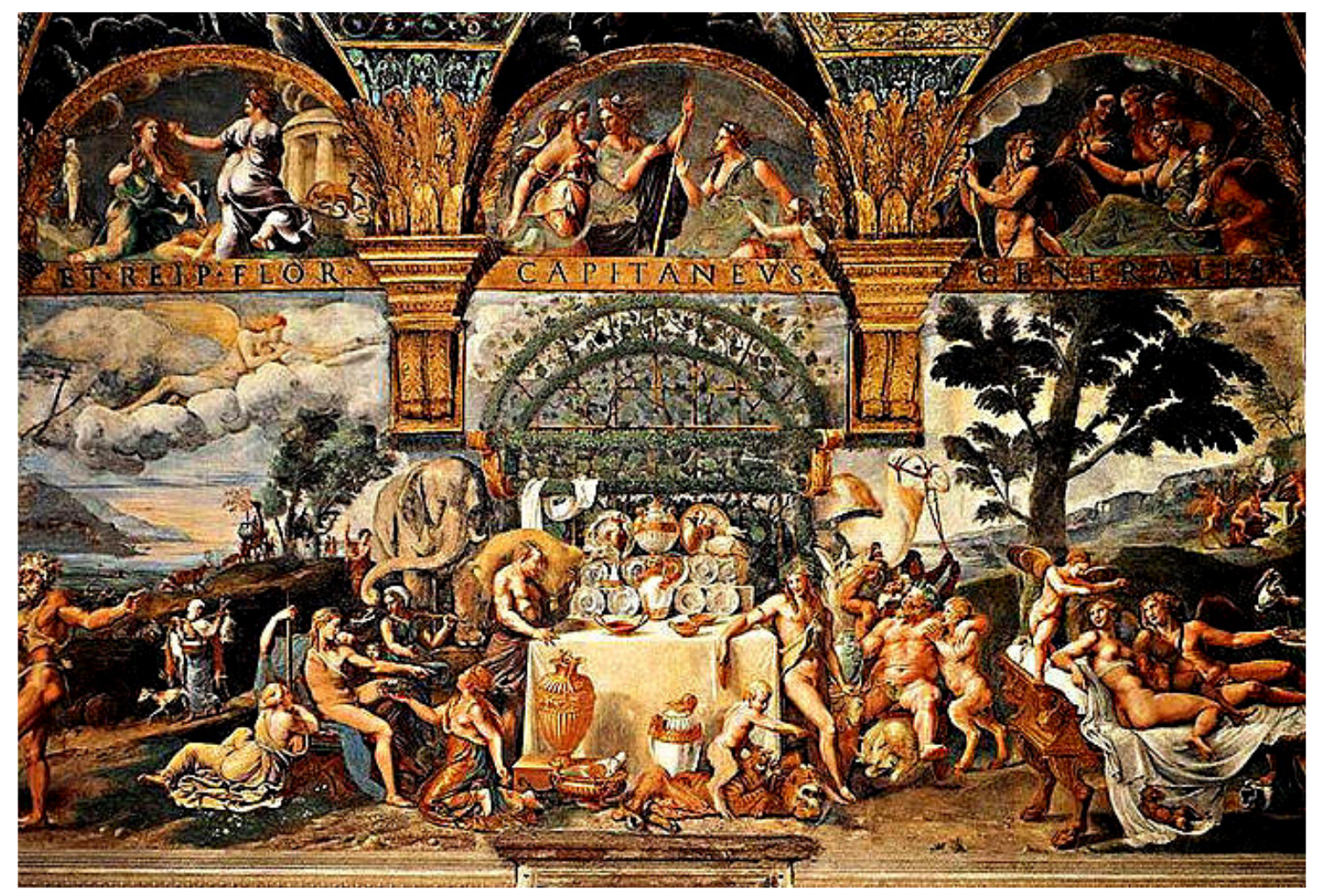

- Julio Romano, Palacio del Té. Banquete de Amor y Psyche. Frescos . 1525-35.

En Francia, la política cultural del rey Francisco I le reportará en la posteridad reconocimiento como defensor del saber, las artes y las letras. Coleccionista y mecenas de autores italianos de primer orden como Cellini, Miguel Ángel y Leonardo da Vinci, será el responsable de la formación de un grupo internacional de creadores de todas las disciplinas artísticas en los trabajos del conjunto palaciego de Fontainebleau.

Un hermano de Penni al igual que Julio Romano, había formado parte del círculo de Rafael, por lo que el conocimiento de los logros en el campo del grabado alcanzados por Marcantonio Raimondi se trasladará a Fontainebleau con los responsables artísticos del proyecto. 
Estos artistas italianos, además de su propia obra también trasladan a Francia la influencia de otros colegas, como Corregio o Parmigianino que tendrían gran importancia en la gestación de las características de la Escuela de Fontainebleau.
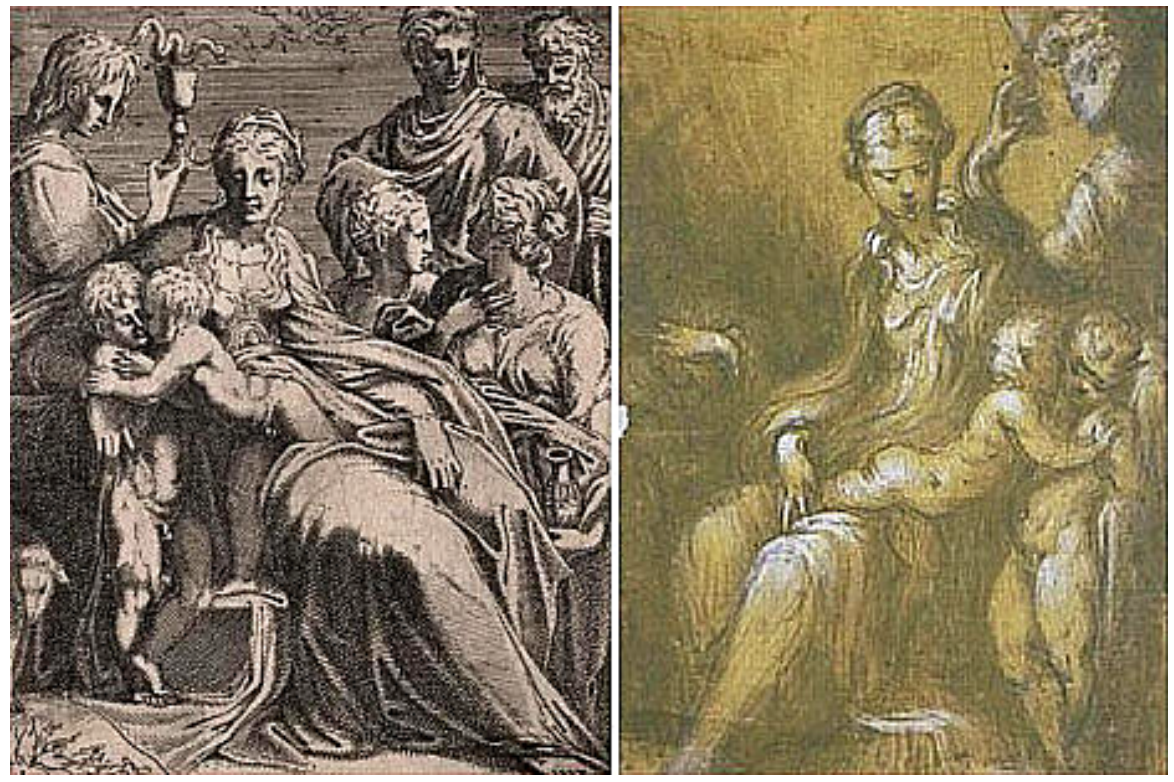

- Léon Davent. Sagrada conversación. Aguafuerte ca.1540 y dibujo de la escuela de Parmigianino que reproduce sus tipos característicos.

Los trabajos realizados en el palacio, ejemplo de realización colectiva, tuvieron en la creación de un taller y escuela de grabadores establecida in situ, el arma necesaria para documentar resultados y difundirlos por Europa. La forma de trabajar de los integrantes de dicha escuela de grabado no responde a un solo patrón, aunque predomina el de un artista, ducho en otra disciplina diferente como la pintura o la escultura, que se inicia allí en la técnica del aguafuerte reproduciendo composiciones ajenas y en algunas ocasiones también propias, con resultados progresivamente mejores. El carácter colectivo del proyecto decorativo de la obra que integra en un todo estucos, ornamentaciones y pinturas, tiene su equivalente en el testimonio que generó a través de la gráfica que es también integrador de influencias y opiniones de pintores, escultores y grabadores. Ejemplo por tanto de creatividad compartida y creación colectiva a tener en cuenta y analizar. Su interés se acentúa al constituir también un foco de difusión del manierismo de origen italiano, con influencias francesas y flamencas dado el carácter multinacional del grupo, desde el corazón geográfico de Europa.

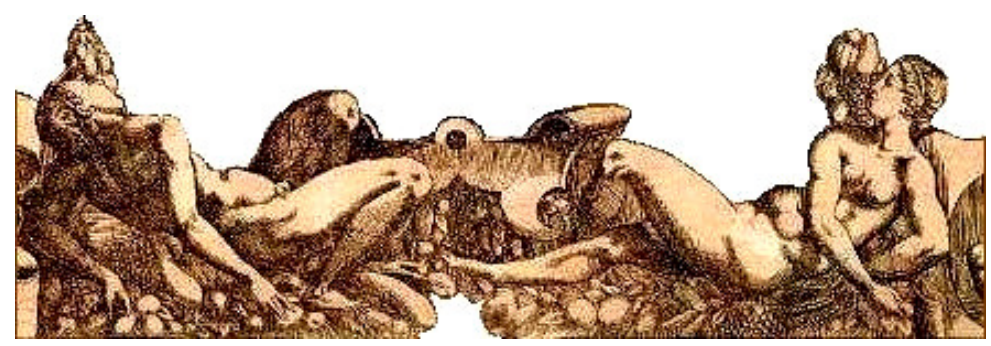


- La Escuela de Grabado de Fontainebleau.

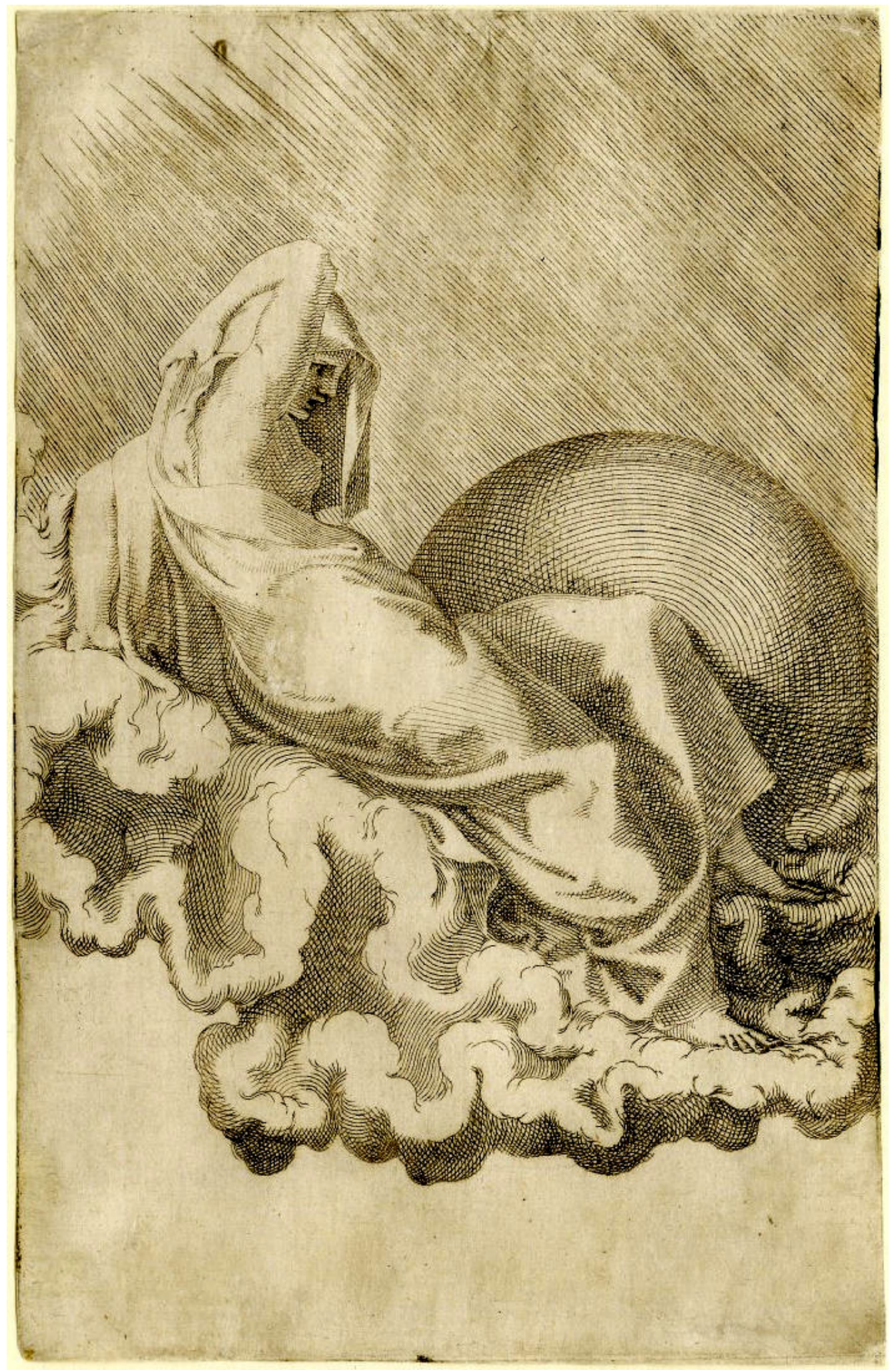

- Anónimo, según Léon Davent según Primaticcio. Urania. Aguafuerte.1540-55. 
La denominación Escuela de Fontainebleau aparece por vez primera de la mano de Adam Bartsch, gran estudioso vienés del grabado, en su vasta obra "El pintor grabador" de 1818. Allí agrupa una serie de obras de características comunes, producidas en torno a este enclave palaciego durante una época concreta, la década de los 40 y parte de los 50 del siglo XVI. Posteriormente la denominación se hará extensiva a toda la producción artística de ese brillante momento en el que pintores, escultores, estuquistas y grabadores llegan desde Italia y Flandes convocados por el rey Francisco I para unirse a los nacionales franceses y emprender el vasto proyecto arquitectónico, pictórico y decorativo que transformaría un antiguo castillo, el hasta entonces enclave cinegético de Fotaine-le-bel-eau, en el Palacio de Fontainebleau.

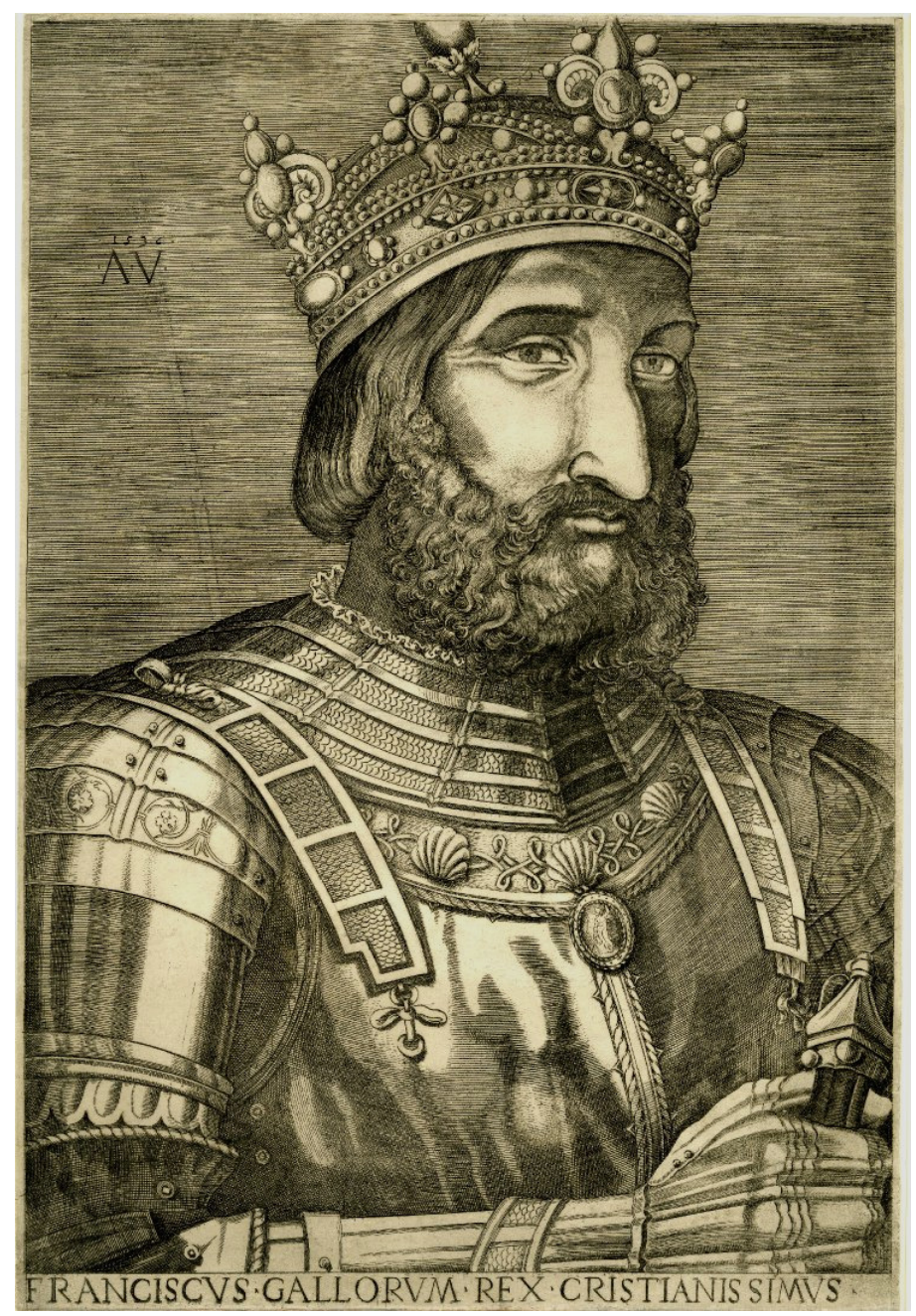

-Agostino Veneziano. Francisco I. Buril. 1535.

El interés del rey por el Renacimiento italiano ya contaba con el precedente de la presencia en su corte de artistas como Leonardo, fallecido allí, o Andrea del Sarto. Para acometer la transformación del difícil espacio arquitectónico del castillo contaría con los servicios de un artista plenamente manierista, Rosso Fiorentino que en 1531 ya está en Fontainebleau y un año después gracias a la influencia de Julio Romano, con los del joven Primaticcio que había sido ayudante suyo en la cámara de los estucos del Palacio del Té en la Mantua de los Gonzaga. 
La herencia del arte romano tras la diáspora artística de 1527 llega hasta Francia vía Julio Romano, heredero oficial de Rafael, Rosso Fiorentino y Primaticcio, a los que se añadirá después Luca Penni, también formado en el círculo rafaelesco.

El programa que Rosso emprenderá, integra lo pictórico y decorativo de forma indivisible, la influencia estilística entre pintores procedentes de centros distintos, hará que por ejemplo Primaticcio, cuya experiencia viene de Mantua y que nada tiene que ver con el manierismo exacerbado de Rosso, adquiera características en sus figuras dependientes de él. Al mismo tiempo Rosso templará notablemente su estilo. Las posteriores influencias sobre la escuela de la obra de Corregio y sobre todo de Parmigianino, acabarán conformando el aire común del grupo de autores que forman Fontainebleau, sin que ninguno de ellos pierda su particular impronta.

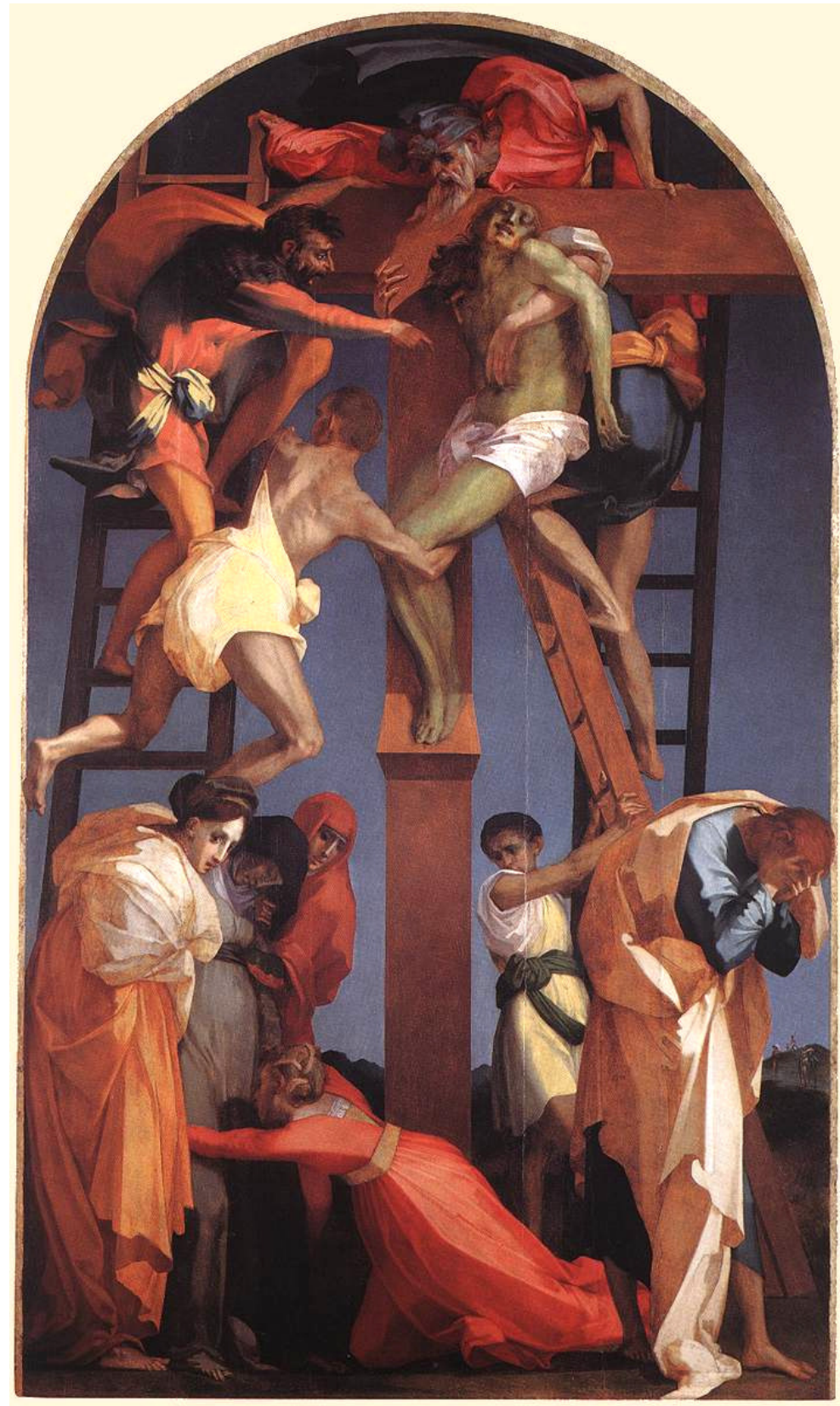

- Rosso Fiorentino. Deposición de la Cruz. 1521. Volterra. 

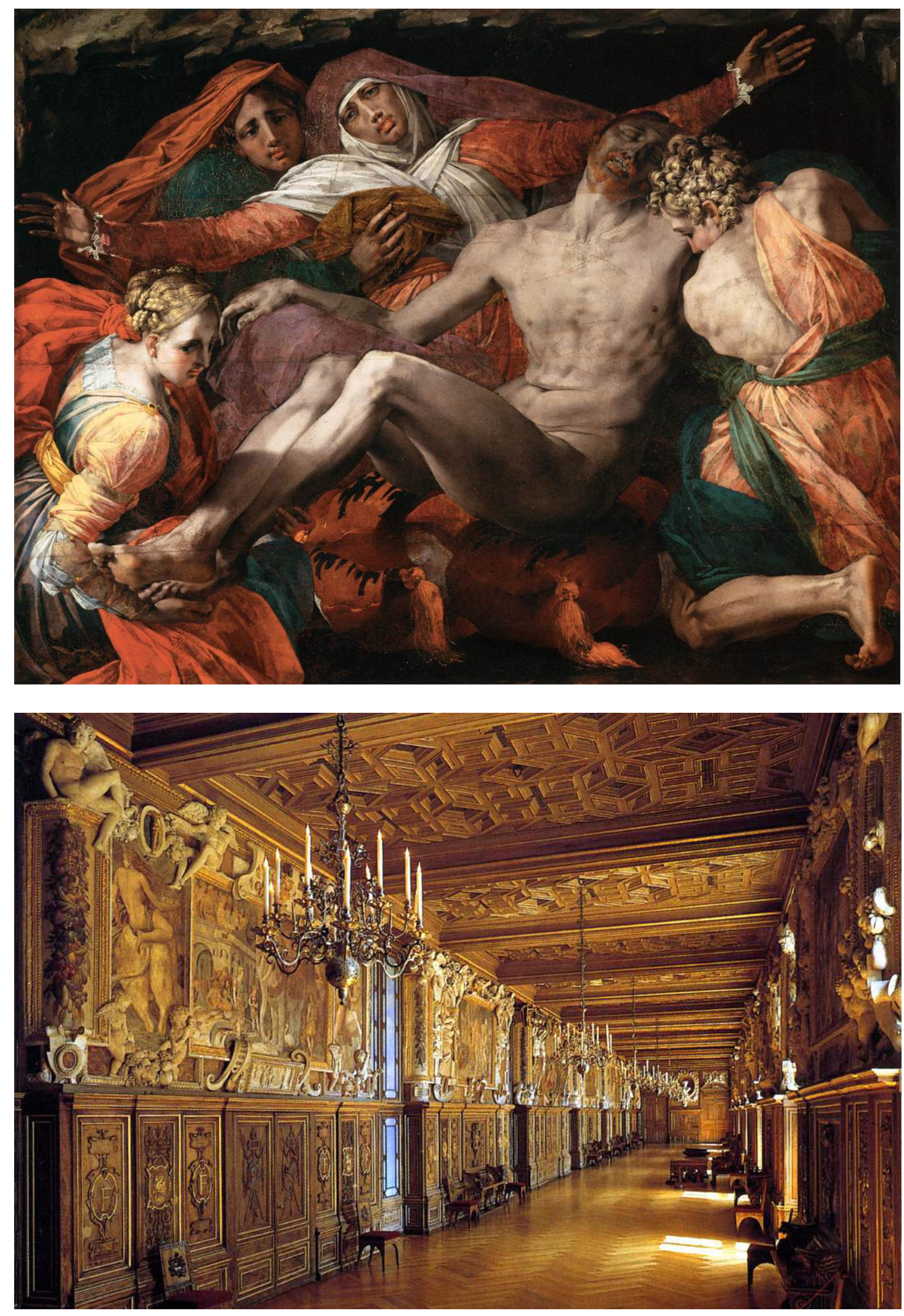

- Rosso Florentino. Pietá. 1538-40. Louvre, y Galería de Francisco I. Fontainebleau. 
En los libros de cuentas de las construcciones del Rey, figuran los nombres del equipo de artistas que trabajaron a las órdenes de Rosso y Primaticcio. Por su categoría vemos que ejecutan indistintamente trabajos de pintura y estuco, lo que dificulta su clasificación como pintores o escultores. Por nacionalidades primaron los italianos como Luca Penni, Pellegrino, Bartolomeo da Miniato o Nicoló Dell'Abate. Los franceses después: Simon Le Roy y Claude Baudoin y los flamencos, Léonard Thiry entre ellos.

En el estilo imperante en Fontainebleau, influye el manierismo italiano por imposición de sus principales responsables y también el gusto particular del rey y las colecciones de obras maestras que atesoraba de autores como Leonardo, del Sarto o Miguel Ángel. Pero la mezcla de nacionalidades de los artistas que realizan la obra y la influencia del encuadre arquitectónico, todavía dependiente de un goticismo tardío, dotan al conjunto de un carácter totalmente original.

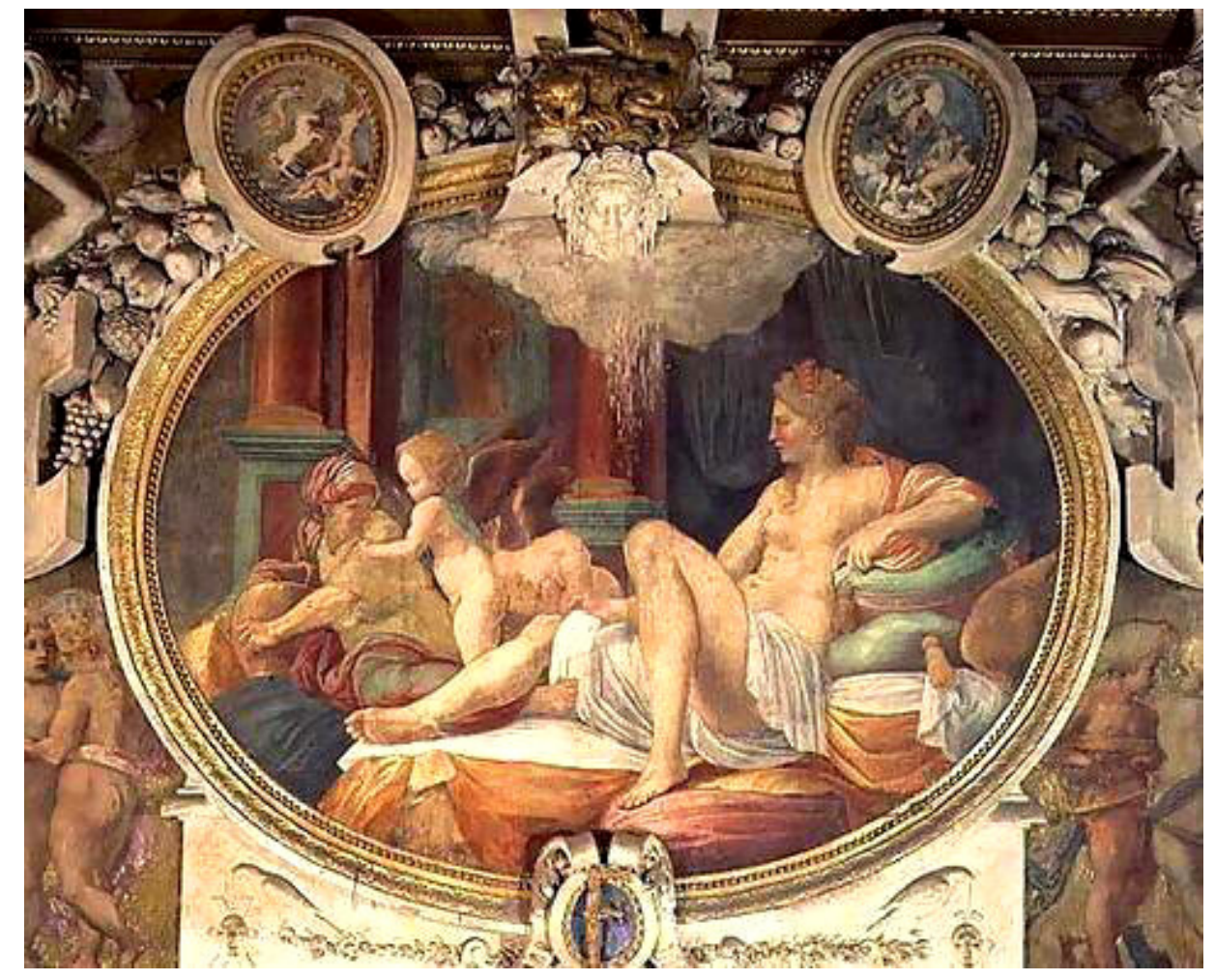

- Francesco Primaticcio. Danae y la lluvia de oro. Fresco de la galería Francisco I.1539

La desaparición de Rosso Florentino en 1540, cuyo carácter siempre inestable hace verosímil la versión que se baraja de un suicidio, dejó en las manos de Primaticcio la responsabilidad artística y laboral del gran proyecto Fontainebleau. Los resultados fueron inmejorables y Primaticcio permanecería en Francia hasta el fin de sus días en 1570. Varios viajes a Roma y al resto de Italia, enviado por Francisco I para comprar obras y reproducciones de piezas clásicas para su colección, le sirvieron también para seguir reclutando colaboradores, como Luca Penni (hermano de Gianfrancesco, colaborador directo de Rafael) y de asimilar la influencia de otros artistas italianos que tendrían mucho que ver con la obra en curso, como Parmigianino.

En estas circunstancias es cuando se produce la aparición de las primeras estampas 
grabadas y cabe pensar que su producción se debe a la iniciativa de Primaticcio. La toma de conciencia de la importancia que el proyecto tenía y de los logros obtenidos pudo propiciar el deseo de difundir los resultados. El éxito fue considerable e inmediato.

En Fontainebleau, la gran abundancia de proyectos y la premura por avanzar en su realización, dan en lo pictórico una gran preponderancia al dibujo. Los mismos motivos hacen que en el campo del grabado se imponga el uso del aguafuerte sobre el del buril. El manejo de la punta sobre la superficie barnizada es fácil para cualquier buen dibujante, mientras que la talla dulce exige un aprendizaje largo y una realización más lenta y minuciosa. La mayor parte de las estampas son como consecuencia aguafuertes. En los primeros momentos realizados con una cierta premura y deficientemente procesados en el ácido, lo que nos da pié a pensar que la iniciativa de su producción era dejar constancia del trabajo que se realizaba en el palacio más que comercializar los resultados, aunque este objetivo no estuviera excluido. Tiempo después editores franceses, flamencos e italianos publicarían ediciones de las estampas de Fontainebleau. Uno de ellos Antonio Lafreri o Antoine Lafrèry, francés instalado en Roma, fue largos años socio del español Antonio Salamanca, ambos relacionados con Marcantonio Raimondi y los colaboradores y seguidores de su escuela.

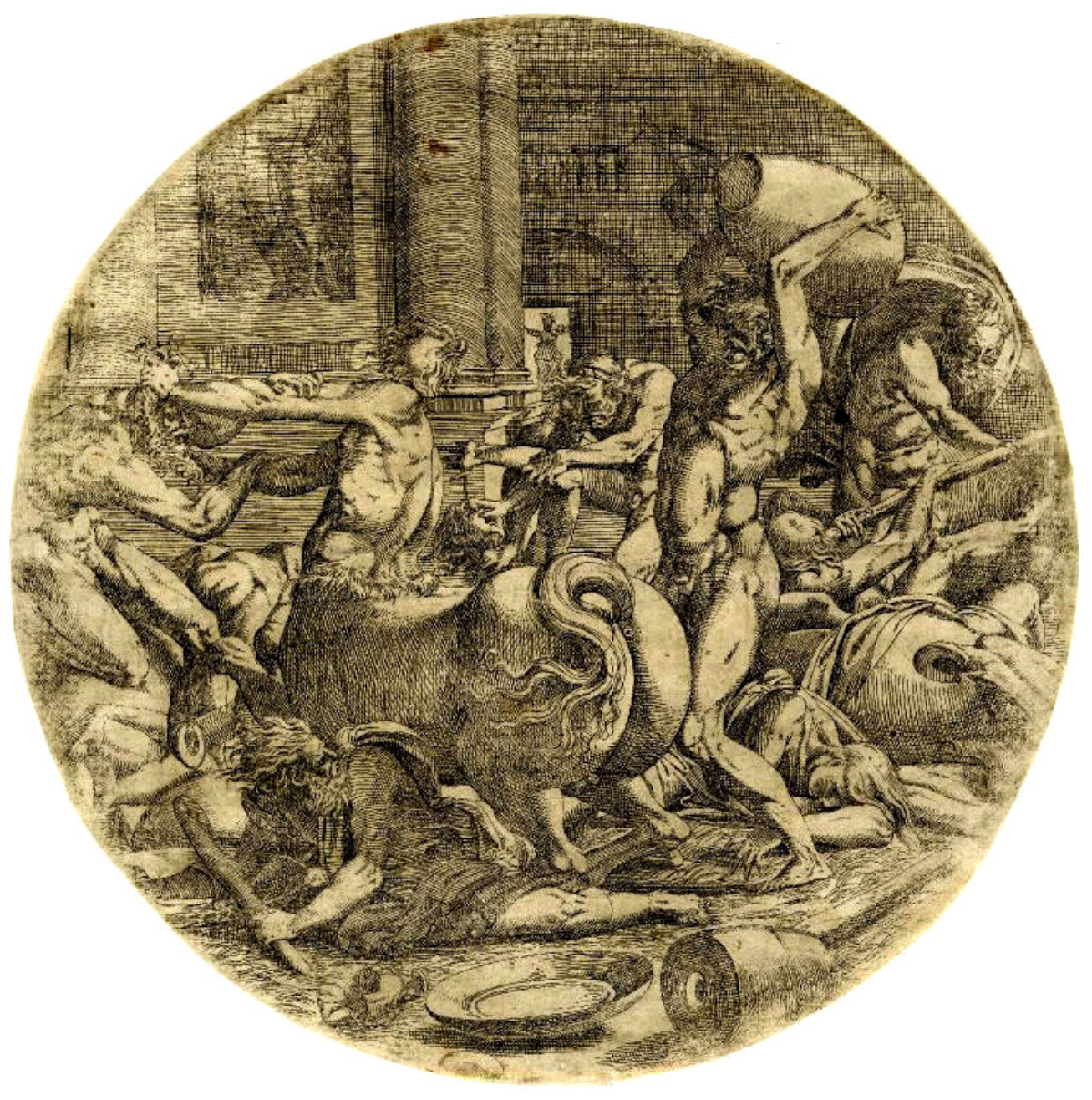

- Antonio Fantuzzi según Rosso. Centauros y Lapitas. Aguafuerte. 1540-45. 
La iconografía y los asuntos representados, al igual que en los frescos, corresponden al gusto renacentista por los temas mitológicos y la historia antigua grecorromana, impregnados de un erotismo cortesano sin tapujos que inicia una tradición ya nunca abandonada en la historia del arte francesa. La temática religiosa también está presente algo obligado en el palacio de una corte católica como la de Francisco I. La concepción monumental del proyecto, inspirada por Julio Romano y los tipos humanos: hombres de amplio torso, mujeres de largo cuello, opulentas y de poderosas caderas, deudores de Rosso y Parmigianino, son en lo formal característicos de esta escuela difundida a través de la obra gráfica por toda Europa.
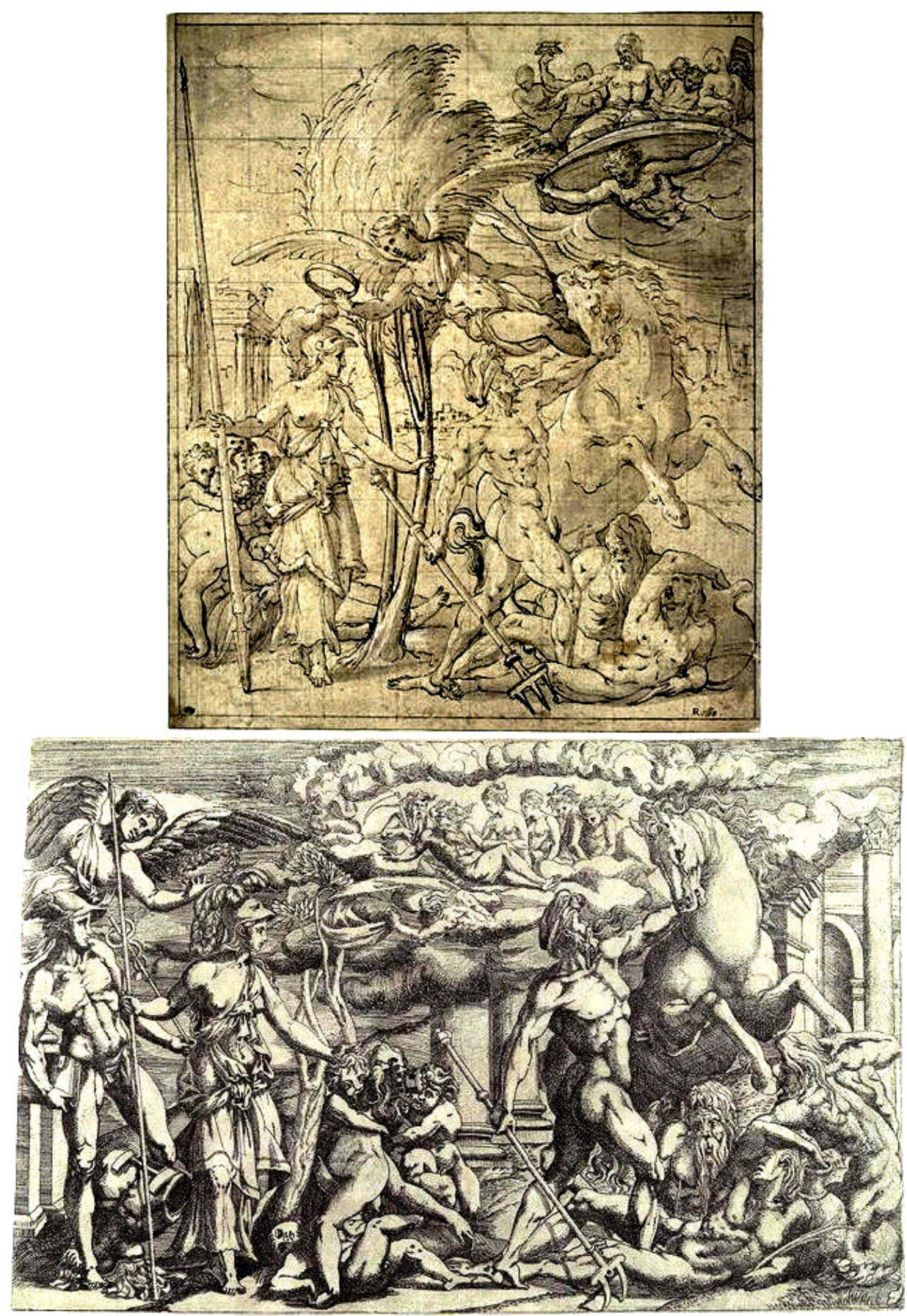

- Rosso, dibujo y Fantuzzi, aguafuerte. Disputa de Poseidón y Atenea. 1543 $-128-$ 


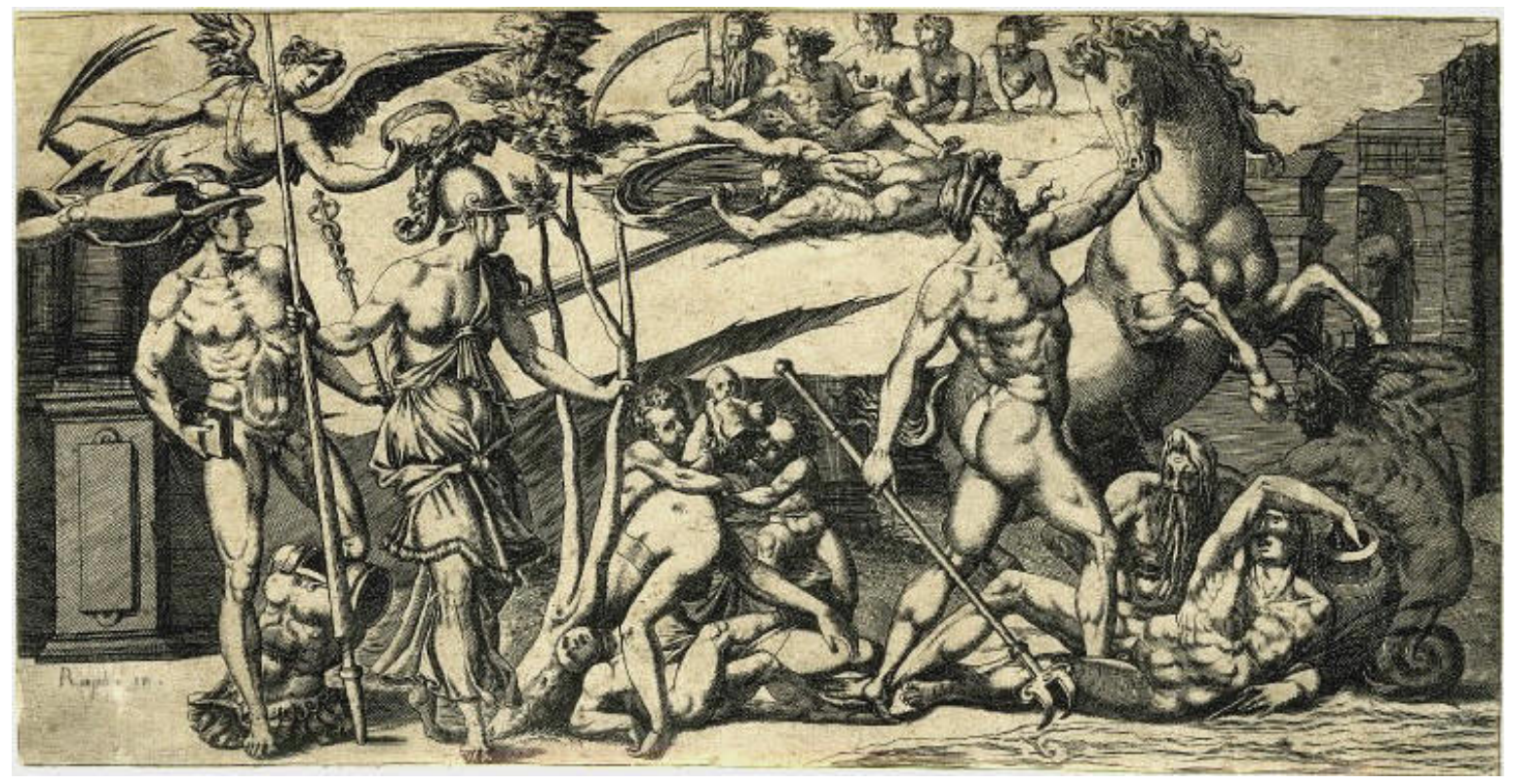

-René Boyvin. Disputa de Poseidón y Atenea. Buril.1545-50.

Los autores que suministraron los originales para ser grabados son los directamente implicados en los trabajos: Rosso Florentino, Francesco Primaticcio, Luca Penni y el flamenco Léonard Thiry, además de los que les influyeron, Julio Romano y Parmigianino. Andrea del Sarto y Miguel Ángel, presentes en la colección de Francisco I, son seguidos en algunas estampas. También encontramos algunas composiciones influenciadas por Marcantonio Raimondi y su escuela.

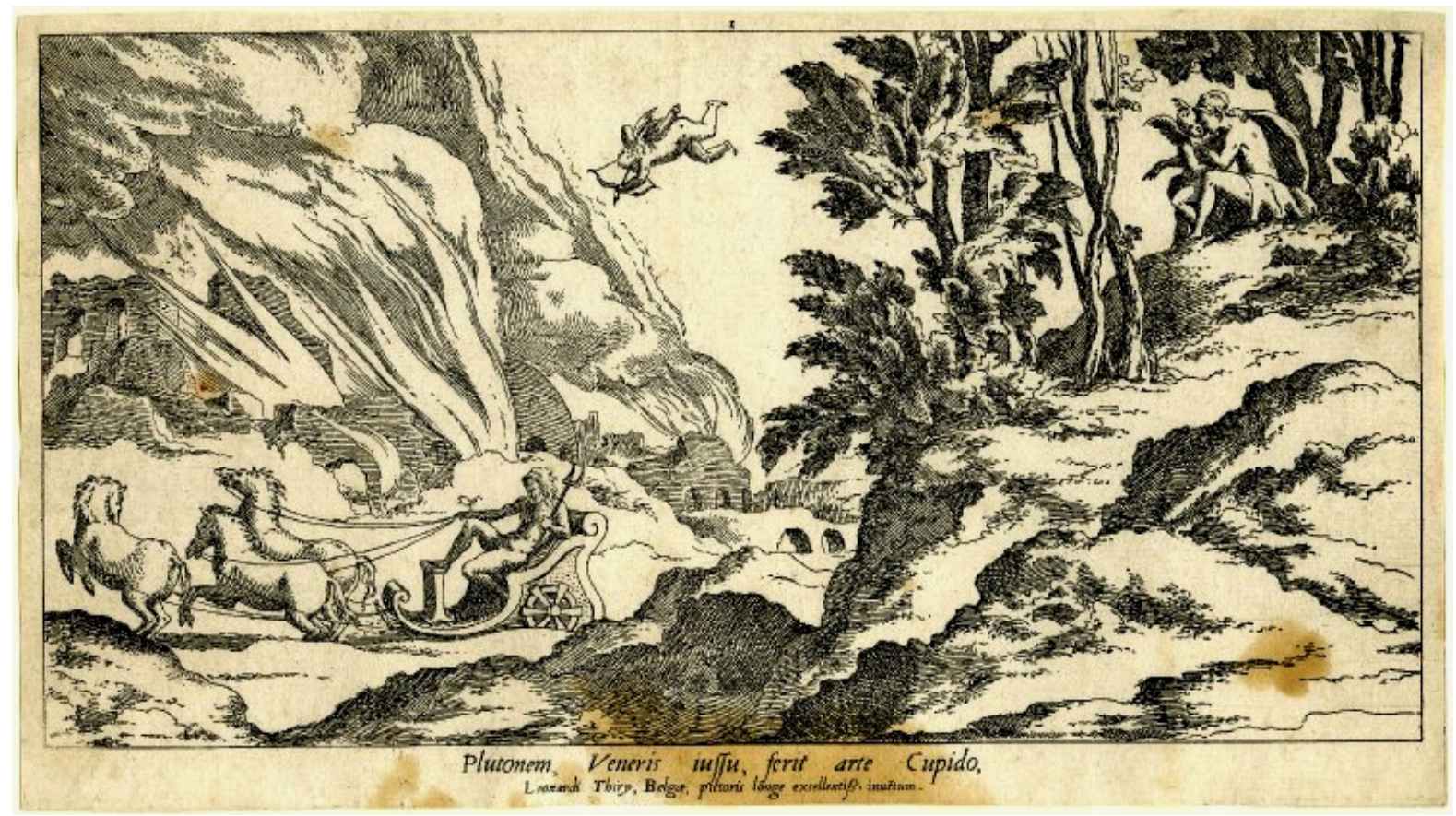

- Léon Davent según Léonard Thiry. Paisaje con Plutón Venus y Cupido.

Aguafuerte.1547 

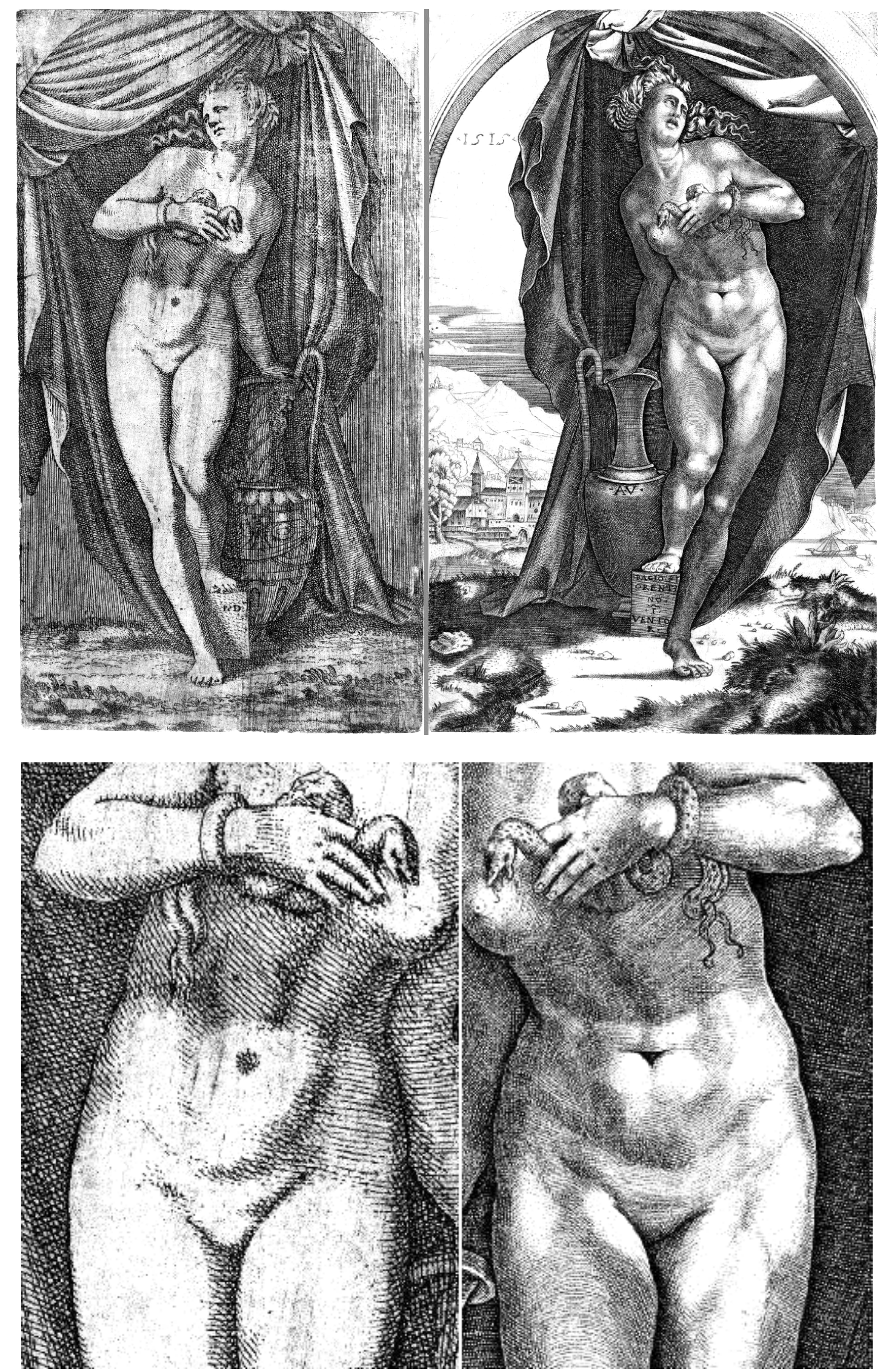

- Léon Davent, aguafuerte, 1544 y Agostino Veneziano según Baccio Bandinnelli, buril. El suicidio de Cleopatra. Comparación de obras y detalles. 

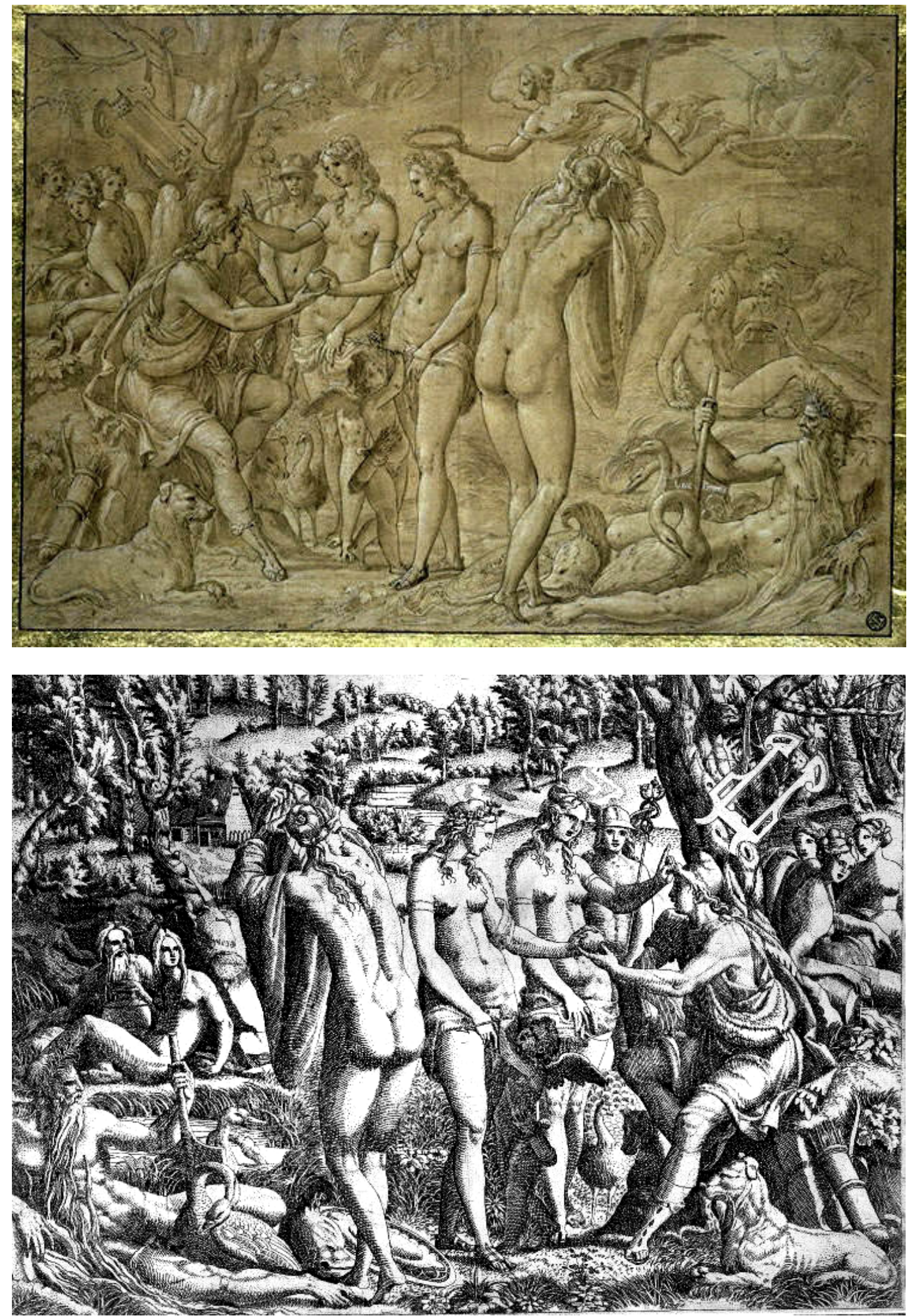

- Luca Penni, dibujo y Jean Mignon, aguafuerte. El Juicio de Paris. 1543-45. 
Sin duda, las obras de Raimondi son conocidas en Fontainebleau a través de varias vías. Gran parte del equipo es italiano y Luca Penni se debió relacionar directamente con él. En este dibujo original de Penni, que representa el Juicio de Paris, se observa la influencia de la famosa estampa de Marcantonio, recreada pero indiscutible.

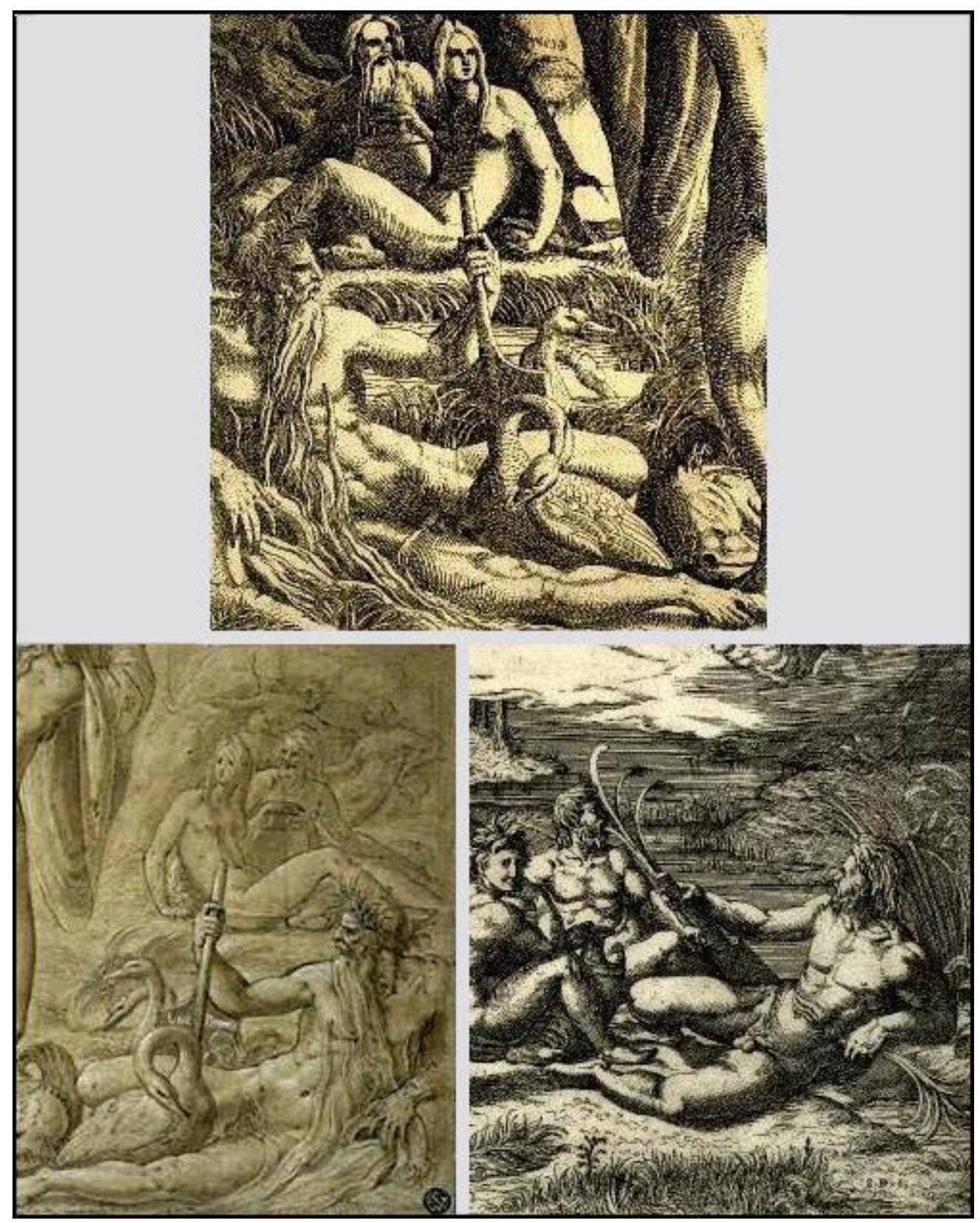

- El Juicio de Paris. Detalles del Dios Fluvial en el grabado de Jean Mignon, el dibujo de Luca Penni en que se basa y una obra de Etienne Duperac que reproduce el original de Marcantonio Raimondi según Rafael. 
La aplicación práctica de la codificación gráfica conseguida por Raimondi no constituye más que un instrumento auxiliar para los grabadores de Fontainebleau. Igualarla o perfeccionarla no parece estar entre sus objetivos.

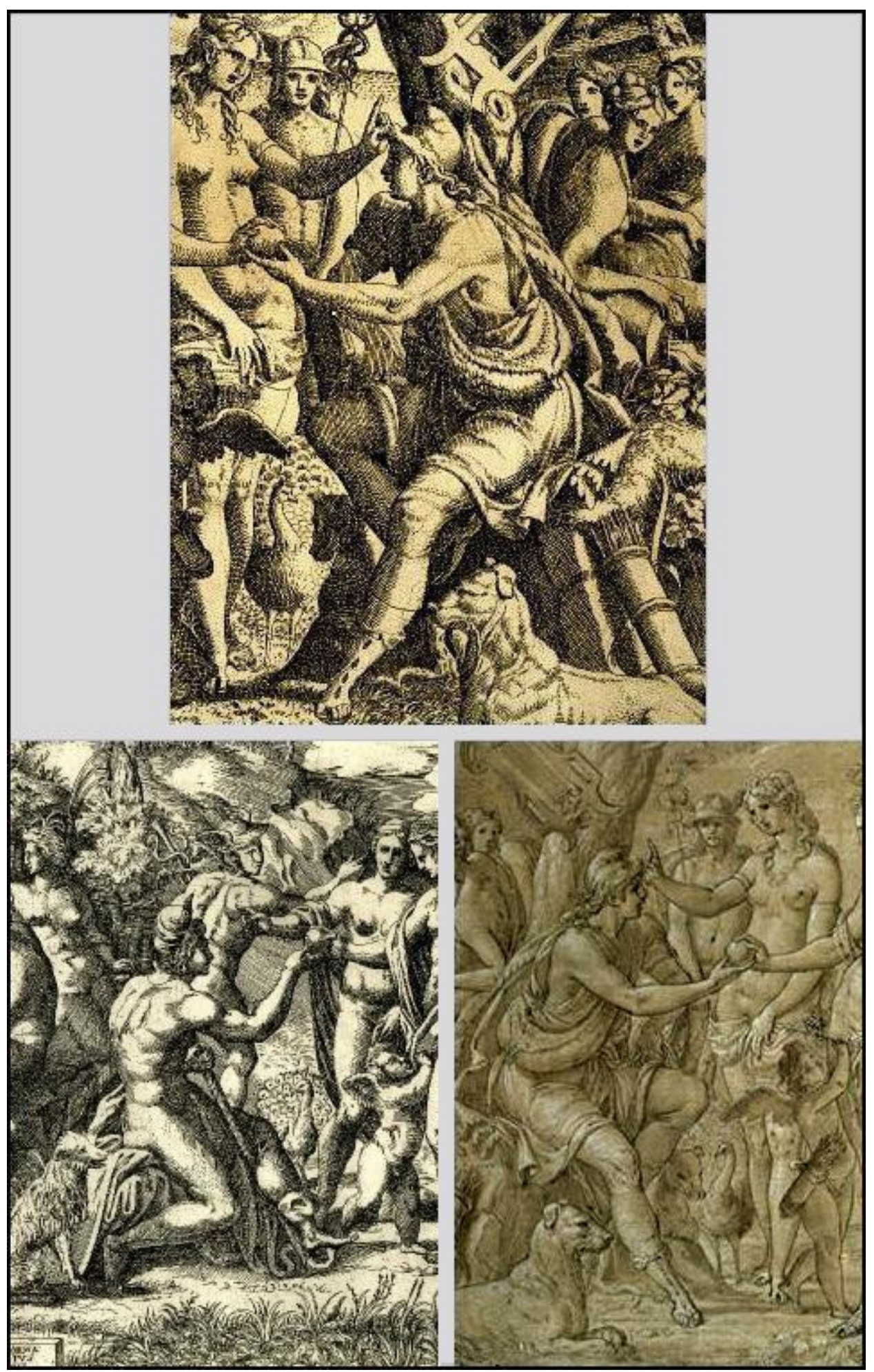

- Detalles de las mismas obras con Paris ofreciendo la manzana. 


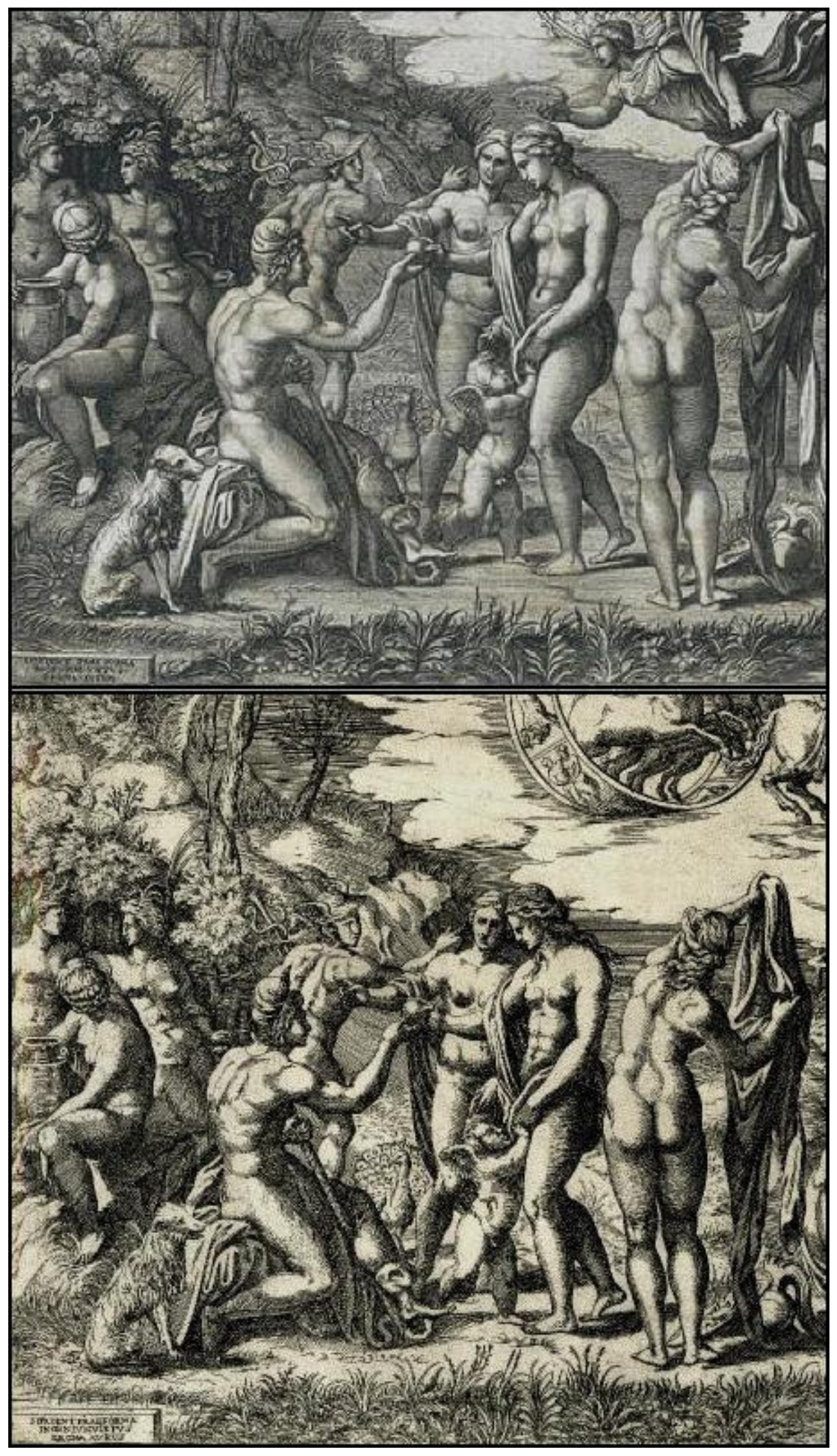

- Marcantonio Raimondi, buril. ca.1517 y Etienne Duperac, aguafuerte. ca. 1568. El Juicio de Paris. Detalles comparados. 
Entre los grabadores que formaron esta escuela el problema de las atribuciones está siempre presente y hay un gran número de estampas anónimas, sobre todo entre las que representan conjuntos ornamentados en estuco, en los que la falta de monogramas, fecha y lo uniforme del tema, hacen difícil identificar la autoría.

La producción más numerosa de estampas proviene del taller creado en el propio Fontainebleau entre los años 1542 y 1547, con una producción mayor entre el 43 y el 45. A ello hay que añadir obras producidas en otros lugares de Francia, París fundamentalmente, deudoras de la estética belifontana.

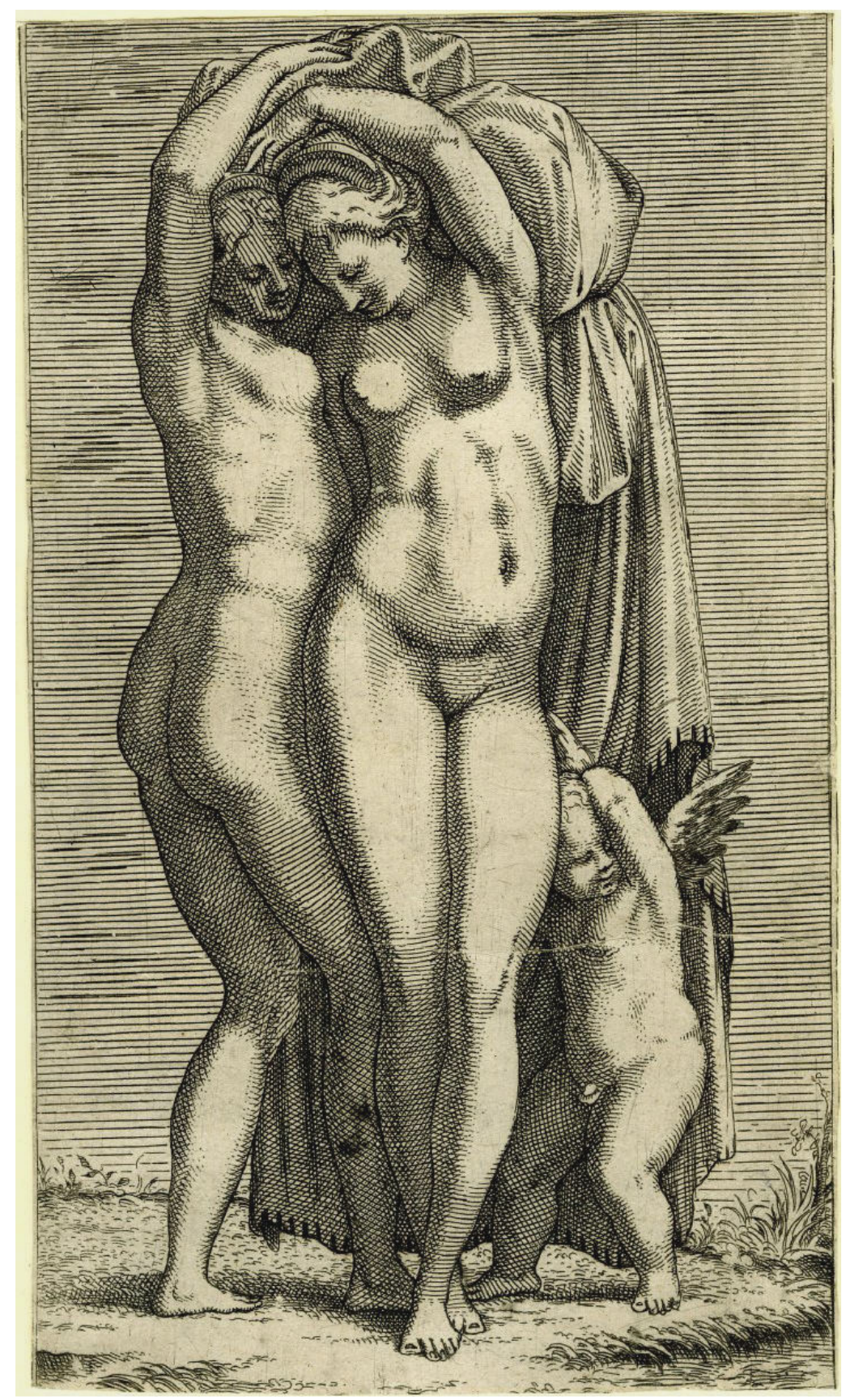

- Léon Davent según Primaticcio. Dos mujeres y Cupido. Aguafuerte. ca.1545. 
Son los más importantes grabadores de la escuela: Antonio Fantuzzi, el maestro IQV, Léon Davent, Jean Mignon, René Boyvin, Geoffroy Dumoûtier, Domenico del Barbiere, Pierre Milan $Y$ Juste de Juste. Entre ellos encontramos artistas contratados para otros menesteres, como es el caso de Antonio Fantuzzi. Cada autor suele reproducir con más asiduidad a uno de los pintores principales presentes en el proyecto que al resto, Jean Mignon a Luca Penni o Léon Davent a Primaticcio, aunque sin exclusividad en ningún caso.

Es posible determinar dos tendencias dentro de la producción de Fontainebleau, asociadas a las figuras de Primaticcio y Luca Penni. Tras la muerte de Rosso sin herederos, sus bienes pasan al patrimonio Real, pero el legado profesional que incluye una amplia colección de dibujos propios y de Julio Romano o de Andrea del Sarto, quedan en poder de Primaticcio. Con este conjunto de obras además de las suyas, Primaticcio pudo impulsar en 1542 la creación del taller de grabado.

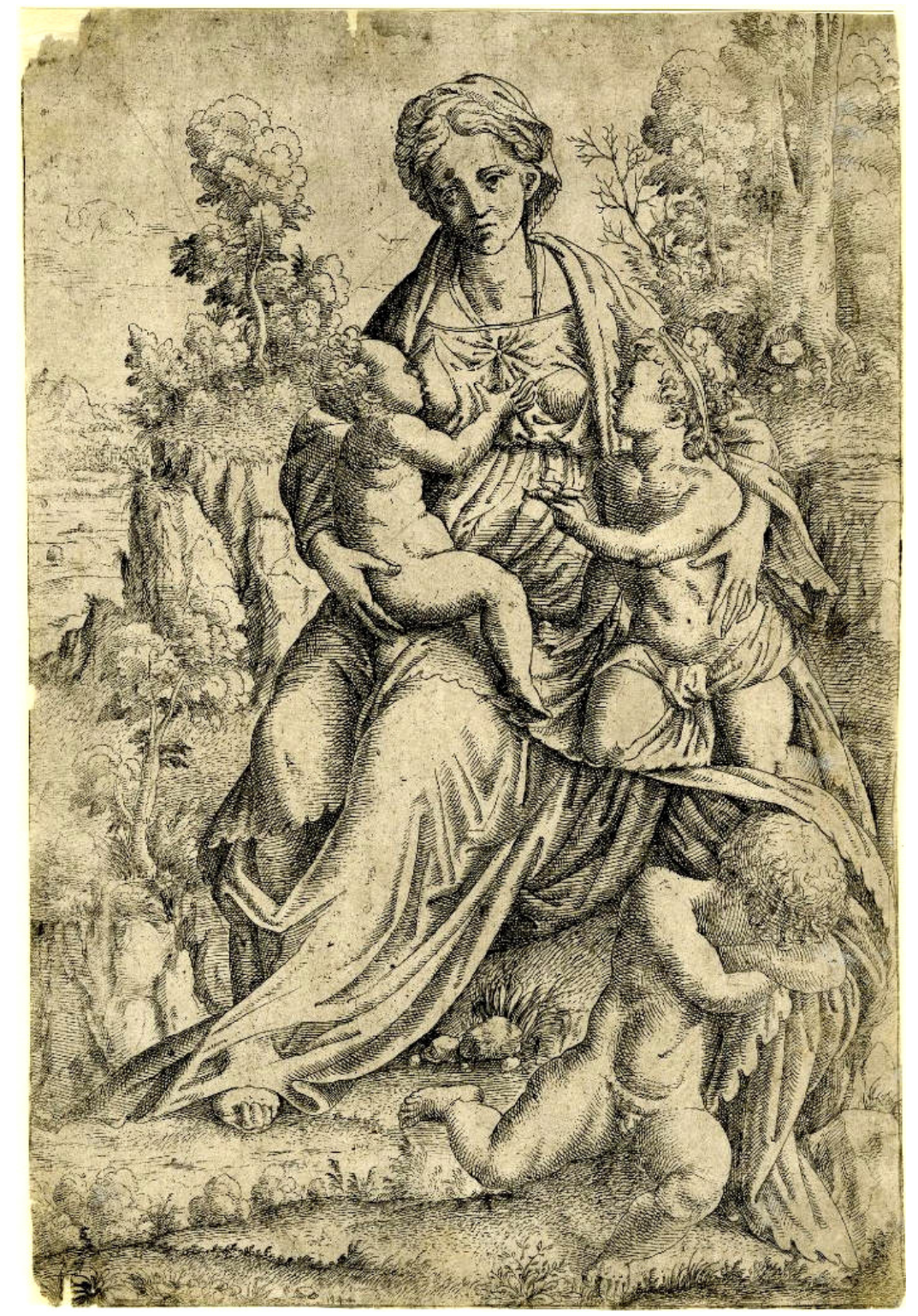

- Jean Mignon según Andrea del Sarto. Caridad. Aguafuerte. 1544. 
Las obras dependientes de originales de Luca Penni se incrementan en los últimos años de producción. Este artista que trabajó en el lugar siguiendo un esquema similar al de Primaticcio, parece desarrollar una labor diferenciada en la producción gráfica. Jean Mignon, Léon Davent y René Boyvin realizan un gran número de estampas según sus dibujos. Cuando en 1547 declina la actividad del taller, Luca Penni sigue produciendo y posteriormente editando sus obras en París. Su interés especial por la profesión de grabador la atestigua el hecho de que emplazara a su hijo como aprendiz en el taller de Boyvin, con el que al parecer mantenía lazos amistosos.

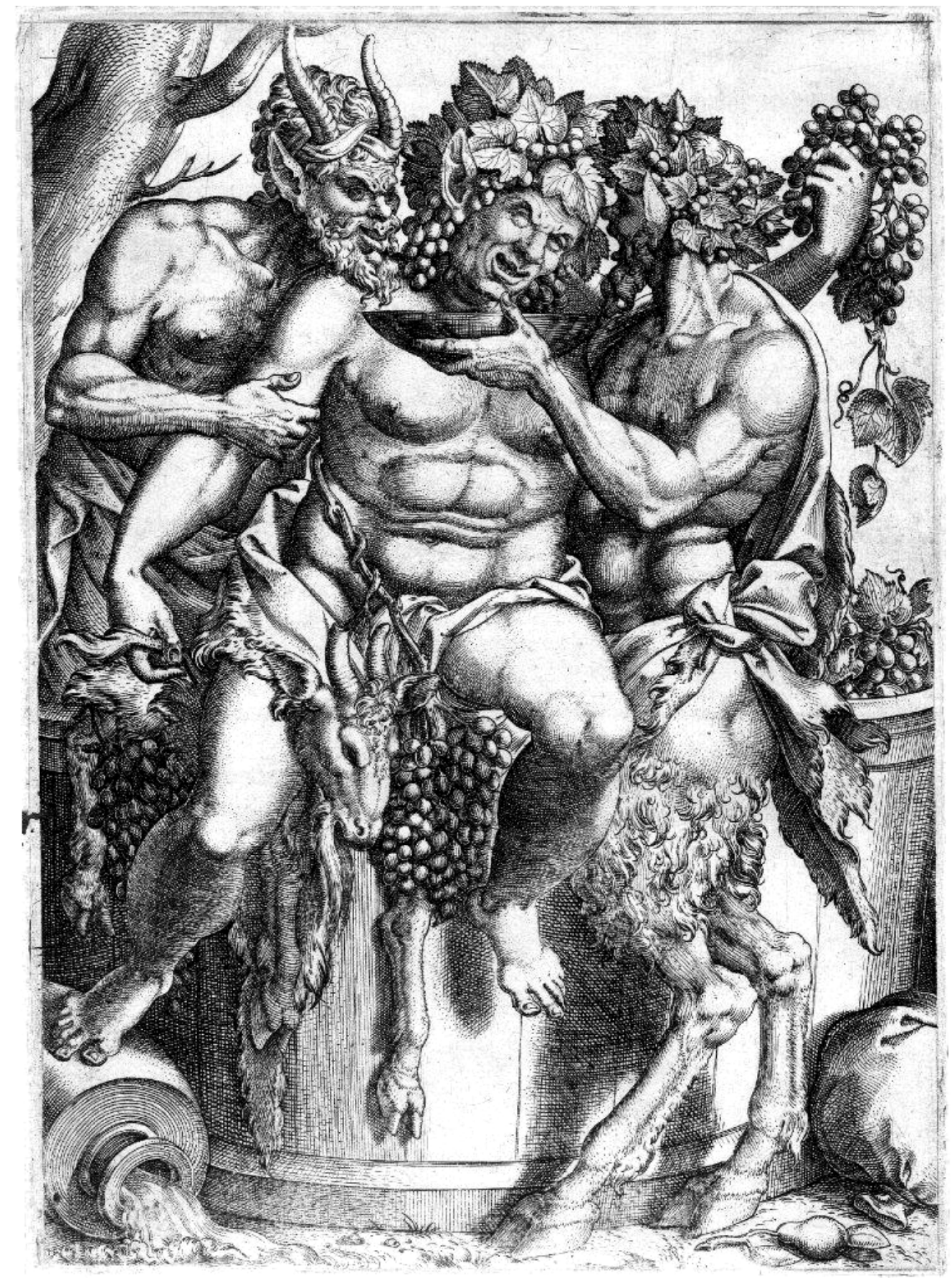

- Anónimo según Boyvin según Penni. Sileno y faunos. Aguafuerte. 1550-60. 
Los grabados a buril representando ornamentos o grandes composiciones, constituyen la parte más comercial del proyecto. Más detallados y cuidados en su ejecución, una gran parte de ellos es realizada en París por lo que quizás no estén tan identificados con la esencia de la obra gráfica creada in situ.

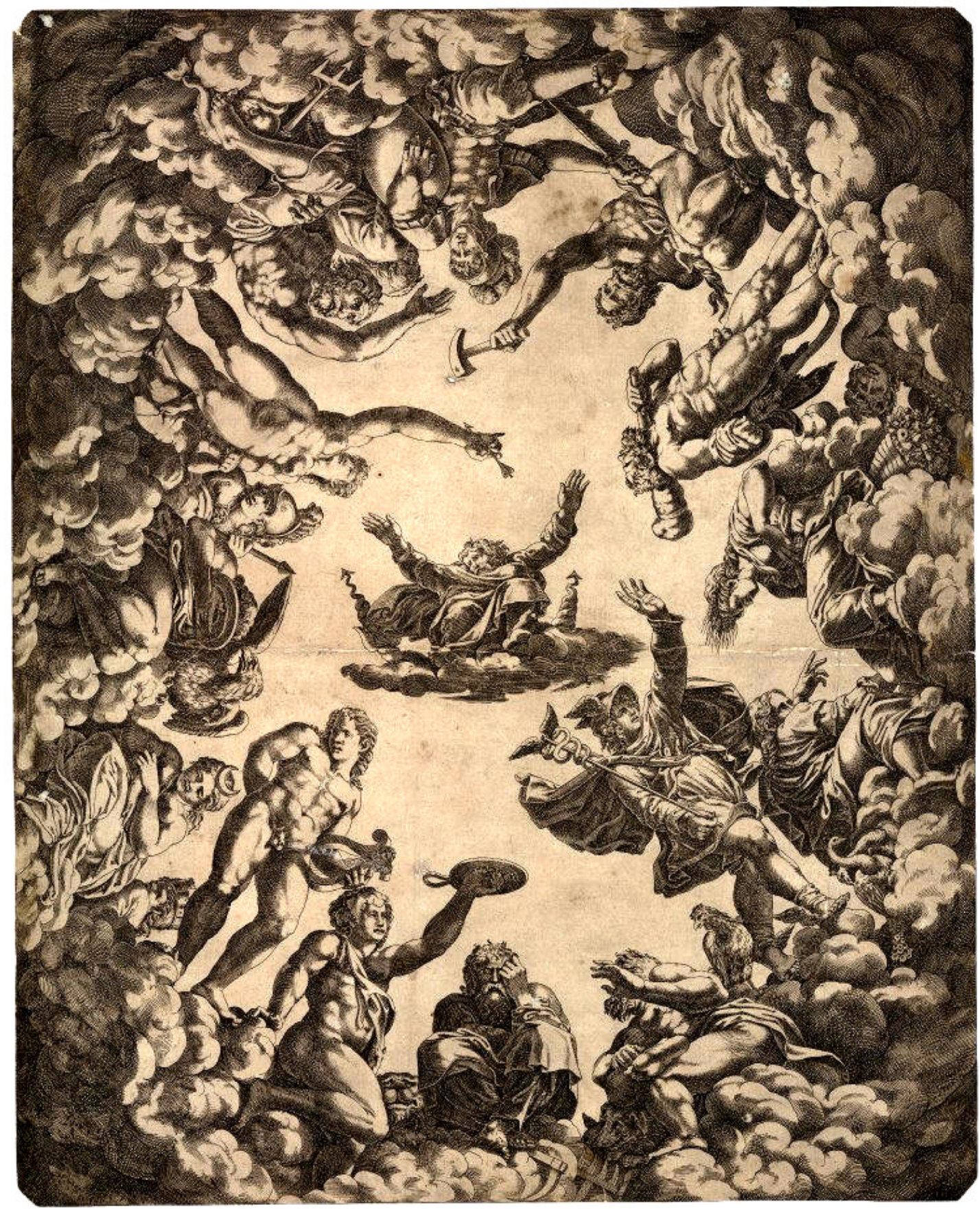

- René Boyvin o Pierre Milan según Primaticcio. Bóveda de Júpiter y la asamblea de los dioses. Buril. 1545-60. 
Los grabados al aguafuerte, debido a su espontaneidad, resultan más fieles al espíritu del proyecto Fontainebleau. En los primeros años de su ejecución, (1542-44), la producción es masiva y también algo descuidada. Parece responder a la voluntad de publicar un manifiesto en el momento exacto en que se esta consolidando el arte belifontano.

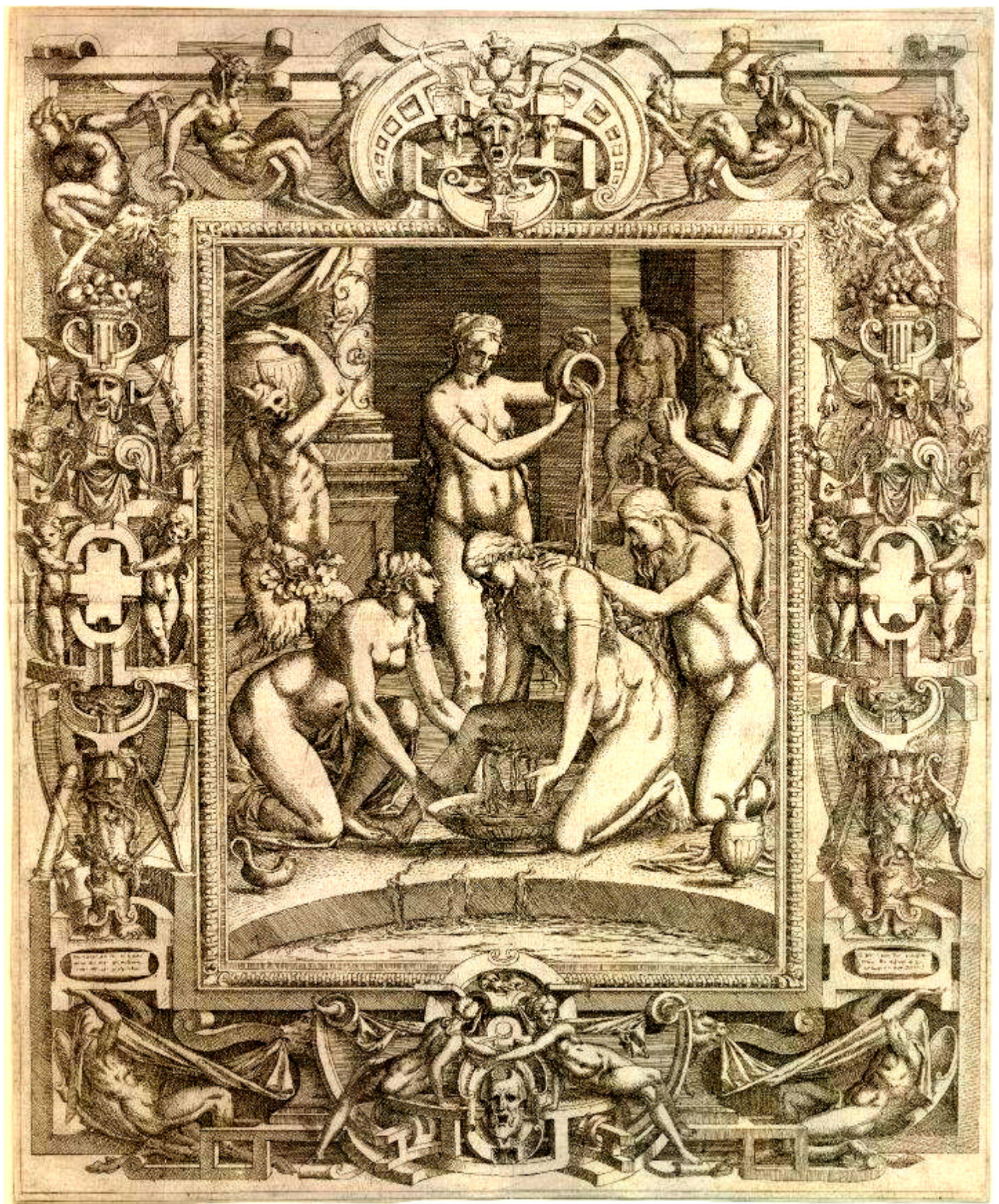

- Jean Mignon según Luca Penni. El Baño de Venus. Aguafuerte. 1543-45. 
Del castillo-palacio proyectado por Francisco I y continuado por sus sucesores han llegado hasta nuestros días la famosa Galería del Rey, la Cámara de la Duquesa d'Étampes, la Puerta Dorada y el Salón de Baile. Otras secciones del edificio lamentablemente resultaron destruidas en el curso de la historia, como ocurrió con la tan alabada Galería de Ulises. Es solo gracias al testimonio que nos ofrece la obra gráfica realizada a partir de los frescos y decoraciones desaparecidas que podemos imaginar la realidad de su tiempo y tener un registro de los temas e imágenes allí representadas.

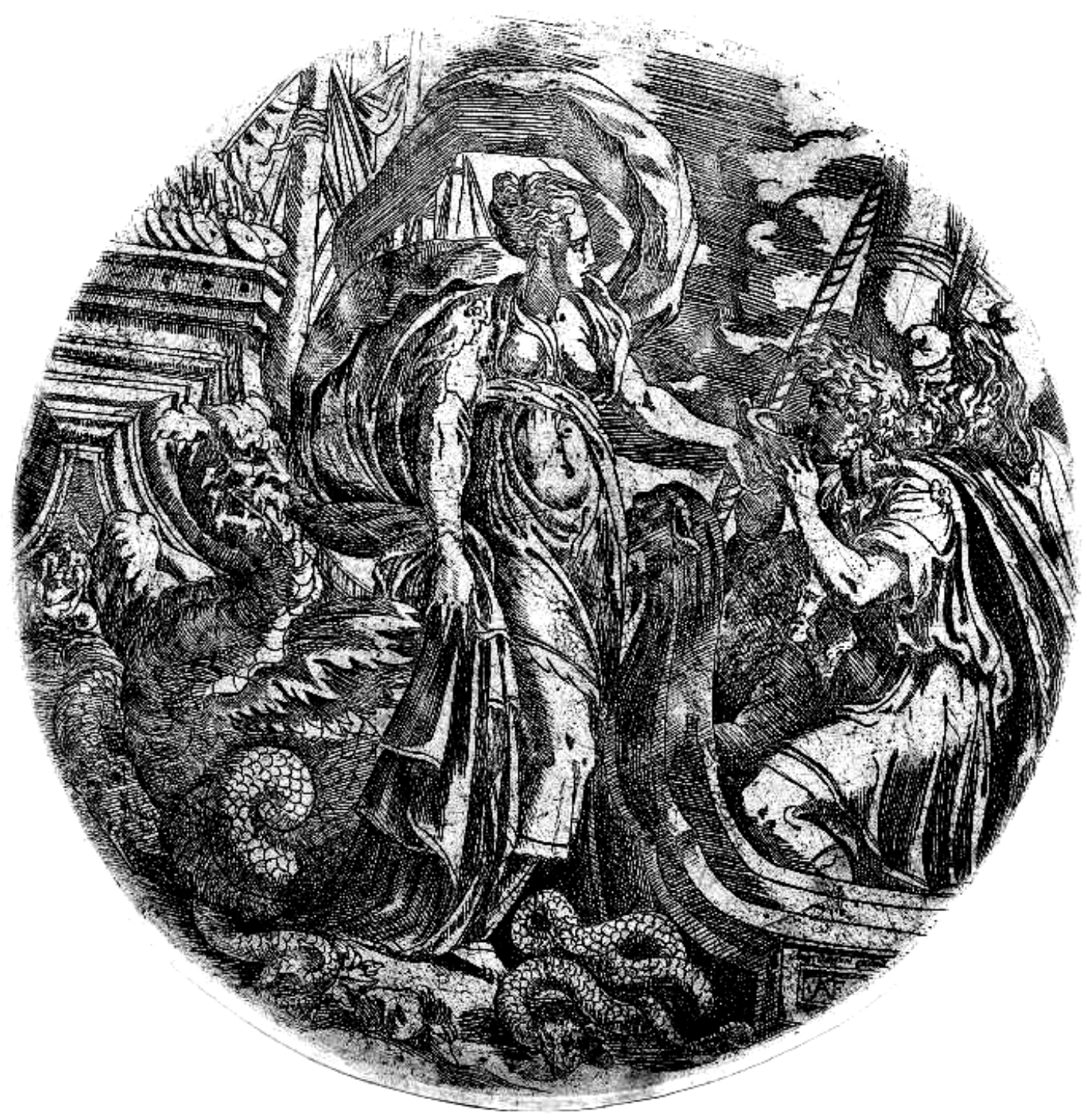

- Antonio Fantuzzi según Parmigianino. Circe dándole a Ulises la pócima que le convertirá en puerco. Aguafuerte. 1542.

Antonio Fantuzzi, ca.1508-1550. De orígenes poco documentados, casi con seguridad boloñés, pudo haber llegado a Fontainebleau en el sequito de Primaticcio. En los registros de la construcción figura como pintor, estuquista y grabador. De su obra como pintor nada se sabe pero es seguro que realizó dibujos grotescos para las decoraciones que enmarcaron los frescos. Fantucci parece poco experto en grabado cuando se inicia en su producción, con ciertos problemas técnicos en el mordido de los 
aguafuertes y rayados irregulares, pero pronto desarrolló un estilo más libre y regular. Los densos entrecruzados que sombrean los perfiles de las figuras y los interiores de estas no trabajados, son característicos de sus imágenes.
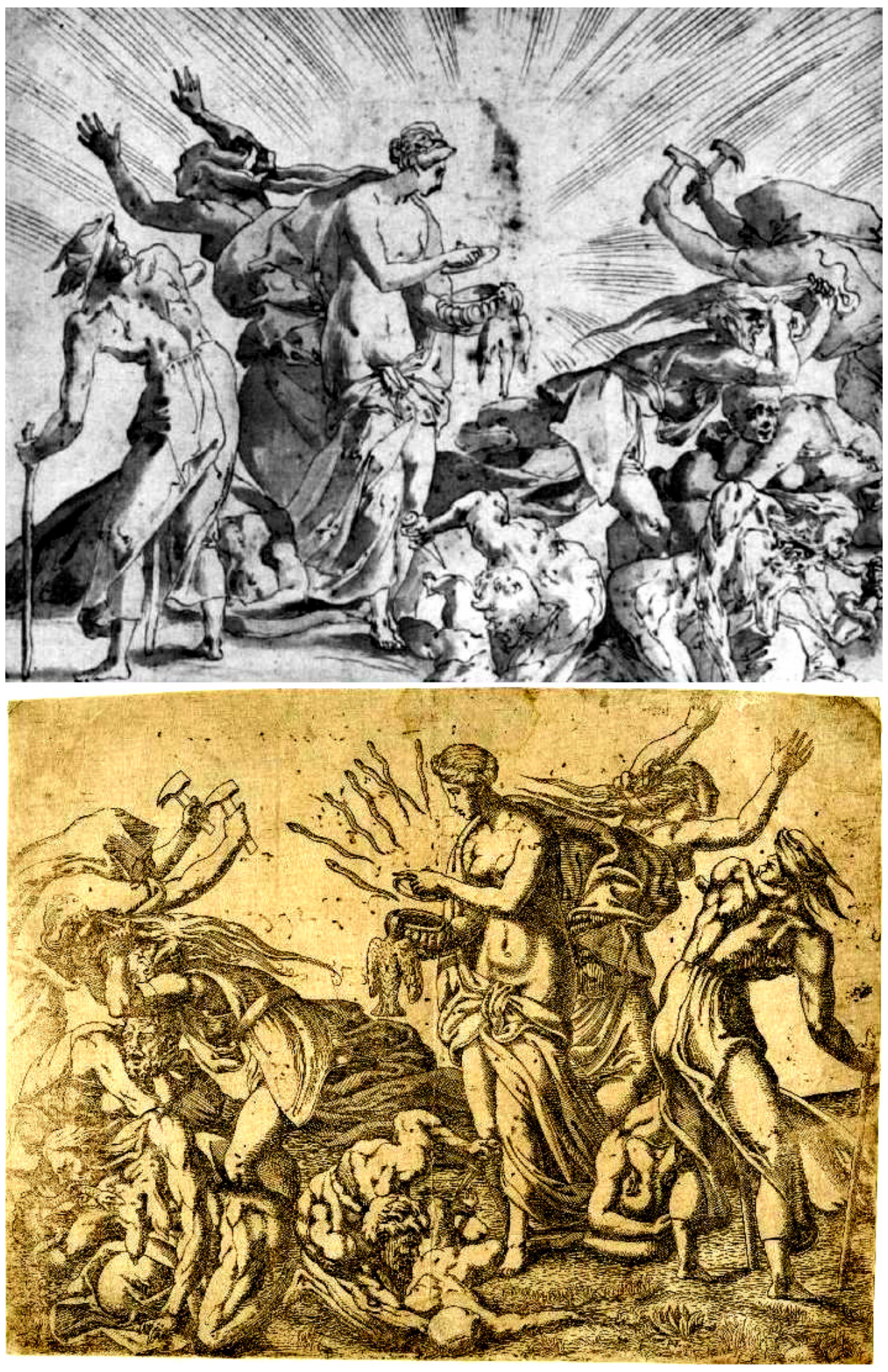

-Rosso, dibujo y Fantuzzi, aguafuerte. Pandora esparciendo los males por el mundo. 1542. 


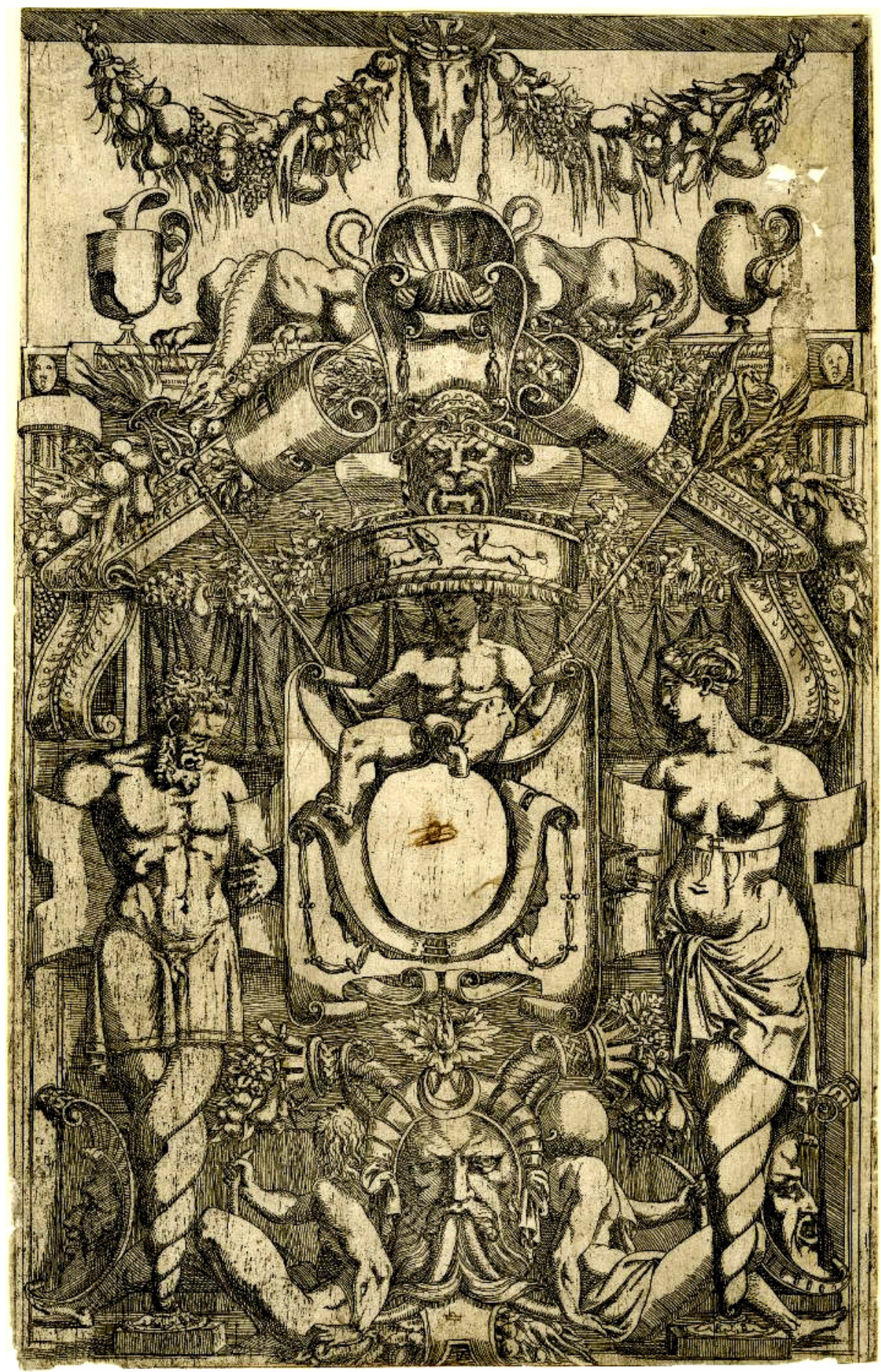

- Antonio Fantuzzi. Panel decorativo. Aguafuerte. 1542-45.

Entre los elementos decorativos de los paneles de estuco, ampliamente representados en la obra grabada de Fantuzzi, los más utilizados en Fontainebleau son los cueros, piezas regulares de bordes enroscados que aunque tienen precedentes en decoraciones italianas, son aquí utilizados con una profusión insólita, junto a ellos : guirnaldas, cráneos, máscaras, putti, termes, frutos, conchas y muchos otras figuras simbólicas que rodeando las composiciones pictóricas enmarcadas en óvalos, cuadrados o círculos, forman con ellas un todo característico de esta escuela. 


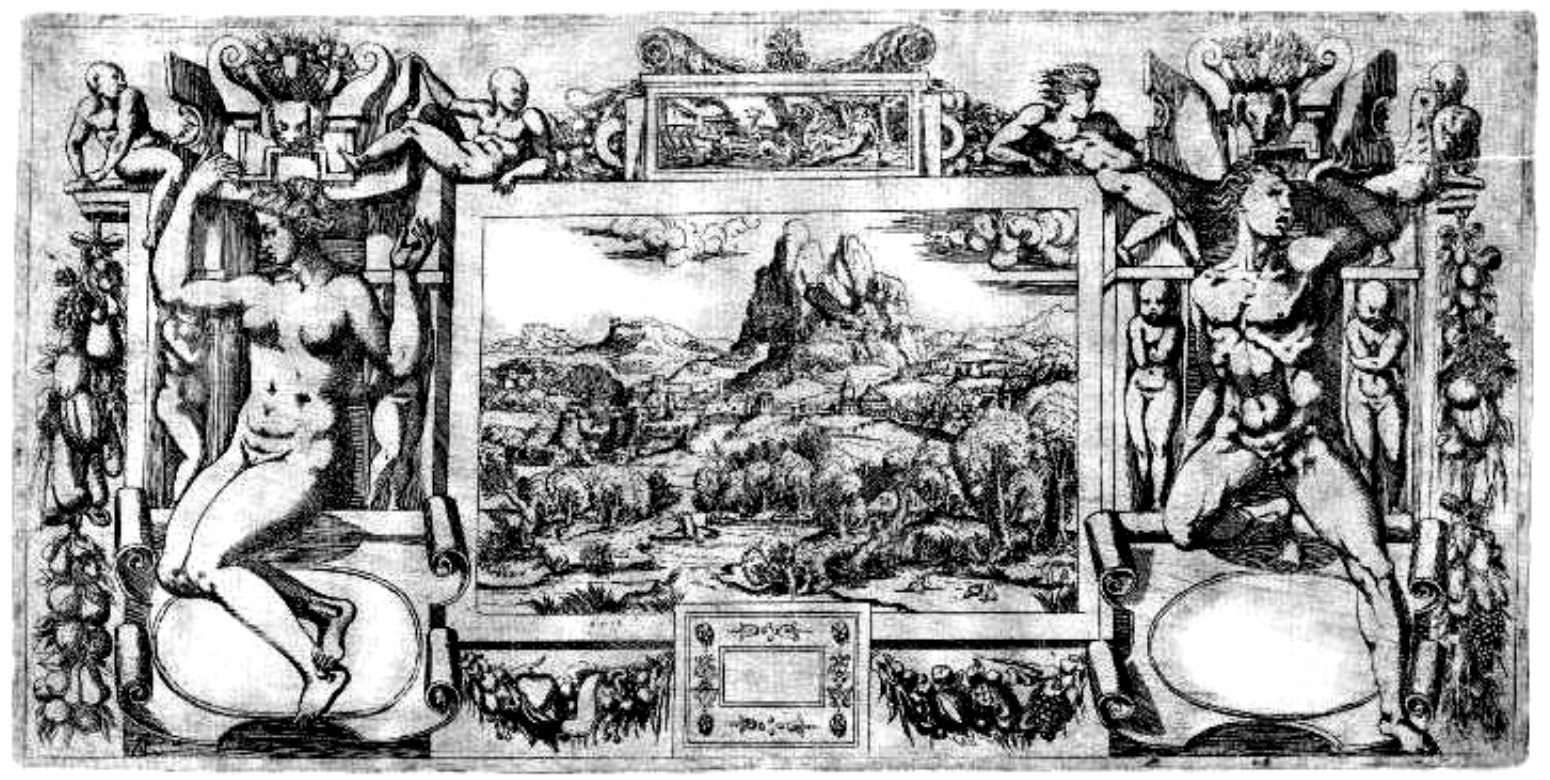

-Antonio Fantucci. Ornamentación con pareja flanqueando un paisaje.Aguafuerte,1543.

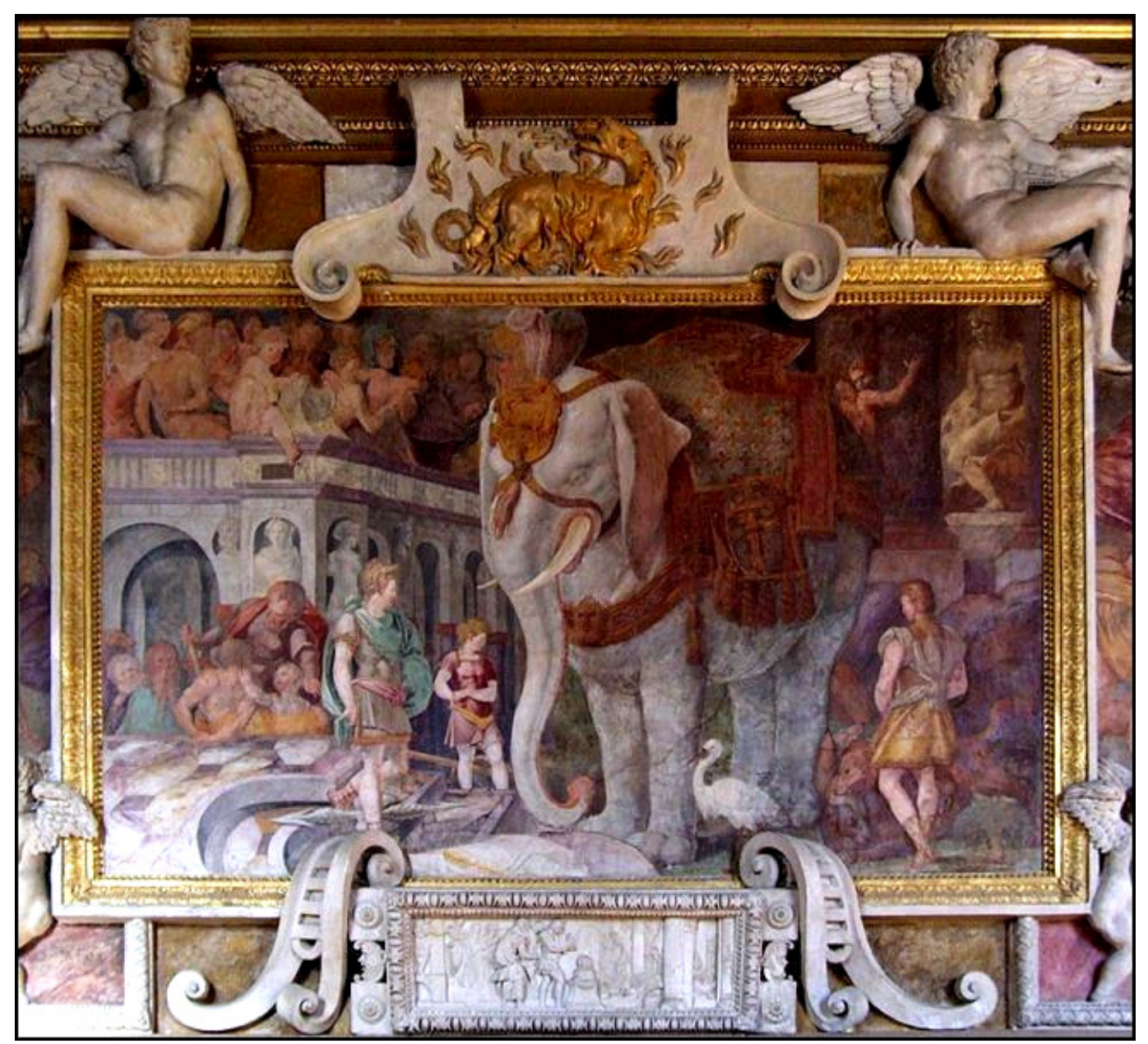

- Rosso Florentino. El elefante Real. Panel de la Galería de Francisco I. 

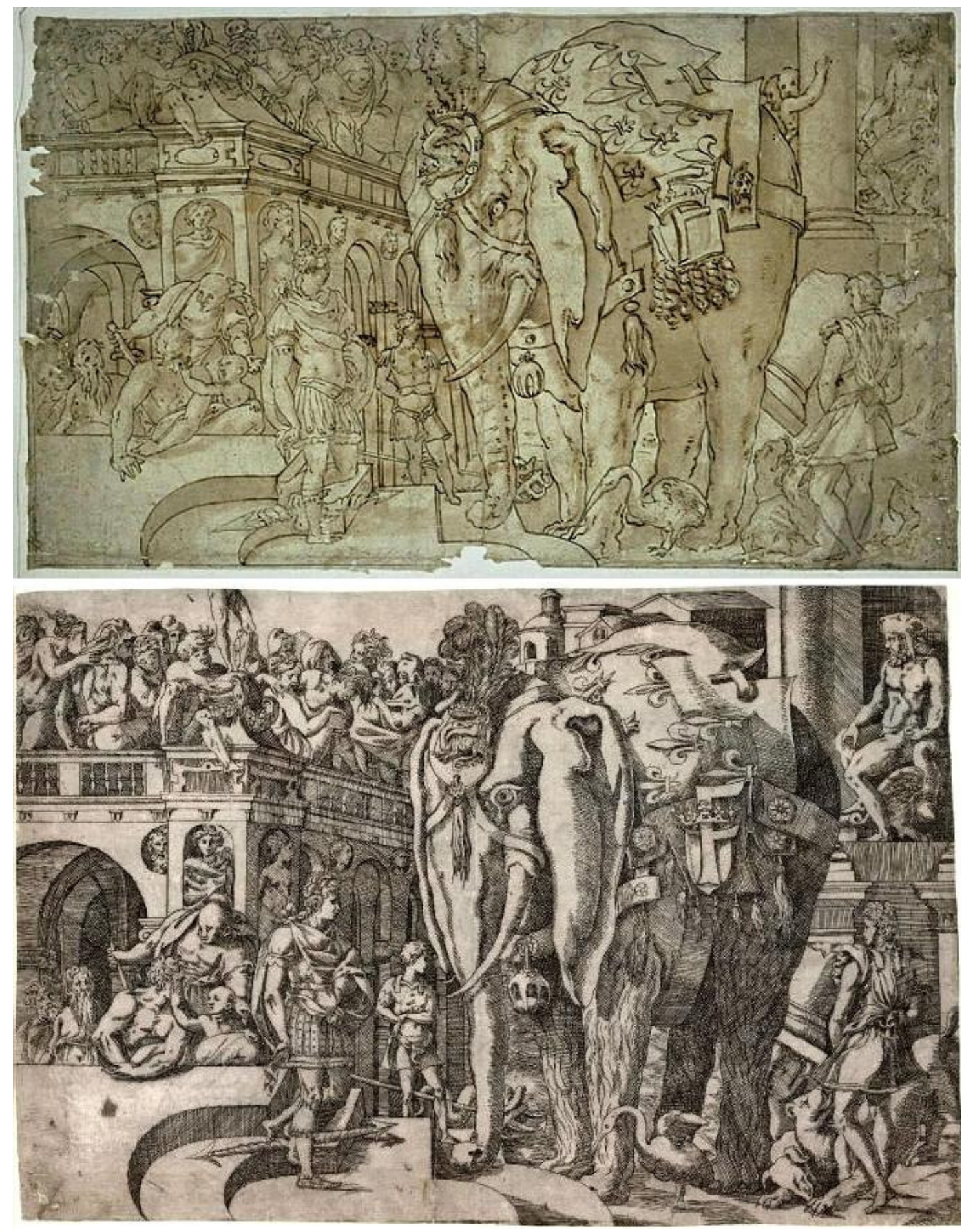

- Rosso, dibujo y Fantuzzi, aguafuerte. El Elefante Real. 1542-45.

Este es uno de los casos en que se conservan la pintura de Rosso, el dibujo que realiza para ser grabado y el aguafuerte de Fantucci. El Elefante Real, llamado así por la gualdrapa con flores de Lis que le cubre, estaría entre las primeras obras de este autor. Sirve como testimonio del hacer del maestro Rosso y de la pericia aún por desarrollar de Antonio Fantucci. 

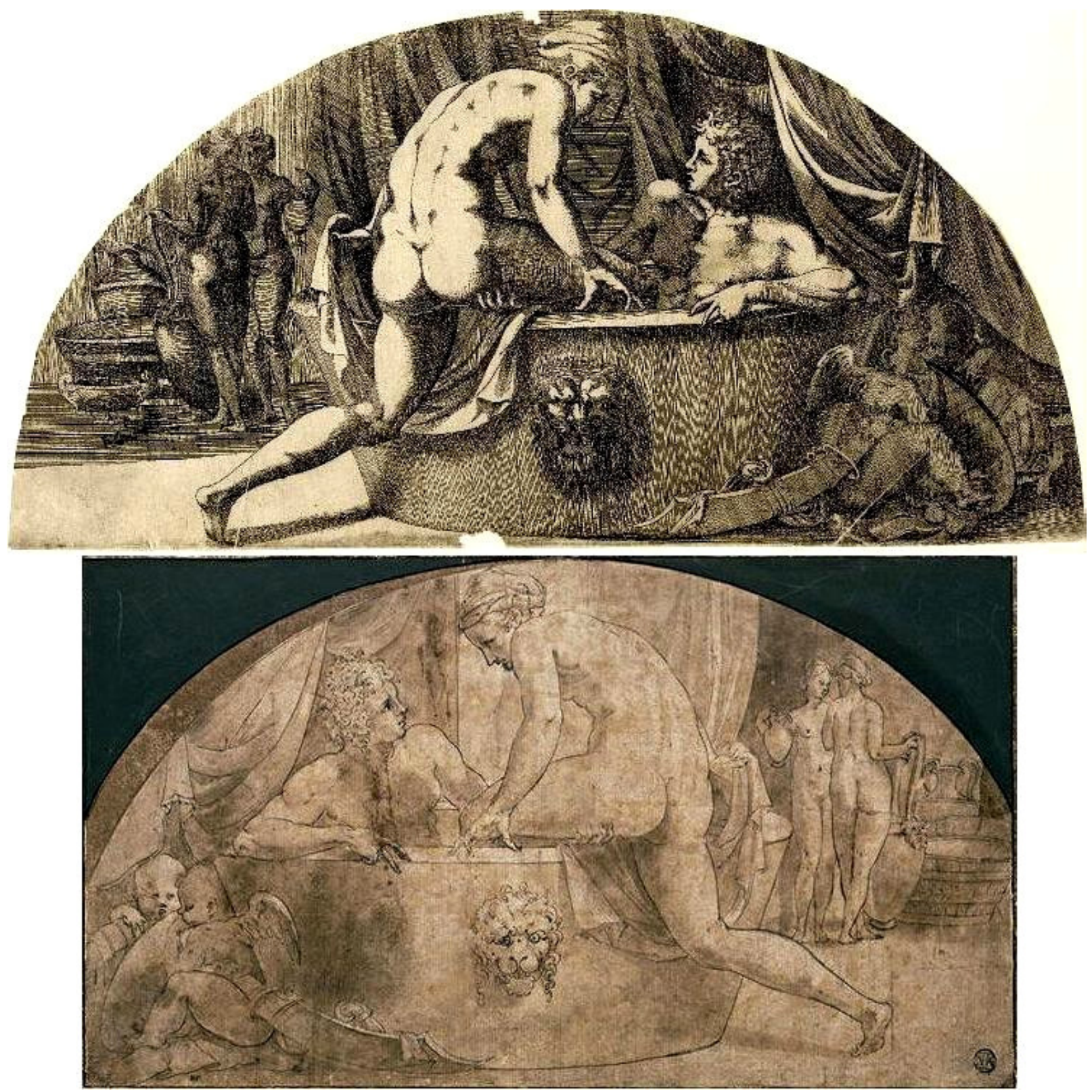

- Fantuzzi, aguafuerte y Primaticcio, dibujo. Venus y Marte en la bañera.1542-45.

Si en lo decorativo y monumental de la obra se rastrea la influencia de Julio Romano, en lo que se refiere a las figuras representadas se configura un estilo que aúna la elasticidad de las figuras de Rosso y el "canon serpentinato" de proporciones alargadas y largo cuello de Parmigianino. Estas normas junto a un revisado romanismo, suavizarían el anticlasicismo visceral del Rosso de sus primeros años y conformarían el de Primaticcio que consolida su estilo en el propio Fontainebleau. Más tarde, Luca Penni, florentino de formación romana, asume y desarrolla esta simbiosis manierista sin dificultad alguna. Las estampas dependientes de este estilo característico servirán para difundirlo directamente $o$ a través de los editores que trabajaron con ellas, en París, Roma o los Paises Bajos y de ahí al resto de Europa.

A partir de 1543 Fantucci afinará su estilo usando tramas de líneas más densas y mordidas regulares y profundas. 


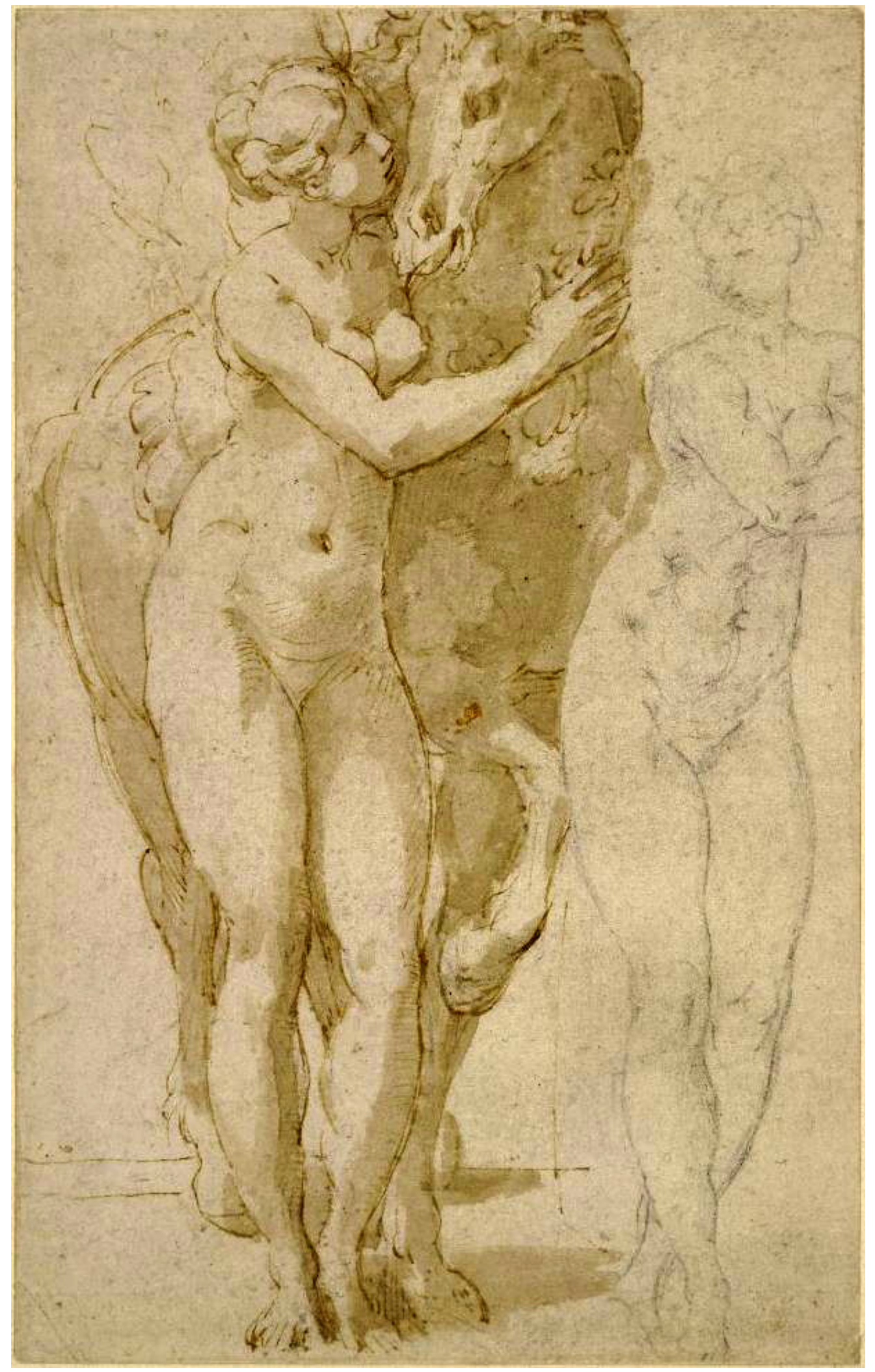

- Parmigianino. Saturno y Filira. Dibujo.

La adopción del canon femenino representado en la obra de Parmigianino, será una de las señas de identidad de la Escuela de Fontainebleau. 

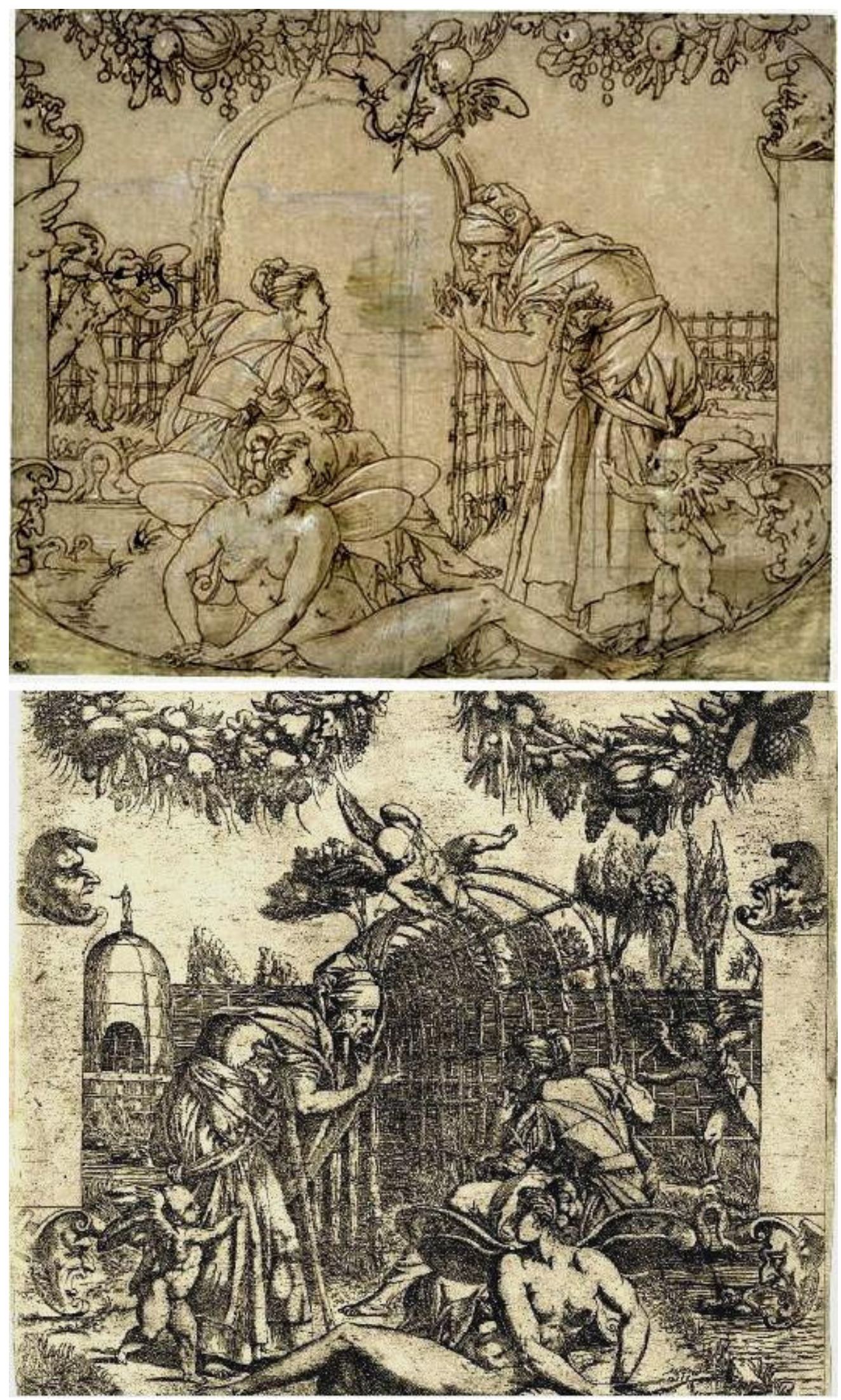

- Rosso, dibujo y Fantuzzi, aguafuerte. 1543-44. Vertumno vestido de anciana visita a Pomona en su huerto. 


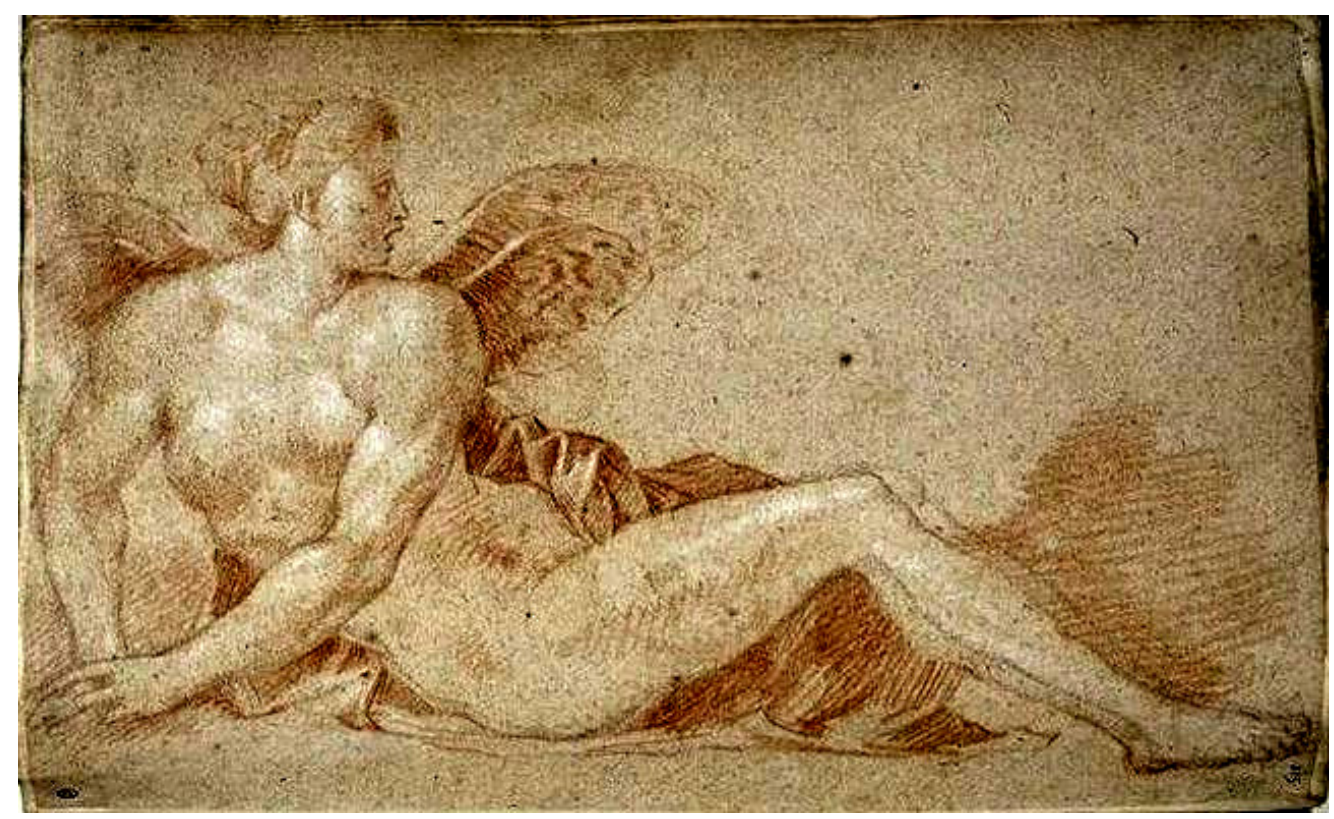

- Rosso Florentino. Ninfa alada. Dibujo.

Antonio Fantucci deja prácticamente de grabar en 1545. En su última etapa, más dependiente e influenciada por Primaticcio, su técnica se aligera y en consecuencia los resultados son más aéreos. Como creador de ornamentaciones y principal ayudante del organizador del vasto programa, su estatus en el rango de trabajadores llega hasta el nivel mayor, solo por detrás de los pintores oficiales. En estos tiempos es muy probable que sus aguafuertes representando paneles decorativos estén realizados según dibujos propios.

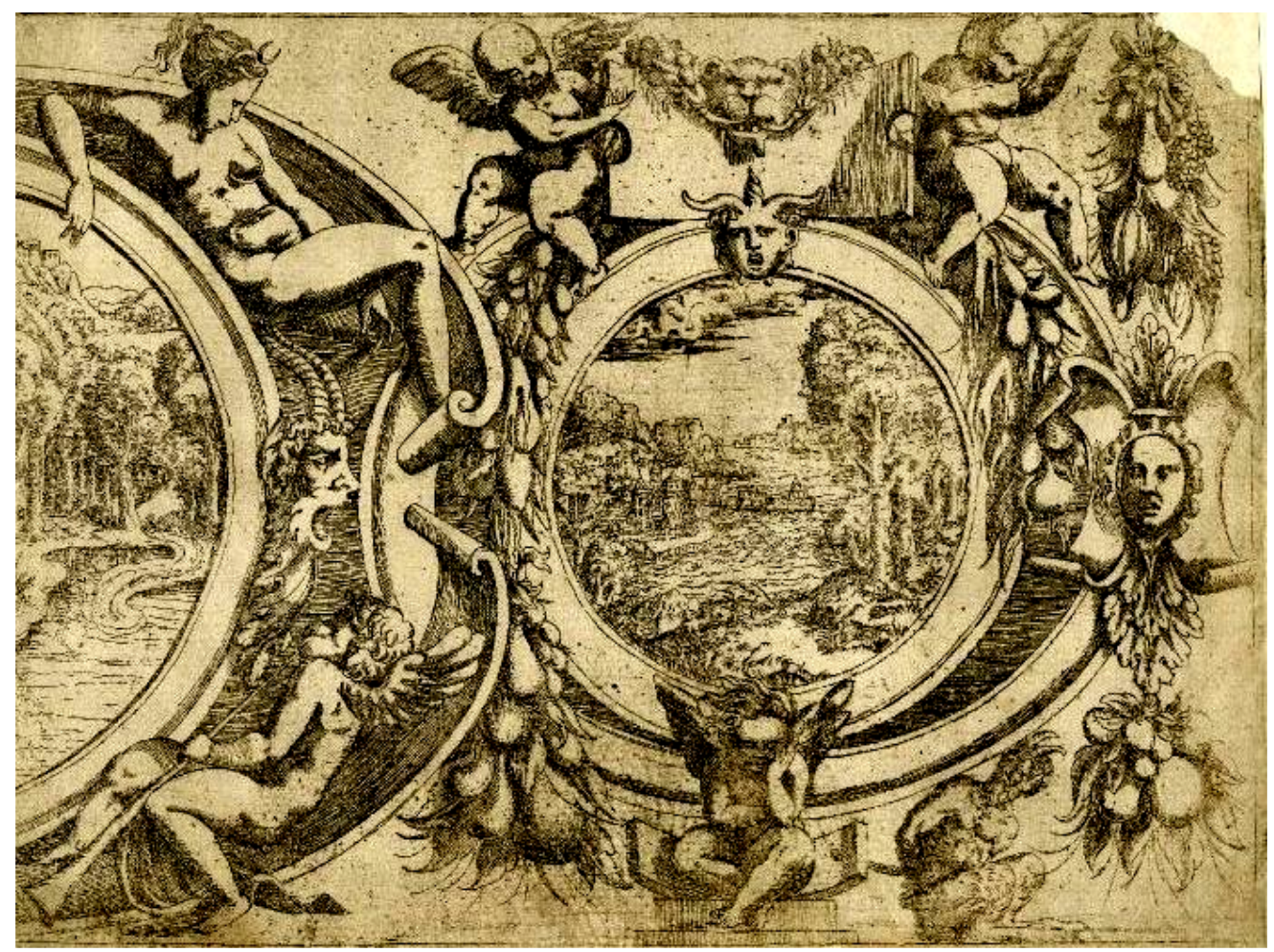

- Antonio Fantuzzi. Ornamento. Aguafuerte. 1543-44. 
Sabemos que como estuquista trabajó en la galería de Ulises y en la de Pomona, ambas perdidas y de ellas nos ofrece testimonio en sus grabados. Salvo algunas estampas firmadas con su nombre completo, suele usar el monograma ANT.F. y en raras ocasiones también incluye en la plancha la fecha de ejecución.

Cuando en sus grabados sobre paneles decorativos el cartucho central aparece vacío, es porque este es de pequeño tamaño o porque en los tiempos finales de su producción el éxito alcanzado por estas imágenes justifica el tema ornamental por si mismo. Pero en aquellos aguafuertes en los que el cartucho central es de grandes dimensiones, el gran espacio blanco central aparece ocupado con paisajes. Los ornamentos reproducidos no albergaban estos mismos motivos, muchos de ellos contenían composiciones que Fantuzzi grabó en planchas independientes y los paisajes representados no se corresponden a los que conocemos de Léonard Thiry. Parece que la introducción de estos paisajes se debe únicamente a su invención y que de este modo inauguró un género de gran pujanza en las artes decorativas francesas a partir de mediados del siglo XVI.

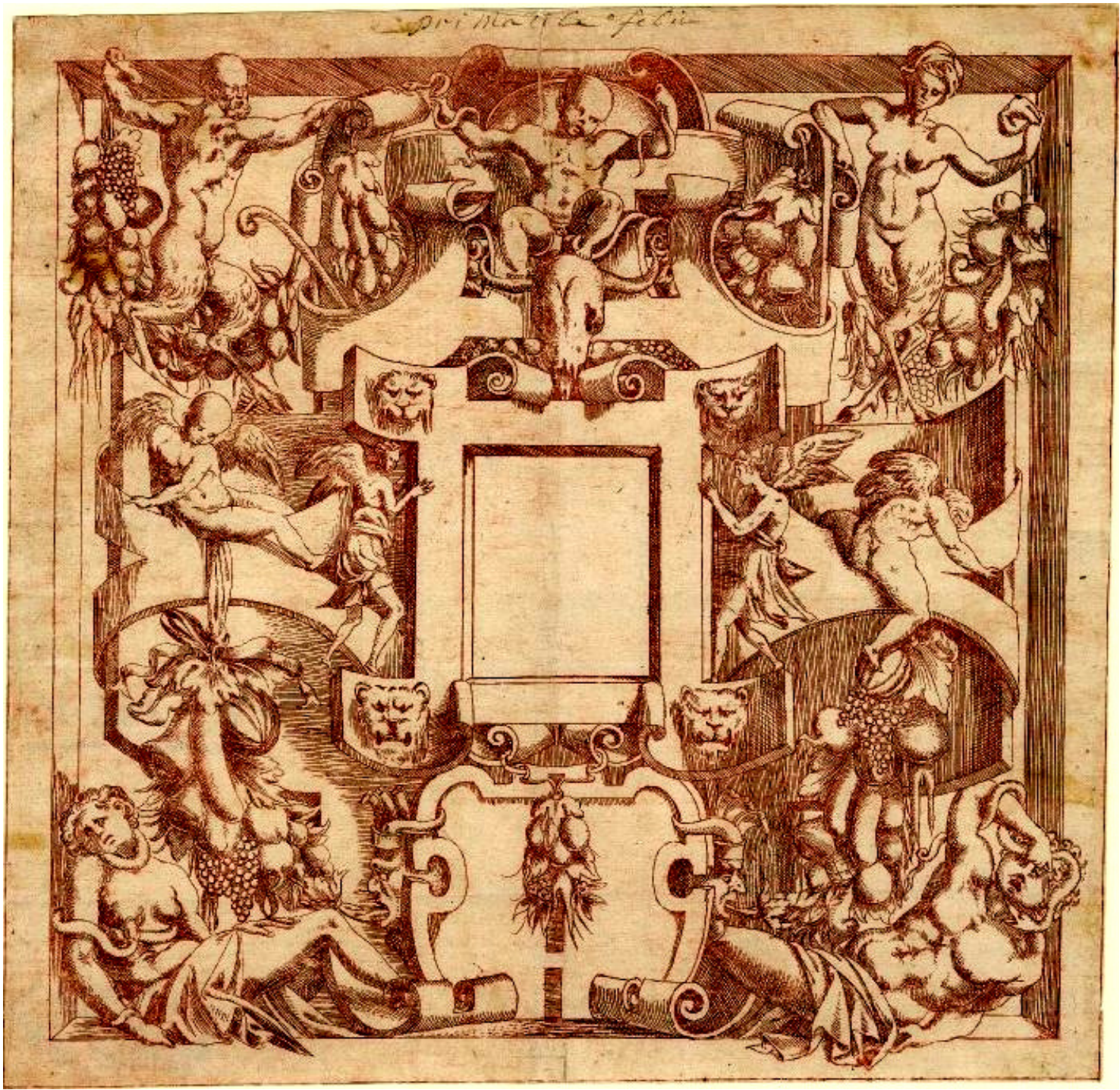

-Antonio Fantuzzi. Ornamento quizás siguiendo un dibujo propio. Aguafuerte. 1543-44 
Antonio Fantuzzi está en estos momentos grabando motivos propios y ajenos, a veces dentro de una misma plancha. Encontramos así uno de los ejemplos más destacados de colaboración creativa en gráfica, reflejo fiel de lo que se está produciendo en su entorno.

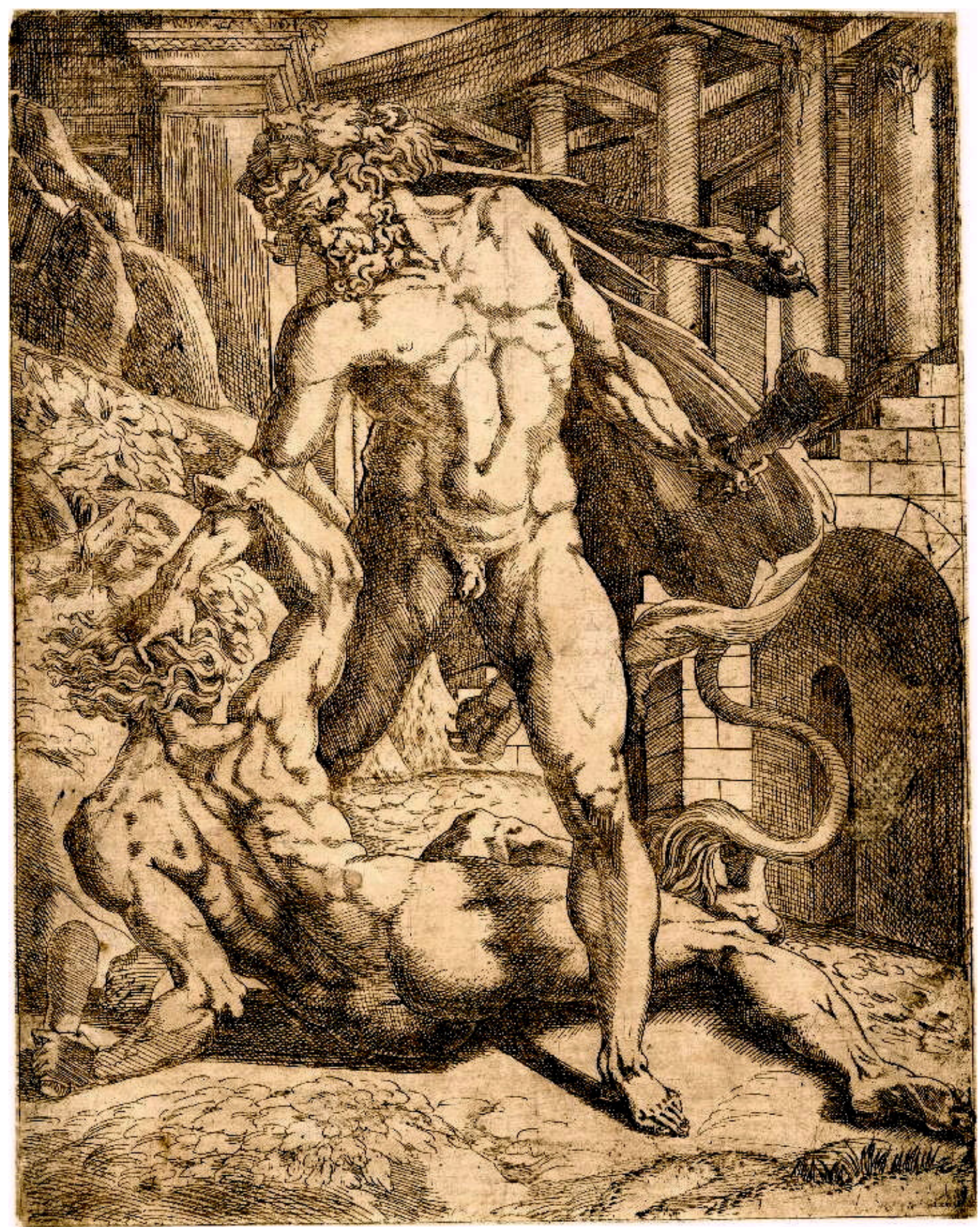

- Antonio Fantucci según Rosso. Hércules y Anteo. Aguafuerte. 1543-44. 


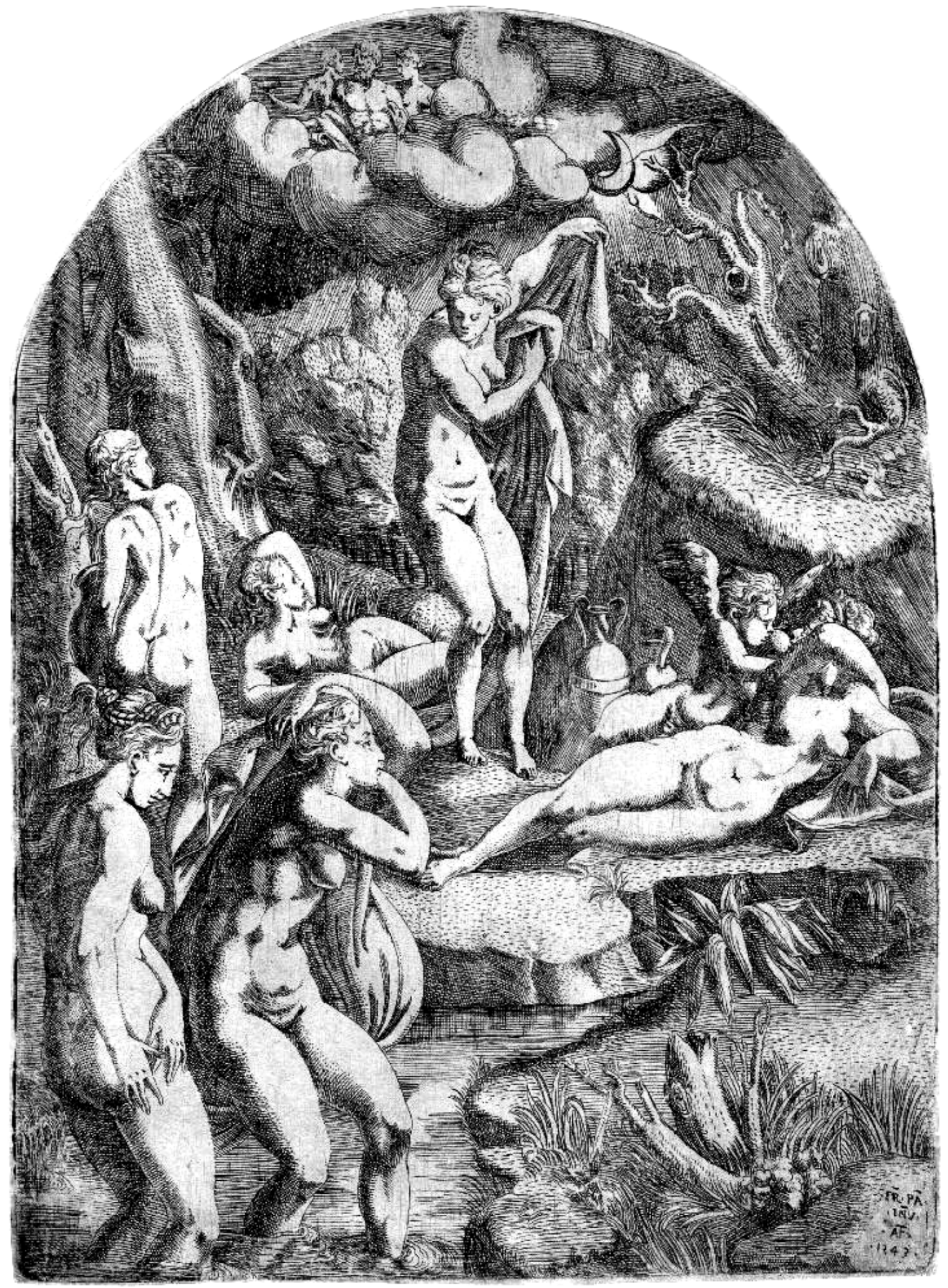

- Fantuzzi según Parmigianino. El baño de Venus y las ninfas. Aguafuerte. 1543. 

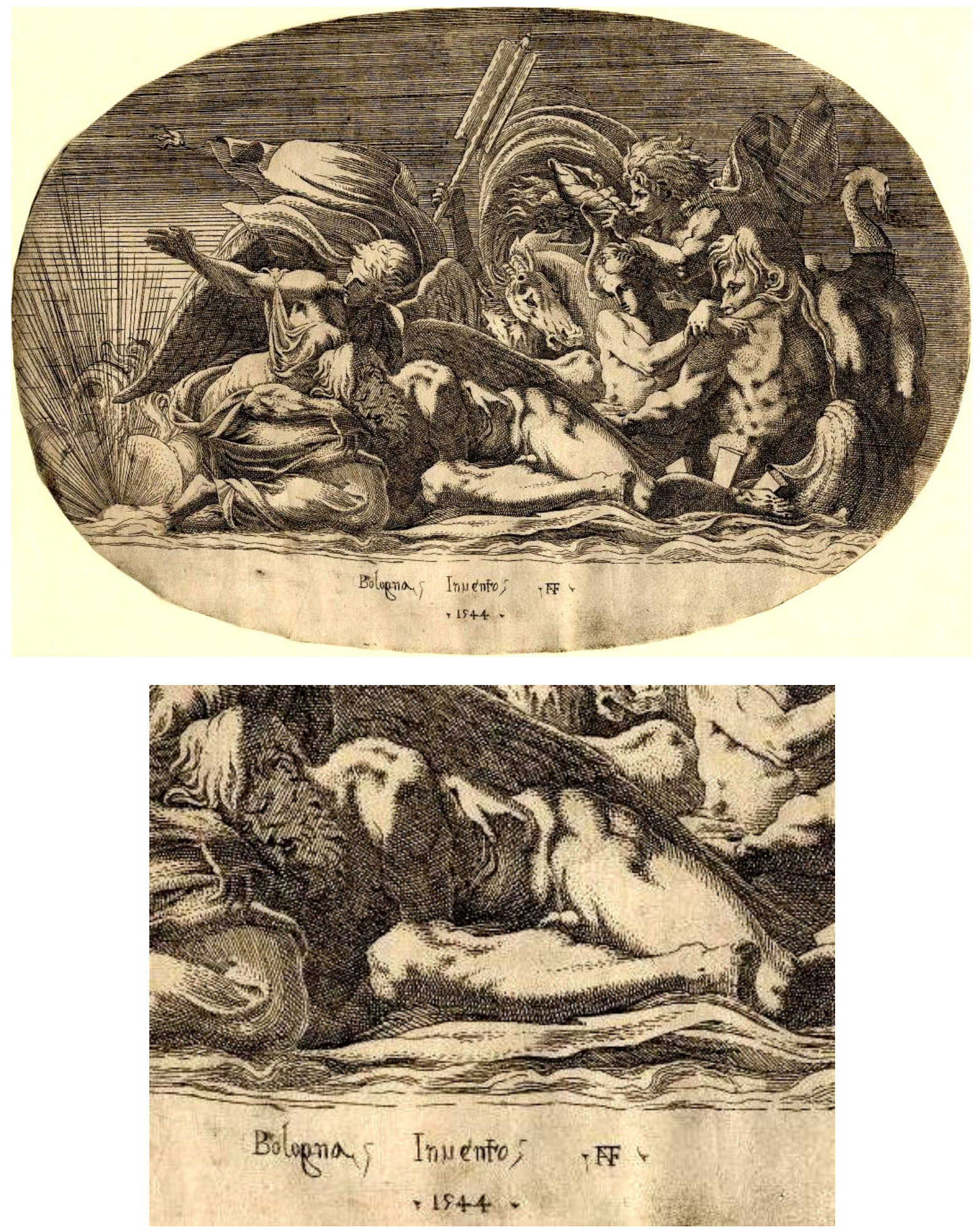

- Antonio Fantuzzi según Primaticcio. Cronos y Poseidón y detalle de la figura de Cronos con firma y fecha. Aguafuerte. 1544.

El notable progreso técnico se aprecia en la mayor seguridad en el manejo de la punta y en la utilización de pequeños trazos y punteados para definir transiciones tonales. El resultado de los trabajos últimos confirma la consolidación de Fantuzzi y su consagración como uno de los grabadores fundamentales de la escuela. 


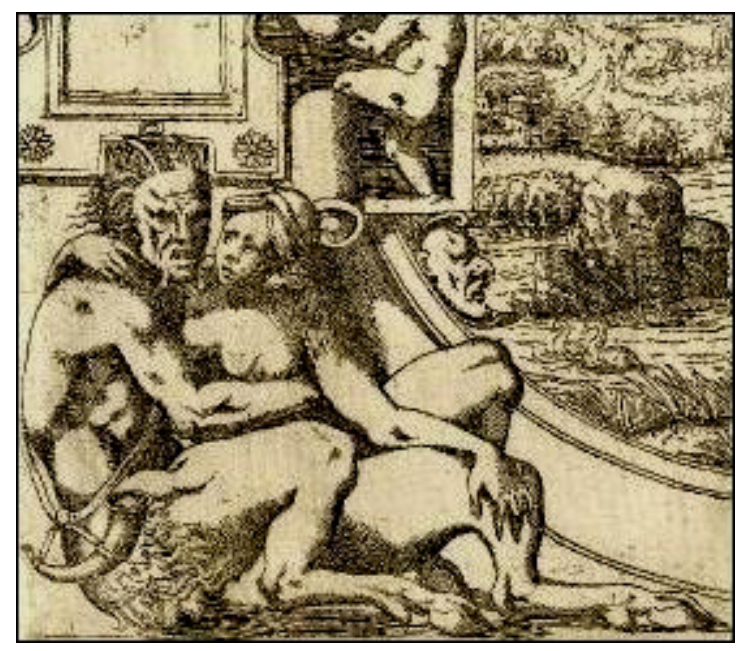

- Antonio Fantuzzi. Panel ornamental, fauno y ninfa. Detalle 1543.

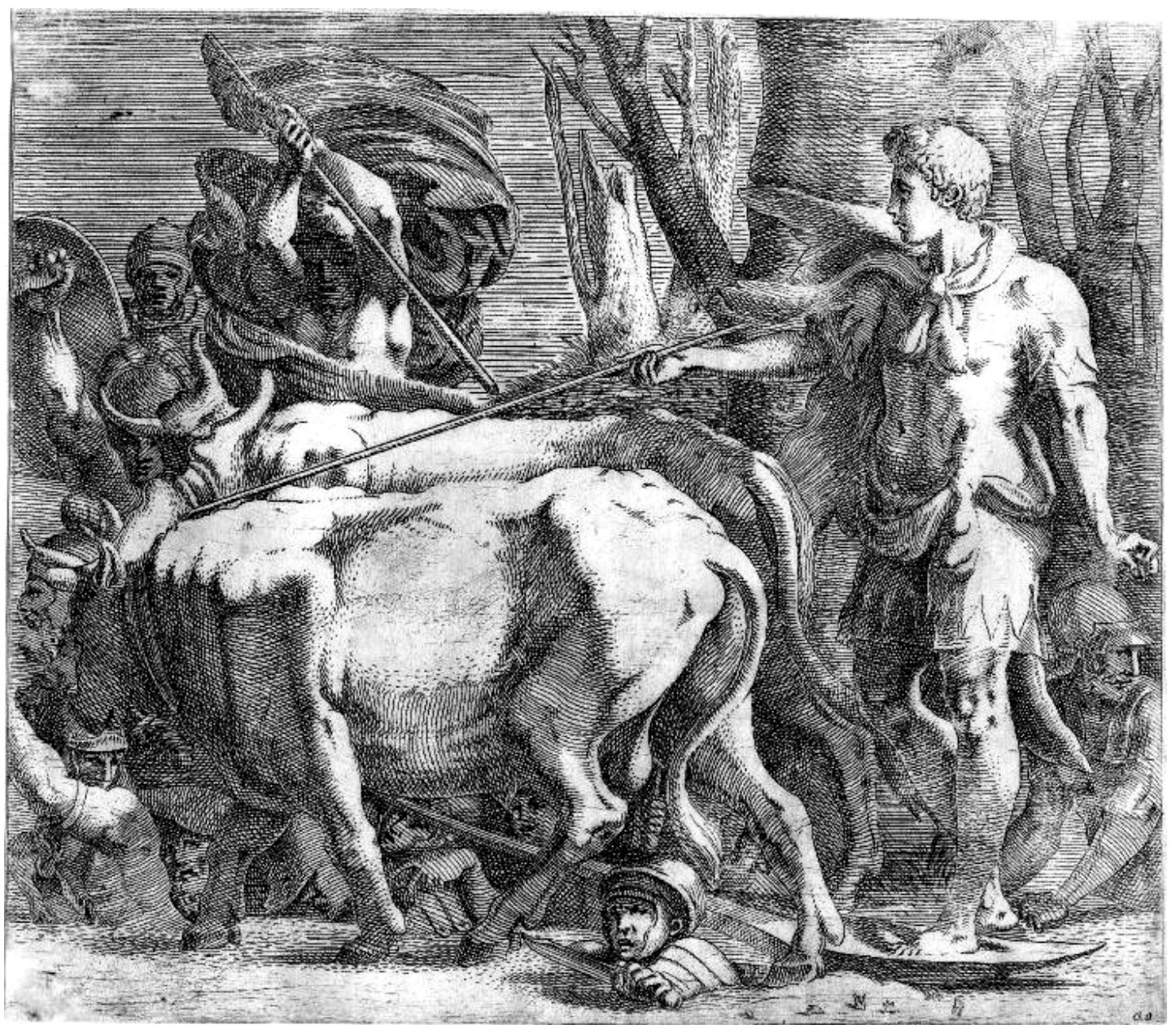

- Fantucci según Primaticcio. Guerrero arando un campo de batalla. Aguafuerte.1544. 


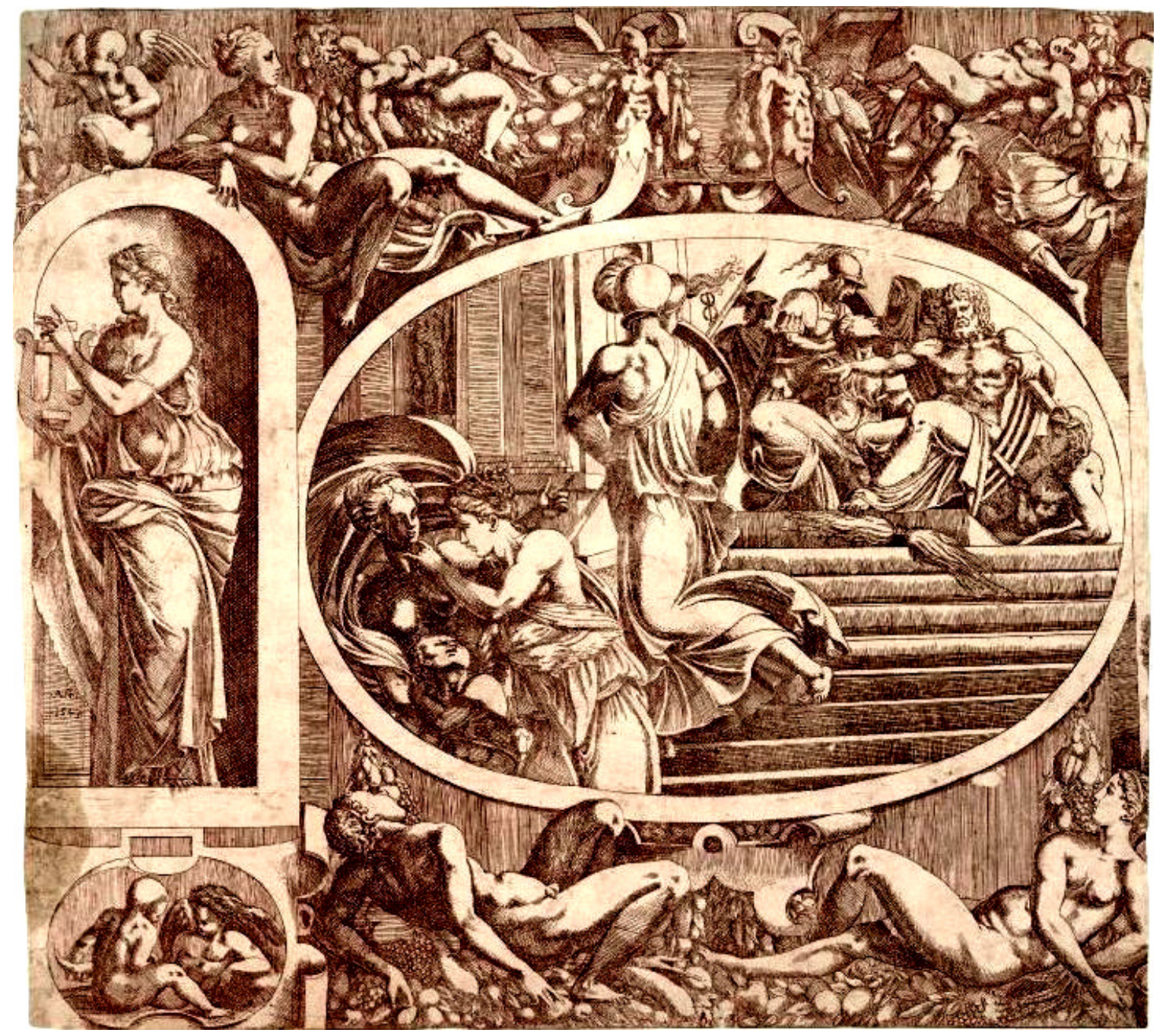

- Antonio Fantuzzi según Primaticcio. Júpiter enviando a Juno, Venus y Minerva al juicio de París. Aguafuerte. 1544.

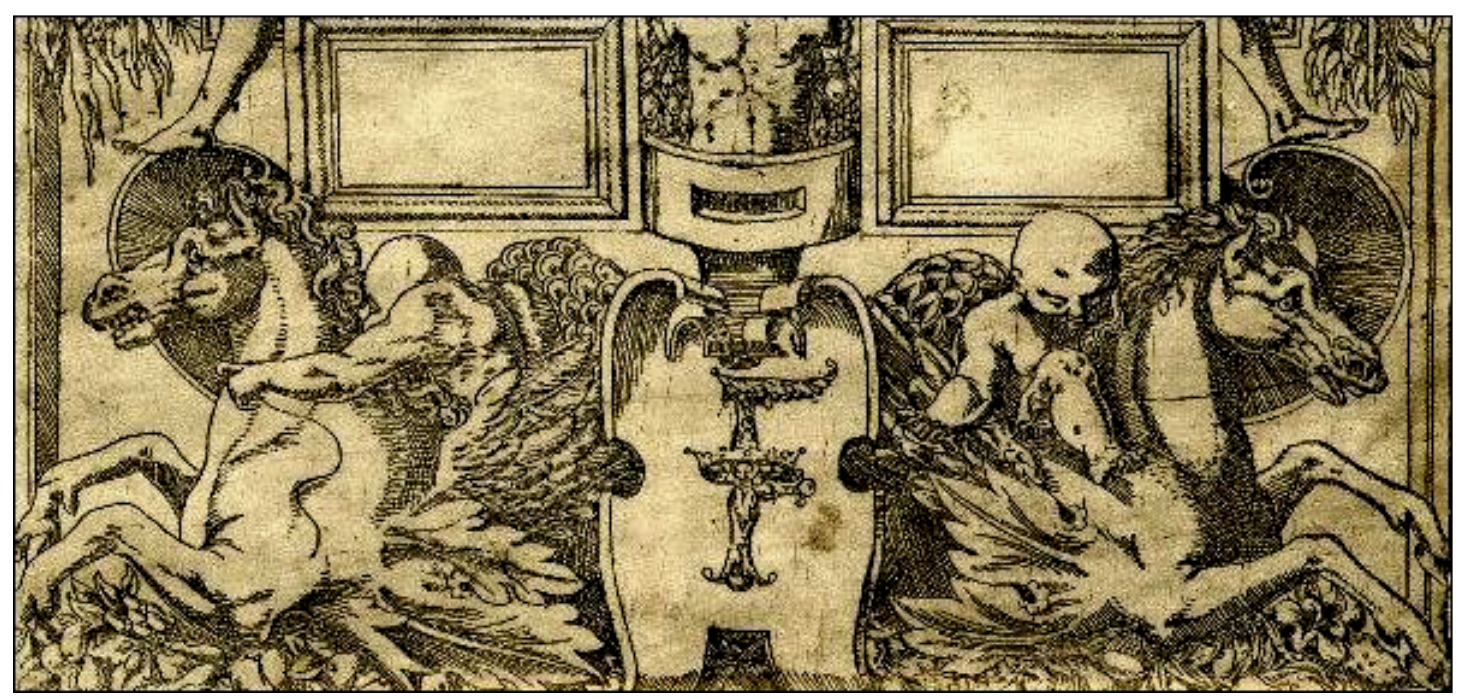

- Fantuzzi.Ornamento con Pegasos. 1543-44. 


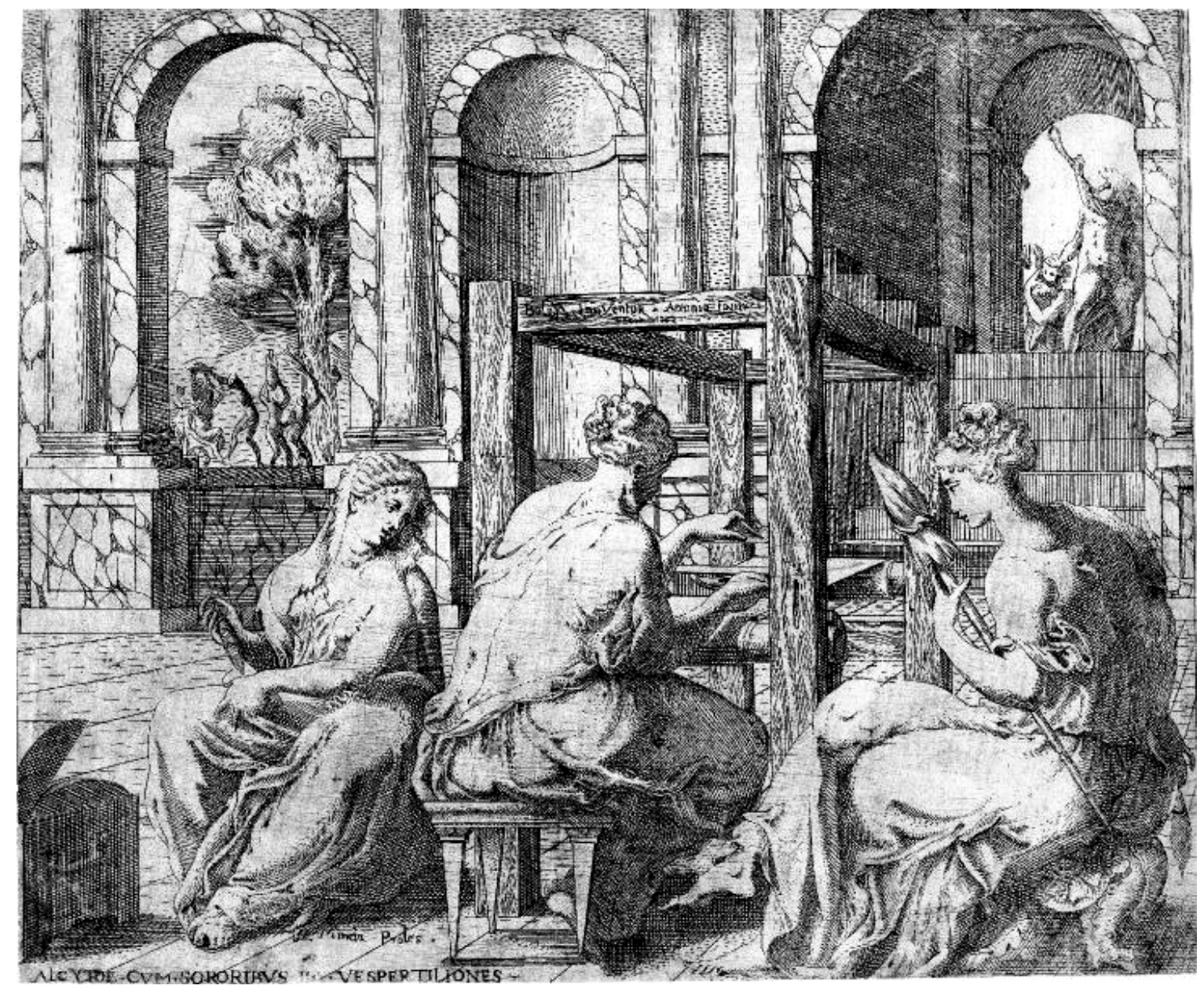

- Antonio Fantucci según Primaticcio. Las hijas de Mineo tejiendo con bacanal en el exterior. Aguafuerte. 1545.

Fantucci es el grabador arquetípico y mejor ejemplo de lo que fueron los miembros de esta escuela. Multidisciplinar y en constante evolución, su obra gráfica algo negligente en la realización técnica, se corresponde con el eclecticismo resultante de todas las influencias que conformaron Fontainebleau.

Léon Davent. Apenas se sabe nada sobre la biografía de este miembro de la escuela de grabado . Conocido como Maestro L.D. por las iniciales con las que firmó sus estampas, solo en 1974 Grodecki consiguió identificar su verdadero nombre. Burilista y aguafortista, el grueso de su producción se basa en la obra de Francesco Primaticcio. Hasta su identificación segura, las siglas L.D. dieron pie a numerosas hipótesis. Se dedujo que significarían Luca Delineavit haciendo referencia a Luca Penni, o que la D. podía corresponder al lugar de procedencia, Daventer, del pintor Léonard Thiry. Sus primeras obras, donde prepondera el uso delicado y meticuloso del buril, aparecen en 1540 y su evolución en grabado corre paralela a la de otros miembros del taller. Es muy posible que en el aguafuerte siguiera las enseñanzas de Fantuzzi.

Su obra puede dividirse en dos bloques diferenciados en calidad y temática, lo que aún crea dudas sobre la autoría común de ambos. 


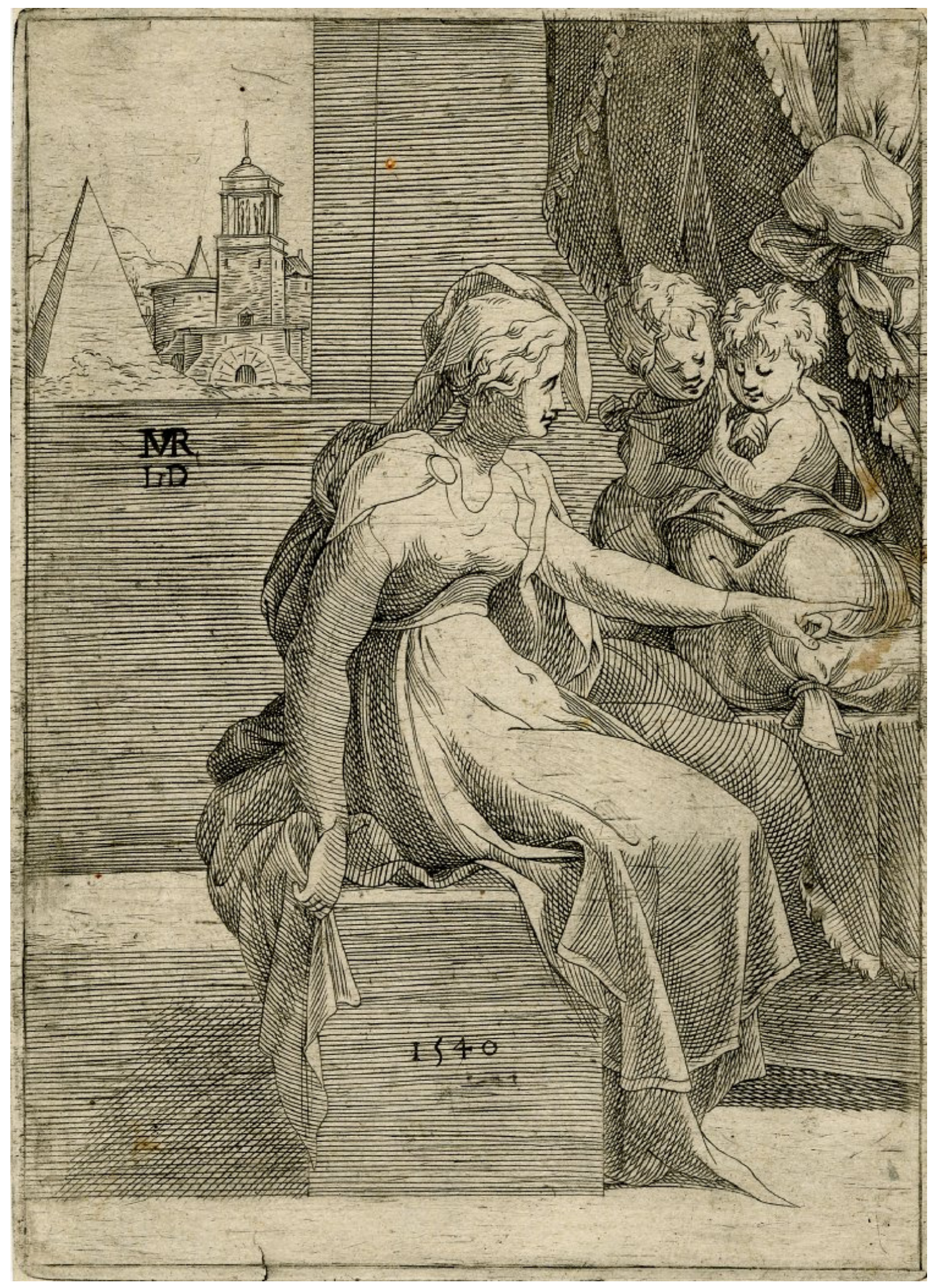

- Léon Davent según Parmigianino. Mujer sentada sobre un pedestal . Buril ca.1540. 


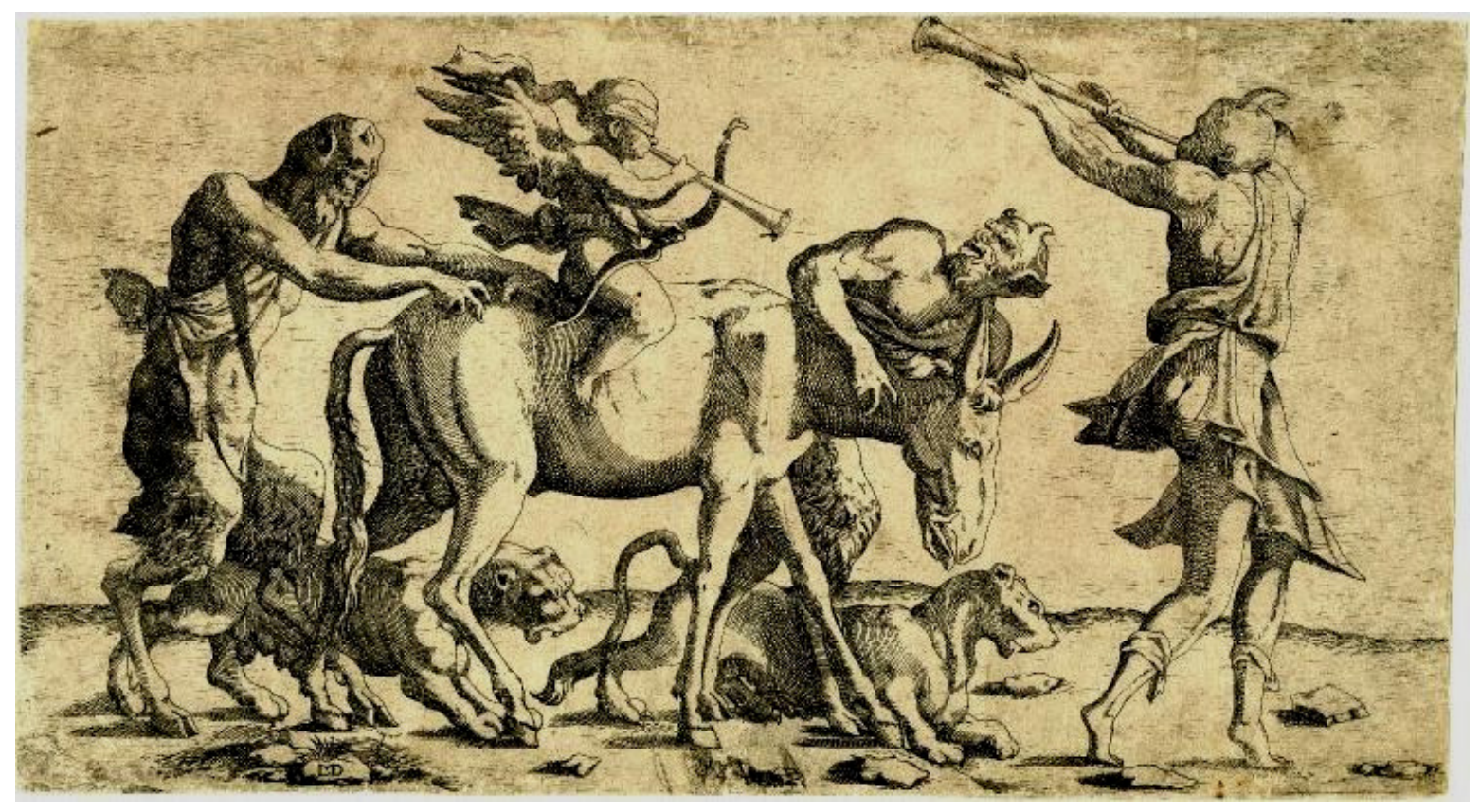

- Léon Davent según Rosso. Cupido, faunos y sátiro en procesión. Buril. ca. 1540.

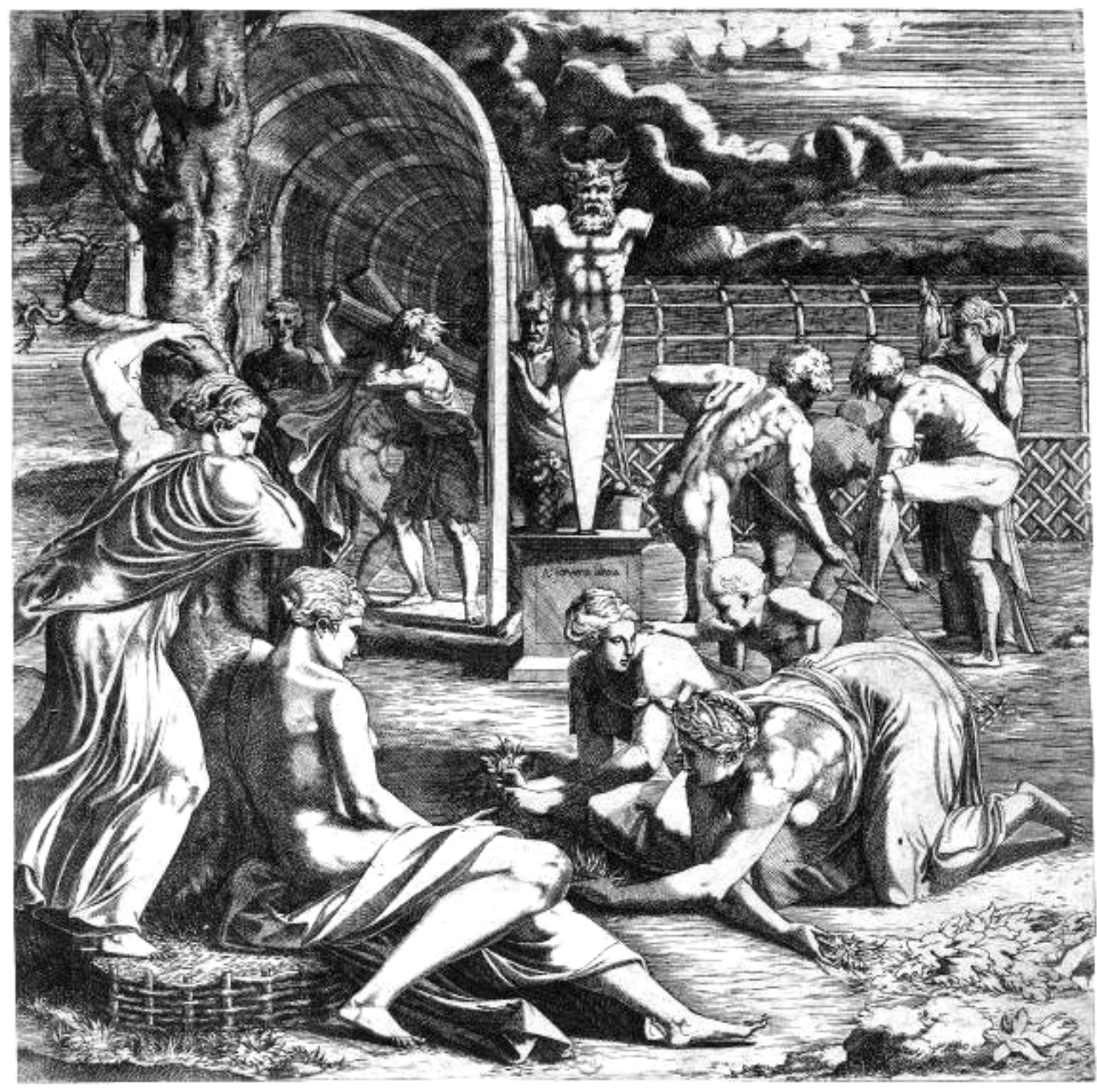

- Léon Davent según Primaticcio. El jardín de Vertumno y Pomona. Buril. 1540-45. 
Avanzando en la década de los 40 y al mismo tiempo que se inicia en la producción de aguafuertes, sus trabajos se muestran más densos y complejos de trazado, se incrementa el interés por la luminosidad y la existencia de algunos problemas de procesado se solventan en la limpieza e impresión. En algunas estampas aparecen zonas parcialmente veladas por pátinas de tinta dejadas a propósito durante el proceso de limpieza y en otras, como en el caso de la serie de diosas y musas, se utiliza una veladura general en toda la imagen para evitar un resultado demasiado lineal.

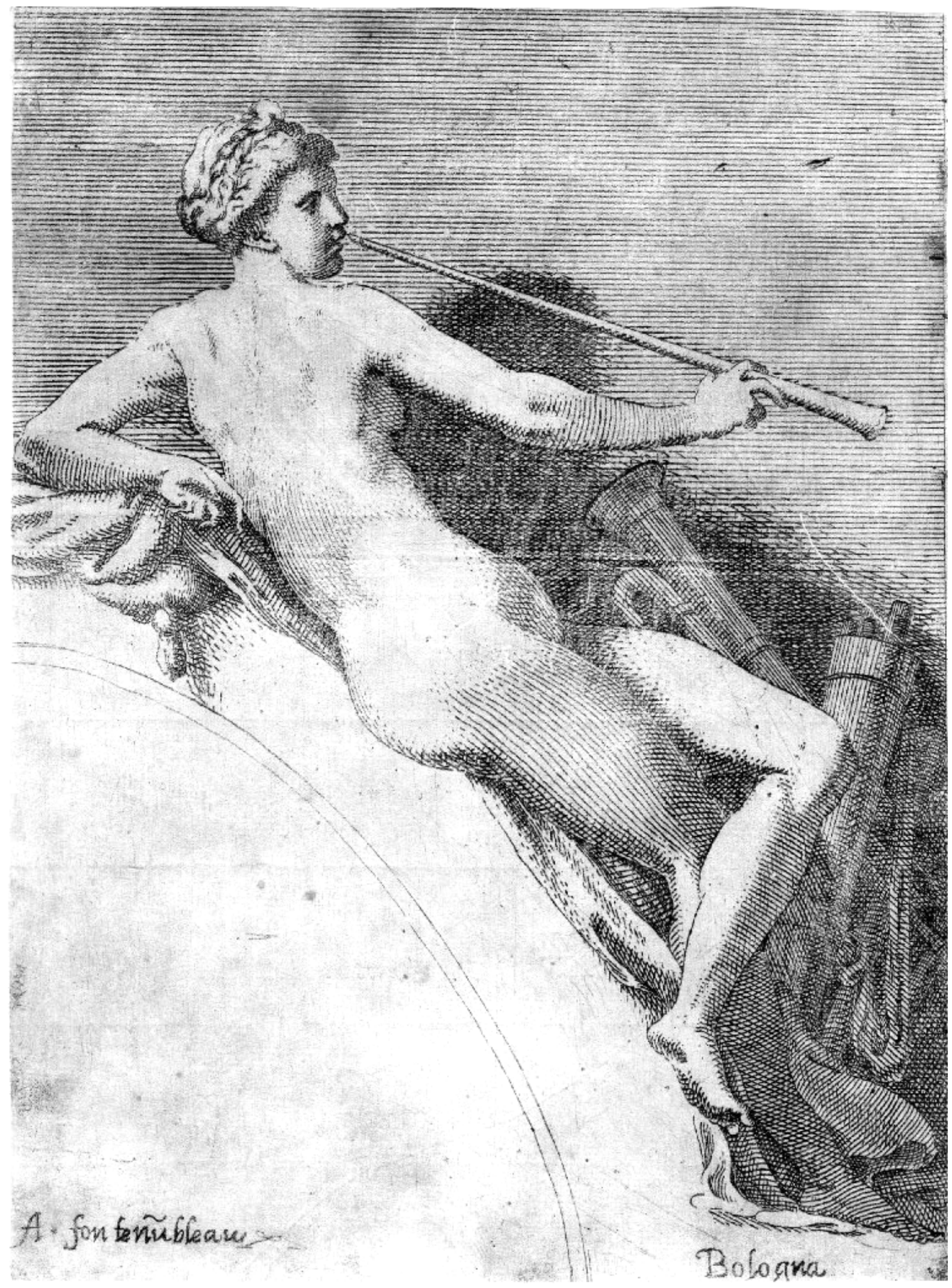

-Léon Davent según Primaticcio. Eutherpe. Aguafuerte. 1540-45. 

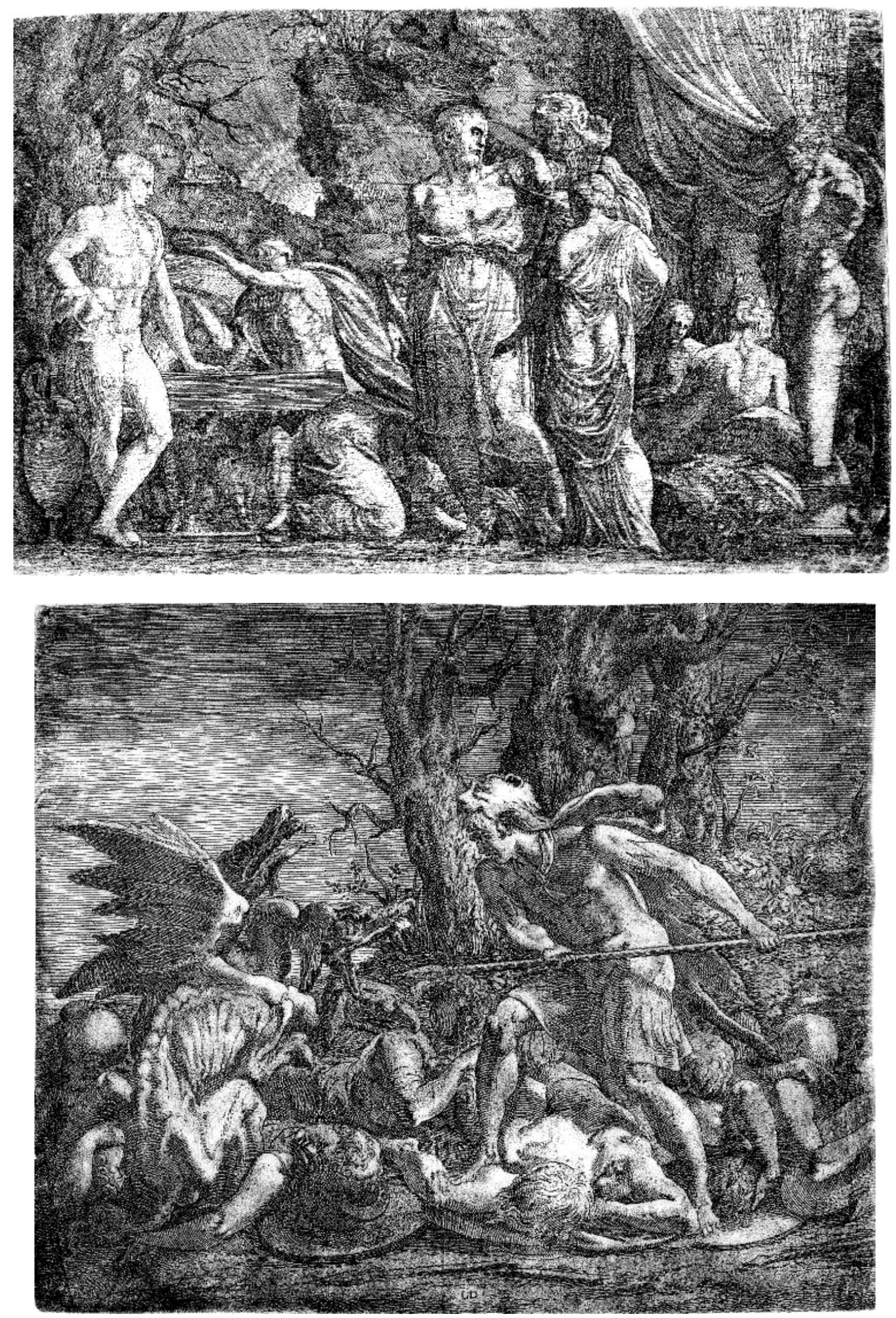

- Léon Davent según Primaticcio. "Hércules y Omfale intercambiando sus vestidos" y "Jasón o Cadmus y el Dragón". Aguafuertes. 1543-44. 


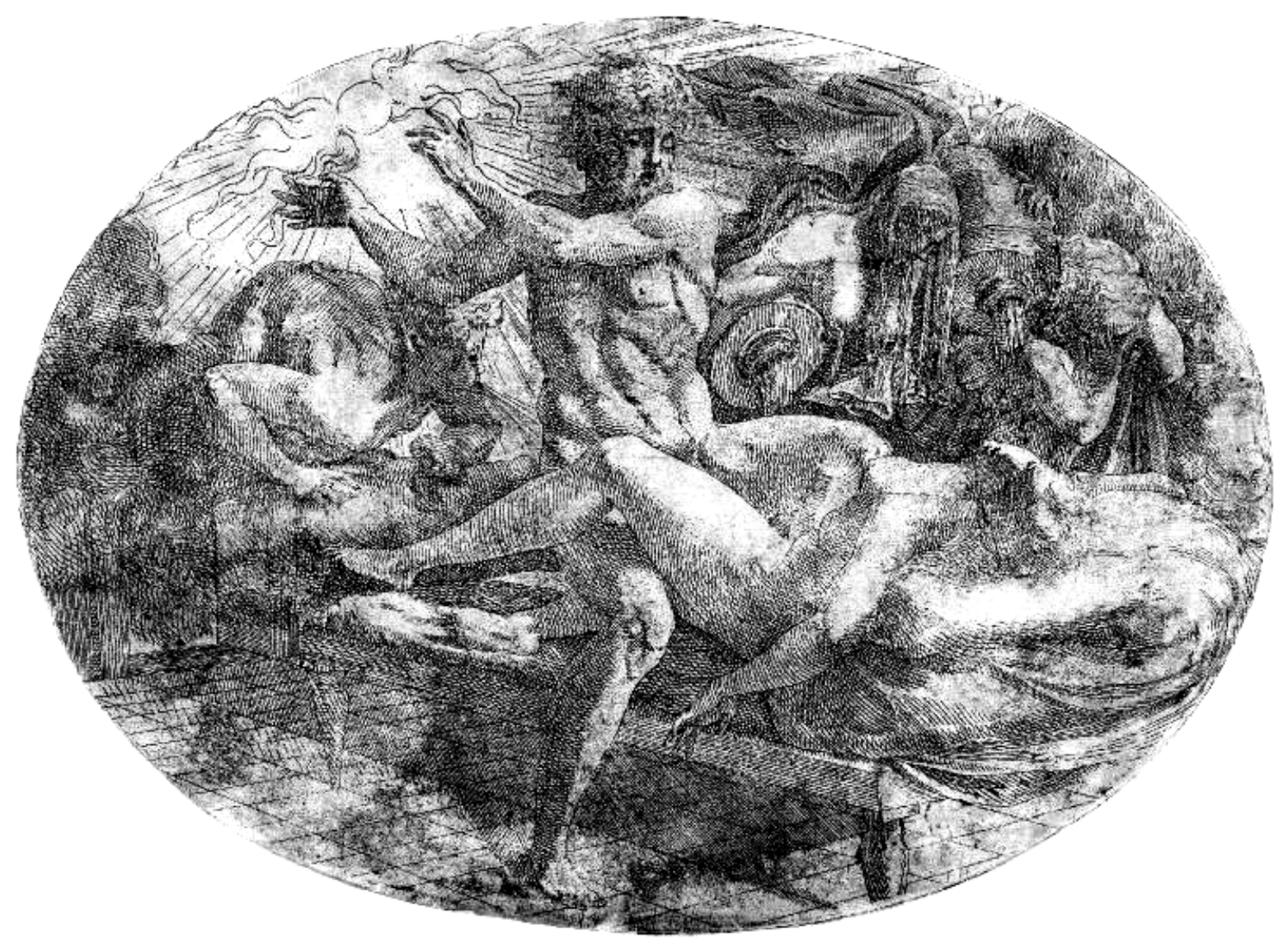

- Léon Davent según Primaticcio. Júpiter y Semele. 1543-44.

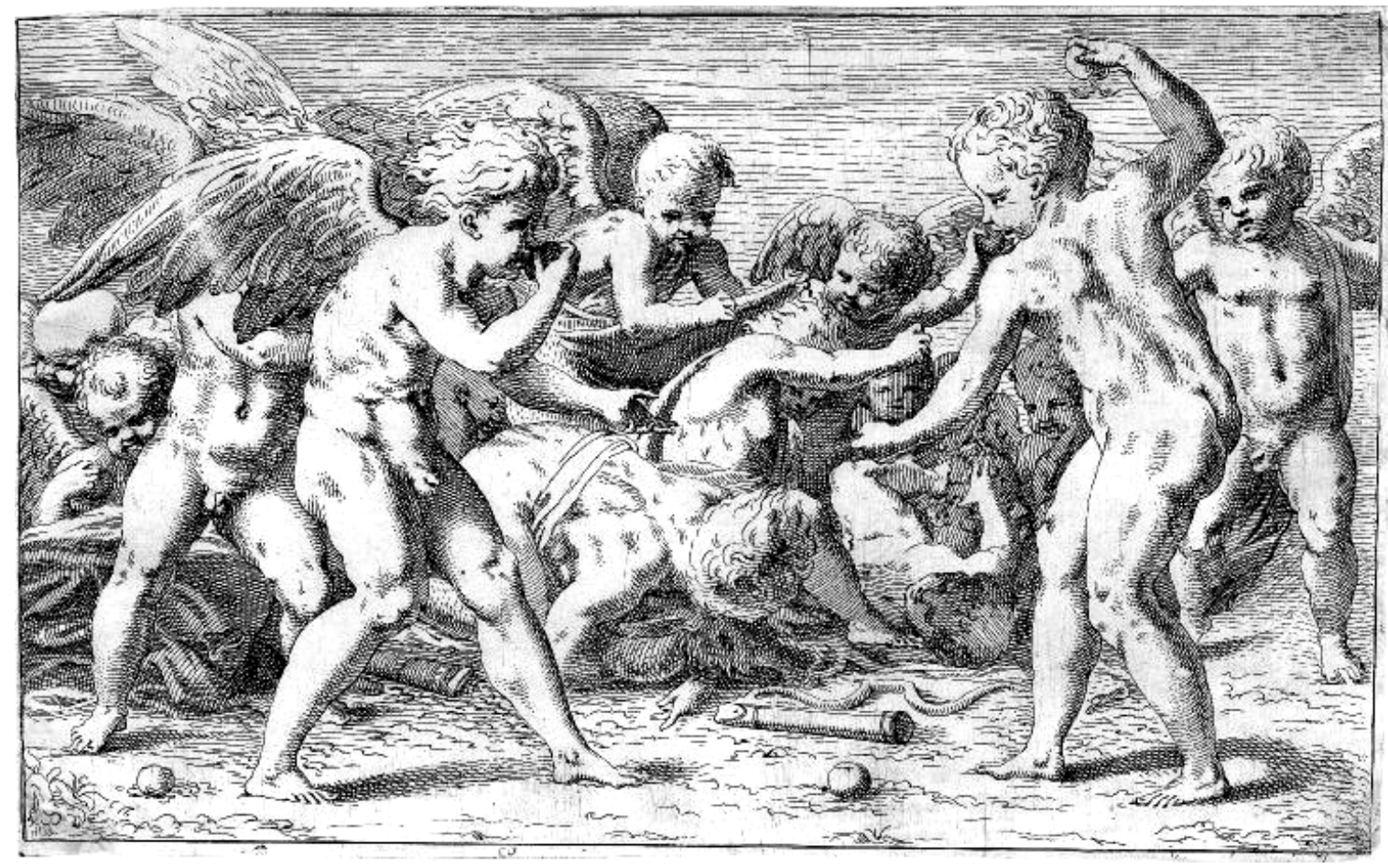

-Léon Davent. Eros y Anteros peleando. Aguafuerte. ca.1545. 
Alrededor de 1545, su forma de trabajar cambia hacia un estilo más simple y conciso, desaparece la densidad de trazado a cambio de una representación a base de líneas más largas y rayados más abiertos. Los mordidos son profundos y las estampaciones limpias. La luz aparece más contrastada y parece interesarse más por las cualidades decorativas de los modelos reproducidos.

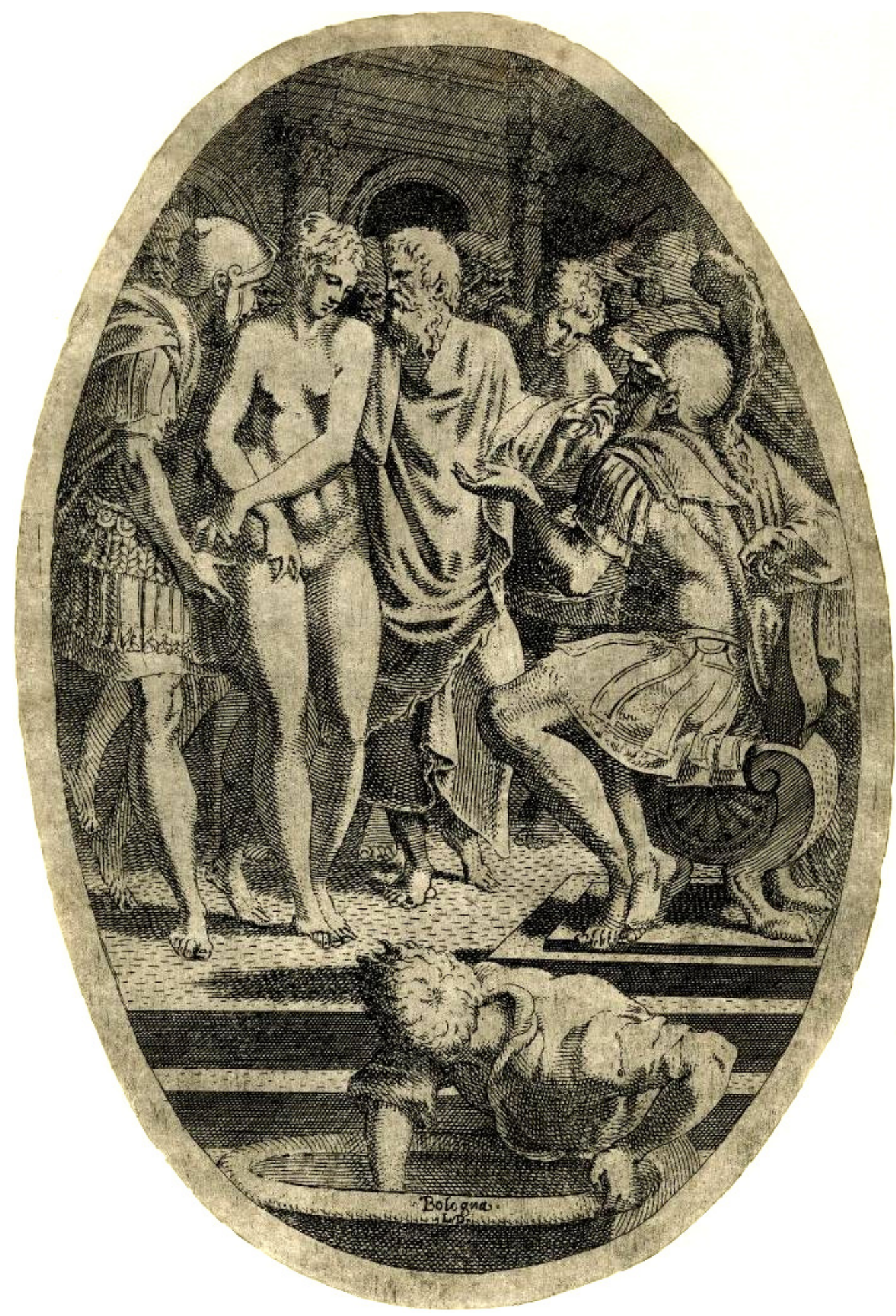

-Léon Davent según Primaticcio. Timoclea ante Alejandro. Aguafuerte 1545-46. 


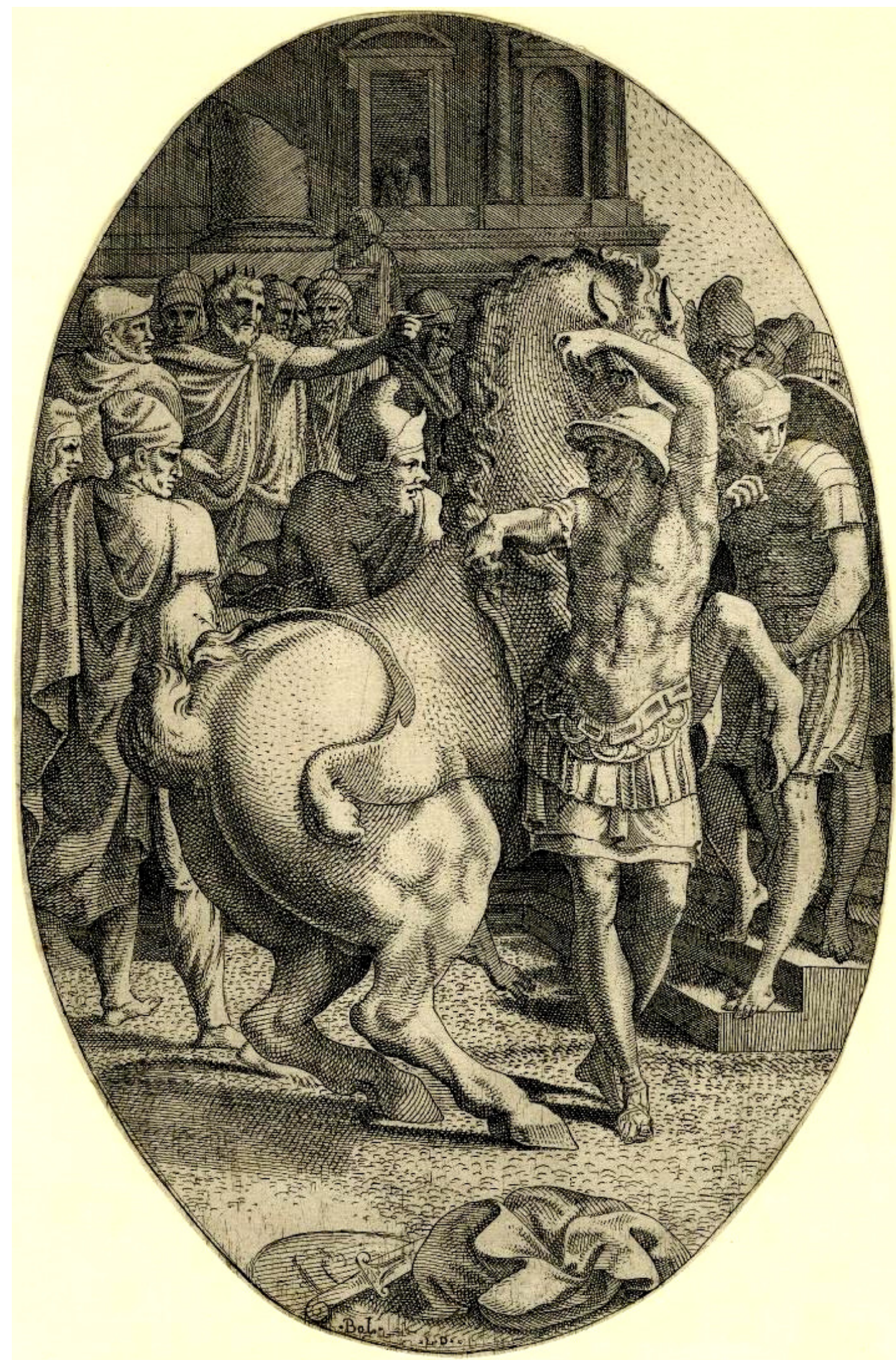

- Léon Davent según Primaticcio. Alejandro domando a Bucéfalo. Aguafuerte. 1545-47. 

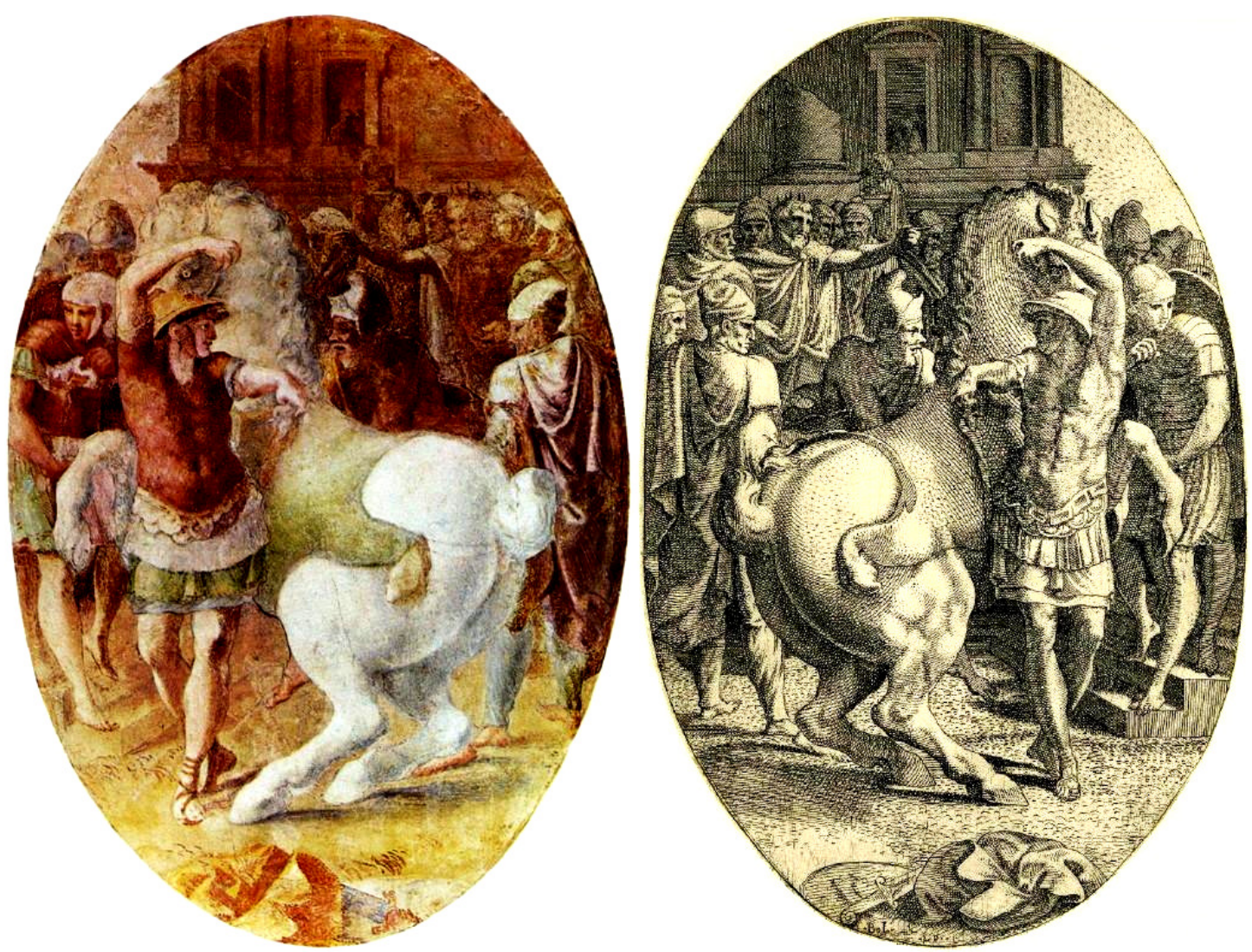

- Primaticcio, fresco y Davent,aguafuerte.

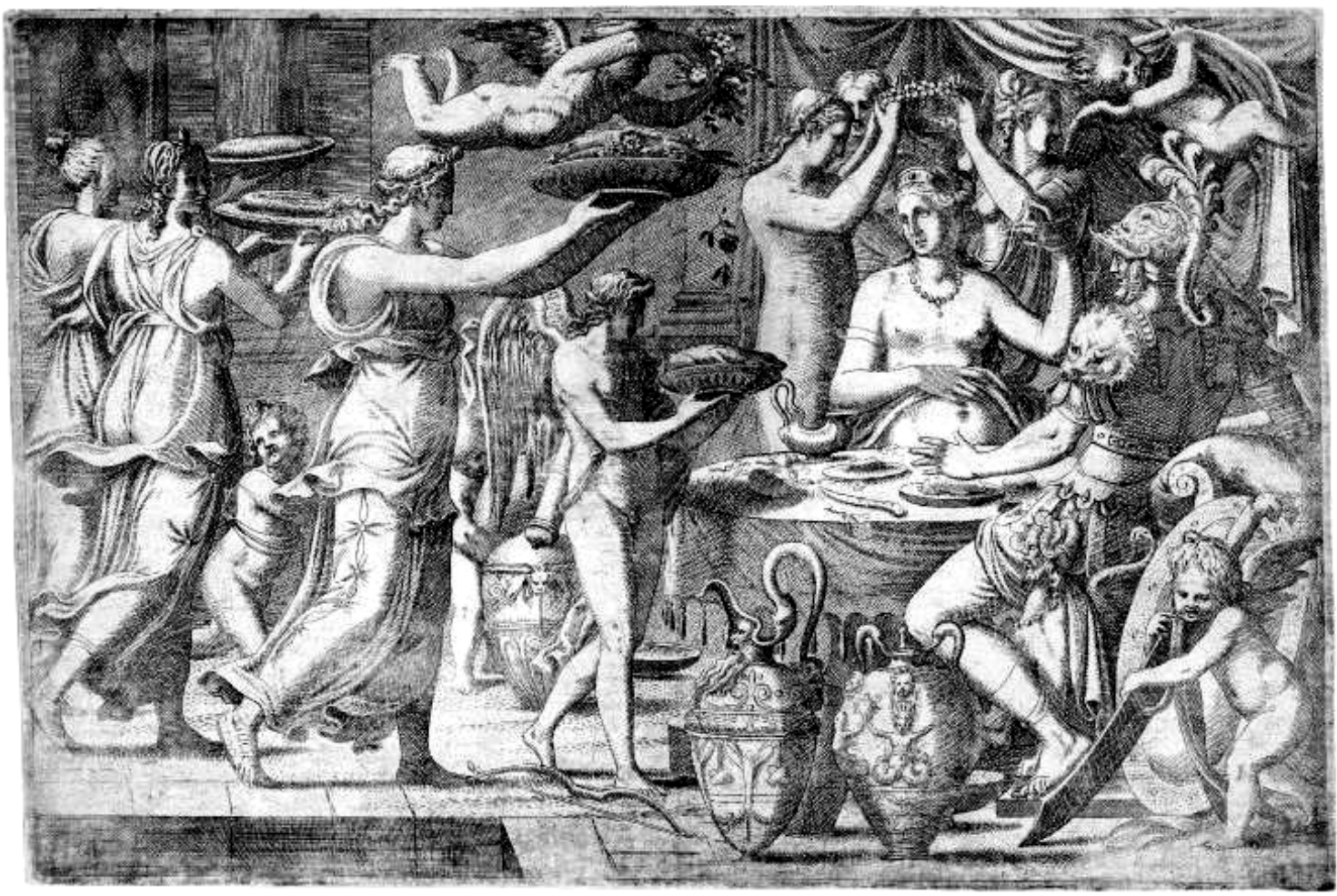

-Léon Davent según Penni. Cupido sirviendo a Marte y Venus. Aguafuerte.1547. 


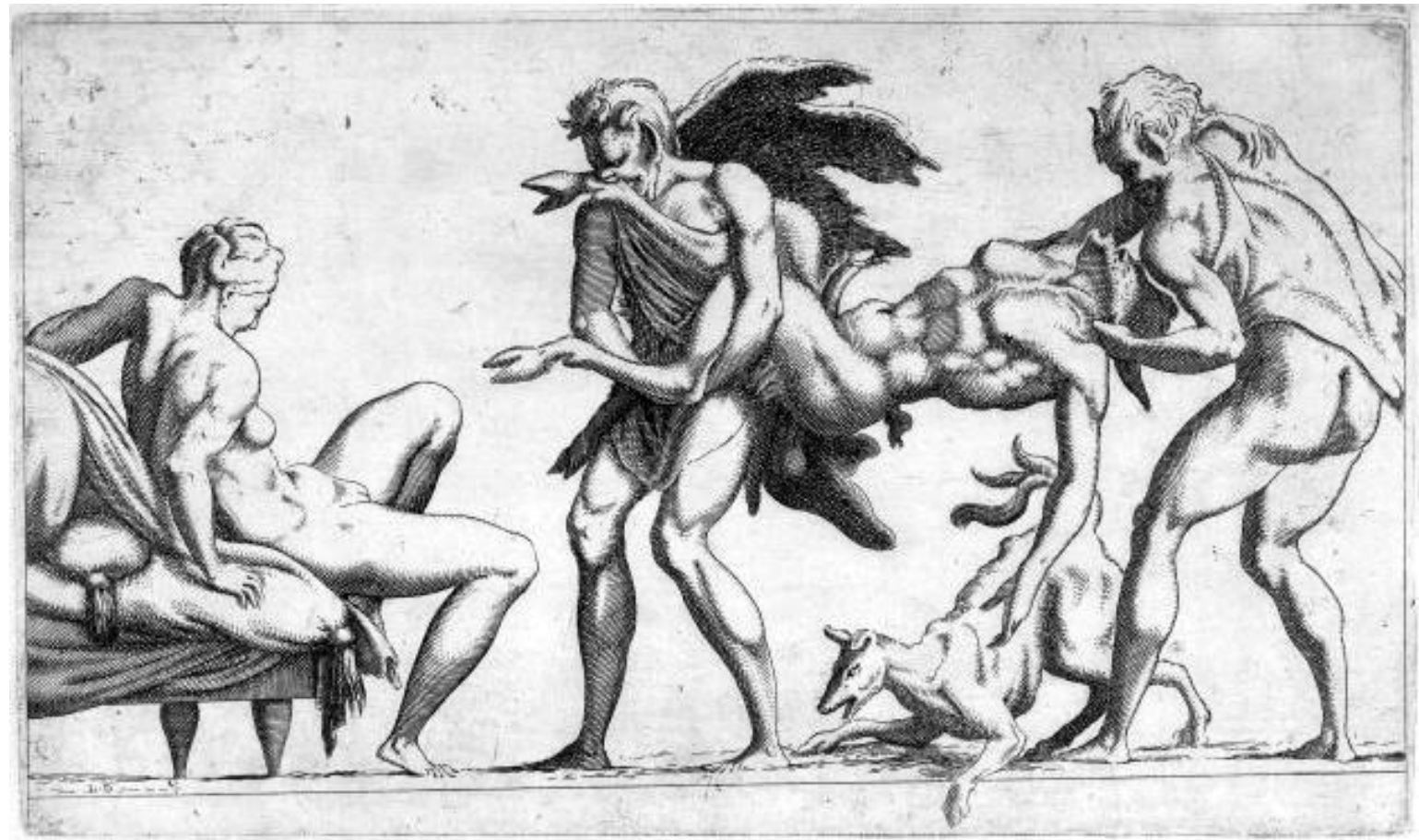

- Léon Davent. Dos sátiros llevándole un fauno a una ninfa. 1547.

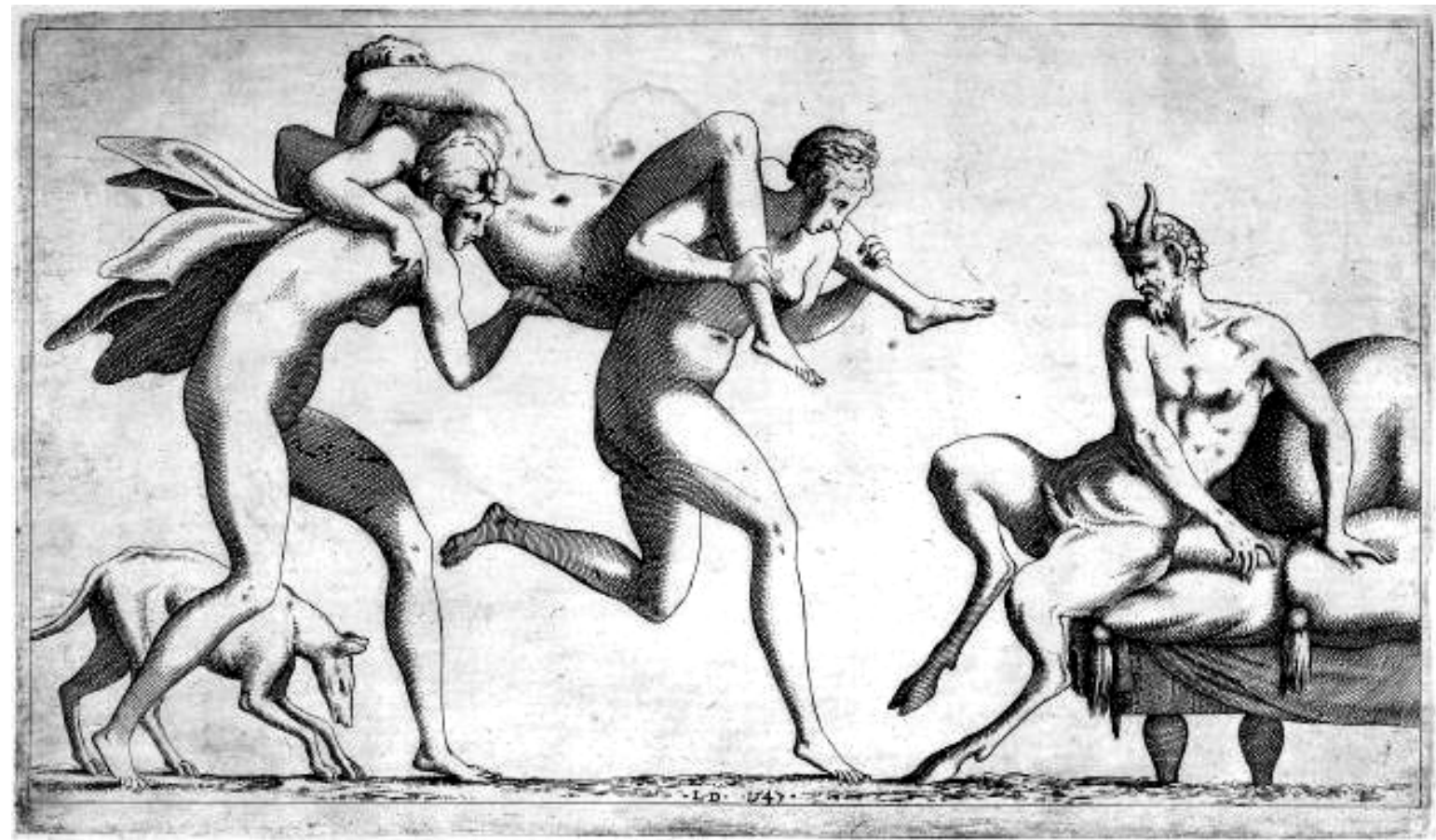

- Léon Davent. Dos ninfas llevándole otra a un fauno. 

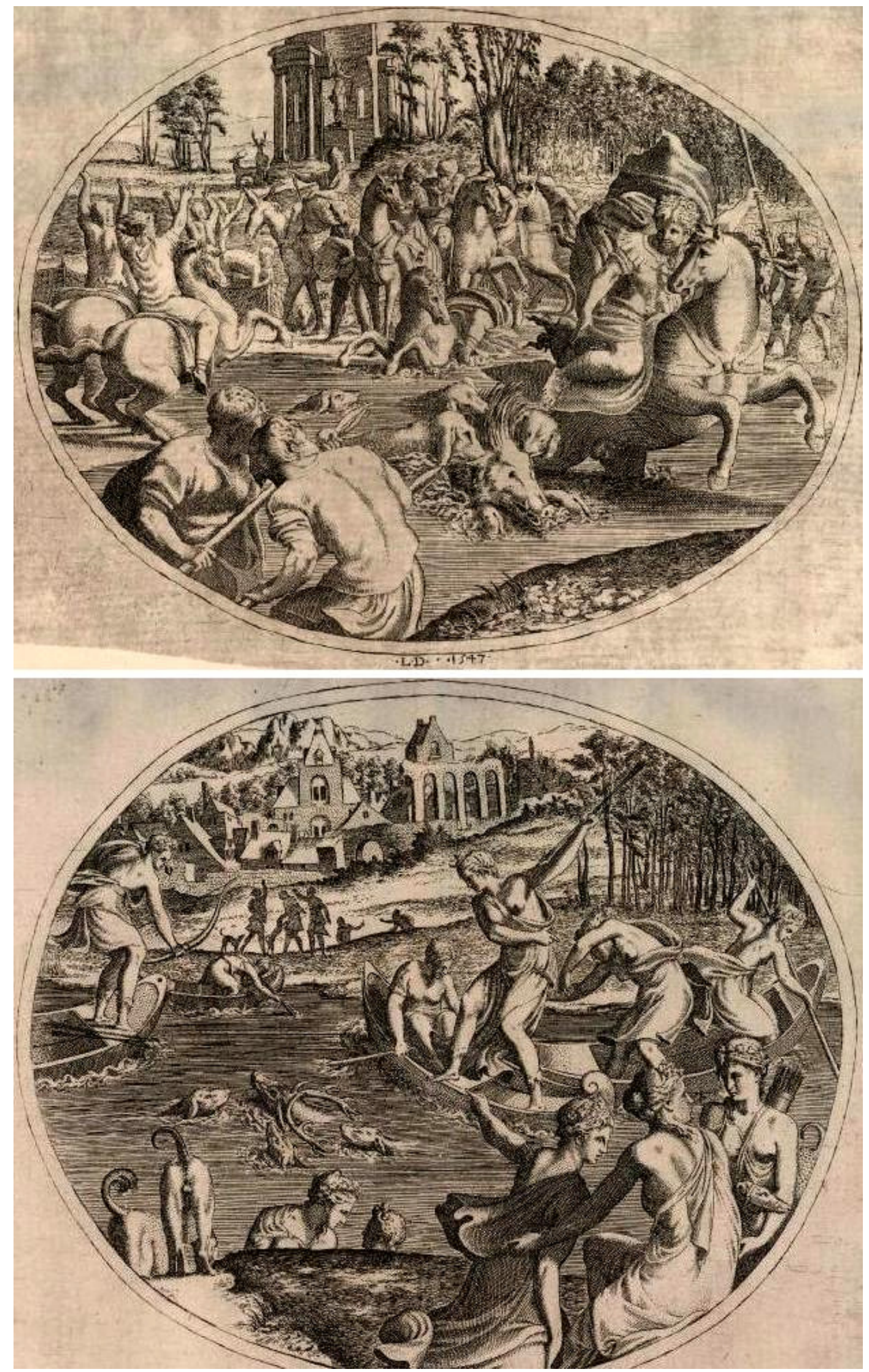

-Léon Davent según Penni o Primaticcio. Escenas de caza. Aguafuertes. 1547. 


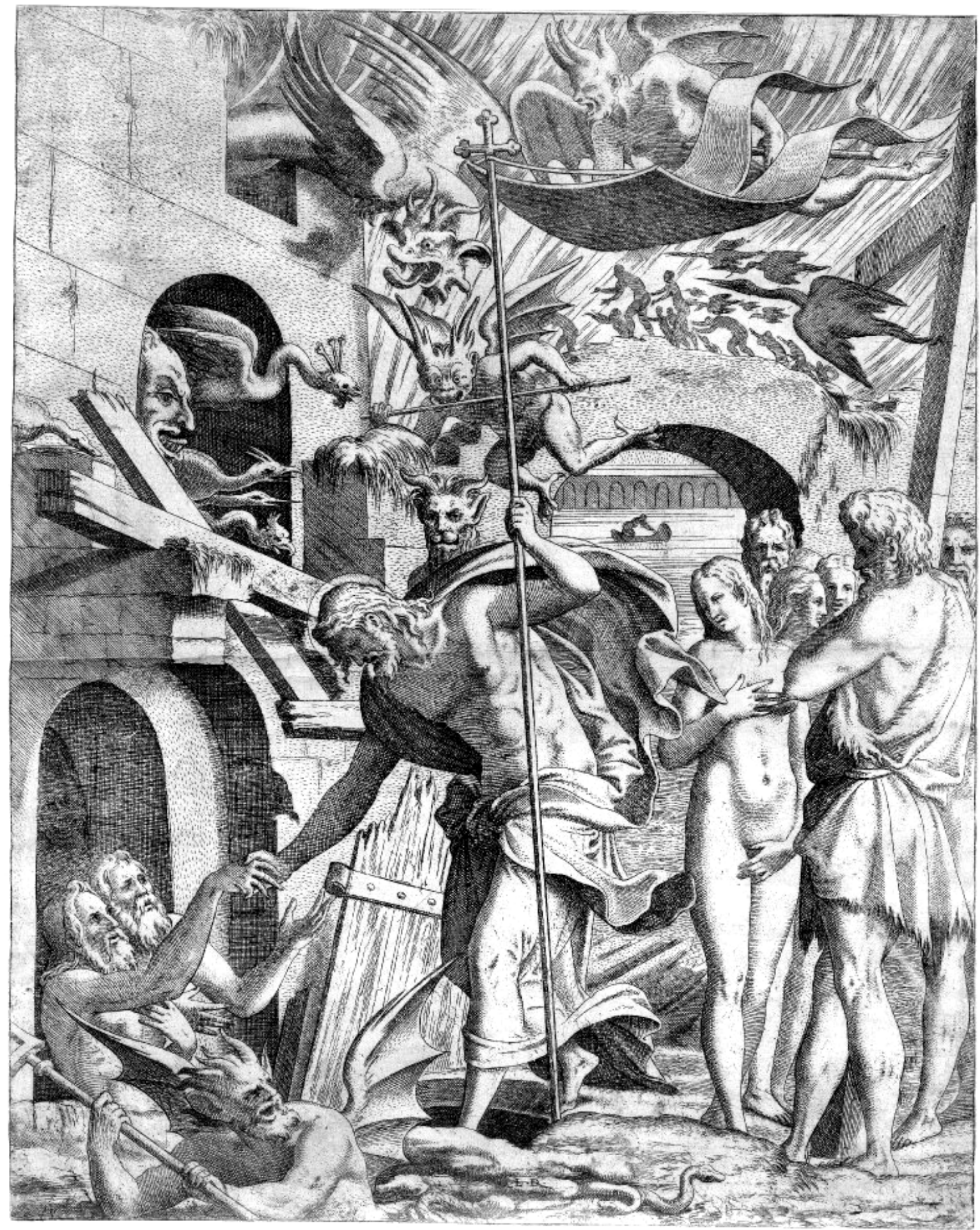

- Léon Davent según Penni o Primaticcio. Descenso de Cristo al Limbo. Aguafuerte.1547. 


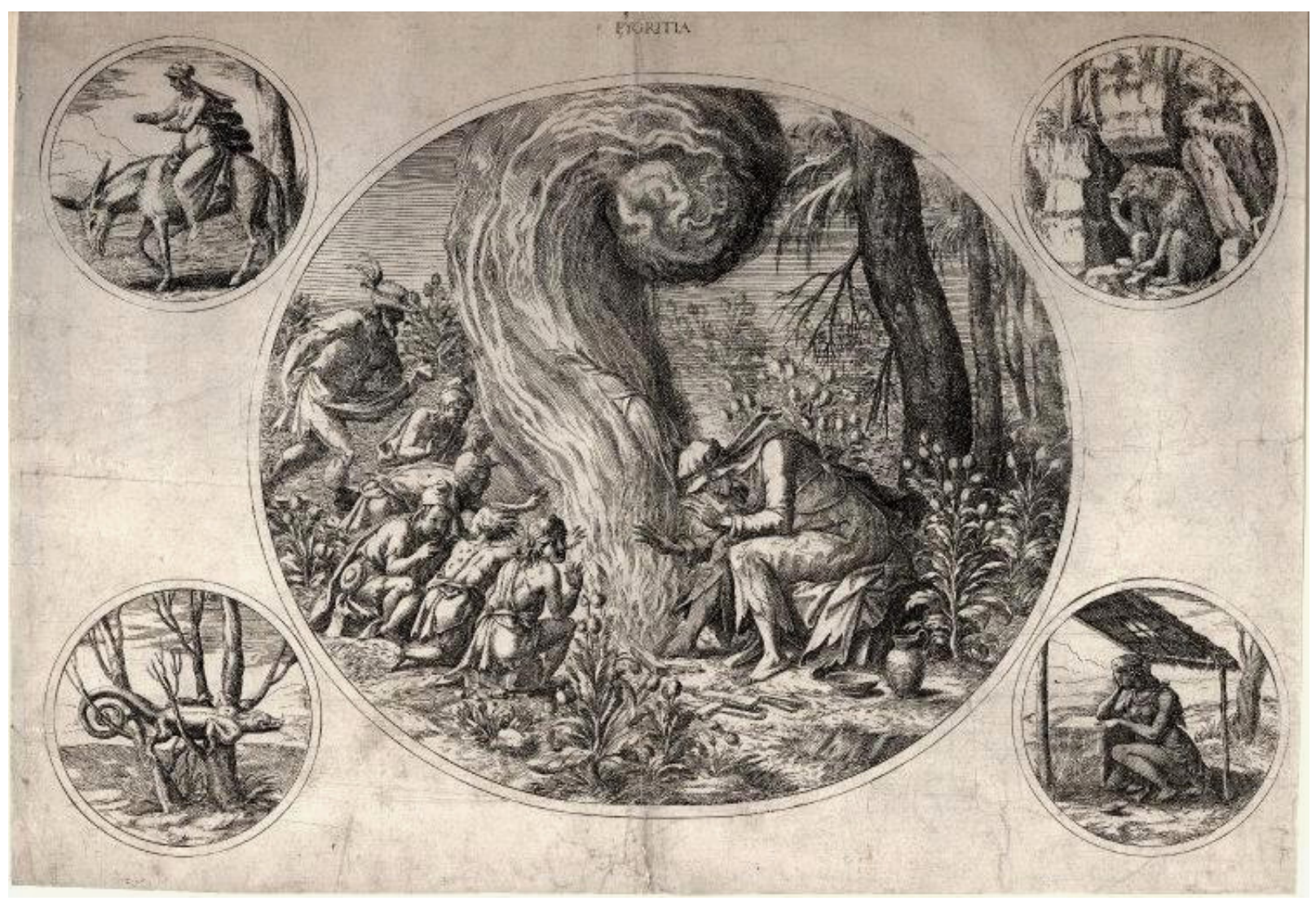

- Léon Davent según Luca Penni. Pereza. Aguafuerte y buril.1547.

De 1547 es la serie de los Pecados Capitales que tiene unas especiales características. Grabada al aguafuerte y al buril en diferentes proporciones según las distintas estampas, consta cada una de ellas de una plancha central ovalada rodeada de cuatro menores de formato circular. Diferencias estilísticas dejan clara la intervención de más de un maestro en su realización.

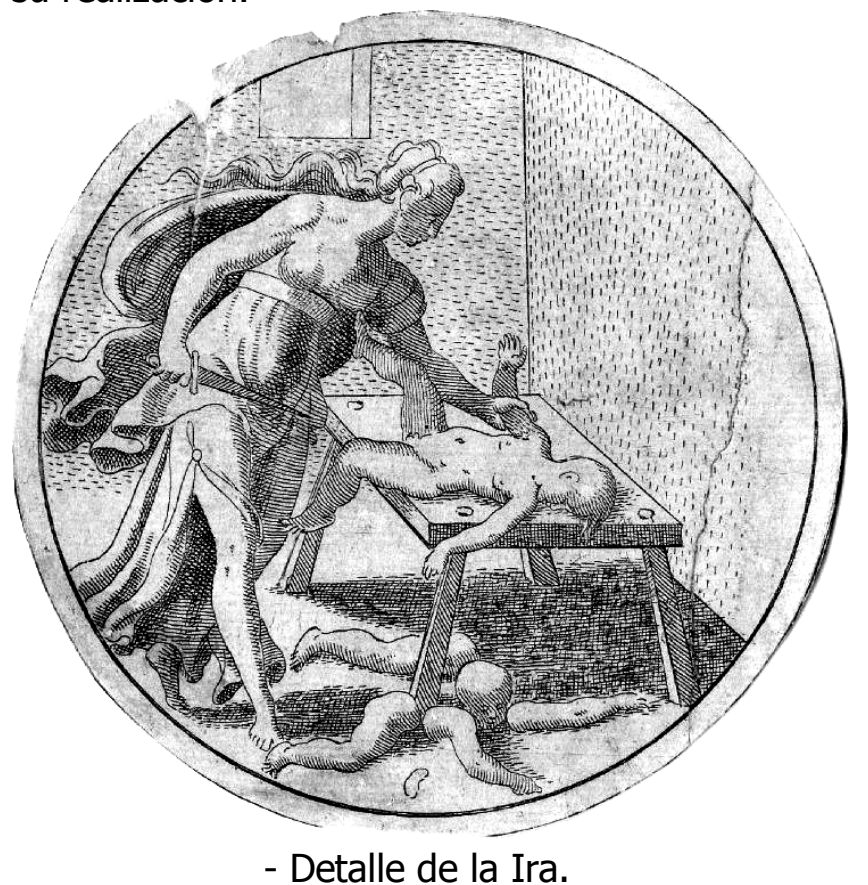



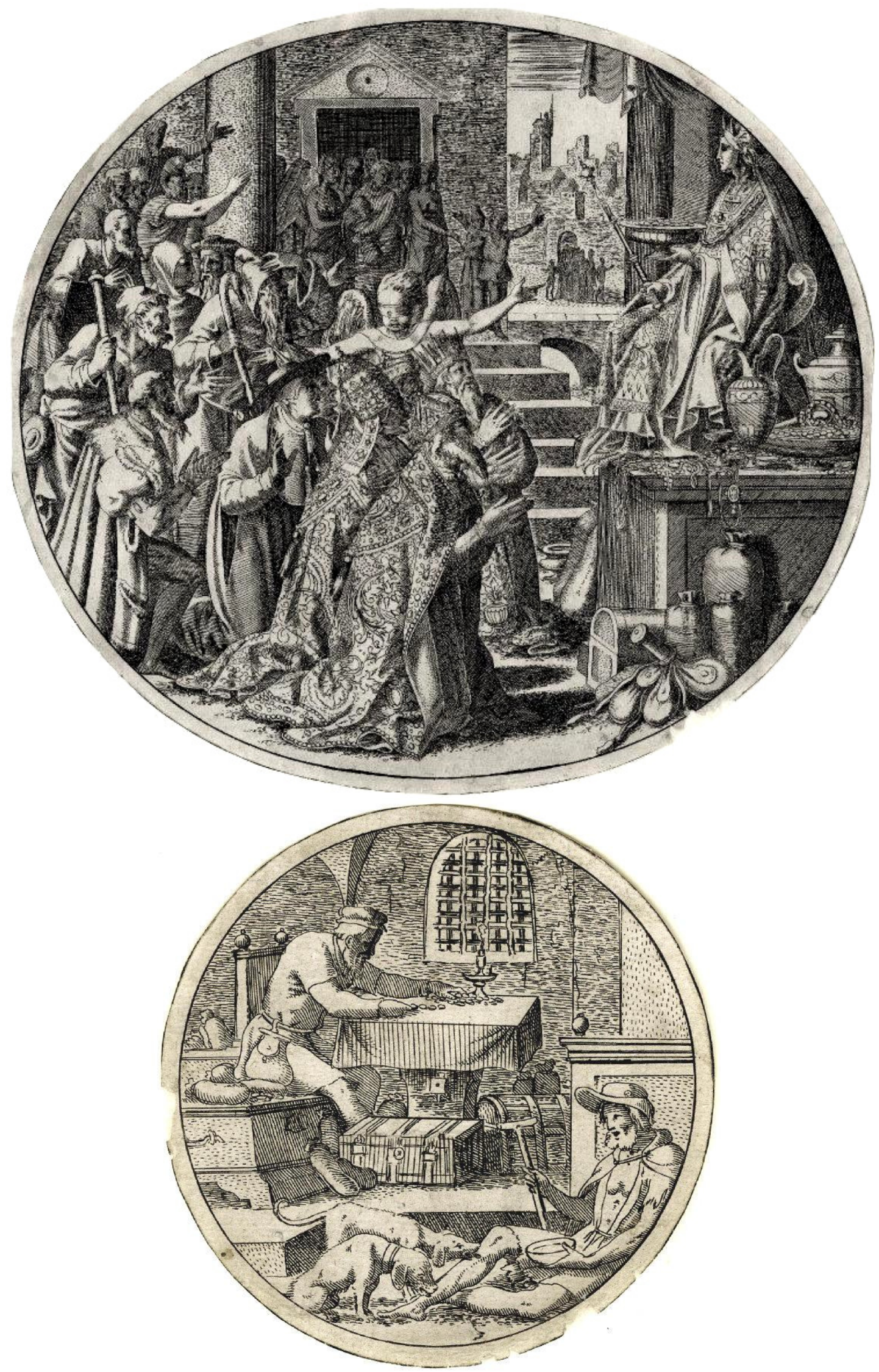

- Léon Davent según Penni. Avaricia, óvalo central y círculo. Detalles. 1547. 